\title{
wotrise
}

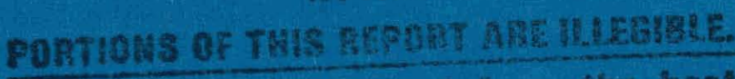

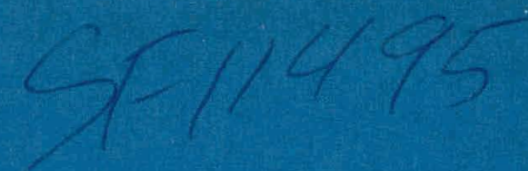

It has baen repioduced from thas hest avaliable cagy tis gerwh the froadest posaible availablity.

it

\section{FORT HOOD SOLAR COGENERATION FACILITY CONCEPTUAL DESIGN STUDY \\ TOPICAL REPORT}

MCDONNELL DOUGLAS ASTRONAUTICS COMPANY

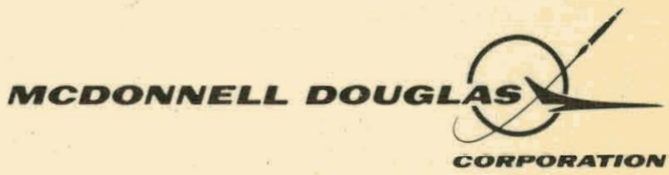




\section{DISCLAIMER}

This report was prepared as an account of work sponsored by an agency of the United States Government. Neither the United States Government nor any agency Thereof, nor any of their employees, makes any warranty, express or implied, or assumes any legal liability or responsibility for the accuracy, completeness, or usefulness of any information, apparatus, product, or process disclosed, or represents that its use would not infringe privately owned rights. Reference herein to any specific commercial product, process, or service by trade name, trademark, manufacturer, or otherwise does not necessarily constitute or imply its endorsement, recommendation, or favoring by the United States Government or any agency thereof. The views and opinions of authors expressed herein do not necessarily state or reflect those of the United States Government or any agency thereof. 


\section{DISCLAIMER}

Portions of this document may be illegible in electronic image products. Images are produced from the best available original document. 


\section{FORT HOOD SOLAR COGENERATION FACILITY CONCEPTUAL DESIGN STUDY \\ TOPICAL REPORT}

APPROVED BY:

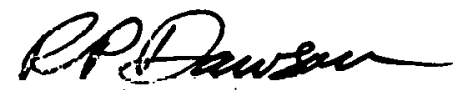

R. P. DAWSON

PROGRAM MANAGER
MDC-G- -9381

DE82 007216

PREPARED FOR: U. S. DEPARTMENT OF ENERGY SAN FRANCISCO OPERATIONS OFFICE 1333 BROADWAY OAKLAND, CA 94612

CONTRACT NO. DE-ACO3-81SF11495

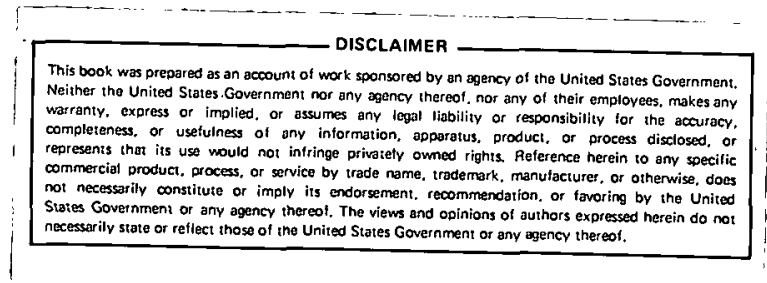




\section{THIS PAGE}

WAS INTENTIONALLY

LEFT BLANK 


\section{PREFACE}

The McDonnel1 Douglas Astronautics Company (MDAC), with the support of the Stearns-Roger Company and the University of Houston Energy Laboratory, has been awarded a nine month study contract by the Department of Energy, San Francisco Office (DOE/SAN), to conduct a conceptual" design study of a solar cogeneration facility at the U.S. Army Fort Hood Base in Killeen, Texas. This project is part of the DOD's program plan to demonstrate the technical, economic, and institutional feasibility of a central receiver solar cogeneration facility in which solar energy is collected and used to provide both high grade energy for the generation of electricity and low grade energy for space heating and cooling, water heating and other useful purposes.

This document constitutes the mid-term Topical Report which contains the following information per DOE instructions:

1. The System Specification as of the date of issue of the Topical Report (refer to Appendix A).

2. Results of tradeoff studies, analysis and system selection from the work of Task 2 (Selection of Site-Specific Configuration).

3. A description of the facility conceptual design which summarizes the efforts to date on Task 3 (Facility Conceptual Design).

4. A table of contents for the Final Technical. Report (refer to Appendix B).

5. A summary of work to the date of submission for Task 4 (Facility Performance Estimates) and Task 5 (Facility Cost Estimates and Economic Analyses).

Requests for further information should be directed to:

McDonnel1 Douglas Astronautics Company 5301 Bolsa Avenue Huntington Beach, CA 92647

- R. P. Dawson, Program Manager, Solar Energy Systems Mail Station 14-3, telephone (714) 896-3080

- D. S. Butler, Manager - Energy Contracts Mail Station 14-1, telephone (714) 896-4821 
THIS PAGE

\section{WAS INTENTIONALLY LEFT BLANK}




\section{Addressee}

1. Department of Energy San Francisco. Operations Office 1333 Braodway

Oakland, CA 94612

Attn: K. A. Rose Solar Energy Division

2. Department of Energy

Division of Solar Technology 600 E. St. NW

Washington, DC 20545

3. Sandia Laboratories Division 8452

Livermore, CA 94550

Attn: J. W. Smith

4. The Aerospace Corporation P.0. Box 92957 Los Angeles, CA 90009
No. of Copies

$4+1$ reproducible 
THIS PAGE

\section{WAS INTENTIONALLY \\ LEFT BLANK}


ACKNOWLEDGEMENTS

The following personnel contributed to this study effort:

DOE/SAN

K. A. Rose - Contracting Officer Representative, Solar Energy Division National Sandia Livermore Laboratory

J. W. Smith - Technical Monitor

J. W. Anderson - Assistant Technical Advisor

MDAC

R. P. Dawson - Program Manager

G. L. Keller - System Analysis

B. E. Tilton - System Performance

W. L. Dreier - Energy Transport and Storage

D. L. Endicott - Equipment Design

G. G. Smith - Controls

Stearns-Roger

W. R. Lang - Subcontractor Coordinator - A\&E Services

W. Stangl - A\&E Design Support

D. Carlson - A\&E Design Support

University of Houston Energy Laboratory

Dr. L. L. Vant-Hull - Subcontractor Coordinator - Field Optimization

Dr. C. L. Laurence - Staff Research Scientist - Field Optimization

DOD/Ft. Hood

0. R. Hill - Fort Hood Project Coordinator 
THIS PAGE

WAS INTENTIONALLY

LEFT BLANK 


\section{ABSTRACT}

In order to reduce our dependence upon non-renewable energy and imported fuels, and to foster the development and commercialization of solar systems; the Department of Energy (DOE) has authorized several studies to demonstrate the technical, economic and institutional feasibility of site-specific central-receiver solar cogeneration facilities, in which solar energy is collected and used to produce both high-grade energy for the generation of electricity and low-grade energy for industrial processes or space conditioning and other useful purposes.

DOE selected the McDonnel1 Douglas Astronautics Company (MDAC) to study the application of a solar cogeneration facility at the U.S. Fort Hood Army Base in Killeen, Texas. MDAC, with the support of the Department of the Army, Stearns-Roger (for A\&E support), and the University of Houston Energy Laboratory (for field optimization support) studied the use of solar-heated molten salt to provide the steam for electricity and for room heating, room cooling, and domestic hot water for Complex 87000 at Fort Hood. The proposed solar cogeneration system will. save the equivalent of approximately 10,500 barrels of fuel oil year year. Development risks are low and, with timely. approvals and appropriate funding, the facility could be operational within threc years. 
THIS PAGE

WAS INTENTIONALLY

LEFT BLANK 


\section{CONTENTS}

Section 1 EXECUTIVE SUMMARY 1

1.1. General Information 1

1.2 Existing Facility Description 3

1.3 Project Summary 6

1.4 Conceptual Design Description 6

1.5 System Performance 14

1.6 Economic Findings ' 18

1.7 Development Plan 18

1.8 Site Owner's Assessment 19

$\begin{array}{lll}\text { Section } 2 \text { INTRODUCTION } & 21\end{array}$

2.1 Study Objective 21

2.2 Technical Approach and Site Selection 22 2.2.1 Approach. 22

2.2.2 Site Selection $\quad 24$

2.3 Site Location $\quad 25$

2.4 Site Geography 26

2.4.1 Site Topography 26

2.4.2 Solar Plant Location. $\quad 29$

2.5 Climate. 30

2.5.1 Solar Insolation 30

2.5.2 Meteorological Data 34

2.6 Existing Plant Description 36

2.6.1 Central Energy Plant 36

2.6.2 Electrical Power Distribution $\quad 37$

2.6.3 Air Conditioning System 38

2.6.4 Room Heating and Domestic Hot
Water Systems

2.7. Existing Plant Performance : $\quad 42$

2.7.1 Energy Demands . 42

2.7.2 Availability/Outages $\quad 44$

2.7.3 Operationand Maintenance 44

2.8 Project Organization 44

2.9 Final Report Organization $\quad 46$

Section $3 \quad$ SELECTION OF PREFERRED SYSTEM . 47

3.1 Introduction 47

3.2 System Configuration 48

3.2.1 Configuration Options 48 
3.2.2 Preferred System Concept 49

3.3 Technology

3.3.1 System Development Risk

Asses sment

3.3.2 Receiver. Fluid Risk Assessment

3.3.3 Receiver Configurations Risk Assessment

3.4 System Sizing 55

3.4.1 Collector Field Sizing 55

3.4.2 System Selection and Sizing 66

3.5 Trade Studies 76

3.5.1 Turbine/Generator Equipment $\quad 76$

3.5.2 High Temperature Storage 80

3.5.3 Low Temperature Storage 83

3.5.4. Air Conditioning Unit 85

3.5.5 Steam Generator 88

3.5.6 Fossil Fueled Heater 91

3.5.7 Control Automation. 95

3.5.8 Solar Equipment Location 100

$\begin{array}{lll}\text { Section } 4 & \text { CONCEPTUAL DESIGN } & 103\end{array}$

Section $5 \cdot$ SUBSYSTEM CHARACTERISTICS 105

$\begin{array}{lll}\text { Section } 6 & \text { ECONOMIC ANALYSES } & 107\end{array}$

$\begin{array}{lll}\text { Section } 7 & \text { DEVELOPMENT PLAN } & 109\end{array}$

$\begin{array}{lll}\text { Section } 8 & \text { USER'S ASSESSMENT }\end{array}$

Appendix A SYSTEM SPECIFICATION

Appendix B FINAL REPORT OUTLINE 117

Appendix C FORT HOOD COMPLEX 87000 THERMAL ENERGY DEMAND CHARACTERISTICS 


\section{References}

1. Department of the Army letter to Mr. R. L. Johnson, President, McDonnell Douglas Astronautics Co., from Col. R. E. Petty IV, Colonel CE, Facilities Engineer; 25 March 1980

2. Department of the Army letter to Dr. H. S. Coleman, Director, Division of Central Solar Technology, U. S. Department of Energy, Washington, DC from C. D. Smith, Deputy Director for Technology and Engineering, Directorate of Military Programs; 13 July 1979

3. Solar Energy Programs for U. S. Army Installations. American Technological University, Phase I Report (4 volumes); 31 March 1975

4. ATU/Fort Hood Solar Total Energy Project. American Technological University, Troop Housing Complex Selection and Installation Site, AL0/3878-77/02; January 1977

5. ATU/Fort Hood Solar Total Energy Program. American Technological University, Phase III Preliminary Design, AL0/3878-77/04; March 1977

6. ATU/Fort Hood Solar Total Energy Project. American Technological University, Phase II Final Report ORO/4924-76/01; April 1977

7. Fort Hood Solar Total Energy Project. American Technological University, Final Report ALO/4231/09-1, 4 volumes; January 1979

8. Solar Total Energy - Large Scale Experiment, Phase II, Fort Hood, Texás, Final Technical Progress Report, Westinghouse Electric Corp., Sept. 1977 (Contract EG-77-C-04-3988)

9. Contract No. 955117 - Program Changes. Jet Propulsion Laboratory letler. to McDonnell Douglas Astronautics Company, 622-ECR:vs; 3 April 1979

10. DOE Solar Central Receiver Program. DOE RFP, Conceptual Design of a Solar Cogeneration Facility, DE-RP03-79SF 10768, Enclosure VIII, Attachment 1; February 1980

11. Cogeneration Program, Semi-annual Review, DOE/SAN, R. W. Hughey, 6 Nov 1980

12. "Input Data for Solar Systems" by V. Cinquemani, J. R. Owenby, J. R. Baldwin, prepared for U. S. Department of Energy, Assistant Secretary for Energy Technology, Division of Solar Technology, Environmental Resources and Assessments Branch under Interagency Agreement No. E (49-26)-1041, March 1980

13. ATU/Solar Energy Program for U. S. Army Installations. American Technological University; Phase I Report, Vol. II - "Availability of Solar Energy at Fort Hood,: AER74-17139 A01, March 1975 
14. "The Effects of Regional Insolation Differences upon Advanced Solar Thermal Electric Power Plant Performance and Energy Costs," prepared by Jet Propulsion Laboratory; DOE/JPL-1060-17, March 15, 1979

15. "Climatography of the United States No. 20-41, Climatological Summary killeen, Texas."

16. "Climatography of the United States No. 90, Climatological Summary Waco, Texas."

17. Detailed drawing "Fort Hood, Texas, EM Barracks Complex, East Site, Layout and Paving Plan, Part II, Corps of Engineers, DACA-63-73-B-0063, November 1972

18. "A Programmer's Manual for the University of Houston Computer Code RCELL: Cellwise Optimization for the Solar Central Receiver. Project." F. W. Lipps and L. L. Vant-Hul1, September 1980.

19. "A User Manual for the University of Houston Solar Central Receiver Cellwise Performance Model - NS," F. W. Lipps and L. L. Vant-Hull, December 1980

20. "Second Generation Detail Design Report;" MDC G8631, August 1980.

21. Ho11, Dr. R. J. Definition of Two Sma11 Central Receivers; McDonnel1 Douglas Astronautics Co. contract AT (929-1)-789; Sand 78-7001, UC 62; Apri 11978

22. Holl, Dr. R. J. A Central Receiver Solar Power System for Remote Locations. McDonnel1. Douglas Astronautics.Co., presented to International Symposium, Workshop on Solar Energy Cairo, Egypt; 20 June 1978

23. Phase 1 of the First Small Power Systeml Experiment (Engineering Experiment No. 1). Fina'l Techrical Report. MeDonne11 Douglas Astronautics Co. Report MDC G7833 (5 volumes); May 1979, submitted to DOE/JPL under Contract No. 955117.

24. A Solar Power Plan for Australia. McDonnell Douglas Astronautics Co.; August 1979 - Revised November 1979

25. The Solar Power Tower in Egypt, McDonnell Douglas Astronautics Co.; October 1979

26. Dawson, R. P., and Holl, Dr. R. J. A Mult purpose Solar Tower Plant, McDonnell Douglas Astronautics Co., presented at the Energy Systems Exhibition, U: S. Trade Center, Sao Paúlo, Brazil; 6 November 1979.

27. Holl, Dr. R. J. A Solar Thermal Electric Power Plant for Small Communities, McDonnell Douglas Astronautics Co., ASME Paper 79-WA/So7-7, presented at the ASME Winter Annual Meeting, New York, N. Y.; 3 December 1979 
Section 1.0

EXECUTIVE SUMMARY

This section contains an overview of the Fort Hood Solar Cogeneration Conceptual Design Study conducted to date by the McDonnell Douglas Astronautics Company for the Department of Energy, San Francisco Office, under Contract No. DE-AC03-81SF11495. This overview, which covers the work performed during the first five months of the nine-month contract, will be updated for the final report.

\subsection{GENERAL INFORMATION}

In support of the National Energy Act of 1978, the Department of Energy (DOE) authorized a number of conceptual design studies of central receiver solar cogeneration facilities. These projects are part of the DOE's total energy program to demonstrate the technical, economic, and institutional feasibility of central receiver solar cogeneration facilities in which solar energy is collected and used to provide both high-grade energy for the generation of electricity and low-grade energy for space heating and cooling, water heating and other useful purposes.

As a result of these DOE plans, the McDonne11 Douglas Astronautics Company (MDAC), with the support of the Stearns-Roger Company and the University of Houston Energy Laboratory, was awarded a nine-month study by the DOE to design and evaluate a solar cogeneration facility at the Fort Hood Army Base in Killeen, Texas. A photograph of the specific site with an artist's rendition of the solar facility installation is shown on Figure 1.1-1.

The primary objective of this solar cogeneration facility study was to provide DOE with site-specific conceptual design data including facility performance, development plans, costs, economics and other related information. The scope of this effort included the preparation of a system specification (Task 1), selection of a site-specific configuration (Task 2), facility conceptual design (Task 3), facility performance estimates (Task 4), cost estimates and 


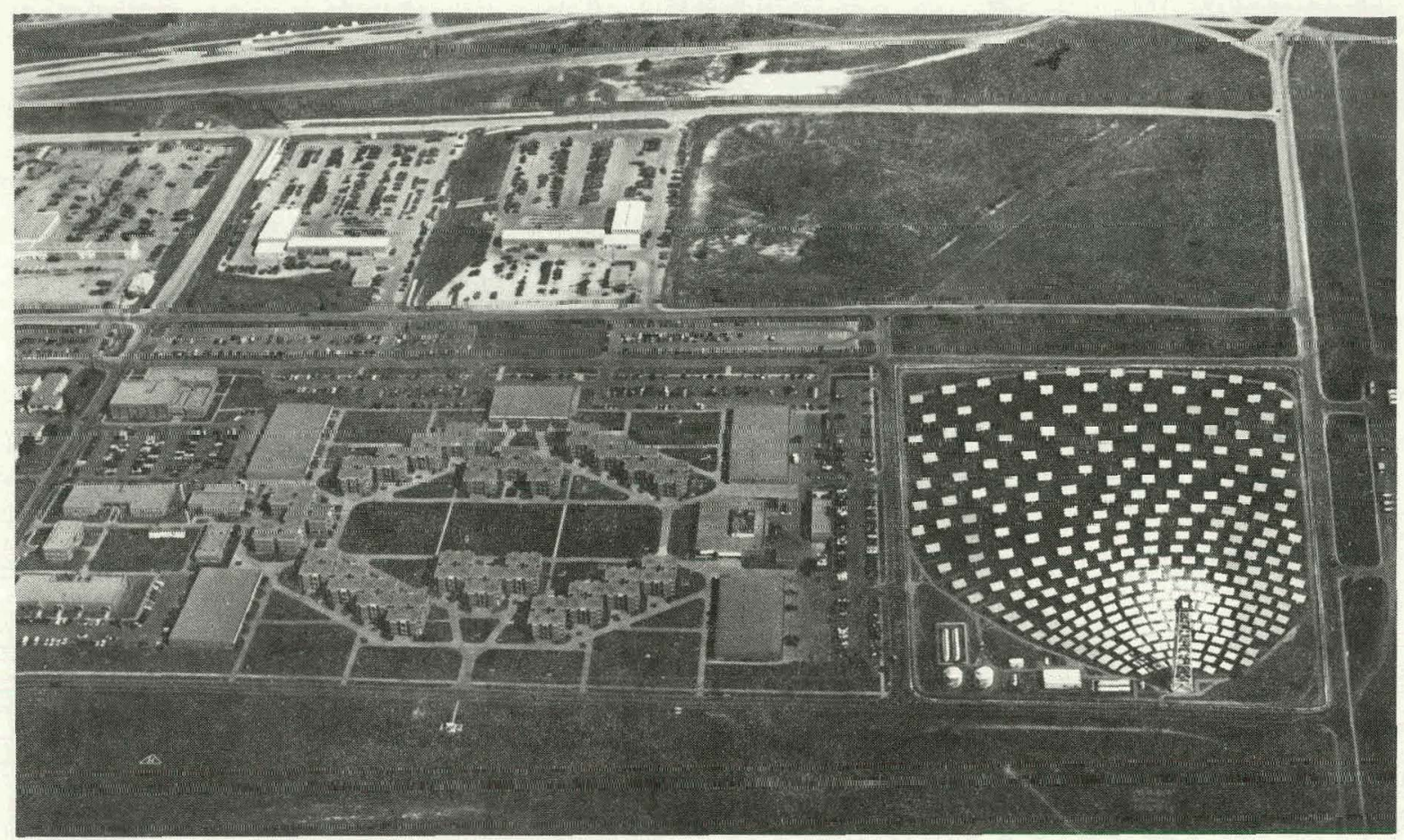

Figure 1.1-1. Fort Hood Solar Cogeneration Facility Installation

economic analyses (Task 5), a development plan (Task 6), and related program management efforts (Task 7). There were no requirements for hardware development on testing during the contract phase.

These tasks were further defined, organized and scheduled, and responsibilities were assigned. The McDonnell Douglas Astronautics Company (MDAC) was the prime contractor responsible for overall contract performance. The Stearns-Roger Company, Denver, Colorado, with extensive experience in related A\&E efforts, was responsible for defining plant support equipment, facility modifications and support in costing, development planning, and the preparation of the System Specification. The University of Houston Energy Laboratory, Houston, Texas, provided support for the collector field optimization efforts.

Fort Hood personnel in the Directorate of Facilities Engineering also contributed significantly to this study effort by providing access to and clarification of data on Fort Hood facilities and operations, and by providing liaison, coordination and participation in numerous reviews. The U. S. Army Corps of Engineers also provided useful information and participated in several program reviews. The Army is committed to the development of solar energy systems at Fort Hood, and has encouraged the installation of such a solar central receiver system at their Complex 87000 . Army documentation 
supporting their interest in this project is given in References 1 and 2. Previous solar cogeneration system studies have been supported by the Army at Fort Hood (References 3 through 8 ). The Energy Resource Office of the Governor of Texas is also intensely interested in this project and has pledged their support.

The general design approach taken by MDAC in this conceptual design study can be summarized as follows:

- Apply MDAC generic system design to a site-specific application.

- Utilize solar equipment previously qualified by DOE.

- Limit the balance of the system to existing equipment and/or current technology.

- Minimize the impact on base facilities and operations.

- Maximize the use of rejected thermal energy (minimize energy losses).

- Design to meet Complex 87000 toțal requirements as much as possible.

- Incorporate design flexibility for other military base applications.

By applying these design criteria, the MDAC team has identified a site-specific solar cogeneration facility that meets a11 the goals established by DOE for this program.

\subsection{EXISTING FACILITY DESCRIPTION}

Fort Hood, which is one of the largest U. S. Army bases in the world, is located at Killeen, Texas, which is approximately midway between San Antonio and Fort Worth in a region of reasonably good insolation ( $\simeq 5 \mathrm{kWh} / \mathrm{m}^{2} /$ day). The climate consists of temperate, rainy winters and hot, dry summers with average precipitation of 30 inches per year. The terrain is reasonably flat and well suited for a central receiver type solar system. Complex 87000 , which is located at the eastern edge of the base, was selected for the solar 
cogeneration installation. Complex 87000 consists of a group of 20 buildings $\left(450,633 \mathrm{ft}^{2}\right.$ of total floor area) of contemporary Army design providing housing, food services, administration, dispensary, PX, storage, recreation and central energy for a brigade-size complement of troops (approximately 1650). A photograph of this complex is shown on Figure 1.1-1. This complex is representative of many similar barracks complexes on this and other military bases.

Fort Hood was selected for a solar cogeneration facility primarily because (1) Fort Hood has a very high annual consumption of electricity and fuel (natural gas); (2) several studies for solar installations at Fort Hood have been conducted in cooperation with the Army since 1974 and considerable technical information is available (References 3 through 8); and (3) a small solar central receiver system at Fort Hood was suggested by DOE/JPL when the contract of the MDAC team on Phase I of the first small power system experiment was terminated (Reference 9) and in the RFP (Reference 10). Accordingly, MDAC conducted a significant company-sponsored study of this application prior to contract award.

Within Fort Hood, Complex 87000 was selected for the solar cogeneration installation because (1) it is representative of concentrated usage of thermal energy for space conditioning and hot water; (2) it offered the greatest flexibility for collector field location; and (3) considerable technical information was available from previous solar studies at this complex.

At Complex 87000, al1 thermal energy needs are provided from a central enerqy plant (Building 87018) located at the eastern edge of the complex, as identified on Figure 1.2-1. Electricity, which is provided by the Texas Power and Light Co., enters the complex at several points and is distributed underground to the buildings of the complex. Also, the power is used to operate two electrical compressors in the central energy plant which produce and distribute chilled water by underground lines throughout the complex for air conditioning in the summer months. Gas, which is provided by the Lone Star Gas Co., is used to operate two steam boilers in the central energy plant which produce and distribute steam by underground lines throughout the complex for year around water heating and room heating in the winter months. 


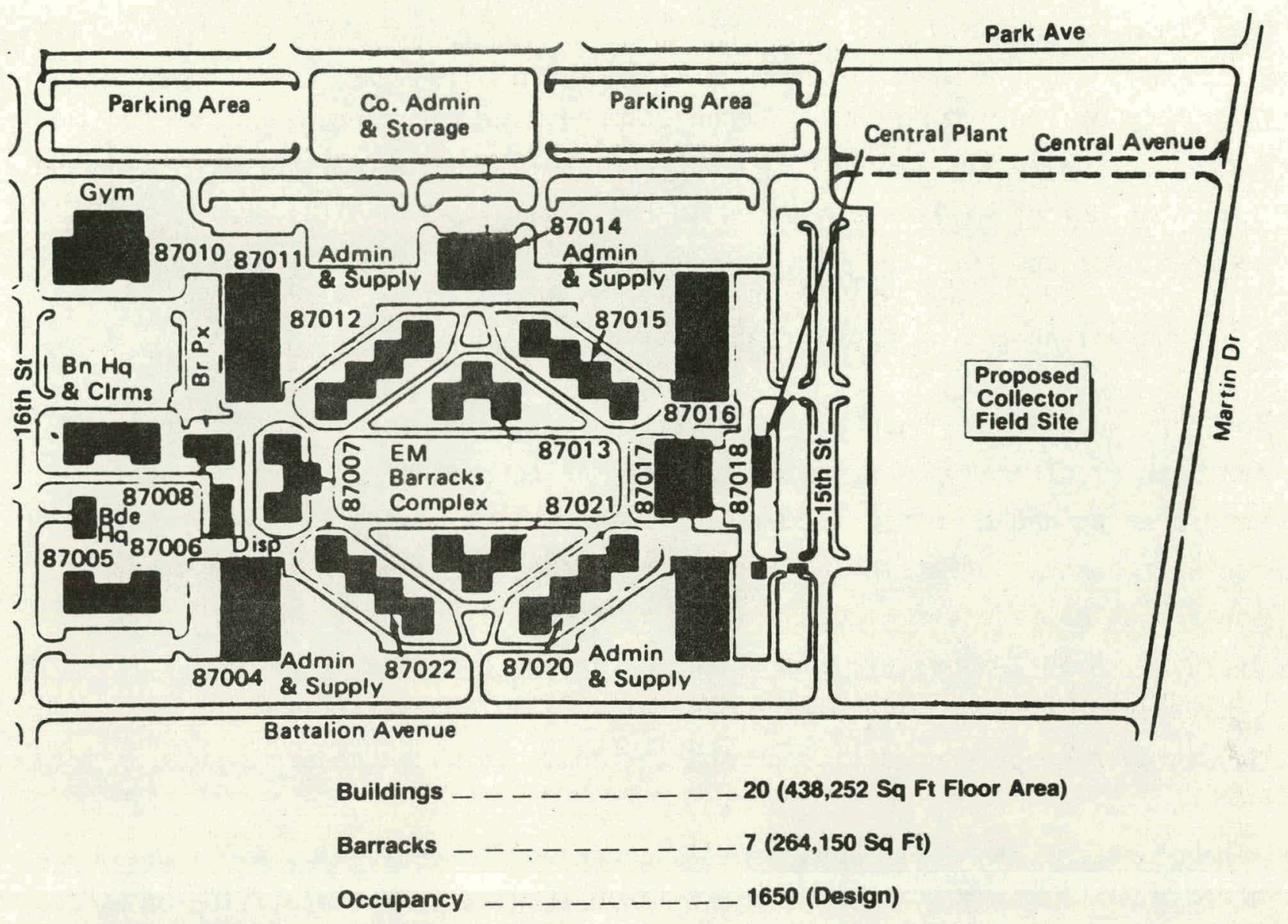

Figure 1.2-1. Fort Hood Complex 87000

The solar equipment and collector field will be located adjacent to the central energy plant in the open field to the east of the complex, as illustrated on Figures 1.1-1 and 1.2-1. A11 interfaces between the solar equipment and the complex will be made at the central energy building. No modifications are needed to any of the energy equipment or distribution network downstream of the central energy plant.

The area selected for the solar equipment is the 15-acre field immediately east of the complex, bounded by 15th Street, Battalion Avenue, Martin Drive and the planned extension of Central Avenue. A small parking lot and park in this area would require relocation. Site development for the solar cogeneration facility will include minor grading, drainage provisions, and the installation of solar equipment, underground pipe/cableways, service roads, parking areas, walkways, and basic utilities (water, gas, power, communications). 


\subsection{PROJECT SUMMARY}

A summary of the programmatic, technical and economic conclusions of the conceptual design study cannot be appropriately made at this time (mid-term). Such conclusions will be presented in the Final Report at the end of the contract period.

\subsection{CONCEPTUAL DESIGN DESCRIPTION}

The Fort Hood solar cogeneration facility is a total energy system designed for both electrical power production and the generation of heat for space conditioning and domestic hot water. The baseline design is a solar central receiver concept utilizing a field of heliostats located to the north of a tower-mounted receiver. Cogeneration is accomplished by generating highpressure, high-temperature steam, and expanding the steam through a turbinegenerator to produce electricity, and utilizing the heat that would otherwise be wasted for space conditioning and the domestic water heating.

A schematic of the solar equipment is shown on Figure 1.4-1. As illustrated on this figure, a field of heliostats concentrates solar insolation on a partial cavity tower-mounted receiver. To absorb the heat, a heat-transfer salt (HITEC) is pumped through the receiver and routed to storage tanks. The stored heat is then transferred to a water-steam loop via a steam generator producing super-heated steam. The steam is expanded through a conventional steam rankine axial turbine which drives a generator producing electricity. Turbine exhaust steam is used to provide room heating, air conditioning, and hot water for the Army complex. Appropriate thermal storage tanks are used to provide the necessary steam and chilled water to the complex for nighttime operation. During periods of low insolation or startup periods, the plant is capable of accepting thermal energy from the auxiliary gas fueled heater. If the solar plant is non-operational for reasons of maintenance or other reasons, the energy demand of the complex can be provided by the existing equipment in the usual manner. Major characteristics of the solar cogeneration facility are summarized on Table 1.4-1. 


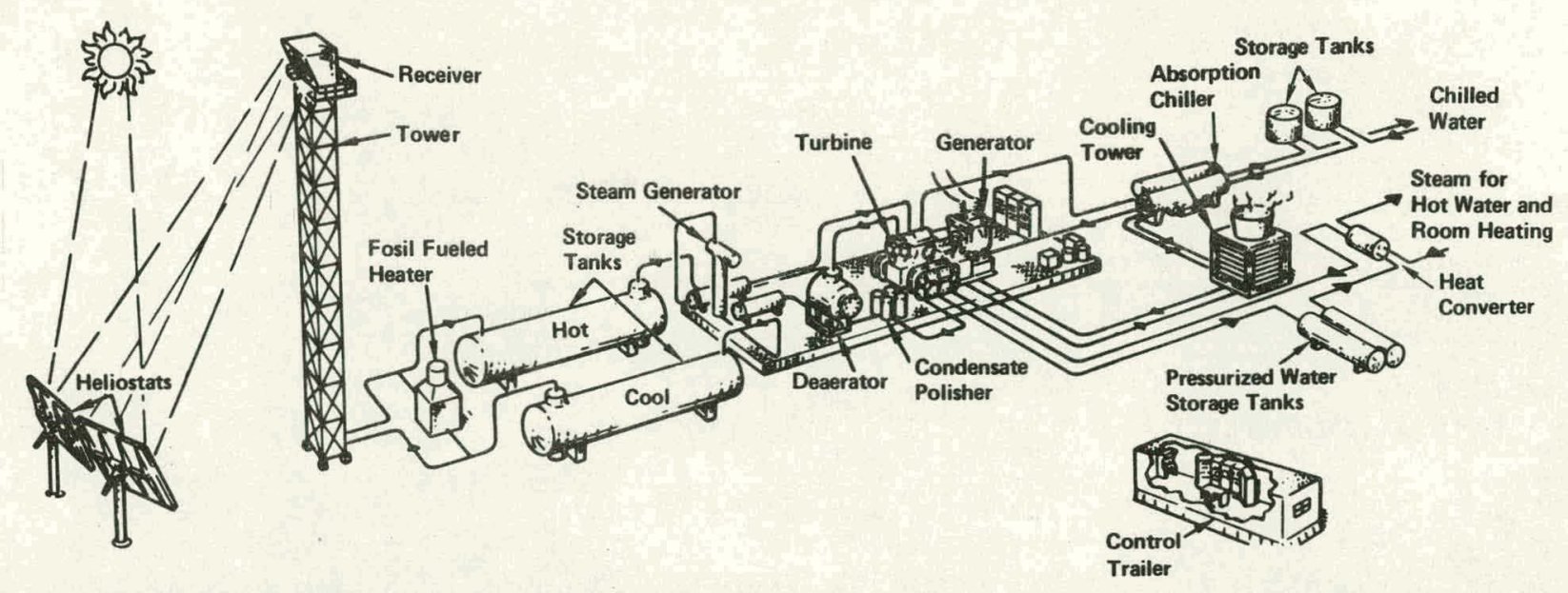

Figure 1.4-1. Solar Cogeneration Facility Arrangement

Table 1.4-1

CONCEPTUAL DESIGN SUMMARY TABLE

Fort Hood Solar Cogeneration Facility

As of May 1981

1. Prime Contractor

2. Major Subcontractors:

3. Site Location

4. Facility Characteristics:
a. Turbine type
b. Turbine inlet
c. Turbine outlet
d. Process fluid
e. Temperature/pressure

McDonnell Douglas Astronautics Co. Huntington Beach, CA

(Project Manager - R. P. Dawson)

Stearns-Roger, Denver, C0

(Project Coordinator - W. R. Lang)

University of Houston Energy Laboratory Houston, TX

(Project Coordinator - Ur. L. L. Vant-Hu11)

Fort Hood Army Base

Killeen, TX

Steam Rankine, Trane Model TMG (600 kW)

$399^{\circ} \mathrm{C}\left(750^{\circ} \mathrm{F}\right), 49 \mathrm{Bar}(715 \mathrm{psia})$

$148^{\circ} \mathrm{C}\left(289^{\circ} \mathrm{F}\right), 4.5 \mathrm{Bar}(65 \mathrm{psia})$

Water/steam - space conditioning and domestic hot water

$6^{\circ} \mathrm{C}\left(42^{\circ} \mathrm{F}\right)$ chilled water, 30 psia sat. steam 
Table 1.4-1

(Continued)

5. Design Point

Noon, fall equinox

6. Receiver:
a. Fluid
HITEC (molten salt)
b. Configuration
Cavity cone
c. Type
Once-through
d. Elements
Absorber, support structure, door, heaters, insulation, piping and manifolds, housing
e. Temperature
f. Pressure
$454^{\circ} \mathrm{C}\left(850^{\circ} \mathrm{F}\right)$ outlet; $260^{\circ} \mathrm{C}\left(500^{\circ} \mathrm{F}\right)$ inlet
Atmospheric (outlet)

7. Collector Field:
a. Heliostat number
242
b. Mirror area
$56.84 \mathrm{~m}^{2}\left(612 \mathrm{ft}^{2}\right)$ per heliostat
c. Inslalled cost
(TBD) $\$ / \mathrm{m}^{2}$
d. Type
MDAC 2nd Generation
e. Field configuration
North field
f. Total mirror area
$13,755 \mathrm{~m}^{2}\left(148,007 \mathrm{ft}^{2}\right)$
g. Total collector field
$48,000 \mathrm{~m}^{2}$ (11.9 acres)

8. Storage:
a. High-temperature
HITEC, $20 \mathrm{MWh}_{\mathrm{t}}$
b. Iow-temperature
Pressurized water, 5.0 MWh
c. Chilled water
Water, $7.5 \mathrm{MWh}_{\mathrm{t}}$

9. Project Cost:
a. Total (w/o 0\&M)
b. Total (at $\$ 260 / \mathrm{m}^{2}$ )

10. Construction Time 
Table 1.4-1

(Continued)

11. SCF Energy Contribution (Design Point)
a. Receiver output
$8.9 \mathrm{MW}_{\mathrm{t}}$
b. Electrical power
$0.6 \mathrm{MWe}$
c. Mechanical power
Not Applicable
d. Process power
$3.5 \mathrm{MW}_{\mathrm{t}}$

12. SCF Energy Contribution (annual)
a. Receiver output
b. Electrical power
c. Mechanical power
d. Process power

$13,642 \mathrm{MW}_{\mathrm{t}} \mathrm{h}$ (70\% total thermal power demand)

$4,367 \mathrm{MW}_{\mathrm{e}}^{\mathrm{h}}$ (85\% total electrical power demand) Not Applicable

9.321 $\mathrm{MW}_{\mathrm{t}^{\mathrm{h}}}$ (100\% total process power demand)

13. Solar Fraction
a. Design point
0.85
b. Annual
0.45

14. Annual Fossil Energy Saved

10,452 bbl oil

15. Type of Fuel Displaced

Gas, oil

16. Ratio Annual Energy Produced to Total Mirror Area

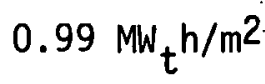

17. Ratio of Capital Cost to Annual Fuel Displaced

(TBD) $\$ / M W h_{t}$

18. Site Insolation (Direct Normal)
a. Design point
$940 \mathrm{~W} / \mathrm{m}^{2}$
b. Annual average
$4.9 \mathrm{MWh} / \mathrm{m}^{2}\left(4.7 \mathrm{MWh} / \mathrm{m}^{2}\right.$ for $\left.\pm 10^{\circ}\right)$
c. Source
Watt model for Waco modified by $\mathrm{U} / \mathrm{H}$ for Fort Hood
d. Site measurements
Not Applicable 
Table $1.4-1$

(Continued)

19. Cogeneration Utilization Efficiency.
a. Useful electrical energy
$4,367 M \mathrm{e}^{\mathrm{h}}$
b. Useful mechanical energy
$0 \quad \mathrm{MWh}_{\mathrm{m}}$
c. Useful thermal energy
$9,321 \mathrm{MW}_{\mathrm{t}^{\mathrm{h}}}$
d. Total energ.y input
19,173 MWh (collected solar plus gas)
e. Overall efficiency
$71 \%$

A11 necessary solar cogeneration equipment is located in the open field adjacent to the central energy plant. All interfaces are at the central energy plant, and no modifications are required to the energy equipment, distribution network., or other buildings on the complex.

The major components and energy/fluid flow paths of the baseline system are illustrated schematically in Figure 1.4-2. Major elements of the cogeneration facility are briefing described below.

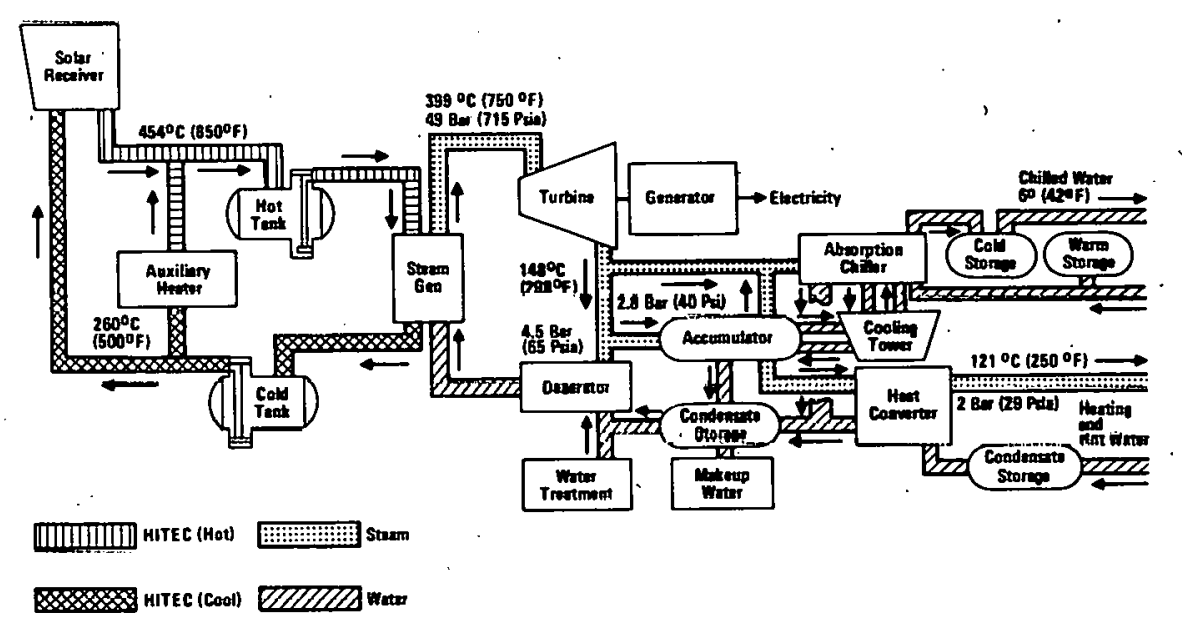

Figure 1.4-2. System Flow Schematic 


\section{Heliostats}

The baseline collector field uses 242 MDAC second-generation heliostats. This heliostat was designed to include the requirements of small field installations, and can be transported to the site in modules. Heliostat controllers calculate the sun's position, direct individual heliostat motions, calculate positioning errors, and direct correction motions.

\section{Receiver}

The receiver provides a means of transferring the incident radiant flux energy from the collector field into a working fluid. The tower-mounted receiver is a partial cavity design with a $5.0 \mathrm{~m}(16.4 \mathrm{ft})$ diameter aperture facing north and tilted downward from vertical. The absorber unit consists of stainless steel tubes in a spiral configuration with the heat transfer fluid entering at the periphery and exiting at the apex of the cone. Insulated doors close over the receiver aperture during periods of no insolation in order to minimize heat loss. Trace heaters keep the working fluid from cooling and solidifying during nighttime.

\section{Receiver Working Fluid}

The receiver working fluid is. HITEC, a molten salt solution composed of $53 \%$ $\mathrm{KNO}_{3}, 7 \% \mathrm{NaNO}_{3}$, and $40 \% \mathrm{NaNO}_{2}$ with a melting temperature of $142^{\circ} \mathrm{C}\left(288^{\circ} \mathrm{F}\right)$ and a maximum operating temperature of $535^{\circ} \mathrm{C}\left(1000^{\circ} \mathrm{F}\right)$. A receiver outlet temperature of $454^{\circ} \mathrm{C}\left(850^{\circ} \mathrm{F}\right)$ was selected for design purposes in order to maintain equipment simplicity, minimize costs and enhance reliability.

\section{Tower}

The tower is a low-cost, free-standing, steel design which supports the receiver and riser and downcomer lines and includes other supporting items. The tower is $54 \mathrm{~m}$ ( $177 \mathrm{ft}$ ) in height and is located at the southern edge of the field in order to permit an optimum arrangement of heliostats in the constrained field. The tower is designed to be transportable as prefabricated sections to the site.

\section{High Temperature Storage Tanks}

Energy storage is provided by two horizontal cylindrical tanks that store hot and cold HITEC. The HITEC that is heated in the receiver is routed to the 
hot storage tank where it is stored for use in generating steam for the electrical generation subsystem. The flow of HITEC to the steam generator, which is independent of receiver flow, shall be regulated by the demand for turbine inlet steam. After passing through the steam generator, the cool HITEC shall be returned to a separate cold storage tank. The storage tanks shall permit the storage of excess thermal energy as sensible heat during periods of high insolation for use in generating electricity during periods of low insolation. For prolonged periods of low or no insolation, an auxiliary fossil-fueled energy subsystem can be used to generate heat for the system. The HITEC storage tanks will be located near the tower and auxiliary heater, and the tanks will be placed in a pit below grade for drainage and salt containment in the event of leakage.

\section{Auxiliary Heater}

A Struthers Wells type auxiliary gas-fired heater will enable plant operation during cloudy days or during periods of excessively high energy demand. HITEC from the cold thermal storage tank can be pumped through the heater and into the hot thermal storage tanks, as required. The heater unit is pre-assembled and skid mounted for minimum site assembly.

\section{Steam Generator}

The steam generator is a Struthers Wells kettlc-type reboiler system, which consict.s of a preheater, vaporizer boiler and superheater. Using heated HITEC from the hot storage tank, the steam generator produces $2 \mathrm{~kg} / \mathrm{sec}$ $(j 6,400 \mathrm{lb} / \mathrm{hr})$ of steam at $399^{\circ} \mathrm{C}\left(750^{\circ} \mathrm{F}\right)$ and 49 bar (715 psia) for turbine operation. The flow of HITEC to the steam generator, which is independent of receiver flow, will be regulated by the demand for turbine inlet steam.

\section{Turbine Generator}

The power conversion equipment is a Trane single stage-steam Rankine turbine with a standard Marathon generator that produces a rated power of $600 \mathrm{KW}_{\mathrm{e}}$. The electric power generated is integrated into the existing electrical network for the complex and the base by means of appropriate switches, transformers and controls. The turbine is designed to exhaust steam at a back pressure of $4.5 \mathrm{bar}(65 \mathrm{psia})$ and $148^{\circ} \mathrm{C}\left(298^{\circ} \mathrm{F}\right)$ for the operation of 
a deaerator, absorption chiller and accumulator for low temperature thermal storage. The condensed steam is cooled, treated and reheated for recirculation into the steam generator. All equipment is skid-mounted at the factory with the remaining connections to be made at the site. A single building will house most all of the power generating equipment except the cooling tower and control console.

\section{Absorption Chiller}

The air conditioning unit is an existing Trane two-staged absorption chiller with an output rating of 800 tons. Turbine exhaust steam is used to vaporize and condense a lithium bromide/water solution which, in turn, chills water to $6^{\circ} \mathrm{C}\left(42^{\circ} \mathrm{C}\right)$ for circulation to the complex through existing chilled water lines. Two chilled water storage tanks are included in the loop to provide chilled water for nighttime operations. The absorption chiller is located inside the turbine/generator building, and the storage tanks are located next to this building.

\section{Low Temperature Thermal Storage}

A low temperature thermal storage system has been incorporated to provide steam at 2 bar $(29 \mathrm{psia}), 121^{\circ} \mathrm{C}\left(250^{\circ} \mathrm{F}\right)$ to the complex for domestic water heating and room heating during the nighttime. Turbine exhaust steam is routed through an accumulator where it is condensed and stored under pressure. Upon demand, this pressurized water is converted into steam and passed through a heat exchanger to generate steam in a separate loop for distribution to the complex through the existing steam lines. The accumulator storage tanks are located near the sular turbine/generator building, and the small heat exchanger is located inside the present central energy plant.

\section{Cooling Tower}

The present cooling tower, located adjacent to the central plant, will also be used for the solar r.ngeneration equipment. Thc existing evapurative, mechanically induced draft cooling tower is rated at $11.4 \mathrm{million}$ BTU/hr. Final heat rejection requirements will determine whether it is adequate for the cogeneration facility. Otherwise, a new tower will be constructed near the chilled water tanks. 
Plant Control

A plant control subsystem has been designed to sense, monitor and control all system parameters necessary to ensure safe and proper operation of the entire integrated cogeneration facility. The control and monitoring cover two distinct areas: heliostat field control and plant subsystem control. For heliostat field control, a serial signal communications network provides independent control of all heliostats through the overall plant process controller. For plant subsystem control, remote control units stationed throughout the plant respond to commands from a central control unit which, in turn, is controlled by the plant process controller. The plant process computer permits the integrated operation and coordination of all subsystem processes, either automatically or manually, under the direction of a single plant operator. The plant control subsystem also enables the gathering and processing of plant data. All equipment will be preassembled and checked out in a mobile control trailer at the factory prior to delivery to the site. The control trailer, which is located adjacent to the turbine/generator building, also contains necessary space conditioning equipment and operator conveniences.

\section{Specialized Equipiment}

Some specialized equipment will be needed to service, maintain, repair or overall the elements of the solar cogeneration facility. This equipilient includes a service van, mobtle crume, heliostat washer, checkout/calibration equipment, handling fixtures/slings, work platforms/ladders, and maintenance tools. This equipment will be housed in the turbine/generator building.

\subsection{SYSTEM PERTORMANCE}

'The performance of the Fort Hood solar cogeneration facility is very dependent upon the available insolation at the site, and the efficienries in which this energy is collected and utilized by the system. Annual available direct insolation across the United States is shown on Figure 1.5-1. The average annual insolation at Fort Hood is $4.9 \mathrm{Mw}_{\mathrm{t}} \mathrm{h} / \mathrm{m}^{2}$ per day, which is considered to be sufficient to operate a central receiver type solar system. As noted on the figure, there are other regions that have considerably higher and lower insolation levels. 


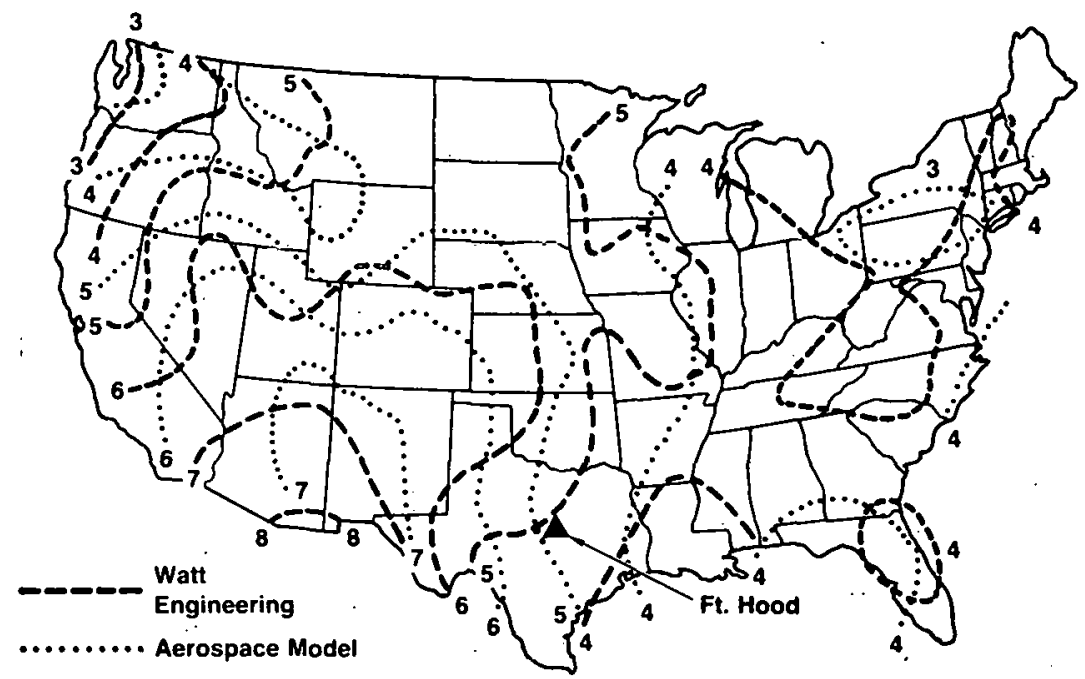

Figure 1.5-1. Direct Normal Isolation (kWh/ $/ \mathrm{M}^{2}$ Day)

The efficiency of the proposed collector system is shown on Figure 1.5-2 for noon on a clear day at the fall equinox. Losses considered have included cosine effects, blocking and shadowing, reflectivity, layout and boundary losses, hellostat availability, attenuation, receiver interception, absorptivity, thermal and piping losses. As indicated, the overall collection efficiency is 0.686 to the bottom of the tower. The efficiencies of the remainder of the cogeneration facility depend upon the energy load demands and the system operating mode at any particular time.

The thermal and electrical load demands of Complex 87000 vary significantly on both an hourly and seasonal basis. Figure 1.5-3 shows typical daily energy requirements for a winter, summer and spring/fall day. As can be noted, electrical loads and thermal loads for domestic hut water are not much affected by the seasons, as would be expected. However, the seasonal variations result in large demands for heating in the winter and air conditioning during the summer. Consequently, the resultant thermal demand profile requires two to three times as much thermal energy during the winter and summer as is needed during the spring and fall. Thus, a solar system sized to match the minimum spring/fall demands will fall far short of meeting the winter/summer needs. Conversely, a system sized for the winter and summer demands will have excessive thermal spillage during the spring/fall months. Optimization studies have indicated that it is cost effective to size the system larger than the minimum demands and spill the excess thermal energy. 


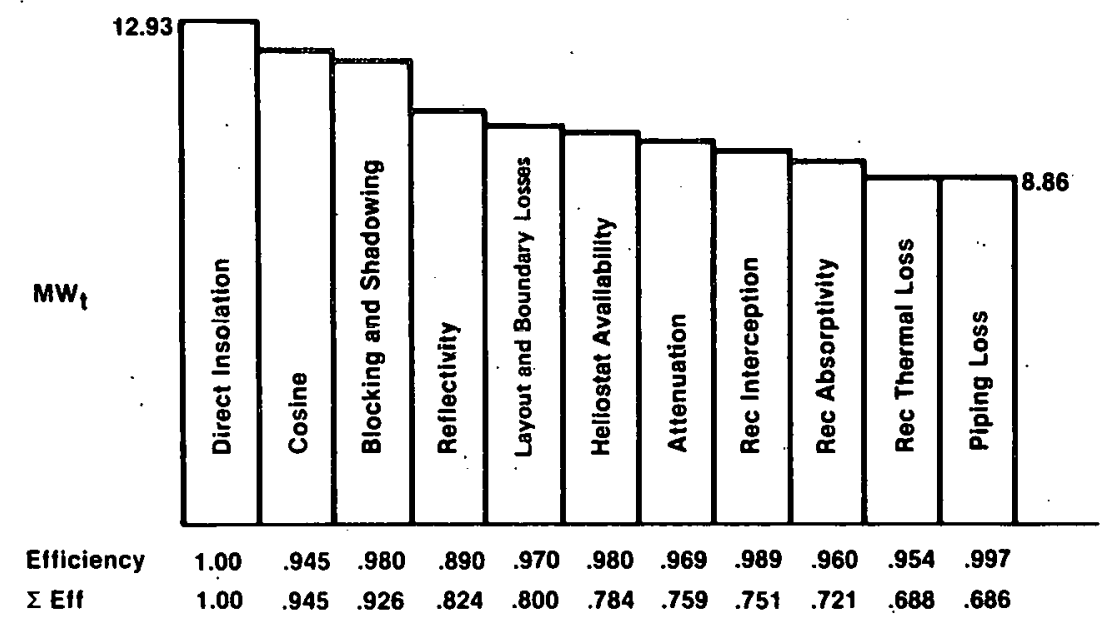

Figure 1.5-2. Performance Summary - Design Point (Fall Equinox - Noon)

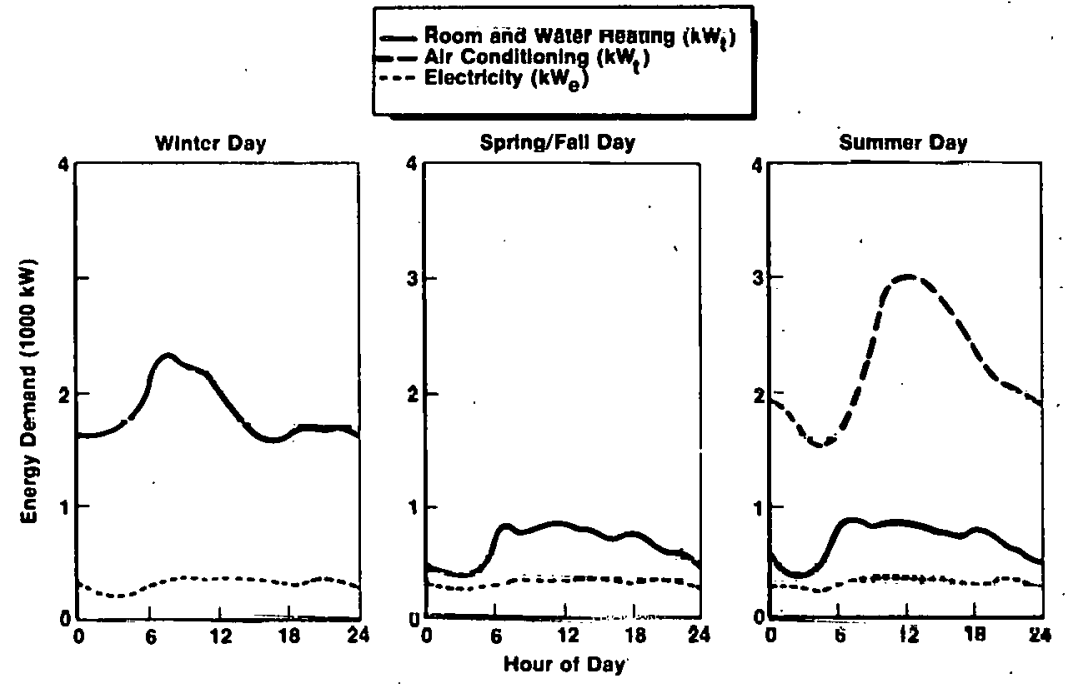

Figure 1.5-3. Typical Daily Demand Requirements at Complex $\mathbf{8 7 0 0 0}$

A summary of the monthly energy demands, and the capabilities of the proposed solar cogeneration facility to meet these demands, are summarized on Figure 1.5-4. These resulls are based on the use of an absorption chiller for air conditioning whlch cunverts the demland for chilled water into an equivalent demand for thermal energy, rather than electrical energy (which the present system uses). As indicated, the proposed system is sized to meet most of the thermal and electrical energy demands throughout the year. For those periods in which the demands are very high, and the insolation levels low, either the auxiliary heater or the existing equipment can be used to supply the extra energy required to meet the demands. 


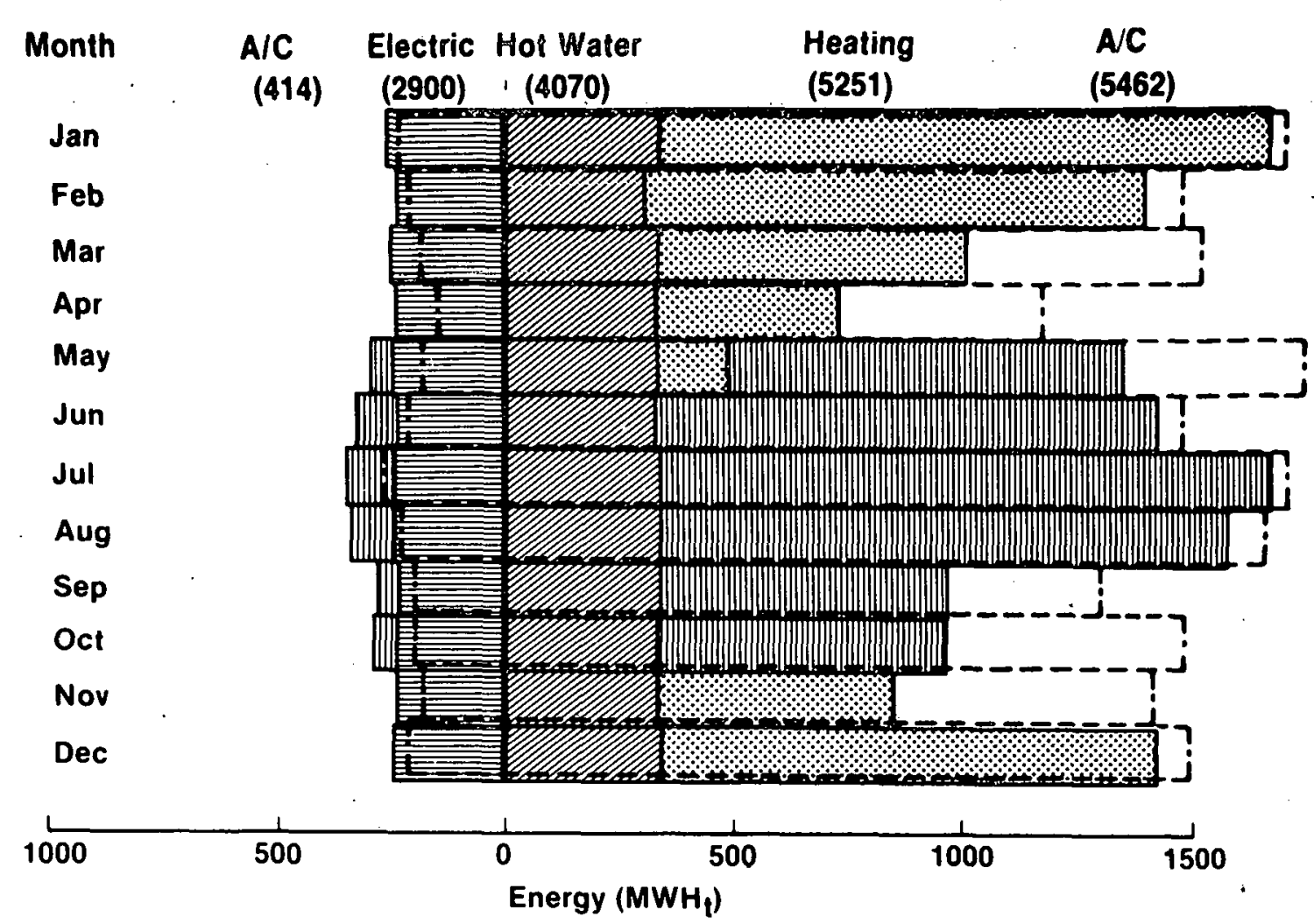

\section{Almual Cogeneration Capabilities}

( ) Annual Energy Demand in MWH $_{1}$

Figure 1.54. Monthly Energy Demands Absorption Chilling

Hourly variations in loads had a significant impact on the design of the plant and the storage capabilities required. The operational procedures of the facility will entail part-time turbine operation at rated power with energy being stored to meet thermal load demands the remainder of the 24-hour period. During the turbine operating period, chilled water will be generated by the absorption chiller for air conditioning during the summer days, and additional chilled water will be stored in tanks for nighttime demands. Likewise, during the winter months, heat will be stored in pressiurized water tanks for nighttime demands. Electrical power during the nighttime, while the turbine is idling, will be supplied from the existing electrical grid.

A summary. of annual energy usage and energy saved by the solar cogeneration facility at. Complex 87000 is shown on Table 1.5-1. As indicated, the solar system will result in a significant savings in both gas and electricity. The total savings are the equivalent of approximately 10,400 barrels of oil per year. These savings are compatible with the overall program objectives of reducing the use of critical fossil fuels. 
Table 1.5-1. Enorgy Sayert

\begin{tabular}{|c|c|c|c|c|c|c|c|c|c|}
\hline & \multicolumn{2}{|c|}{$\begin{array}{c}\text { CURRENT } \\
\text { ANNUAL USAGE }\end{array}$} & \multicolumn{2}{|c|}{$\begin{array}{c}\text { SCF } \\
\text { ANNUAL USAGE }\end{array}$} & \multicolumn{2}{|c|}{ ANNUAL SAVINGS } & \multicolumn{3}{|c|}{ EQUIVALENT ANNUAL OIL SAVINGS } \\
\hline & $\begin{array}{l}\text { POWER } \\
\left(M W_{E}\right) \\
(\end{array}$ & $\begin{array}{c}\text { GAS } \\
\left(M N_{T} H\right)\end{array}$ & $\begin{array}{l}\text { POWER } \\
\left(M_{E^{H}}\right)\end{array}$ & $\begin{array}{c}\text { GAS } \\
\left(M W_{T} H\right)\end{array}$ & $\begin{array}{r}\text { POWER } \\
\left(M W_{E}\right)\end{array}$ & $\begin{array}{c}\text { GAS } \\
\left(M N_{T}{ }^{M}\right) \\
\end{array}$ & $\begin{array}{c}\text { POWER } \\
\text { (BBL OIL) }\end{array}$ & $\begin{array}{c}\text { GAS } \\
\text { (BBL OIL) }\end{array}$ & $\begin{array}{c}\text { TOTAL } \\
\text { (BBL OIL) }\end{array}$ \\
\hline $\begin{array}{l}\text { ELECTRIC BASE } \\
(\mathrm{H} / 0 \mathrm{~A} / \mathrm{C})\end{array}$ & 2,900 & $\cdots$ & & --- & 2,629 & $\because-$ & 5,237 & $\therefore-$ & $\begin{array}{l}1 \\
1 \\
1\end{array}$ \\
\hline $\begin{array}{l}\text { AIR } \\
\text { CONDITIONING }\end{array}$ & 2,237 & -.- & $499)$ & & 1,738 & & 3,462 & ) & 1 \\
\hline $\begin{array}{l}\text { ROOM } \\
\text { HEATING }\end{array}$ & -- & 5,251 & -- & 6,926 & -- & 2,395 & -- & 1,753 & I) 5,215 \\
\hline $\begin{array}{l}\text { WATER } \\
\text { HEATING }\end{array}$ & --- & 4,070 & --- J & & --- & & --- & ( & 1 \\
\hline TOTAL & 5,137 & 9,321 & 770 & 6,926 & 4,367 & 2,395 & 8,699 & 1,753 . & 10,452 \\
\hline & $1 \mathrm{BBL}$ & $\mathrm{IL}=$ & ${ }^{K N} E_{E}^{A}$ & & & & & $\begin{array}{l}\text { 8 } \$ 115 / \mathrm{BBL} \\
\text { a } \$ 35 / \mathrm{BBL}\end{array}$ & $\begin{array}{l}=\$ 156,780 \\
=\$ 365,820\end{array}$ \\
\hline
\end{tabular}

\subsection{ECONOMIC FINDINGS}

Final costing and economic analyses have just been initiated at the time of this reporting and, consequently, there are no findings to be presented at this time. Summary results, which will be presented in the final report, will include the following:

- Economic assumptions

- Capital and O\&M cost suimmary

- Present value results

- Ecuriomic conclusions

\subsection{UEVELOPMENT PLAN}

Preliminary program milestones have been defined by DOE for cogeneration projects (Reference 11 ). These plans call for delailed design to begin in CY 1973, constructior to start in $\mathrm{Cr}$ 1984, and initial operations to begin in $\mathrm{CY} 1986$. A preliminary development schedule is shown on Figure 1.7-7, assuning a January start for each of these specified dates.

Tha task to prepare a site-specific development plan for the proposed Fort Hood Solar Cogeneration facility has not yet been initiated at the time of this 


\begin{tabular}{|c|c|c|c|c|c|c|c|}
\hline & FY80| & Y81 & EY82 & Y83 & v84 & Y85 & FY86 | \\
\hline & 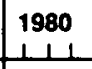 & $\begin{array}{l}1981 \\
1 ـ ـ ـ \\
\end{array}$ & $\begin{array}{r}1982 \\
\perp \perp \perp \perp \\
\end{array}$ & $\begin{array}{r}1983 \\
1 ـ ـ ـ ـ ـ ـ ـ ـ \\
\end{array}$ & $\begin{array}{r}1984 \\
1.1 \\
\end{array}$ & $\begin{array}{r}1985 \\
11+1 \\
\end{array}$ & $\begin{array}{r}1986 \\
ـ ـ ـ ـ ـ ـ ـ ـ ـ \\
\end{array}$ \\
\hline DOE Cogeneration Program P & & & & & & & \\
\hline - Conceptural Design & & & & & & & \\
\hline - Evaluation/Award Cycle & & & & & & . & \\
\hline - Prelliminary Design & . & & & & & & \\
\hline - Detailed Design & & . & & & 3 & Constr & \\
\hline - Construction and Checkout & & & & & & & 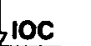 \\
\hline - Operation & & & & & & & \\
\hline
\end{tabular}

Figure 1.7-1. Solar Cogeneration Facility Program Plans

reporting. Summary results, which will be presented in the final report, will include the following:

- Development phases (detailed design, construction, operation)

- Development schedule

- Development plan conclusions

\subsection{SITE OWNER'S ASSESSMENT}

An assessment of the proposed solar cogeneration facility by the U. S. Army will be made and reported at the conclusion of the study effort. Assessment topics will include:

- Endorsement of project results

- Assessment of project worth

- Operation, safety and environmental impact/benefits

- Project development plan and schedule

- Energy problems and planning strategies

- Alternatives to solar cogeneration systems

- Institutional and regulatory considerations

- Acceptability assessment 


\section{THIS PAGE WAS INTENTIONALLY \\ LEFT BLANK}


Section 2

INTRODUCTION

The Fort Hood Solar Cogeneration Facility Concept Design Study has been conducted for the Department of Energy under contract number DE-AC03-81SF11495. The McDonnell Douglas Astronautics Company (MDAC), with the support of the Stearns Roger Company and the University of Houston Energy Laboratory, conducted the nine month study from December 1, 1980 through August 31,1981 . Total contract price was $\$ 387,097$. Further information may be obtained from the MDAC Program Manager:

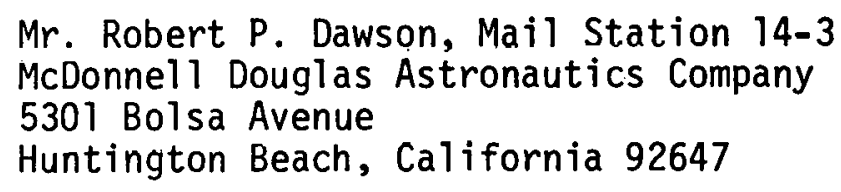

\subsection{STUDY OBJECTIVE}

The specific objective of this project was to initiate the development of a solar cogeneration facility at the Fort Hood Army Base, Killeen, Texas, by. conducting a site-specific conceptual design study and by defining subsequent development plans.

This project is part of the U.S. Department of Energy's total energy program to deilunstrate the technical, economic, and institutional feasibility of a central receiver solar cogeneration facility in which solar energy is collected and used to provide both high-grade energy for the generation of electricity and low grade energy for space heating and cooling, water heating and other useful purposes.

Project yoals stipulated by DOE were:

- to make effective use of solar thermal energy from a solar central receiver system integrated into a cogenerating facility, 
- to have the potential for construction and high reliability operation by 1986 ,

- to provide the best possible economics for the overall plant or facility application,

- to have the potential to achieve wide commercial success, and

- to offer the potential for significant saving in critical oil and gas fuels.

Study results were to provide the DOE and industry with:

- conceptual definition of a solar cogeneration facility design,

- preliminary estimates of system performance and costs,

- preliminary estimates of technical, economic, institutional, regulatory, and environmental benefits of, and barriers to the solar cogeneration facility project,

- preliminary estimates of development test requirements, costs, and schedules for subsequent demonstration projects, and

- an indication of potential user cost sharing arrangements with the Department of Energy for subsequent demonstration projects.

There were no requirements for hardware development or testing during this phase.

\subsection{TECHNICAL APYROACII AND SITE SELECTION}

\subsubsection{Approach}

In order to accomplish the objectives of this contract, the technical effort was divided into seven major tasks, which were:

1. Preparation of System Specification

2. Selection of Site-Specific Configuration 
3. Facility Conceptual Design

4. Facility Performance Estimates

5. Facility Cost Estimates and Economic Analyses

6. Development Plan

7. Program Management

An overall study task flow with major inputs and outputs is shown on Figure 2.2-1, and the specific task schedules are shown on Figure 2.2-2. The nine month study began with the performance of Tasks 1,2 and 7 . Task 2

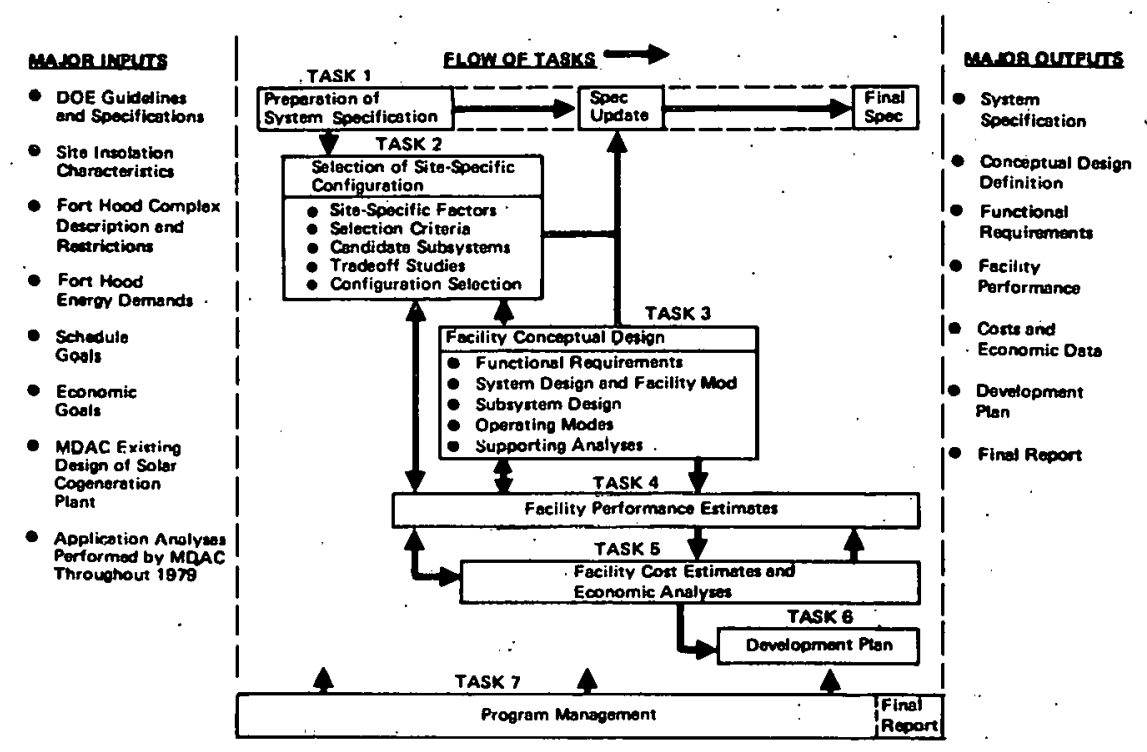

Figure 2.2-1. Study Task Flow

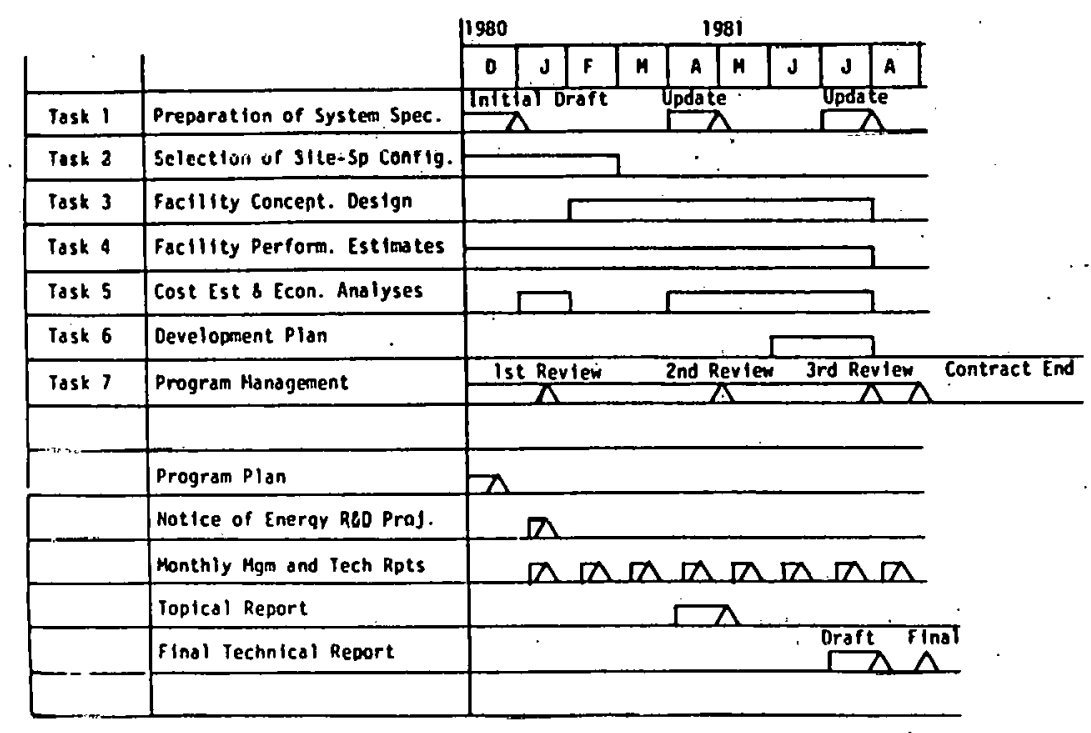

Figure 2.2-2. Study Schedule 
(Selection of Site-Speclfic Cunfiguration) was concluded after approximately four months with the selection of a preferred configuration. Task 3 (Facility Conceptual Design) further defined this baseline configuration. Task 4 (Facility Performance Estimates) and Task 5 (Facility Cost Estimates and Economic Analyses) were conducted in parallel with Tasks 2 and 3 to provide necessary support. Task 6 (Development Plan) was initiated later in the study period when the baseline configuration was better defined. Task 1 . (Preparation of System Specification) and Task 7 (Program Management) were conducted throughout the study period, as required. A more detailed explanation and approach for each of these tasks was published earlier in the Program Plan (MDC G9329, December 1980).

To meet the goals stipulated by DOE, specific design criteria were developed for this project that were used throughout the study effort. These basic criteria are summarized on Figure 2.2-3. The proposed solar cogeneration facility meets these criteria.
- apPLY MDAC GENERIC SYSTEM DESIGN TO SITE-SPEĊIFIC APPLICATION
- Utillize solar equipMEnt pREVIOUSLy gualified by doE

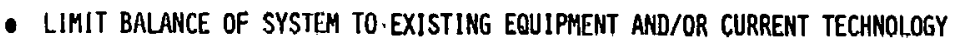
- Minimize Impact on base facilitites and oṕë́rations
- MAXIMIZE USE OF REJECTED THERMAL ENERGY (MINIMIZE ENERGY LOSSES)
- DESIGN TO MEET COMPLEX. 87000 REQUIREMCNTS AS MUCH AS POSSIBLF
- INCORPORATE DESIGN FLEXIBILITY FOR OTHER MILITAPY BASE APYLIICATIONS

Figure 2.2-3. Fort Hood Design Approạch

\subsubsection{Site Selection}

The Fort Hood Army Base at Killeen, Texas was selected for a solar cogeneration facility for the following reasons: (1) it is one of the largest military bases in the U.S. and has a very high annual consumption of electricity and fuel (natural gas), (2) several studies for solar installations at Fort Hood have been conducted in couperation with the Army since 1974 and considerable technical information was available (References 3-8), (3) Fort Hood is in a region of reasonably good insolation ( $\cong 5 \mathrm{KWh} / \mathrm{m}^{2} /$ day), and is an excellent application for the proposed solar cogeneration facility which must supply both electrical energy and thermal energy for domestic 
hot water and space conditioning, (4) the Army is committed to the reduction of critical fossil fuels and to the development of solar energy systems at Fort Hood, and has encouraged the installation of such a solar central receiver system at their base (References 1 and 2), and (5) a small solar central receiver system at Fort Hood was suggested by DOE in the request for proposal (Reference 10, Enclosure VIII, Attachment 1) and by DOE/JPL when the contract of the MDAC team on Phase I of the first small power system experiment was ended (Reference 9). Accordingly, MDAC conducted a significant company-sponsored study of this application prior to this study contract, and initial results were very encouraging.

Within Fort Hood, Complex 87000 was selected for the solar cogeneration installation because it is representative of the concentrated usage of thermal energy for space conditioning and hot water, it offered the greatest flexibility for collector field location, and considerable technical information was available from previous solar studies at this complex.

\subsection{SITE LOCATION}

The Fort Hood Army Base is located immediately west of Killeen, Texas, approximately mid-way between Fort Worth and San Antonio, as illustrated on Figure 2.3-1. Fort Hood is the free world's largest armor post, and is

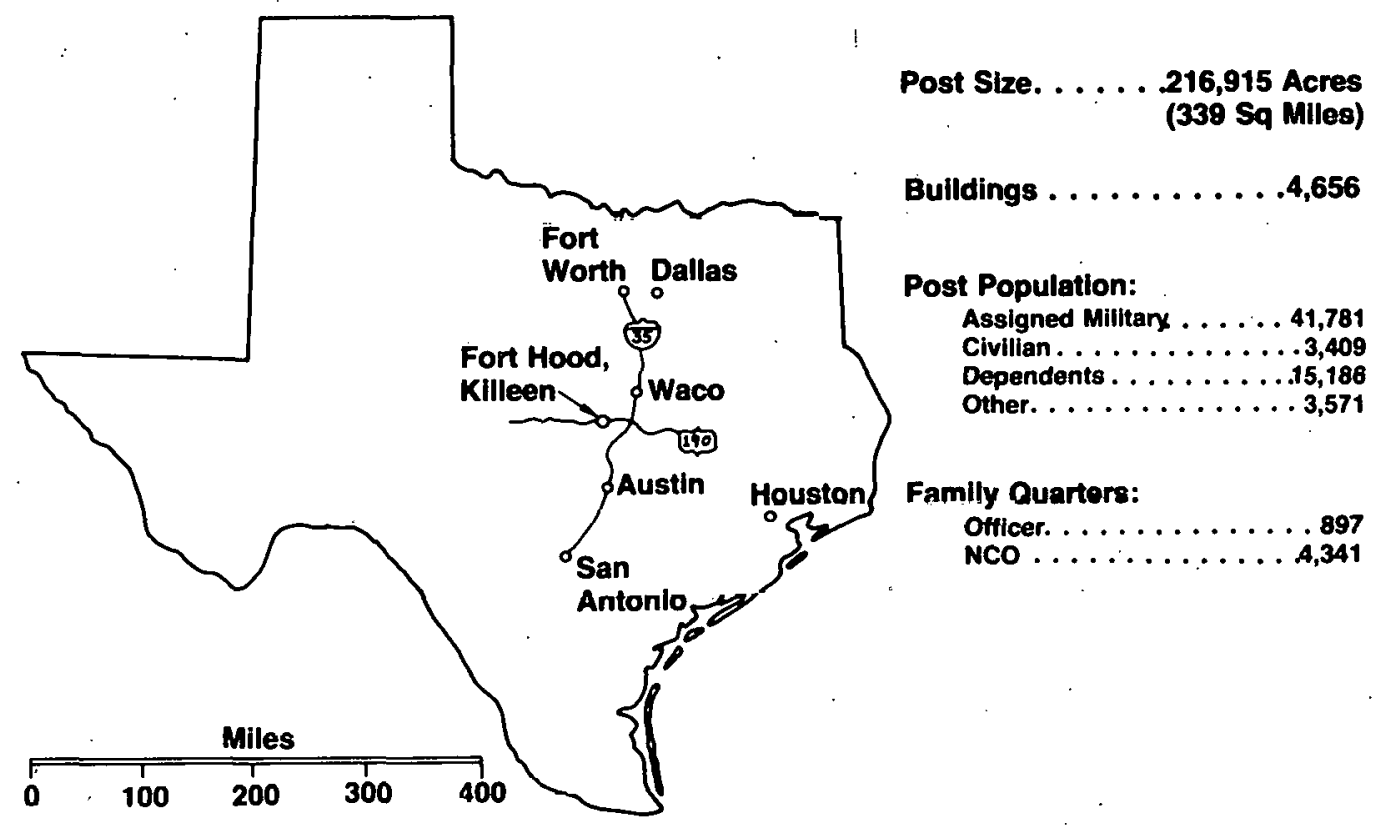

Figure 2.3-1. Fort Hưud General Information (As of 30 Nov 1980) 
presently the home for the III Corps, the 1st Cavalry Division, the 2nd Armored Division, the 6th Cavalry Brigade, 13th Corps Support Command, and MEDDAC (Darnall Army Hospital). The base includes the Fort Hood Army Air Field and the Robert Gray Army Air Base. The size of the post, population and other basic statistics are given on Figure 2.3-1. The Fort Hood Military Reservation occupies 339 square miles, and is composed of three areas: the Main Post, West Fort Hood, and North Fort Hood, as shown on Figure 2.3-2. The Main Post, which occupies approximately eight square miles, is adjacent to the town of Killeen, which is shown as the darker area on Figure 2.3-3.

Complex 87000 is located at the eastern edge of the Main Post, as circled on Figure 2.3-3. This complex consists of a group of 20 buildings of contemporary Army design that provides the housing, food services, administration, dispensary, $P X$, storage, recreational, central energy anci other services for a brigade-size complement of troops (approximately 1,650). As illustrated on Figure 2.3-4. The solar equipment will be located in the open field to the east of the 87000 troop housing complex, and will directly interface with the existing central power plant that presently provides all power and space conditioning for the complex. The proposed site for the installation of the solar equipment is bounded by existing roads (15th Street, Battalion Avenue, Martin Drive, and the planned extension of Central Avenue). A small parking lot and park within this area would be relocated.

\subsection{SITE GEOGRAPHY}

\subsubsection{Site Topography}

Fort Hood is located at a latitude of $31^{\circ} 07^{\prime} \mathrm{N}$ and a longitude of $97^{\circ} 43^{\prime} \mathrm{W}$. Elevation is 796 feet above mean sed level. The terrain is generally flat with small hills. The terrain at the Main Post exhibits a small downward ijlupe, east and snuth at a rate of approximately 10 feet per mile and an upward slope, north and west of the post at a rate of one foot per mile. The proposed site for the solar equipment at Complex 87000 is essentially flat.

The soils at Complex 87000 are of the Denton Association soil series with a surface layer of dark brown silty clay from 5 to 54 inches thick above 


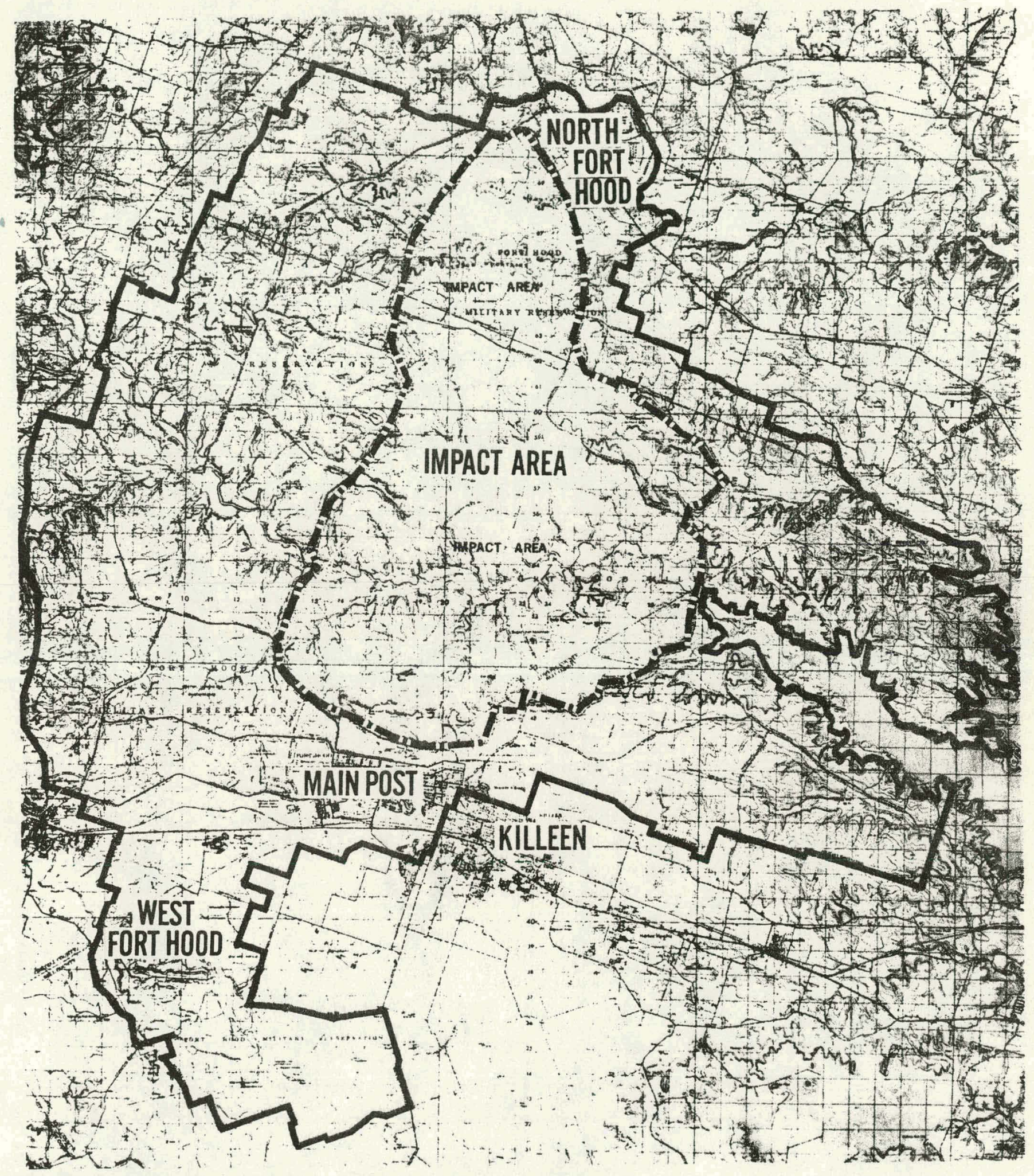

Figure 2.3-2. Map of Fort Hood Military Reservation 


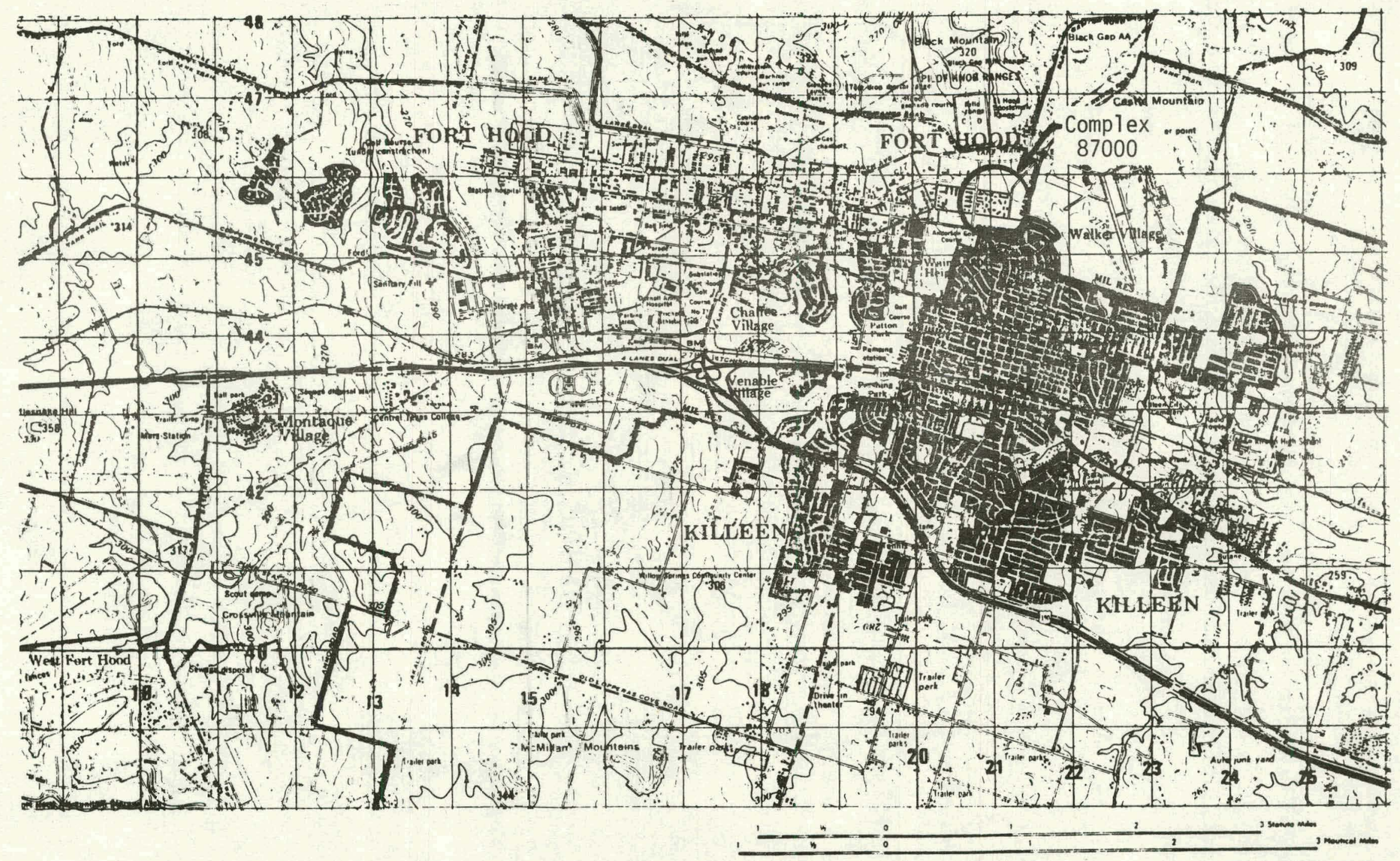

Figure 2.3-3. Fort Hood Army Base Killeen, Texas 


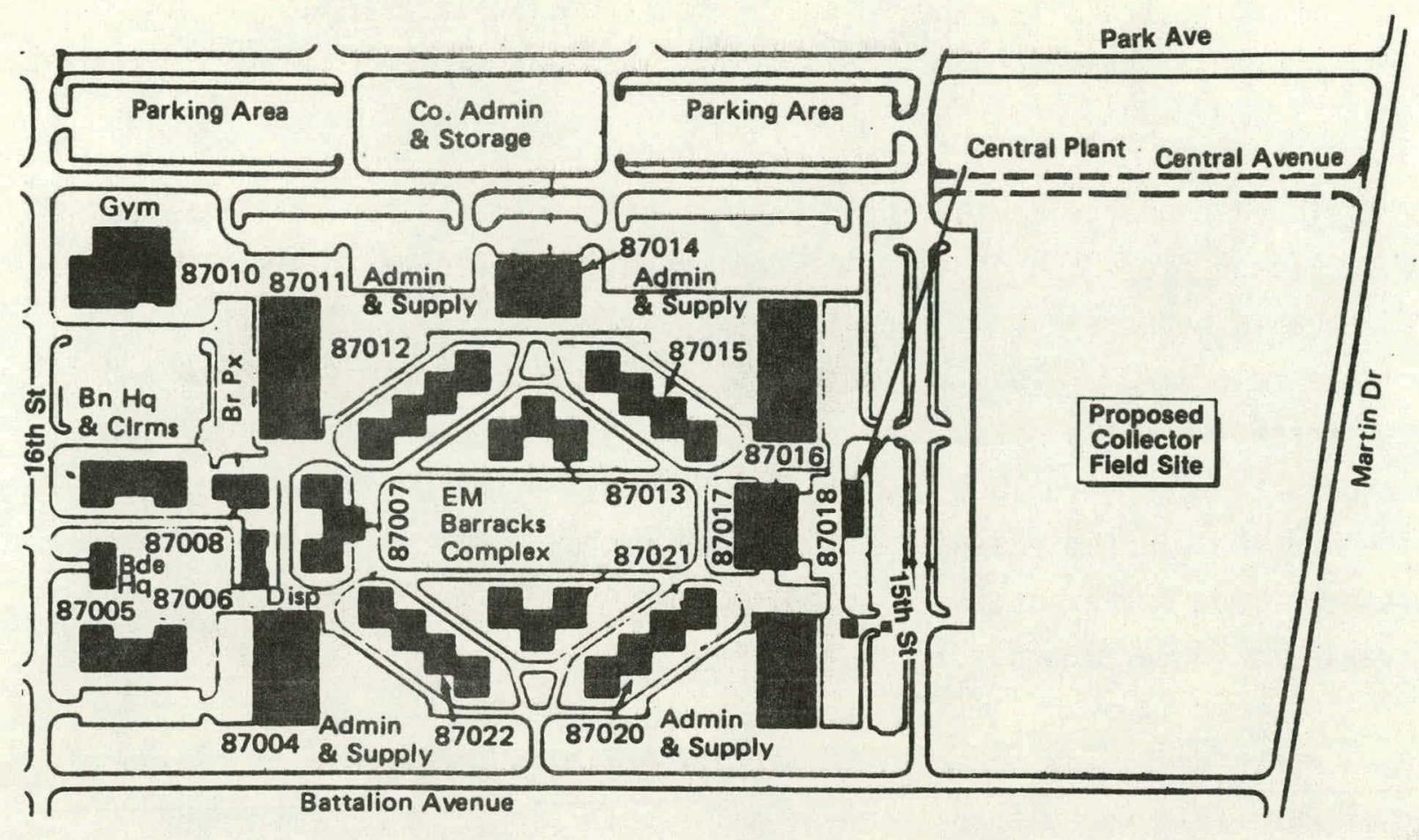

$$
\begin{aligned}
& \text { Buildings _ _ } \ldots \ldots-\ldots-\ldots-20(438,252 \mathrm{Sq} \text { Ft Floor Area) } \\
& \text { Barracks _ _ - }-\ldots \ldots \ldots-7 \text { (264,150 Sq Ft) } \\
& \text { Occupancy _ } \ldots \ldots \ldots \ldots-\ldots 1650 \text { (Design) }
\end{aligned}
$$

Figure 2.3-4. Fort Hood Complex 87000

fractured limestone as the underlying material. The proposed site lies in the drainage basin of the north and south branches of Nolan Creek. This creek flows into the Little River and Brazos River which empties into the Gulf of Mexico south of Houston.

Fort Hood is located in U.S. Seismic Zone zero (0) which is an area expected to have no seismic risk. No known earthquakes have occurred at the site.

\subsubsection{Solar Plant Location}

As reviewed in Section 2.6, thermal energy demands of Complex 87000 are supplied through the Central Energy Plant (Building 87018), which is located at the eastern edge of the complex, as shown on Figure 2.3-4. Steam and chilled water lines originate at this building and travel underground to the other buildings within the complex. In order to minimize the modifications 
to the existing facility, the solar cogeneration facility should be located near the Central Energy Plant and all interfaces should be made at this point.

The field east of the Central Energy Plant has been selected as the site for the collector field and other plant equipment, as reviewed in Section 2.3. This area is underdeveloped except for a parking lot and small park that would be relocated. Also, a single elevated power line running north and south through the field would be rerouted. The collector fiald area is not to exceed the land area bounded by 15th Street, Battalion Avenue, Martin Drive and the planned extension of Central Avenue. Appropriate allowances have been made for setbacks, fenciny, and an inside pcrimeter service road, as reviewed in Section 3.4.1.

With a north field collector field layout, there is ample room at the south end of the field for the location of major solar equipment items and necessary structures. The tower has been located as close as possible to. the southern boundary in order to permit the optimum number and arrangement of heliostats. At the present time, there are no known restrictions on tower height. There is an air field that is used primarily for helicopter operations to the east of Complex 87000 . The solar tower is located approximately 4,000 feet to the side of the runway centerline and is not expected to be a hazard to aircraft operations. The tower will be equipped with appropriate aircraft warning lights. Communication interferences are also not expected to be a problem.

\subsection{CLIMATE}

\subsubsection{Solar Insolation}

To support the development of the site-specific configuration and optimum collector field size, tower height, and subsystem component sizes, a detailed direct normal insolation model had to be developed which would account for local weather conditions. Detailed insolation data for Waco, Texas, which is approximately 46 airline miles northeast of Killeen, were obtained from the National Climatic Center. The reference document, "Input Data for Solar Systems," was prepared for the U. S. Department of Energy by V. Cinquemani, J. R. Owenby, Jr., and R. G. Baldwin under Interagency Agreement No. E 
(40-26)-1041, reprinted in March 1980. This document provided total hemispheric mean daily solar radiation data at Waco based on SOLMET rehabilitated data for a 24 - 25 year period. Comparison of these data for Waco with the American Technological University (ATU) Fort Hood model (Reference) and the Sandia Fort Worth Model (Reference) showed good agreement with slight conservatism, as illustrated on Figure 2.5.1-1. Due to the lack of insolation data for Killeen, it was decided that the Waco total horizontal insolation data were representative of the site and should be used for modeling the direct normal insolation for the conceptual design.

Many models have been proposed for calculating direct normal radiation from horizontal insolation data. These models include the watt model, the Aerospace model, the Liu and Jordan model, the Meinel model, the Hottel model, the University of Houston model, and others. Some of these models vary substantially, as shown in Figure 2.5.1-2, in which the Aerospace and Watt models are compared. However, for the Fort Hood site, both models are in good agreement and indicate that an annual daily average direct normal insolation is approximately $5.0 \mathrm{kWh} / \mathrm{m}^{2}$.

Under subcontract, the University of Houston generated a direct normal insolation model for Waco, Texas. This model is very similar to the Watt model and has high accuracy due to a minimum of assumptions. It starts with the extraterrestrial insolation and then considers the earth eccentricity, site latitude

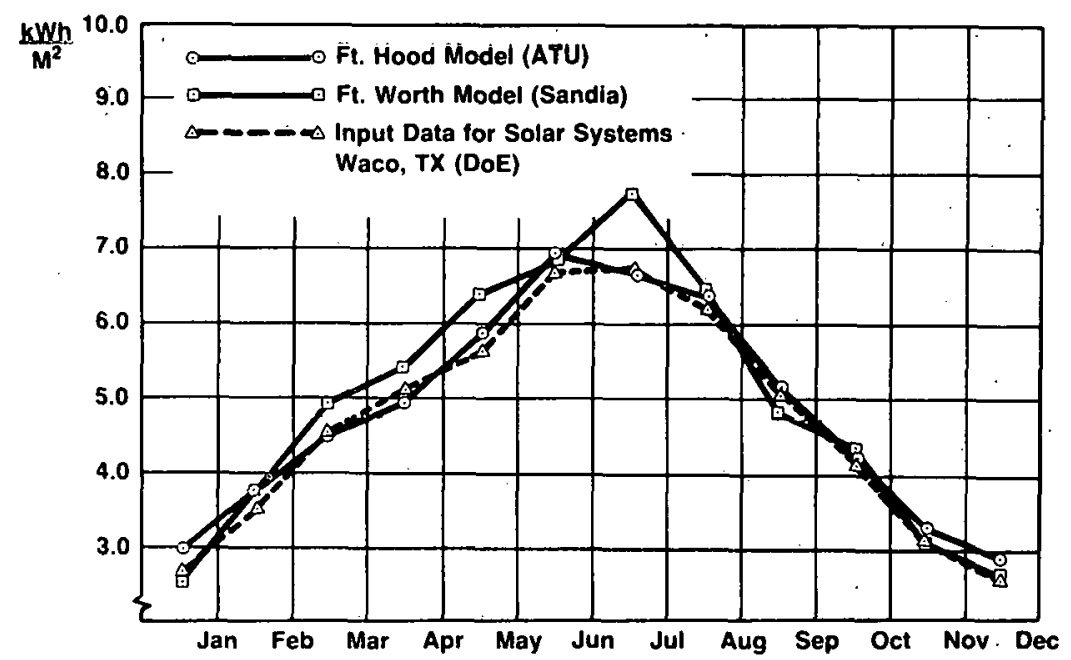

Figure 2.5.1-1. Total Hemispheric Mean Daily Solar Radiation 


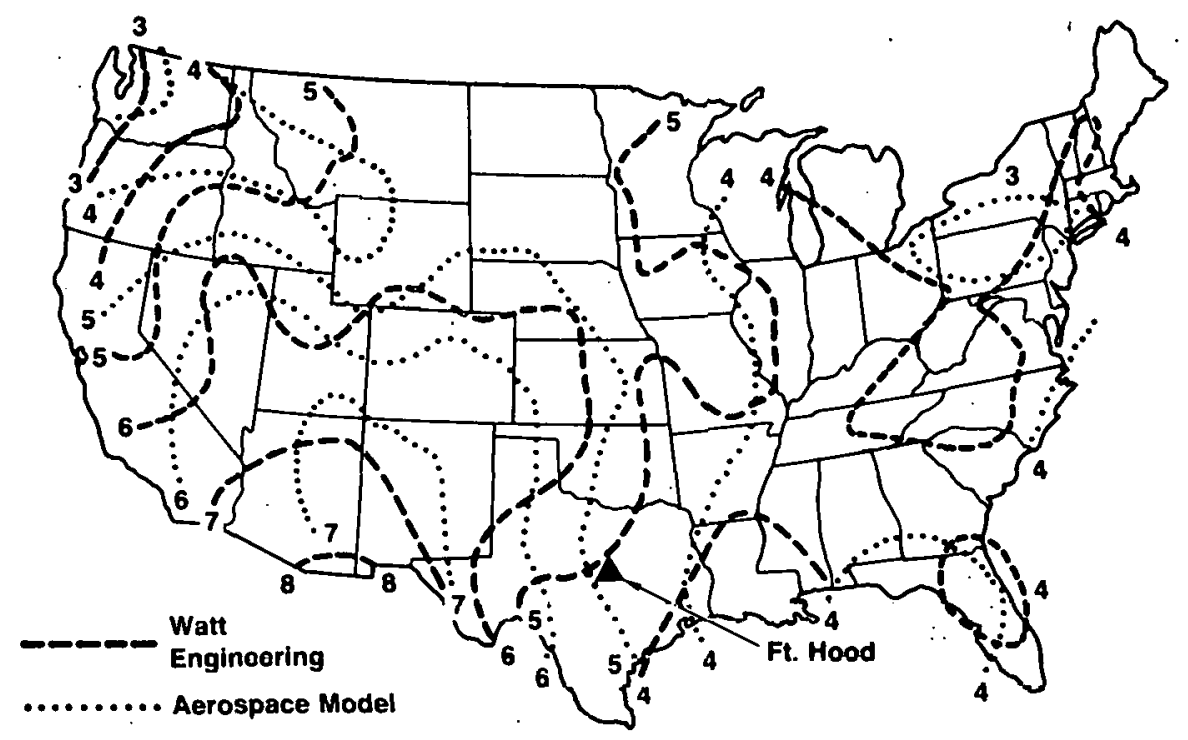

Figure 2.5.1-2. Annual Daily Average Direct Normal Isolation (kWh/M $\mathrm{M}^{2}$ Day)

and elevation, atmospheric turbidity, cloud cover, and precipitable water. The University of Houston's model predicts an annual direct normal insolation of $4.93 \mathrm{kWh} / \mathrm{m}^{2}$ per day, which is in excellent agreement with the watt and Aerospace models.

In parallel, MDAC evaluated a modified Liu and Jordan model. This model uses the previously verified total horizontal insolation as input, correlates. these data to the SOLMET weather data, and generates the predicted direct normal insolation. The Liu and Jordan model predicts an annual daily average direct normal insolation of $4.90 \mathrm{kWh} / \mathrm{m}^{2}$. This excellent agreement with the University of Houston model provides verification of the models, using independent sources and inputs. Figure 2.5.1-3 shows the agreement of the twn models and the seasonal variation in insolation at Waco. To develop the insolation for Fort Hood, the University of Houston's direct normal insolation data was used for the conceptual design. Houston then modified the Waco model for the site-specific latitude and elevation (Figure 2.5.1-4).

The University of Houston modeled the diurnal variations in insolation for one day in each month. The solstice and equinox days are shown in Figure 2.5.1-5. These diurnal curves have been checked and verified against the SOLMET Aerospace model for a Typical Meteorological Year (TMY). The TMY data show that a peak insolation level of up to $1000 \mathrm{w} / \mathrm{m}^{2}$ at the site can occur; however, 


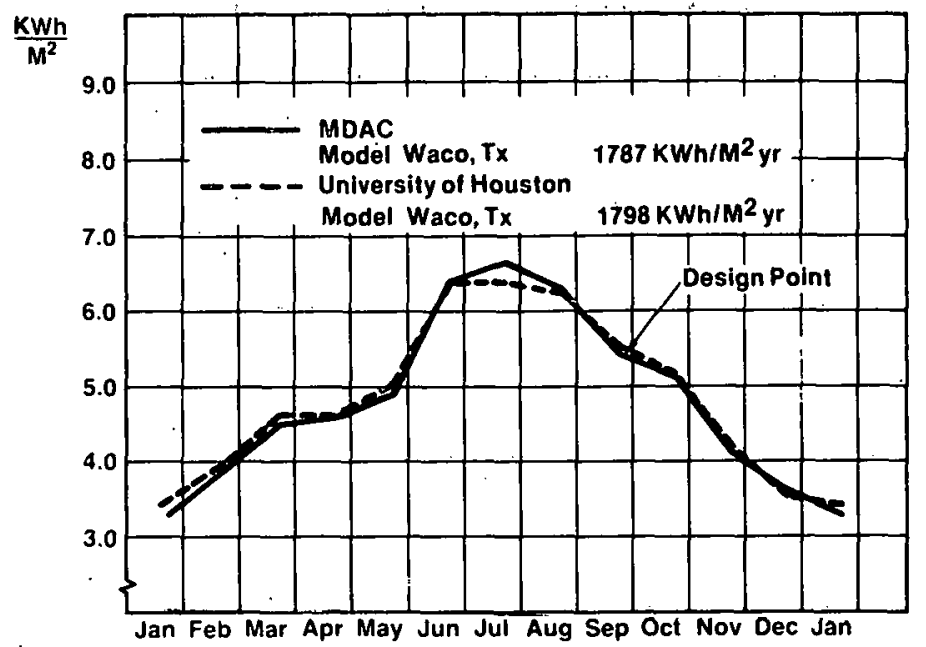

Figure 2.5.1-3. Average Daily Direct Normal Insolation

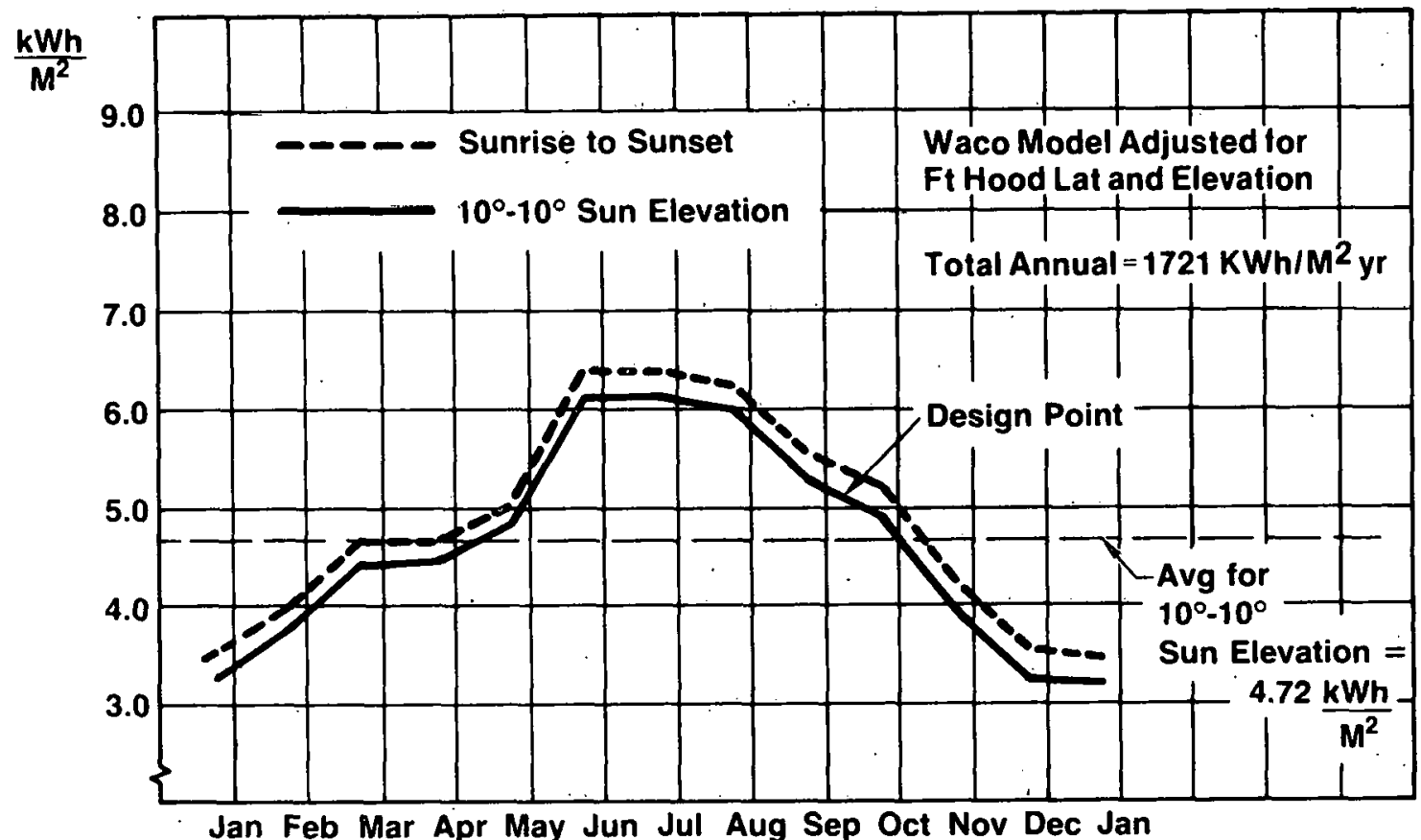

Figure 2.5.14. Fort Hood Direct Normal Insolation University of Houston Model

this occurs very infrequently. More typically, the summer solstice peak is $930 \mathrm{w} / \mathrm{m}^{2}$, winter solstice is $920 \mathrm{w} / \mathrm{m}^{2}$, and the equinox peak is $940 \mathrm{w} / \mathrm{m}^{2}$. These values are for clear days. Due to the occurrence of more clear days during the fall equinox, and the close agreement between TMY data and University of Houston's diurnal model for equinox, and also because the equinox sun position is somewhat of an average between the solstices, a fall equinox (September 21) day was chosen for design purposes. Thus, the design point insolation is $940 \mathrm{w} / \mathrm{m}^{2}$. 


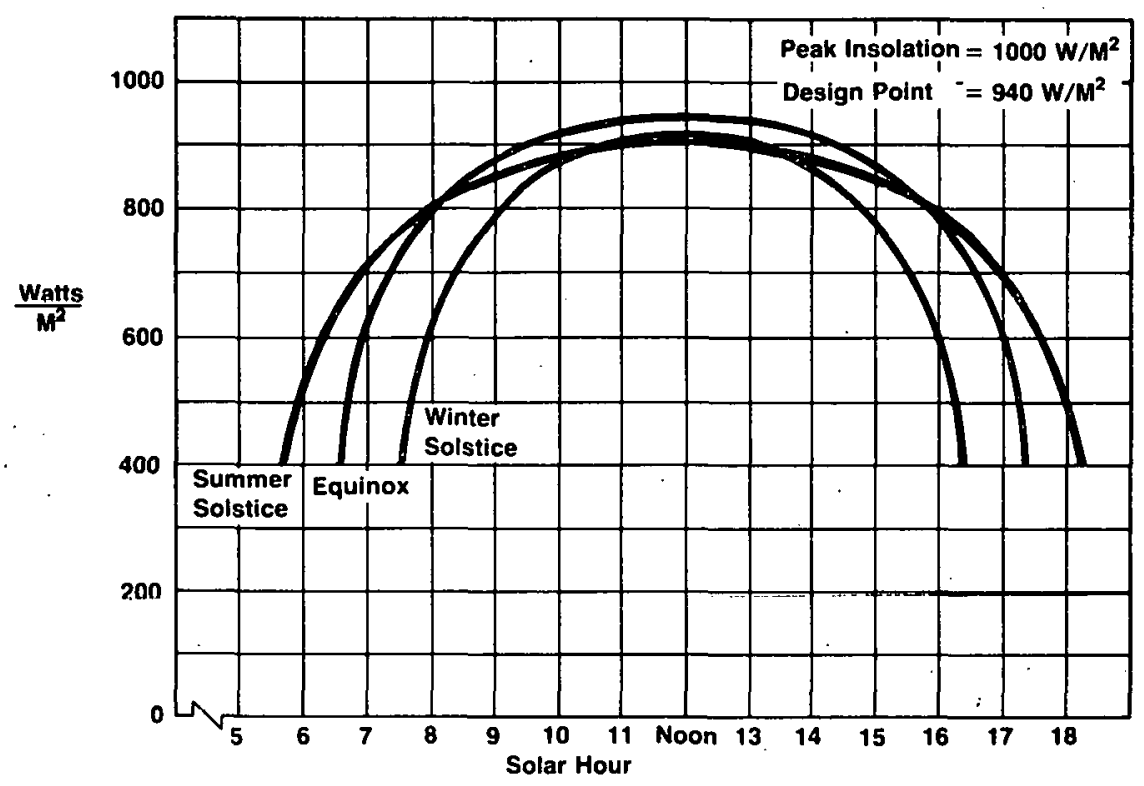

Figure 2.5.1-5. Clear Day Normal Insolation

\subsubsection{Meteorological Data}

Killeen is located in the western part of Bell County, in central Texas. The surrounding terrain is level to hilly, cut by the Lamposas and Leon Rivers and their tributaries.

The climate of Killeen is humid and subtropical with hot summers, although the city is located very near the western boundary of this particular climatic region. Precipitation decreases somewhat in winter, which is a climatic characteristic of the region to the west of Killeen. Tropical Maritime air controls the climate of the region during the spring, summer, and fall. During the winter months, Polar Canadian air masses predominate, although these cold air masses are modified considerably by the time they reach Central Texas. The prevailing winds at killeen are southerly throughout the year, with an average speed of $4.9 \mathrm{~m} / \mathrm{s}(11 \mathrm{mph})$. The strongest winds that are observed at Killeen are the gusts and squalls associated with thunderstorms. The strongest persistent wind speeds occur in March and April in association with intense low pressure centers (extratropical cyclones) that move eastward from the Texas Panhandle. Rainfall is most frequent, and heaviest, during April, May, and June. A secondary rainfall peak occurs in the fall months of September and 0ctober. In an average year, January and March are relatively dry months, as are July and August. The mean total annual rainfall for the 17 -year period 
1951-1967, is $77.6 \mathrm{~cm}$ (30.55 inches). This period is too short to establish a reliable estimate of the mean, and estimates of the 1931-1960 precipitation "normal" for Killeen, based on surrounding stations with 30 years of record, is $81.3 \mathrm{~cm}$ (32 inches). Since moisture laden Tropical Maritime air is so often present, torrestial downpours of short duration may occur almost any time during the year. As much as $10.2 \mathrm{~cm}$ (4.0 inches) of precipitation have fallen within a single 24-hour period in February, which is not usually a wet month. The variability in annual total precipitation is illustrated by the amounts which fell during the wettest and driest years, and which occurred only three years apart. A total of $138.5 \mathrm{~cm}$ (54.53 inches) fell in 1957, the wettest year, while only about one-fifth of this amount, $28.7 \mathrm{~cm}$ (11.30 inches), fell in 1954, the driest year. At Killeen there exists a wide range between annual temperature extremes also, typical of continental climates. The mean monthly temperature is $18.9^{\circ} \mathrm{C}\left(66^{\circ} \mathrm{F}\right)$ with a record high of $44.4^{\circ} \mathrm{C}\left(112^{\circ} \mathrm{F}\right)$ and a low of $-20.6^{\circ} \mathrm{C}\left(-5^{\circ} \mathrm{F}\right)$.

The relative humidity is fairly uniform throughout the year; however, it does. vary considerably during the day. The average annual relative humidity is approximately 82 percent at 6:00 a.m., 54 percent at noon, and 50 percent at 6:00 pm.., Central Standard Time. The mean annual sunshine received is about 62 percent of the total possible, but varies from about 55 percent in winter to 75 percent in summer.

Winter: Generally, temperatures are mild, and cold spells are quite brief. The minimum temperature crops to $0^{\circ} \mathrm{C}\left(32^{\circ} \mathrm{F}\right)$ or below on less than one-half of the winter nights. There is often considerable cloudiness in the morning which breaks up about noon and is followed by sunshine and warmer temperatures during the afternoon. Snow is usually of little or no consequence, often melting as rapidly as it falls with no accumulation on the ground. Measurable amounts are rare.

Summer: Daytime temperatures are hot in Killeen, and refrigerated type airconditioning is recommended for maximum comfort indoors.

Spring and fall are delightful seasons with moderate temperatures, characterized by mild days and cool nights. Visibility is generally good, with $70 \%$ of the days per year having visibility greater than seven miles. 
The mean length of the warm season (freeze-free period) is approximately 260 days. The mean dates of the last occurrence of $0^{\circ} \mathrm{C}\left(32^{\circ} \mathrm{F}\right)$ or below in the spring, and the first occurrence in the fall, are March 9 and November 24, respectively.

The National Climatic Center (NCC) was contacted, and climatography reports were obtained for Waco, TX (37 years of data) and Killeen, TX (11 years of data). Data evaluation showed the two cities to have very similar weather characteristics. Due to the availability of considerably more weather data for Waco, and their similar insolation characteristics, it was decided that Waco weather data was representative of the site, and would be used for conceptual design purposes.

\subsection{EXISTING PLANT DESCRIPTION}

\subsubsection{Central Energy Plant}

The demand for steam and chilled water to provide space conditioning and domestic hot water for the buildings in the complex is supplied from a central energy plant, shown in Figure 2.6.1-1. The plant has two natural gas fired fire-tube boilers supplying $15 \mathrm{psig}$ steam and two centrifugal refrigeration machines supplying $42^{\circ} \mathrm{F}$ chilled water. Auxiliary equipment includes a condensate pumping unit with head tank and two pumps, a chilled water circulating system with two pumps and an air separation tank, and a heat rejection system with two pumps and an evaporative cooling tower.

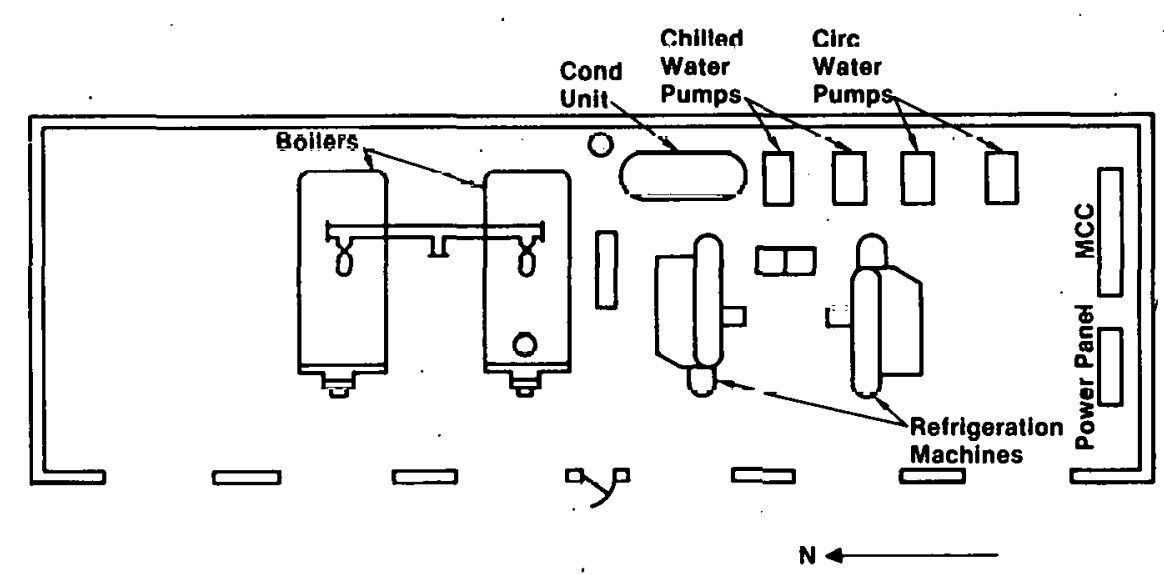

Figure 2.6.1-1. Complex 87000 Central Energy Plant 
Electrical power for operating the equipment and lighting is supplied through a main switchboard to a motor control center, two motor starter cabinets for the refrigeration machines and two lighting panels. The power is supplied from two articulated 750 KVA transformers located next to the building. The secondary voltage from these transformers to the plant is $480 / 277$ volt. The primary side of the transformers is connected to the base power distribution network and is at 12,470 volts. The feed to these transformers is from underground power cables.

Natural gas is supplied from an underground three-inch pipe. The pressure to the boilers is regulated at TBD psig by a pressure regulator located on the outside of the building. The maximum usage rate of gas is approximately 30,000 cubic feet per hour. The pressure in the base distribution system is 10 psig.

The control system for the boilers and centrifugal refrigeration machines requires an operator to check out the systems and place them in service initially. The systems will then automatically modulate to maintain 15 psig steam pressure and $42^{\circ} \mathrm{F}$ chilled water to the complex. The control systems have sensors and relays that will shut down the boiler if the water level drops too low and shut down the refrigeration machines if the chilled water temperature drops too low or if the chilled water flow stops.

\subsubsection{Electrical Power Distribution System}

The electrical power for the complex is taken from the base power network at several points around the complex. Four transformers are located adjacent to the central energy plant and supply power to the energy plant, nearby buildings, and area lighting. There are six other transformers located throughout the complex which supply power to nearby buildings, and area lighting. The power distribution network for the base and the complex is 12,470 volt, three phase/ac. The transformers supplying the central energy plant and the food service step the primary voltage down to 480/277 volt, and the remainder of the transformers step the primary voltage down to $208 / 120$ volt. Protective relaying, controls, and metering have yet to be determined. 


\subsubsection{Air. Conditioning System}

Air conditioning requirements for the complex are satisfied by a chilled water system shown in Figure 2.6.3-1. Chilled water at $6^{\circ} \mathrm{C}\left(42^{\circ} \mathrm{F}\right)$ is produced by two centrifugal refrigeration machines connected in series and located in the central energy plant. The chilled water produced is distributed to the complex by an underground pipe network. In each building a circulating pump takes suction from the chilled water line and supplies the chilled water to thermostatically controlled fan/coil units which remove the heat from the air. The water from the fan/coil units flows into the chilled water return piping network and is returned to the central energy plant at approximately $14^{\circ} \mathrm{C}\left(58^{\circ} \mathrm{F}\right)$. The heat removed from the return water by the refrigeration machines is rejected to the atmosphere by an evaporative, mechanical draft cooling tower.

Electric power for the centrifugal refrigeration machines 15 supplied through a separate motor starter/circuit breaker. for each machine. The power for the circulating water pumps, the chilled water pumps, and the cooling tower fan is supplied through the main motor control center by individual circuit breakers. The power to the motor starters and motor control center is through the main step-down transformer for the central energy plant from the base power grid via underground power cables.

Chilled water is produced by two contrifugal refrigeration machines which are connected in series. The total capacity of the two machines is 948 tons of refrigeration at a chilled water temperature of $6^{\circ} \mathrm{C}\left(42^{\circ} \mathrm{F}\right)$ and a circulating water inlet temperature of $29^{\circ} \mathrm{C}\left(85^{\circ} \mathrm{F}\right)$. The electric power usage at maximum load is 790 kilowatts total with both machines operating.

The chilled water is distributed to the complex from the central energy plant via a network of underground pipe. The connections at the central energy plant are eight-inch nominal pipes for both the chilled water line and the chilled water return line. Circulation is by two motor driven, horizontal shaft, split case centrifugal pumps rated at $711 \mathrm{gpm}$ at 170 feet of developed head each. Within each mechanical room, a circulating pump supplies chilled water at a maximum rate of $335 \mathrm{gpm}$ to several fan coil units in the building (200-800 CFM). The pump is started manually and flow is regulated by a control valve positioned by a controller which senses return line temperature. 


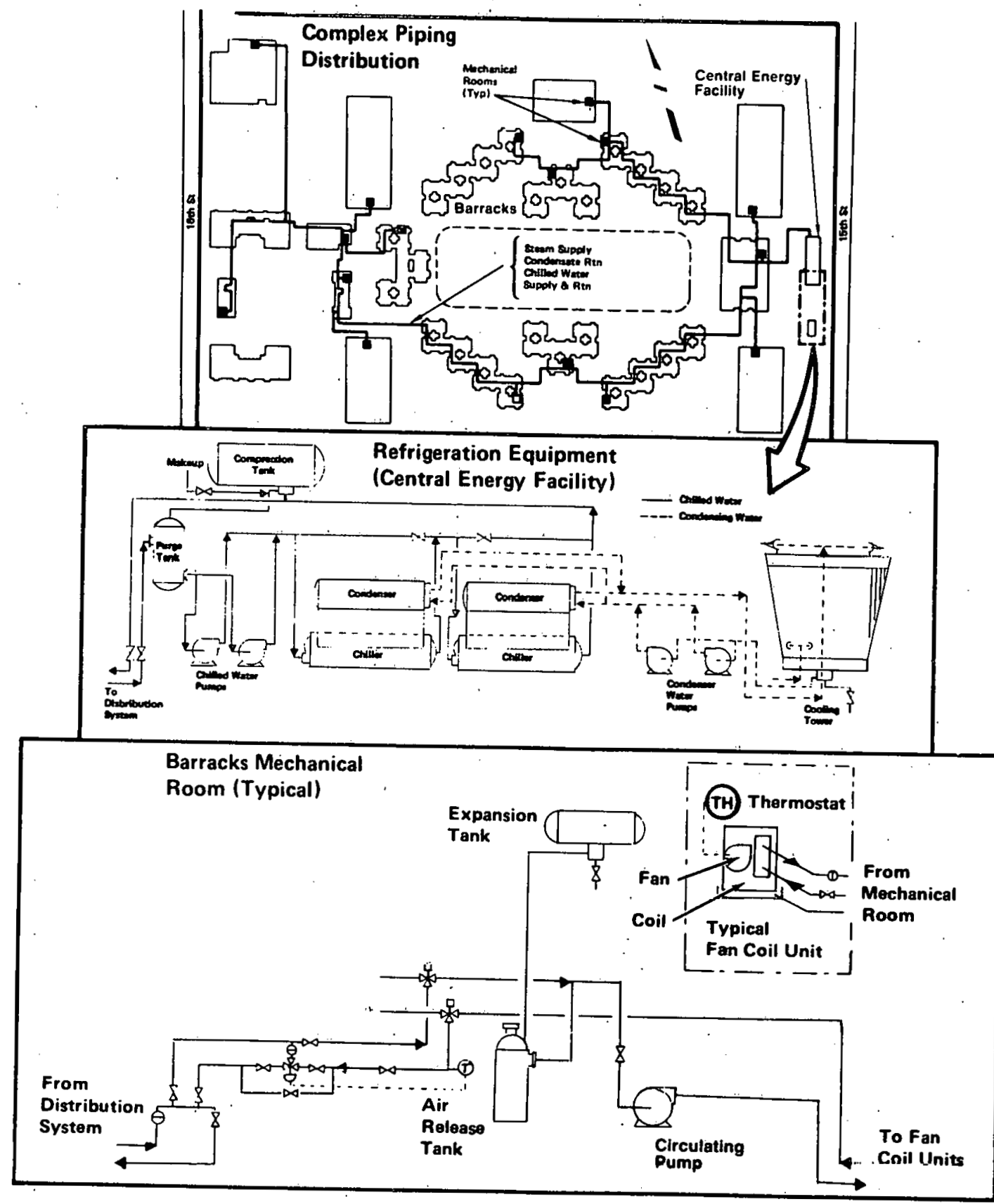

Figure 2.6.3-1. Existing Chilled Water Equipment for Air Conditioning 
Heat from the refrigeration machines is rejected to the atmosphere by an evaporative, mechanical induced draft cooling tower. The tower will cool $2844 \mathrm{gpm}$ of $35^{\circ} \mathrm{C}\left(95^{\circ} \mathrm{F}\right)$ water to $29^{\circ} \mathrm{C}\left(85^{\circ} \mathrm{F}\right)$ at the design wet bulb temperature of $78^{\circ} \mathrm{F}$. A 60 horsepower motor drives the induced draft fan on the top of the tower. Circulating water is pumped through the condensers of the refrigeration machines and to the cooling tower by two centrifugal, horizontal shaft, split case, motor driven pumps rated at $1422 \mathrm{gpm}$ at 65 feet of developed head each.

The fan/coil units in the various buildings of the complex are controlled by individual thermostats which maintain the room air temperature at the desired level. The temperature of the chilled water is maintained at $6^{\circ} \mathrm{C}\left(42^{\circ} \mathrm{F}\right)$ by a control system which modulates Lhe refrigeration machincs and automatically starts and stops the second machine as the load varies. There is an interlocked control system which requires that the chilled water pumps, the circulating water pumps, and the cooling tower fan be in operation before the refrigeration machines can be started. Sensors and protective relays will stop the refrigeration machines if chilled water flow is lost or of the chilled water temperature drops too low.

The air conditioning system is manually activated in mid-May and turned off at the end of October by positioning two motor operated changeover valves (3-way). When they are in the cooling position, the hot water converter steam valve is closed.

\subsubsection{Room Heating and Domestic Hot Water Systems}

The space heating and domestic hot water heating fur the complex is satisficd by a low pressure steam system (Figure 2.6.4-1). Saturated steam at 15 psig is generated by two natural gas fired, fire-tube boilers located in the central energy plant. The steam is distributed to the complex by an underground pipe nctwurk. The steam supply and condensate return piping fnllow the same route as the cooling water lines as indicated in Figure 2.6.3-1. Each building has a steam/hot water converter which provides hot water to the fan/coil units for building heating and a hot water generator which supplies domestic hot water for general use. The condensate from the steam/hot water converter and hot water generator drains by gravity to a condensate return pumping unit in the equipment room of each building and is pumped back to the central energy plant via a condensate return pipe network. 

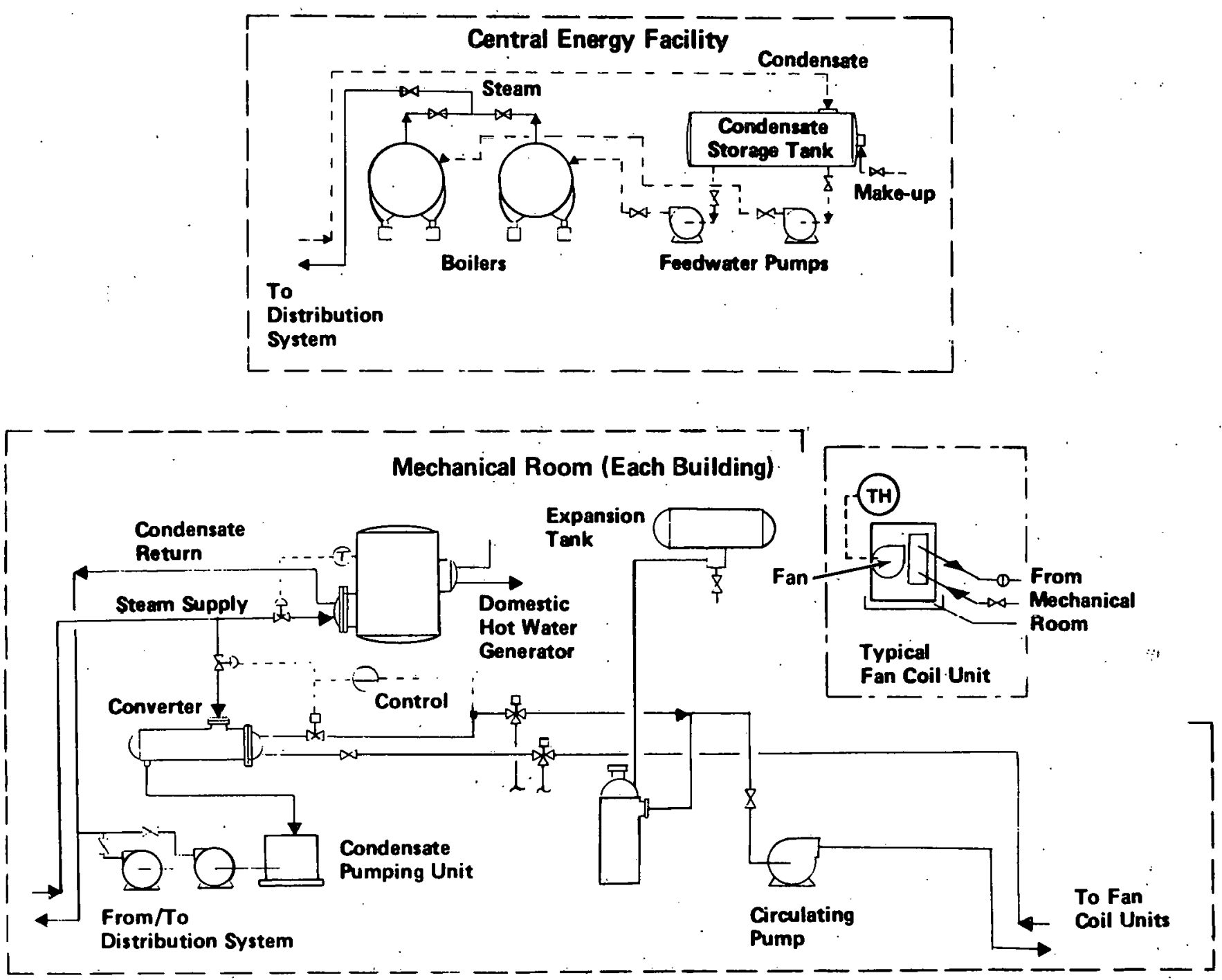

Figure 2.6.4-1. Existing Steam Generating Equipment for Space Heating and Domestic Hot Water

The central energy plant has a three-inch pipe supplying natural gas from a four-inch pipe which runs along the west edge of 15th Street. A pressure regulator is located at the outside of the central energy plant building which reduces the natural gas pressure from 10 psig to TBD.

The steam requirement for the complex is satisfied by two natural gas fired, fire-tube boilers. Each boiler rated at $11.7 \mathrm{million}$ BTU/hr can generate 12,075 pounds of 15 psig steam perhour. Boiler feedwater is pumped to the boilers from a common condensate return tank by two turbine type, motor driven pumps rated at $52 \mathrm{gpm}$. The flow of feedwater is controlled to maintain a set water level in the boilers. Make-up water from the potable water supply is 
piped to the condensate return tank and is controlled by a float valve. Boiler water quality is maintained by periodically blowing down the boilers to the sewer.

The two boilers are connected to a common manifold to which the complex steam distribution pipe and the central energy plant unit heaters are connected. The complex is supplied through a 10 -inch nominal pipe which is underground.

In each building the steam drives a steam/hot water converter rated between 884,000 and 1,195,000 BTU/hr. Water enters the converters and is heated to $82^{\circ} \mathrm{C}\left(180^{\circ} \mathrm{F}\right)$ and pumped to fan coil units providing space heating. Each circulating pump (also used for circulating cooling water) is rated between 235 and $335 \mathrm{gpm}$. The fan coil units, when used for space heating, can deliver between 6,500 and 17,250 BTU/hr. Converter control is accomplished by a twoway proportioning steam valve, positioned by an adjustable ratio reset control with one element in the supply water and one outside. A flow switch prevents opening the steam valve unless there is flow in the supply water line. The controls for the fan/coil units are locally mounted thermostats. In the Targer air handling units, a separate coit is provided for steam and for chilled water. Domestic hot water is provided by a 750 gallon hot water generator which uses steam to heat $4^{\circ} \mathrm{C}\left(40^{\circ} \mathrm{F}\right)$ water to $60^{\circ} \mathrm{C}\left(140^{\circ} \mathrm{F}\right)$. A twoposition steam valve is controlled by an adjustable thermostat. The condensate from the units drain by gravity to a condensate return pumping unit. Each unit has a pair of condensate pumps which operate alternately to pump the condensate at flowrates between 9 and $12 \mathrm{gpm}$ to the condensate return tank in the central energy plant. The return line size at the central energy plant is three-inch nominal pipe.

\subsection{EXISTIIIG PLANT PERFORMANCE}

\subsubsection{Energy Demands}

Estimates of the present monthly consumption of thermal energy for space heating and domestic hot water and electrical consumption per base loads and air conditioning were obtained from previous design reports on solar facilities at Complex 87000 (Reference 7). Discussions with DOD personnel at Fort Hood concerning operation of the heating and cooling system at Fort Hood have resulted in modifications to the cooling and heating load estimates presented. Originally, the barracks were designed to allow space heating or cooling as required when weather conditions vary. The present 
operating mode, however, consists of manual operation of control valves in each of the barracks' mechanical buildings to provide space heating from November through mid-May only and space cooling from mid-May through October only. The loads presented in Table 2.7.1-1 reflect the revised monthly and annual load estimated. The annual thermal requirement based on Table 2.7.1-1 is $9588 \mathrm{MWh}_{\mathrm{t}}$, not including boiler losses and $5137 \mathrm{MWh}$ for base loads and air conditioning. Hourly estimates of energy requirements of a typical day in each month were also developed using information presented in "Electricity and Natural Gas Consumption at Fort Hood, March 1975.". (Reference 13.) These profiles, after adjustment to match monthly energy requirements presented in Table 2.7.1-1; are shown in Appendix C. Additional data to substantiate these load estimates has been obtained from the Construction Engineering Research Laboratory (CERL) which performed an hourly survey of electric and gas usage at Complex 87000 from November 1976 to September 1978 under contract to the Army. Consumption data for days selected at random showed good agreement with the predicted load profiles.

Table 2.7.1-1. Fort Hood Estimated Energy Requirements

\begin{tabular}{|c|c|c|c|c|}
\hline Month & $\begin{array}{l}\text { Room } \\
\text { Heating }\end{array}$ & $\begin{array}{l}\text { Domestic* } \\
\text { Hot Water }\end{array}$ & $\begin{array}{c}\text { Electric } \\
\text { Base } \\
\end{array}$ & $\begin{array}{c}\text { Air Conditioning } \\
\text { Load }\end{array}$ \\
\hline January & $1334 \mathrm{MWh}_{\mathrm{t}}$ & $345 \mathrm{MWh}_{\mathrm{t}}$ & $253 \mathrm{MWh}_{\mathrm{e}}$ & $0 \mathrm{MWh}_{\mathrm{e}}:$ : \\
\hline February & 1087 & 315 & 228 & 0 \\
\hline March & 671 & 345 & 245 & 0 \\
\hline April & 403 & 335 & 239 & 0 \\
\hline Mạy & 149 & 345 & 246 & 336 \\
\hline June & 0 & 335 & 236 & 423 \\
\hline July & 0 & 345 & 246 & 515 \\
\hline August & 0 & 345 & 246 & 480 \\
\hline September & 110 & 335 & 235 & 242 \\
\hline October & 157 & 345 & 245 . & 241 \\
\hline November & .517 & 335 & 238 & 0 \\
\hline December & 1090 & 345 & $\underline{243}$ & 0 \\
\hline Total & 5518 & 4070 & 2900 & 2237 \\
\hline
\end{tabular}




\subsubsection{Availability/Outages}

An assessment of the annual operational time/availability of existing equipment at Fort Hood is underway and will be summarized in the final report. This assessment will cover the frequency and duration of both scheduled and unscheduled outages and major causes.

\subsubsection{Operation and Maintenance Requirements}

The assessment of the operations and maintenance (08M) labor and materials for the existing equipment at Fort Hood is underway and will be summarized in the final report. This effort will include O\&M experience to date and expected requirements over the equipment life cycle.

\subsection{PROJECT ORGANIZATION}

The MCDonnell Douglas Astronautics Company (MDAC) at Huntington Beach, California was the prime contractor for this effort. MDAC was supported by two principle subcontractors during the study period. The Stearns-Roger Company, Denver, Colorado determined the Fort Hood facility modifications required, defined plant support equipment, and provided additional support for development planning, costing, and the preparation of the System Specification. The University of Houston Energy Laboratory, Houston, Texas provided support for the optimization of the collector field. Figure 2.8-1 presents the study interface with the MDAC corporate structure and the study organization with key personnel and study responsibilities.

The U.S. Army organization at Fort Hood is shown on Figure 2.8-2. The overall responsibility for the integration of solar facilities into Fort Hood has been assigned to the Directorate of Facilities Engineering, under the direction of Col. R. E. Petty. Within his directorate, overall engineering liaison and support for the MDAC solar cogeneration study effort have been assigned to the Engineering Plans and Services Division, headed by Mr. O. R. H111. His division is responsible for civil architecture, inspection, master planning, mechanical-electrical, real property and facilities utilization aspects. A11 requests by MDAC for Fort Hood information and reviews. were coordinated through $\mathrm{Mr}$. Hill. 


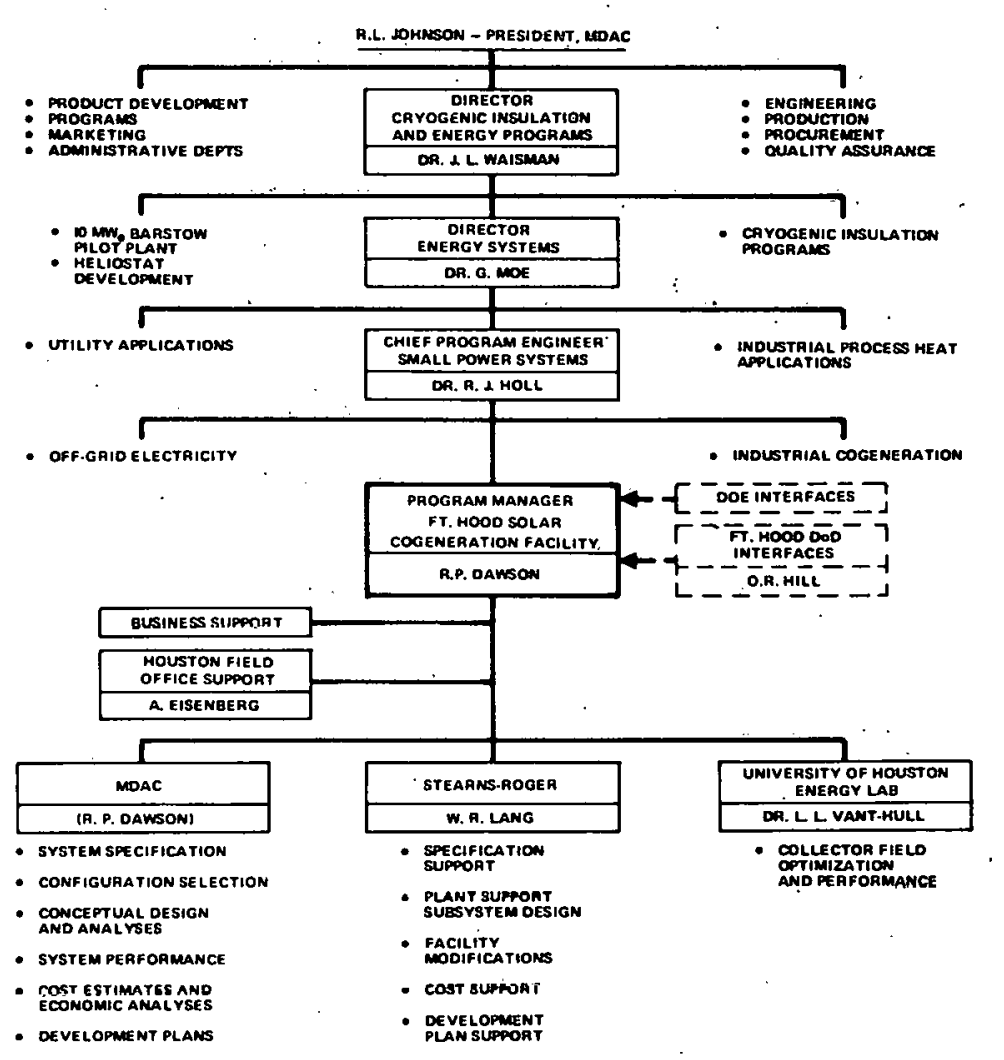

Figure 2.8-1. MDAC Study Organization

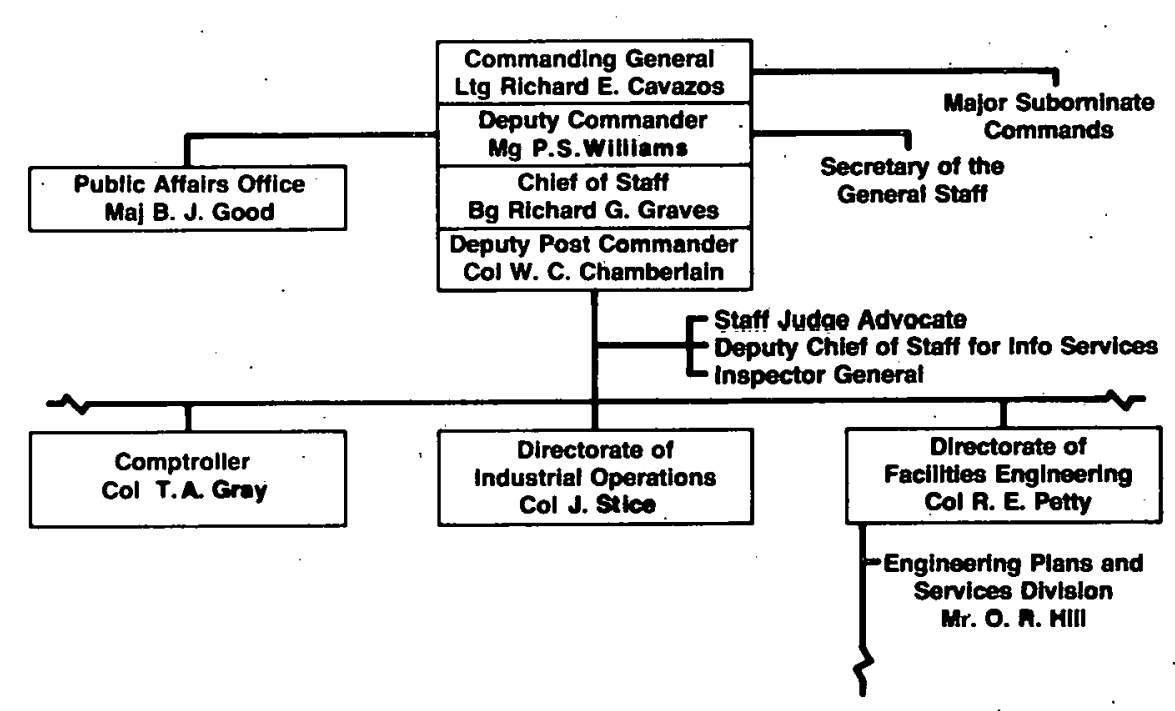

Figure 2.8-2. Fort Hood Organization 
The Directorate of Facilities Engineering, although under the command of the Fort Hood central headquarters, also coordinates directly with the Corps of Engineers, which is responsible for all U.S. Army fixed facilities and will ultimately be responsibie for the Fort Hood Solar Cogeneration Facilitv. It is expected that all facility cost estimates and analyses will be reviewed and all construction contracts will be eventually administered by the Fort Worth District Office of the Corps of Engineers.

\subsection{FINAL REPORT ORGANIZATION}

This report has been organized in accordance with DOE instructions and generally follows the study tasks. An Executive Summary and Introduction to the study are given in Section 1.0 and 2.0 , respectively. Section 3.0 (Selection of Preferred System) contains the results of all trade studies and initial sizing efforts leading towards the selection of the preferred site-specific system (Task 2). Section 4.0 (Conceptual Design) contains system-oriented facility conceptual design data (Task 3 ) including operating modes, functional requirements, supporting analyses, and facility performance estimates (Task 4). Section 5.0 (Subsystem Characteristics) contains the concept design description (Task 3 ) for each of the major subsystems. Section 6.0 (Economic Analyses) contains all facility cost estimates and economic analyses (Task 5). Section 7.0 (Development Plan) contains the initial plans for detailed design, construction and operational phases (Task 6). The System Specification (Task 1) is included as Appendix A to this report. The outline for the final report, as requested by $D O E$, has been included as Appendix B. Typlcal daily thermal demands of Complex 87000 for each month are given in Appendix $C$. 
Section 3.0

SELECTION OF PREFERRED SYSTEM

This section contains the results of Task 2 - Selection of Site-Specific Configuration. Contents of this section include candidate system configurations, technology assessments, system sizing, and the results of numerous trade studies leading towards the selection of the preferred system configuration. More detailed design, performance and economic information on the preferred system configuration is given in subsequent sections of this report.

\subsection{INTRODUCTION}

The overall objective of this task was to conduct engineering studies to establish concept feasibility and permit selection of a preferred configuration for further study. The scope of effort included a requirements review, site characteristics development, selection criteria development, candidate subsystem and system definitions, and system evaluation and selection. The task was initiated by a review of site-specific factors that affect the design and operation of the plant, such as the characteristics of equipment, facilities, and operations presently employed at Complex 87000 , site constraints, base regulations, etc. This information was gathered from a variety of sources including previous Fort Hood study resilts (references 3 through 8 ) and facility data.

Evaluation criteria for selection of the facility configuration were developed as shown on Table 3.1-1. These criteria were used to make quantitative (where possible) comparisons between alternative system, subsystem, or component features.

Candidate subsystems and major equipment elements were identified and appropriate ranges for design sizes, capacity, ratings, etc. were established. These candidate elements were then combined to form various system configurations and operating modes. Appropriate trade studies were conducted, as 
Table 3.1-1. Evaluation Criteria

- high economic value. concepts should be selected that provide high economic value in TERMS OF COSTS PER UNIT ENERGY USED AND NET PLANT hORTH.

- CRITICAL. FIEL SAVINGS/PERFORMANCE. SELECTED CONCEPTS SHOUL EXHIBIT REASONABLY HICH EFFICIENCIES IN SOLAR ENERGY COLLECTION AND THERMAL/ELECTRIC CONVERSION SO AS TO BE ECONOMICALLY COMPETITIVE WITH ALTERNATE ENERGY SYSTEMS AND RESULT IN SIGNIFICANT SAVINGS IN PETROLEUM AND NATURAL GAS FUELS.

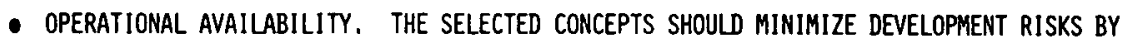
UTILIZING TECHNOLOGY AND DESIGN CONDITIONS THAT DO NOT REQUIRE SUBSTANTIAL DEVELOPMENT EFFoRTS OR FABRICATION PERIODS, THEREBY PROVIDING HIGH CONFIDENCE THAT THE SYSTEM CAN BE OPERATIONAL BY 1986.

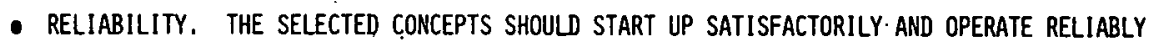
FOR A CONSIDERABLE. TIME PERIOD AFTER STARTUP WITH MINIMUM FURCEII OUTAGE DUE TO DESIGN DEFICIENCIES OR HARDWARE FAILURES.

- capital costs, concepts shovld be selected that minimize the capital costs of developing AND INSTALLING THE FACILITY, AND THE COSTS OF OPERATING AND MAINTAINING THE FACILITY.

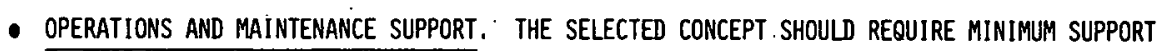
REQUIREMENTS WITH RESPECT TO ADDITIONAL EQUIPMENT, SPARE PARTS, MAKEUP FLUIDS AND ON-SITE CREW SIZE AND/OR SKILLS.

- Market potential/alternate apPlications. Selected CONCEPTS ShOUL be adaptable FOR OTHER EXISTING OR REE APPLICATIONS WITHOUT MAJOR DESIGN CHANGES OR EXCESSIVE CUSTOMIZING.

described in the following sections. An assessment of each candidate system was made with respect to the evaluation criteria, and a preferred sitespecific configuration and operating mode selected. This configuration served as the baseline for further conceptual design and analysis study efforts.

\subsection{SYSTEM CONFIGURATION}

\subsubsection{Configuration Options}

To initiate this effort, an initial baseline system configuration was established that was based on considerable precursor work by MDAC on small central receivertype solar systems. Aliternate system configurations were then developed for comparison to the baseline. The characteristics of the baseline system are summarized on Table 3.2.1-1 with an indication of the fixed and variable elements that were investigated for the alternate system concepts. As indicated, fixed items included the heliostat design, collector field type, collection and storage fluid, receiver design concept, high temperature storage fluid, receiver design concept, high temperature storage fluid, receiver design concept, high 
Table 3.2.1-1. System Configuration Options

\begin{tabular}{|c|c|c|c|}
\hline IIEUI & BASELLIIE SYSTEM & ALTERIIATE SYSTEIS & VARIABLES \\
\hline - HELIOSTATS & SECONI) GEHERALION & (ildile) & RUMBER \\
\hline - collector field & HORTH FIELD & (NONE) & HELIOSTAT LOCATIONS \\
\hline - TOHER & GUYED & EBEE-STAIDDUG & HELIOSTAT LOCATIONS \\
\hline - arcejver & PARLIAL CAVITY & (MONE) & SIZE, FLOH RATE \\
\hline - HE:T TRIISFER FLLID & HLECC & (HONE) & OPERATING TEMP. \\
\hline - Vil:ii TE'IP. STORAGE & HIIEC, DUAL TAUKSS & $\cdot$ (HONE) & CAPACITY, TEMP. \\
\hline - fuUX. heater & HIIEC,_IATLRAL GAS & (IIO'IE) & CAPACITY, ṪEMP. \\
\hline STEAN GEIIERATOR & OHCE-THROUGH: & REBOILER (KETTLE) & CAPACITY, TE'P. \\
\hline
\end{tabular}

NOTE: SELECTED COIPOMEITS ARE UNDERLINED

temperature storage concept, and air conditioning equipment type. Candidate components for the alternate systems are reviewed in Section 3.5, Trade Studies.

\subsubsection{Preferred System Concept}

A preferred system configuration for the Fort Hood solar cogeneration facility was selected as a result of this task. Major components of the selected system are summarized on Table 3.2.2-1, and also are the items underlined on Table 3.2.1-1. The evaluation criteria summarized in Section 3.1 were used in the selection process for the elements and overall system configuration.

Table 3.2.1-1. System Configuration Options (Cont)

IEI

- tUBine/generator BASELIME SYSTEM

IUULTI-STAGED RAIKINE (EXTRACTION)

- OPERATIIIG IIODE

OII/OFF

- air conditioner ABSORPIIOII CHILER

- chilled hiter STURAGE \& DISTRIBUTION

- HeAl DISTRIBUTION SIEAN

- Loh tehap storage - hot hiter, DISTRIBUTEU

- plint control seni-automatic

NOTE: SELECTEU CONCEPTS ARE UHDERLINED

CHILLED WATER, DISTRIBUTED

\section{ALIERIAIE SYSTEMS}

SILILLE-STAGE RANKINE (BACK PRESSURE)

CONTINUOUS; POHER/IDLE

(NOME)

CHILLED HAIER, CENTRALIZED

HOT :IATER

HOT HATER CFHTRALIZED BRESSURIZED HATER, CEETRBAL

FULLY AUTOHATTIC
VARLABLES

POHER RATIIIG, TEMP, PRESSURES, FLOH RATE

PONER SETTINGS

CAPACITY, TEIP, PRESSURE

CAPACITY, TEMP, PRESSURE

FLOH RATE, TEHP, PRESSURE

CAPACITY, TERP, PRESSURE

EQUIPMENT TYPE, COHPLEXITY, SAFETY 
Table 3.2.2-1. Preferred System Configuration

- heliostats

- tower

- receiver

- heat tRanSFer fluid

- storage tanks

- aux. heater

- steam generator

- turbine

- generator

- air conditioner

- chilled water storage

- LOW TEMP. STORAGE

- ENERGY DISTRIBUTION

- plant control
MDAC 2ND GEN, $242\left(56.84 \mathrm{M}^{2}\right.$ EACH)

FREE STANDING STEEL, 54 M (177 FT)

PARTIAL CAVITY, $5.0 \mathrm{~m}(16.4 \mathrm{FT})$ APERTURE.

HITEC, $260{ }^{\circ} \mathrm{C}\left(500^{\circ} \mathrm{F}\right)$ To $454^{\circ} \mathrm{C}\left(850^{\circ} \mathrm{F}\right)$

TWO TANKS (HOT, COLD) $20 \mathrm{MW}_{\mathrm{TH}}$

STRUTHERS WELLS GAS FIRED HITEC HEATER, $5.9 \mathrm{MW}_{\mathrm{T}}$

STRUTHERS WELLS REBOILER (KETTLE) $6.3 \mathrm{MW}_{\mathrm{T}}$

TRANE TMG SINGLE STAGE, $656 \mathrm{KW}$ (880 HP)

IDEAL, $600 \mathrm{KW}$

TRANE ABSORPTION CHILLER, 800 TON

CENTRALIZED STORAGE TANKS (2), $7.5 \mathrm{MW}_{\mathrm{T}} \mathrm{H}$

CENTRALIZED PRESSURIZED WATER TANKS (2), 5.0 $\mathrm{MW}_{\mathrm{T}} \mathrm{H}$

EXISTING STEAM AND CHILLED WATER LINES

SEMI-AUTOMATIC

Special emphasis was given to the selection of operational modes and available equipment that minimize the life cycle costs, the development risks, and the modifications to the existing facilities at Fort Hood.

A preliminary flow schematic of the preferred concept is shown on Figure 3.2.2-1. A design description of the complete system will be given in Sections 4 and 5 of the Final Report.

\subsection{TECHNOLOGY}

\subsubsection{System Development Risk Assessment}

The system evaluation criteria summarized on Table 3.1-1 includes two items of particular importance relative to system development risk assessment operational availability and capital costs. With respect to development risk, the selected concepts should minimize development risks by utilizing technology and design conditions that do not require substantial development efforts or fabrication periods, thereby providing high confidence that the 


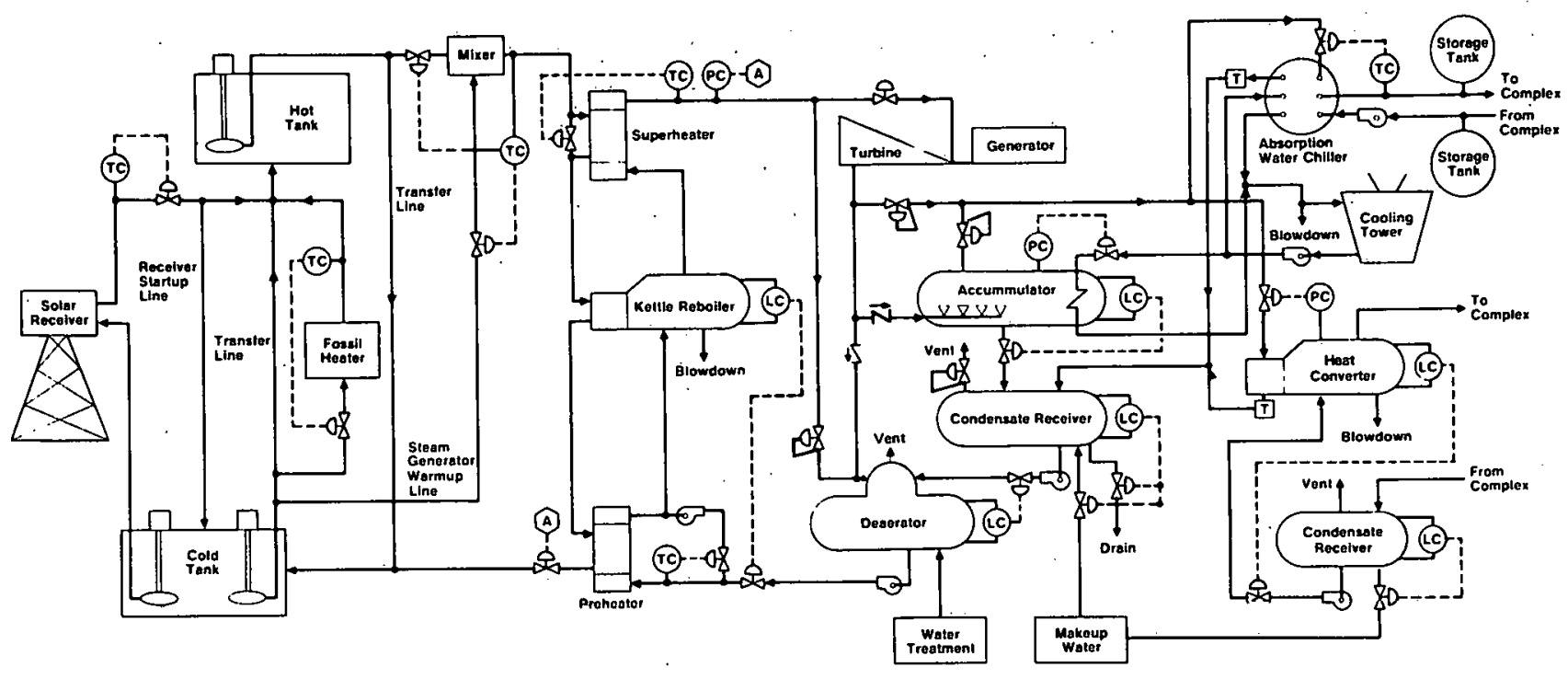

Figure 3.2.2-1. Fort Hood Preliminary Piping and Instrumentation Drawing

Table 3.3.1-1. System Development Risk Assessment

\begin{tabular}{|c|c|c|}
\hline SUBSYSTEM COMPONENT & $\begin{array}{l}\text { EXISTING EQUI PMENT } \\
\text { STATE-OF-THE-ART }\end{array}$ & $\begin{array}{l}\text { ON-GOING } \\
\text { AND TESTIN }\end{array}$ \\
\hline - hel IOSTATS & $x$ & \\
\hline - tONER & $x$ & \\
\hline - RECEIVER & & $x$ \\
\hline - RECEIVER FLUID & $x$ & \\
\hline - HIGH TEIP STORAGE & $x$ & \\
\hline - AUXILIARY heAtER & $x$ & \\
\hline - TURB INE/GENERATOR & $x$ & \\
\hline - air conditioner & $x$ & . \\
\hline - CHILLED WATER StORAGE & $x$ & \\
\hline - LO'N TEMP StORAGE & $x$ & \\
\hline - plant control & $x$. & \\
\hline - BaLAiilce of PLANT & $x$ & \\
\hline
\end{tabular}

ADDITIONAL TESTING REQD

system can be operational by 1986. With respect to capital costs, the concepts should be selected that minimize the capital costs of developing and installing the facility, and the costs of operating and maintaining the facility.

For these reasons, heavy emphasis was placed on the use of existing equipment and state-of-the-art technology for the necessary components and subsystems 
of the solar cogeneration system. This has the added benefits of improving system reliability, which is also an important evaluation criteria.

A summary of the development status. of the key components is given on Table 3.3.1-1. As can be noted from this summary, most of the items require no development testing. These items are either existing (with little or no modifications) or are based on existing and well proven design approaches. The only item that may require some additional development testing is the receiver, which is reviewed below in Sections 3.3.2 and 3.3.3.

\subsubsection{Receiver Fluid Risk Assessment}

In previous studies conducted by MDAC on small solar central receiver systems (references $21,22,23$ ), an extensive survev was made of candidate receiver fluids which included salt solution, superheated and saturated steam, organics, syltherm, and liquid sodium. A summary of the major advantages and disadvantages of these fluids is given on Table 3.3.2-1. The heat transfer media selected from these previous efforts and used as the baseline for the Fort Hood Solar Cogeneration. Facility study is a molten salt solution termed "HITEC." HITEC is an eutectic mixture of potassium nitrate $53 \%$, sodium nitrite $40 \%$, and sodium nitrate $7 \%$. Properties of HITEC are given in Section 5 of the System Specification.

HITEC was developed in the 1930's by DuPont Chemical Company, and has been used safety in numerous world-wide applications in the chemical, petroleum, and metal treatment industries. In the majority of applications, HITEC is used as a heat recovery fluid in which it is pumped from a salt tank, through a reactor where it picks up heat from exothermic reaction, into a steam generator to be cooled, and back to the tank to be recylced.

HITEC is used because it has a relatively low melting point, high heat transfer coefficient, thermal stability, and low cost. HITEC is a white granular solid which turns yellow when heated. It is nonfouling, nonflammable, nonexplosive and evolves no toxic vapors under normal conditions. It has a low degree of corrosivity and can be used with carbon steel up to $454^{\circ} \mathrm{C}\left(850^{\circ} \mathrm{F}\right)$. Maximum operating temperature is $538^{\circ} \mathrm{C}\left(1,000^{\circ} \mathrm{F}\right)$. . The vapor pressure below 


\begin{tabular}{|c|c|c|}
\hline FLUID & MAJOR ADVANTAGES & MAJOR DISADVANTAGES \\
\hline - HITEC/HTS & $\begin{array}{l}\text { COMMERCIAL HEAT } \\
\text { TRANSFER FLUID } \\
\text { GOOD PROPERTIES }\end{array}$ & $\begin{array}{l}\text { FREEZING TEMPERATURE } \\
\text { OF } 142^{\circ} \mathrm{C}\left(288^{\circ} \mathrm{F}\right)\end{array}$ \\
\hline - SUPERHEATED STEAM & STATE-OF-THE-ART & $\begin{array}{l}\text { TURBINE BUFFERING } \\
\text { STORAGE } \\
\text { EQUIPMENT AVAIL. }\end{array}$ \\
\hline - SATURATED STEAM & SIMPLE SYSTEM & HIGH STORAGE COST \\
\hline - ORganics & $\begin{array}{l}\text { COMMERCIAL HEAT } \\
\text { TRANSFER FLUID }\end{array}$ & $\begin{array}{l}\text { LIMITED TEMP. } \\
\text { CAPAB ILITY; FLUID } \\
\text { MAINTENANCE REQUIRED }\end{array}$ \\
\hline - SYLTHERM & $\begin{array}{l}\text { HIGHER PERFORMANCE: } \\
\text { CAPAB ILITY THAN } \\
\text { ORGAN ICS }\end{array}$ & HIGH COST \\
\hline - LIQUID SODIUM & BEST COOLANT & $\begin{array}{l}\text { HIGH EQUIPMENT } \\
\text { COST/HAZARDS }\end{array}$ \\
\hline
\end{tabular}

$450^{\circ} \mathrm{C}$ is essentially zero. Although very stable up to high temperatures, the salt undergoes a slow thermal breakdown of the nitrite to nitrate. In contact with air, the nitrite is slowly oxidized by atmospheric oxygen. Carbon dioxide can be absorbed to form carbonates and water to form alkali metal hydroxides. These reactions tend to raise the freezing point and are essentially eliminated by using a nitrogen cover gas. Using nitrogen as a cover gas will give maximum control of side reactions resulting in minimal salt replacement:

The majority of chemical and petroleum process industries using HITEC operates below $450^{\circ} \mathrm{C}\left(842^{\circ} \mathrm{F}\right)$ and uses carbon steel exclusively with no unusual corrosion problems. Corrosion rates on carbon steel are on the order of 0.1 to $0.4 \mathrm{~mm} / \mathrm{yr}$ between $450^{\circ} \mathrm{C}\left(842^{\circ} \mathrm{F}\right)$ and $521^{\circ} \mathrm{C}\left(970^{\circ} \mathrm{F}\right)$. Above $450^{\circ} \mathrm{C}\left(842^{\circ} \mathrm{F}\right)$, stainless steel has been used with minimal corrosion problems.

In summary, the use of HITEC as the receiver fluid is considered to be a very low risk application for the Fort Hood solar cogeneration facility, especially at the low operating temperatures proposed. 


\subsubsection{Receiver Configurations Risk Assessment}

Receiver configurations for small central receiver solar system have been under investigation by MDAC for several years. Company-funded efforts are continuing to further develop conical-cone type and other receivers configurations for multiple applications, including utility power plants, enhanced oil recovery, and small cogeneration systems, both in the United States and abroad. Results of these past efforts have been published in numerous reports and papers (References $21,23,25,26,27,28$ ). The receiver configurations investigated for small solar systems have included the following:

- Single Zone - Flat panel with serpentine flow

- Dua1 Zone - Flat front panel of spaced tubes partially shading a back panel of packed tubes

- Spiral zones - Spiral tubes in a flat profile

- Cavity - Spiral tubes in a conical profile

- Partial Cavity - Spiral tubes in a multiple conical profile

Results of much of the design and analyses leading towards the selection of the partial-cavity configuration for small solar systems using molten salt, were presented in Reference 23. For the Fort Hood application, a partial-cavity type receiver with spiral tubes has been selected for the conceptual design effort. This receiver concept is briefly described in Section 3.4.1.

Molten Salt receiver tests are currently underway at the Sandia Central Receiver Test Facility (CRTF) in Albuquerque, New Mexico. These tests are being conducted on a single-zone vertical serpentine tube configuration using molten salt up to $566^{\circ} \mathrm{C}\left(1050^{\circ} \mathrm{F}\right)$. No major design or operational problems have yet been experienced. The results from these tests are being used as much as possible in the conceptual design of the Fort Hood receiver, however, the Fort Hood design is a partial cavity configuration which is expected to yield improved performance capabilities. Additional tests on such a partial cavity configuration may be required to verify estimated performance capabilities. However, the development risks associated with the design and operation of a partialcavity receiver with molten salt are expected to be minimal, and testing to prove design feasibility is not considered to be necessary. 


\subsection{SYSTEM SIZING}

\subsubsection{Collector Field Sizing}

The collector field was sized to:

1. Provide the desired annual solar energy to the cogeneration facility.

2. Fit in the available land area

3. Accomplish 1 and 2 in the lowest cost configuration.

In Section 3.4.2, the Solar System Sizing requirements are discussed. Various combinations of turbine rating, high and low temperature storage, and operating modes were evaluated. The results of this analysis indicate that the maximum solar benefit is realized for a solar system producing $13.7 \mathrm{GWh}_{\mathrm{t}} /$ year. Thus, this was the annual energy requirement used for the collector field optimization effort.

Based on detailed drawings for Complex 87000 (Reference 17), it was determined that the collector field would be located directly east of the complex in the area bounded by Battalion Avenue to the south, 15th Street to the west, and Martin Drive to the east. Currentiy, plans exist to extend Central Avenue from 15th Street to Martin Drive, forming the northern field boundary. An existing parking lot and park east of 15 th Street will be removed and relocated. The total land area enclosed by the roads is $61,990 \mathrm{~m}^{2}(15.3$ acres).

The collector field also imposes perimeter constraints on the land area. First, a security fence is required around the field. Next, a service road inside the fence and around the perimeter of the heliostats is necessary for operation and maintenance procedures. This service road must have adequate clearance between the fence and heliostats when the heliostats are in an extreme position (perpendicular to the road). The service road must also provide access to the tower and the main roads. Finally, the tower must have adequate clearance with the serurity fence, Figure 3.4.1-1 shows these field perimeter constraints. The following guidelines were established: 


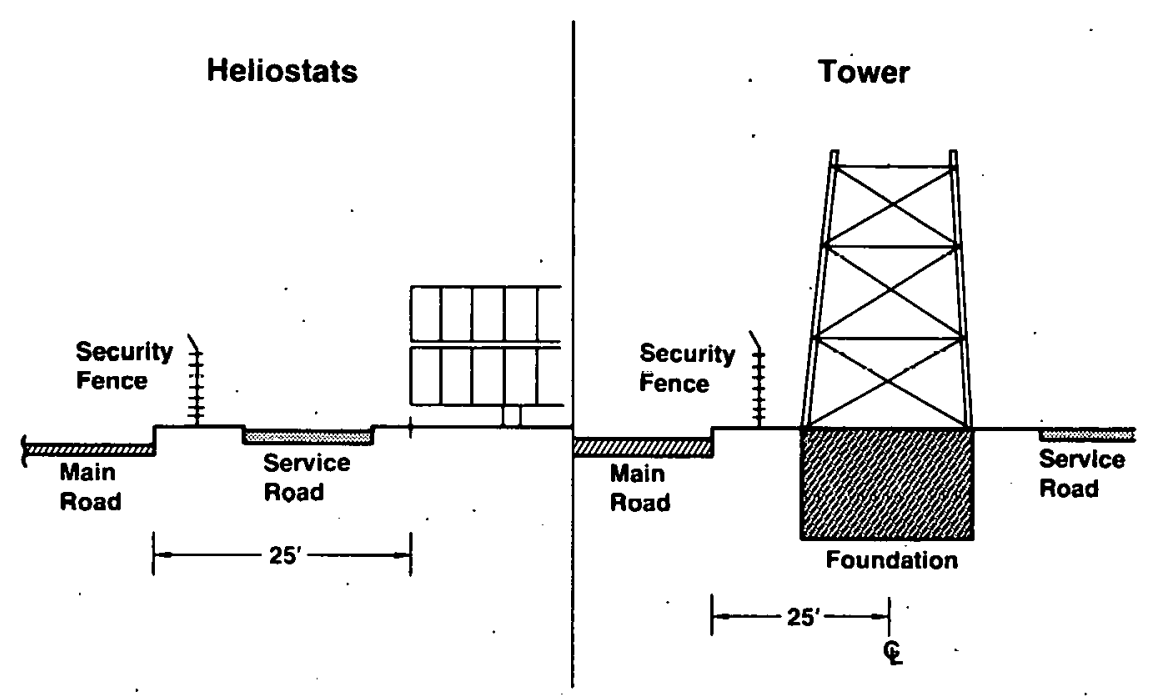

Figure 3.4.1-1. Field Perimeter Constraints

1. The security fence will be located $1.52 \mathrm{~m}(5$ feet $)$ from the main road edges.

2. The service road will be $3.7 \mathrm{~m}$ (12 feet) wide. It will have $1.52 \mathrm{~m}$ (5 feet) of clearance with the fence and $0.9 \mathrm{~m}$ ( 3 feet) of clearance with a heliostat turned perpendicular to the road.

3. The tower base is assumed to be approximately $9.1 \mathrm{~m}$ (30 feet) square. The tower will have $1.52 \mathrm{~m}$ ( 5 feet) of clearance with the fence.

Thus, the heliostats and the centerline of the tower must all be contained in an area that is $7.6 \mathrm{~m}$ (25 feet) in from the road edges. The constrained field area is $54,147 \mathrm{~m}^{2}(13.4)$. acres.

The collector field optimization analys is was carried out by the University of Houston using the well established R-cell and NS computer codes (References 18 \& 19) which have been exercised extensively in support of other DOE contracts. The objective of the codes is to determine the most cost effective approach to the gathering and delivery of annual thermal energy to the base of the tower. The resulting subsystem characteristics are dependent on the nature of the inputs assumed for the analysis.

Before initiating the optimization procedure, the collector field was divided into a number of computational cells. In this case, 12 rows and 10 columns were used (rows run west to east and columns north to south). A performance 
data base was established for each cell containing annual cell performance information as a function of heliostat spacing. The performance information reflects cosine, shading, and blocking efficiencies. The data are used as input to the optimizer.

The optimizer requires as an input a figure of merit based on the expected total cost of the field, including the tower, receiver, etc., divided by the annual collected energy. From this, a cell matching parameter is formed based on the ratio of heliostat cost to input figure of merit times annual available energy. For each cell, the optimizer locates all possible values of heliostat spacing which will satisfy the cell matching parameter. The optimizer also locates all values of heliostat spacings which will maximize the production of energy from each cell. The optimal heliostat spacings satisfy both of the conditions, thus minimizing cost and maximizing energy.

The optimizer compares the product of annual energy contributed by the cell and cell intercept fraction to the cell matching parameter. As long as the product is greater than the cell matching parameter, the cell is not degrading the figure of merit and stays in the field. If it is less, the cell is trimmed from the field. Thus, the field boundary is formed. Once the optimal heliostat spacings and field boundary are determined, the number of heliostats in each cell can be determined and a new output figure of metit is formed. Use of the cell matching parameter in defining the heliostat separation and in determining the field boundary assures that each cell is contributing to the system performance in a cost optimal way.

For systems that are not land constrained, the above process is repeated, and the point where the input figure of merit and output figure of merit converge defines the optimal collector field.

For Fort Hood, there is a firm fixed field boundary. In this case, a tower height was selected, and the optimizer was used to define the best system for that tower height. Then the input figure of merit was reduced to "spread out" the heliostats within the field boundary. This was repeated for tower heights between $48 \mathrm{~m}$ and $60 \mathrm{~m}$, recognizing that for the land constrained case, the final tower height would be somewhat higher than for the unconstrained land case. 
Implicit in the figure of merit are the influences of all cost and performance considerations which can be allocated to the individual heliostats. These factors include:

1. Shading and blocking of adjacent heliostats

2. Guidance error model

a. Slope errors of reflectors

b. Tracking errors

3. Aberration model for canted heliostats

4. Heliostat aim strategy

5. Cost model

a. Heliostats (including guidance, etc.)

b. Tower

c. Receiver

d. Plumbing in tower

e. Land for heliostat

f. Wiring for heliostat

g. Receiver feed pump

6. Energy loss model

a. Mirror reflection and receiver absorption

b. Receiver absorptivity versus angle of incidence

c. Reradiation and convection from receiver

d. Atmospheric losses between heliostat and receiver

e. Interception losses at receiver

The information developed as a result of this optimization analys is includes a specification of the optimized cost of annual energy, the annual energy absorbed into the receiver working fluid, the peak power level, field shape. and heliostat spacing data for each of the computational cells selected for use. A simple change in tower height (expressed in terms of revised interception factors) and the corresponding cost scaling will result in a new set of collector subsystem performance and design data. This process was repeated until a sufficient parametric data base was established to cover the range of interest from 13.5 to 14.0 GWh of annual thermal energy.

To carry out the field optimization, inputs were provided to the University of Houston regarding the heliostat, tower, and receiver designs, along with 
cost algorithm and the present value of 0\&M for each. Brief reviews of these inputs are given below.

\section{Heliostats}

The heliostats used for the collector field sizing effort were based on the MDAC Second Generation Heliostat design as shown on Figure 3.4.1-2 and described in Reference 20. This advanced heliostat is the result of a product evolution blending important design innovations with basic concepts thoroughly proven in testing and actual operation.
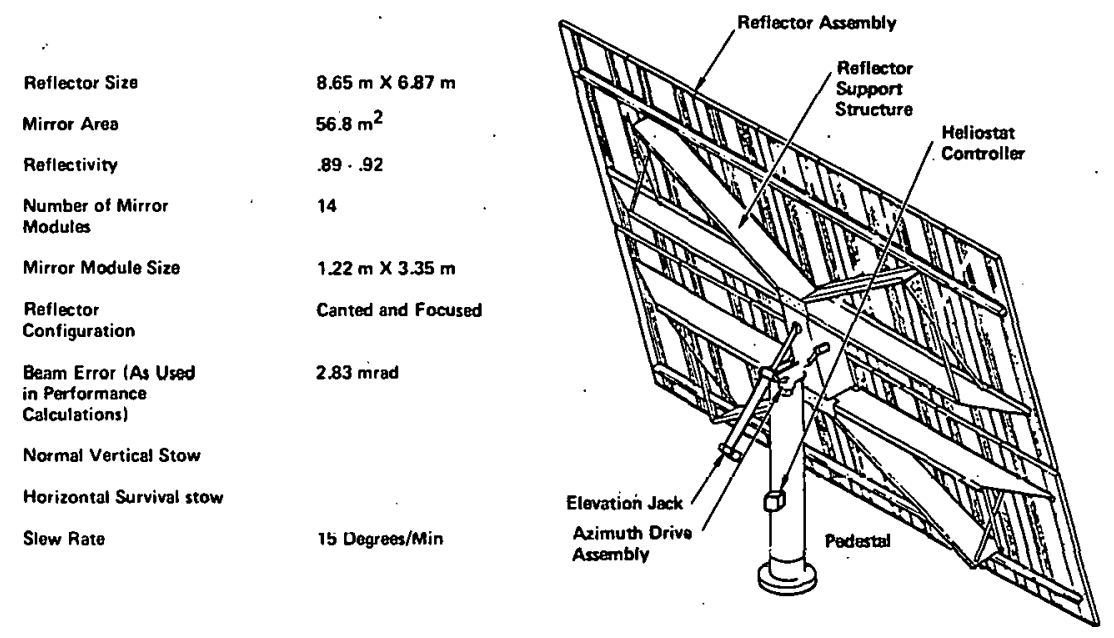

Figure 3.4.1-2. MDAC Second Generation Heliostat

A major design change from earlier concepts is vertical stowing of the heliostat, with face up, or horizontal, survival against extreme storms. This single basic change not only reduced the weight of required drive hardware by 350 pounds, this cutting fabrication cost, but also added $20 \%$ more reflective area to each heliostat without any increase in overall drive unit size.

Other related improvements include a higher aspect ratio providing decreased blocking and shadowing, and a better packing fraction.

Significant cost reductions in field installation are achieved by providing the basic heliostat system in three factory assembled prealigned units. These include the drive assembly, consisting of the main beam, azimuth and elevation drives, pedestal, and heliostat controller; and two reflector assemblies, each consisting of support structure and seven mirror modules. 
Design details of this heliostat will be presented in Section 5.1 of the Final Report and Section 5 of the Final System Specification.

Tower

Land constraints on the field would not allow the effective use of a guyed steel tower. Thus, a free-standing steel tower was selected for the conceptual design as shown on Figure 3.4.1-3. Preliminary tower design and cost algorithms were transmitted to the University of Houston for the collector field optimization analysis.

Designs details of the tower will be given in Section 5.3 of the Final Report.

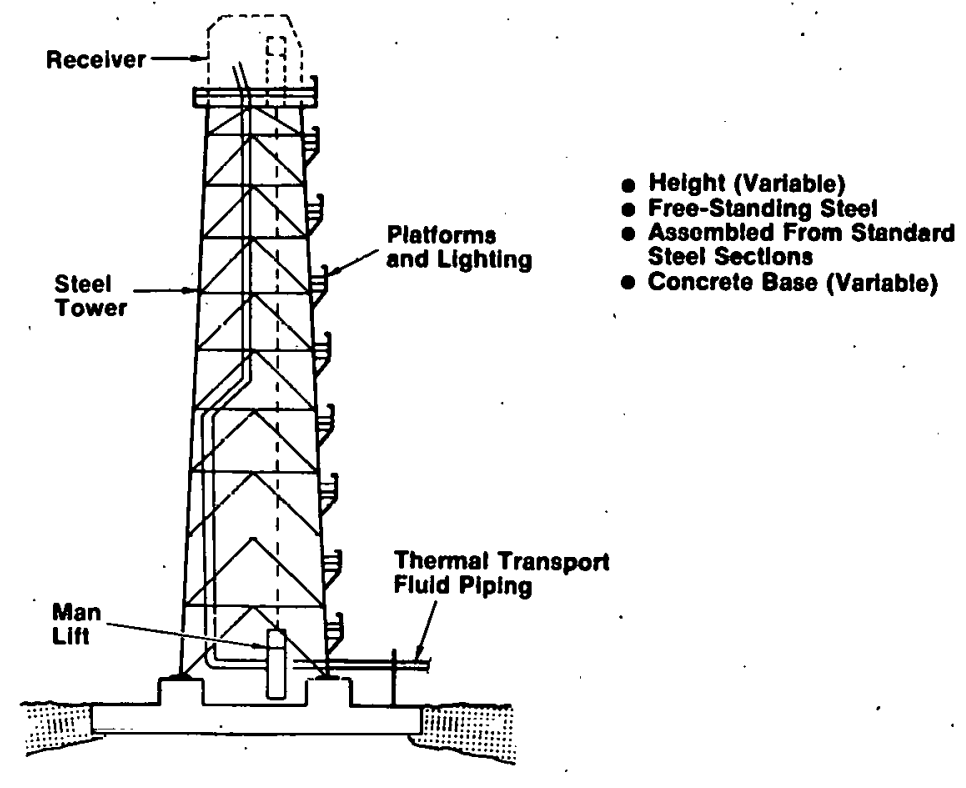

Figure 3.4.1-3. Tower Subsystem

\section{Receiver}

The receiver design to be used for the conceptual design is a partial cavity configuration having a circular external aperture and a conical cavity section, as illustrated in Figure 3.4.1-4. This reçeiver design is the same design as that presented in Reference 23 .

The University of Houston was instructed to treat the receiver as a flat plate with a circular aperture. A single point aim strategy was specified for the purpose of selecting the minimum aperture size. The receiver performance was given with respect to aperture area. The thermal loss is 


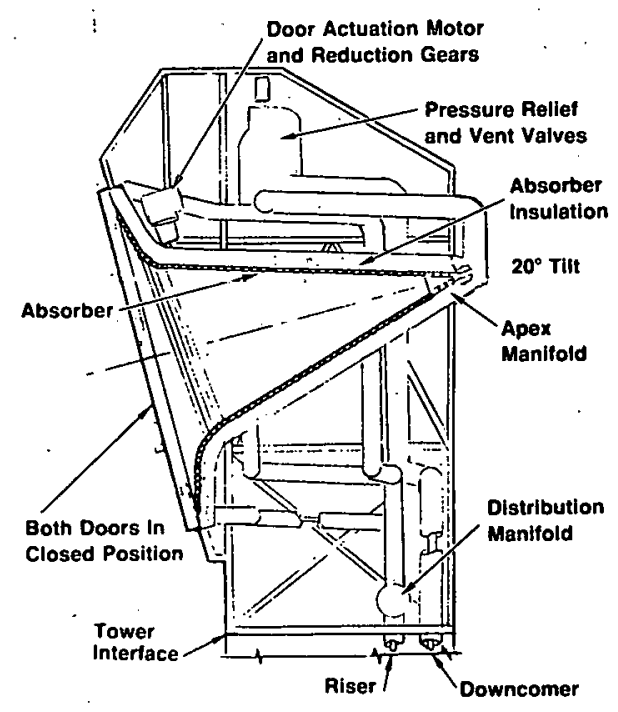

Figure 3.4.1-4. Receiver Configuration

$21.4 \mathrm{kw} / \mathrm{m}^{2}$ aperture and the effective absorptivity is .960 . These values are based on previous MDAC design studies using the conical partial cavity receiver.

The receiver design imposes another restriction on the collector field boundaries. The partial cavity configuration has a junction of the external absorber portion and the cavity absorber portion. The azimuthal extent of the field filust be 1 imited to $105^{\circ}$ to avoid excessive incident flux at this junction. Heliostats beyond an azimuth angle of $52.5^{\circ}$ from the field centerline "see" this junction point almost directly normal. The receiver aperture area projection for these heliostats is such that their aim points cannot be moved far enough to reduce excessive flux without suffering very high spillage. Thus, the University of Houston was instructed to limtt the cullector field total azimuth angle to $105^{\circ}$.

\section{Cost Algorithms}

Cost. algorithms were provided to the University of Houston for the collector field optimization analysis. These cost data were supported by data from previous MDAC studies. The major input cost parameters which include the heliostats, tower, receiver, feed pump and vertical plumbing, are shown on Table 3.4.1-1. 
Tabie 3.4.1-1. Cost Parameters

- Heliostats

Tower

Receiver

Feed Pump

Vertical Plumbing
$\$ 266 / M^{2}$

$384,000+260 \times$ (Tower Height) 1.4

$1.4 \times 106\left(\frac{\text { Design Power }}{6.4}\right) .57$

$16,000\left(\frac{\text { Tower Height }}{40}\right) \cdot 65\left(\frac{\text { Design Power }}{7.0}\right)^{.65}$

$8.310\left(\frac{\text { Tower Height }}{54.9}\right)\left(\frac{\text { Design Power }}{9.0}\right)^{.5}$

The field optimization analysis results, which are shown on Figure 3.4.1-5, indicate that for an annual energy of 13.5 to $14.0 \mathrm{GWH}_{t}$, the optimum tower height is approximately $54 \mathrm{~m}$ (optical). For the desired annual energy of $13.7 \mathrm{GWh}_{t}$ the "best" system is the one having a 650 input figure of merit as shown on Figure 3.4.1-5. However, the optimization curve for the 54 meter tower indicates that a system with an input figure of merit of 750 has the same output figure of merit, but packs slightly more heliostats into the field providing more annual energy. Because of the firm fixed field boundaries, and in order to provide some growth potential for uncertainties, it was decided to use this latter system for the conceptual design. Hence, the selected system contains 250 heliostat positions, which is slightly more than is required for the desired annual. energy. Thus, there will be 250 foundations in the field, but only 242 will be occupied by heliostats for conceptual design purposes. The annual energy of the cogeneration facility could be increased by $3 \%$ at a later date, if needed, by installing the additional heliostats. This could be done without affecting any other heliostat spacings in the field.

Figure 3.4.1-6 shows the results of the receiver aperture sizing analysis. A minimum receiver aperture of $4.5 \mathrm{~m}$ ( 14.8 feet) diameter gives the best 


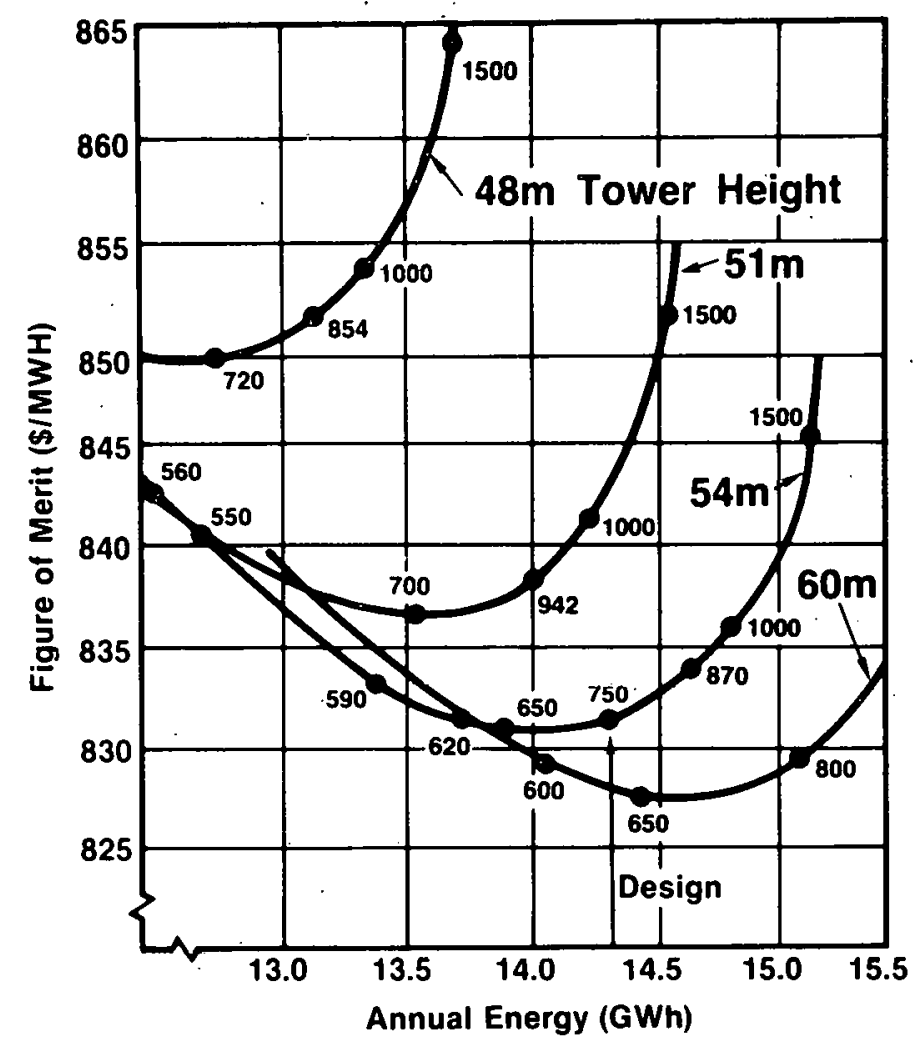

Figure 3.4.1-5. Field Otpimization Results

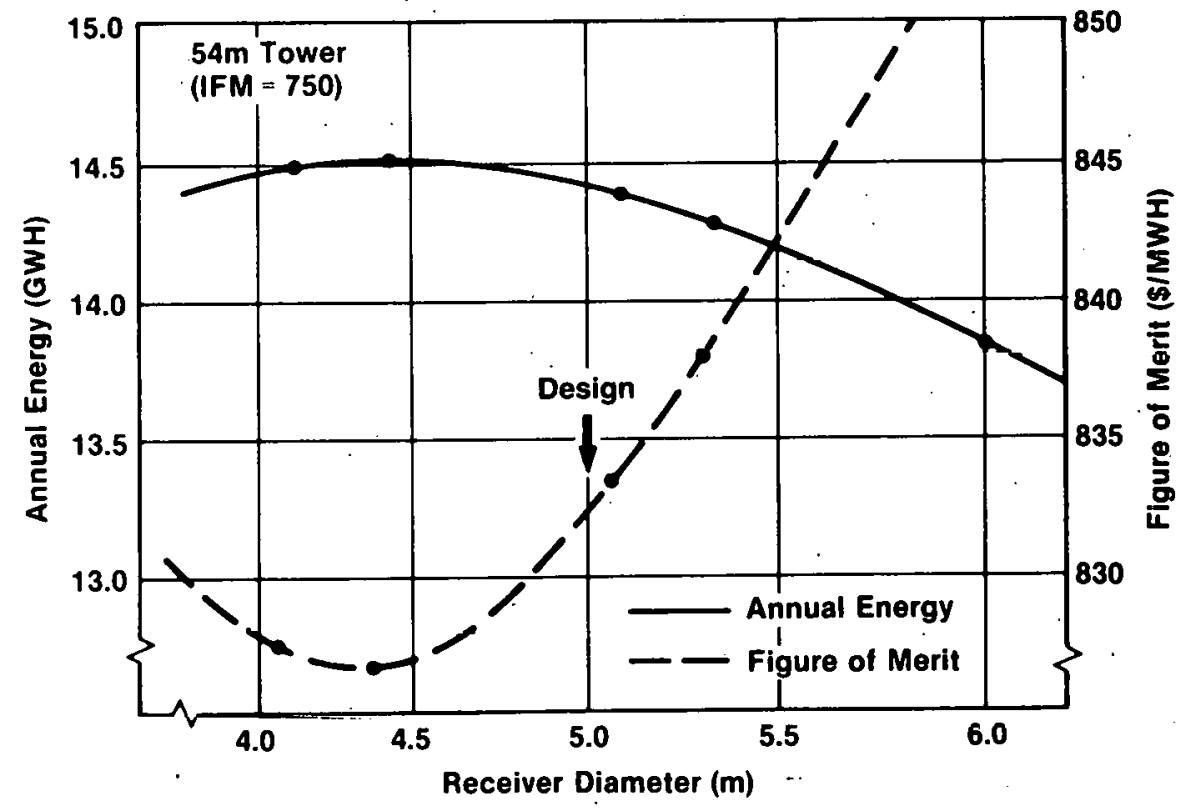

Figure 3.4.1-6. Receiver Aperture Sizing 
figure of merit. However, this analys is was done for a single point of strategy. Previous studies conducted by MDAC indicate that the optimal aim strategy wi11 be a separate aim point for each heliostat.

The aperture is sized by the furthest heliostats from the tower. These heliostats will be aimed at the center of the aperture. To minimize spillage, the aperture will have to be slightly larger than the image from these distant heliostats. In past MDAC studies, this approach has yielded a peak flux of $0.4 \mathrm{mw} / \mathrm{m}^{2}$, with a peak-to-average flux ratio of 1.9:1.0, and spillage of less than $3 \%$. Consequent1y, the aperture size for the conceptual design has been selected to be a $5.0 \mathrm{~m}$ (16.4 feet) diameter.

Figure 3.4.1-7 shows the resulting north field configuration that was optimized by the University of Houston analysis. The cell structure runs north/south and east/west. The field boundaries, $105^{\circ}$ azimuth constraint, tower location, and optimum number of heliostats in each cell are shown.

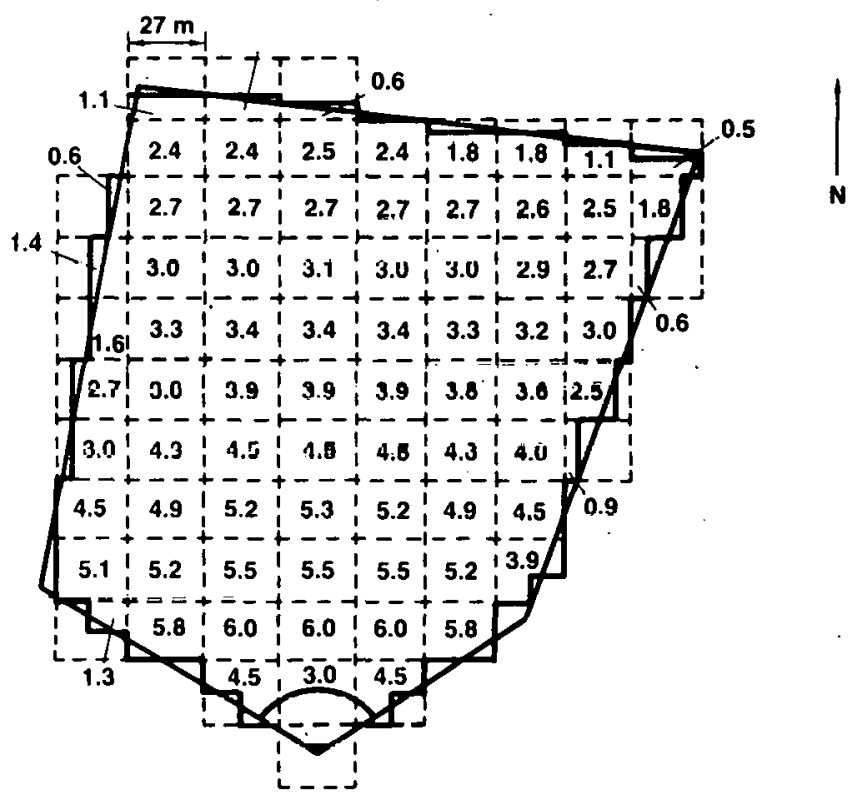

Figure 3.4.1-7, Fort Hood Collootor Ficld Layout With Imposed Field Boundaries

Figure 3.4.1-8 presents a performance summary chart for the design point. (clear day at noon on Fall Equinox). This "water fall" chart indicates the various efficiencies that were calculated and/or assumed for the selected design. As can be seen, the total direct insolation received by the field is $12.93 \mathrm{MW}_{t}$, and the net energy delivered by the system to the bottom of 


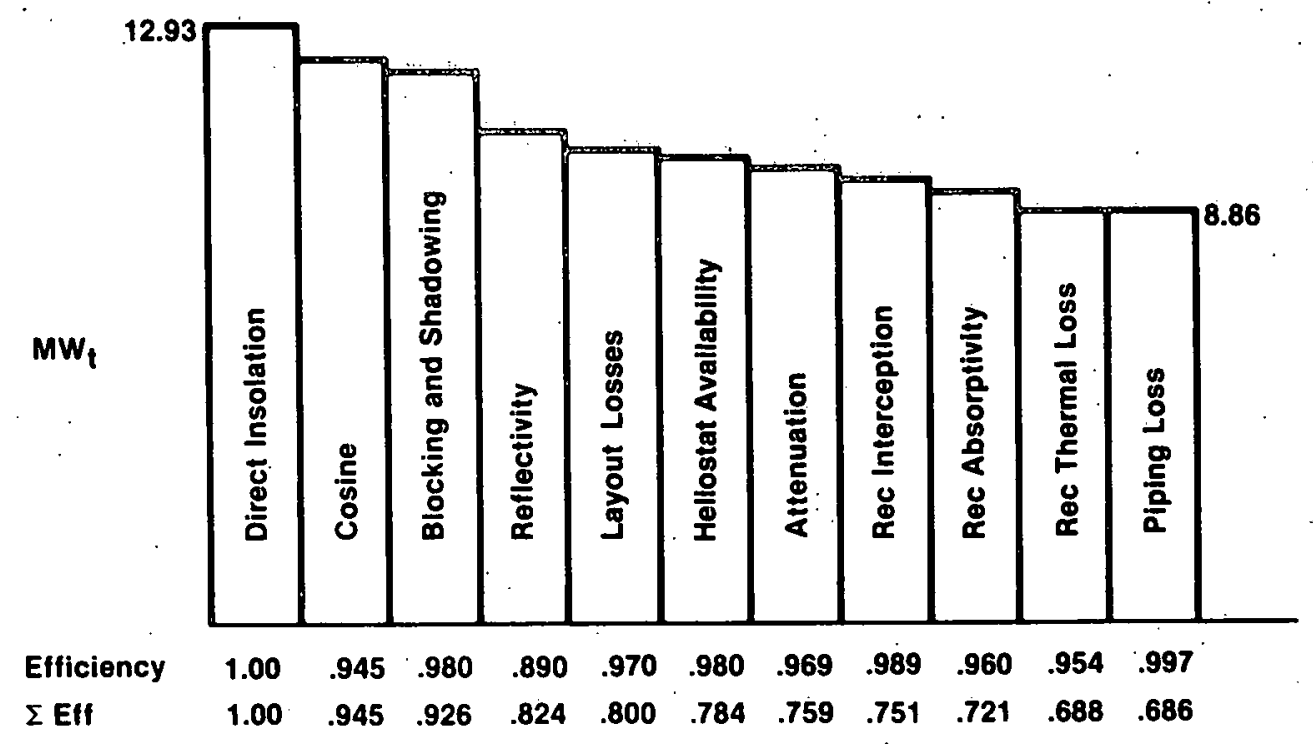

Figure 3.4.1-8. Performance Summary - Design Point (Fall Equinox - Noon)

the tower is $8.86 \mathrm{MW}_{\mathrm{t}}$, which reflects an overall collection efficiency of 0.686. A summary of energy values is given on Table 3.4.1-2.

Table 3.4.1-2. Energy Summary

\begin{tabular}{lcc} 
& Per $\mathrm{m}^{2}$ & Total Field \\
\hline - Peak Insolation & $1000 \mathrm{~W} / \mathrm{m}^{2}$ & $13.76 \mathrm{MW}$ \\
- Design Insolation & $940 \mathrm{~W} / \mathrm{m}^{2}$ & $12.93 \mathrm{MW}$ \\
$\begin{array}{l}\text { Design Power } \\
\text { Delivered to HITEC }\end{array}$ & $646 \mathrm{~W} / \mathrm{m}^{2}$ & $8.89 \mathrm{MW}$ \\
$\begin{array}{l}\text { Average Daily Insolation } \\
\text { 10' - 10 Sun Elevation }\end{array}$ & $4.72 \mathrm{Kwh} / \mathrm{m}^{2}$ & $64.81 \mathrm{MWh}$ \\
$\begin{array}{l}\text { - Average Daily Energy } \\
\text { Delivered to HITEC }\end{array}$ & $2715 \mathrm{Wh} / \mathrm{m}^{2}$ & $37.35 \mathrm{MWh}$ \\
$\begin{array}{l}\text { - Total Annual Energy } \\
\text { Delivered to HITEC }\end{array}$ & $992 \mathrm{KWh} / \mathrm{m}^{2}$ & $13.64 \mathrm{GWh}$ \\
& &
\end{tabular}


The actual heliostat locations resulting from this collector field sizing effort are shown on Figure 3.4.1-9. Each circle on this figure represents a zone of possible heliostat motion plus a $15 \mathrm{~cm}(0.5$ foot) clearance allowance. The packaging factor for this field, defined as glass-to-land ratio, is 0.30 which has been found to be an acceptable value in previous study efforts.
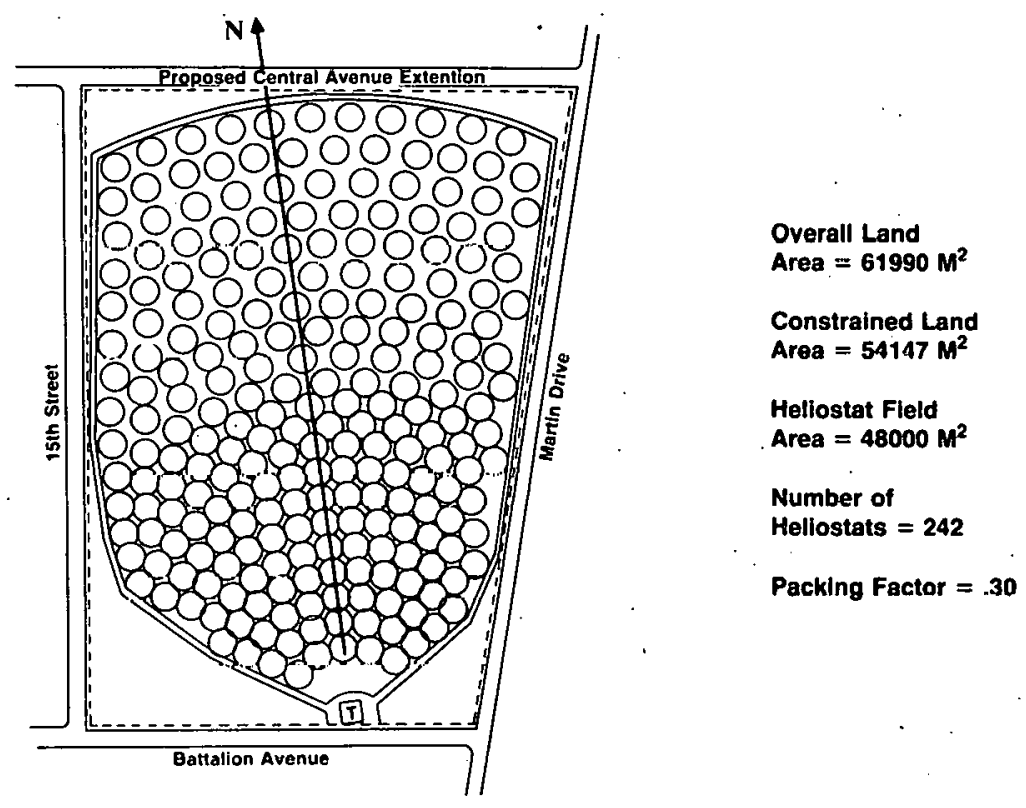

Figure 3.4.1-9. Collector Field Layout

\subsubsection{System Selection and Sizing}

The selection and sizing of the solar cogeneration facility has been accomplished using cost-effective, technologically ready components. The system is designed to convert solar to thermal and electric energy in the most cost-effective manner possible and to displace as large a fraction of natural gas and electric consumption as is feasible. Other features considered desirable in the selected system were a minimum impact on the existing site facilities and a minimum of additional operations personnel.

The monthly load profiles presented in Table 2.7.1-1 show large thermal demands during the winter and large electrical demands during the summer. $A$ load profile such as this does not fit well with the monthly avialable solar energy shown in Figure 2.5.1-4 which peaks during the summer months.' This suggests the use of an absorption chiller during the summer months to convert the 
excess solar energy into cooling in the form of chilled water. The electric air conditioning loads of Table 2.7.1-1 are estimated to consist of 80 percent actual vapor compression energy and 20 percent for cooling tower fans and chilled water pump energy. The vapor compression energy was converted to thermal absorption chilling energy based on a coefficient of performance (COP) of 3.3 for the VC unit and a COP of 1.0 for a two-stage absorption unit. The new thermal energy demands shown in Figure 3.4.2-1 and Table 3.4.2-1 more closely matched the collected solar energy. This was a desirabie effect, but not sufficient to justify selection of the absorption chiller rather than vapor compression. Since the chilling units are used approximately half the year, it is important to select the cycle configuration that would be most efficient. The configuration considered most effective for use with the absorption chiller was a controlled extraction turbine with extraction at $165^{\prime}$ psia and exhaustto the 30 psia steam distribution network. The vapor compression chillers were powered with electricity generated by a controlled extraction at 30 psia for the steam distribution network and exhausting at 2.4 psia. These two systems are illustrated in Figure 3.4.2-2 with the net electrical displacement of the absorption chiller system being twice as large as that of the vapor compression unit. The use of an absorption chiller in the system was, therefore, considered necessary.

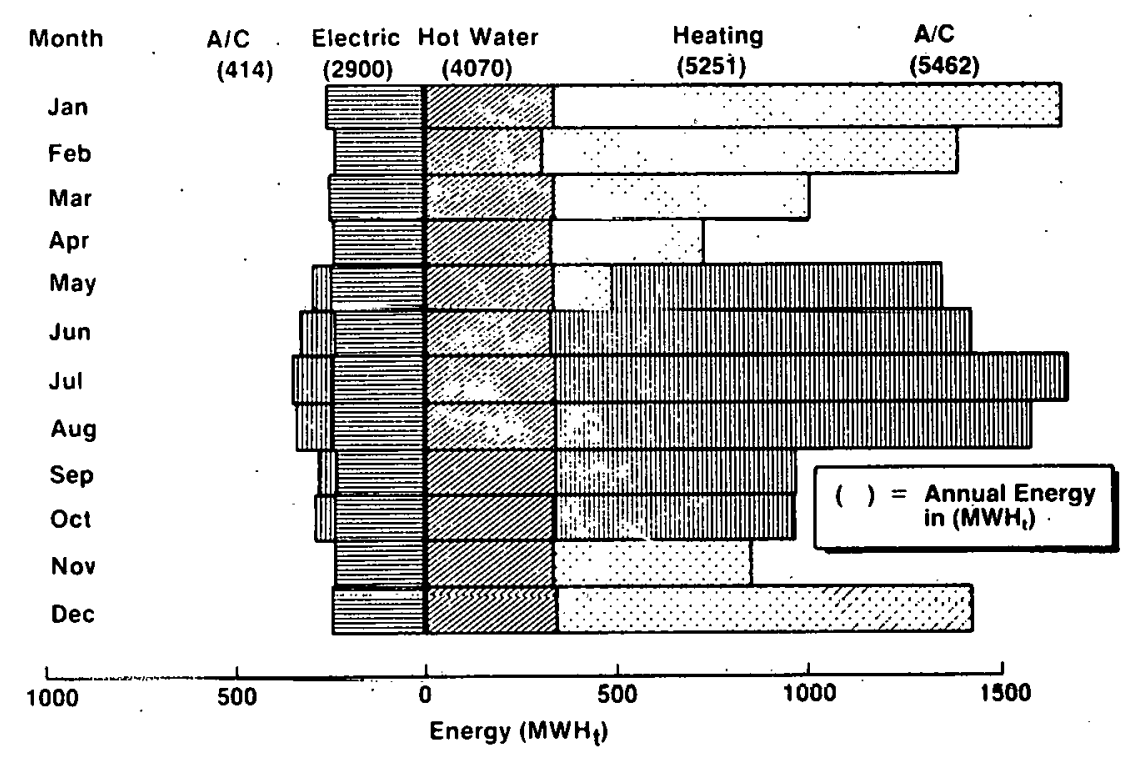

Figure 3.4.2-1. Monthly Energy Demands Absorption Chilling 
Table 3.4.2-1. Fort Hood Estimated Energy Requirements

\begin{tabular}{|c|c|c|c|c|c|c|}
\hline Month & $\begin{array}{l}\text { Room } \\
\text { Heating }\end{array}$ & Hot Water & $\begin{array}{l}\text { Absorption } \\
\text { Chilling }\end{array}$ & $\begin{array}{l}\text { Total Thermal } \\
\text { Load- }\end{array}$ & $\begin{array}{c}\text { Electric } \\
\text { Base } \\
\end{array}$ & $\begin{array}{l}\text { Air Conditioning } \\
\text { Load* }\end{array}$ \\
\hline Jan & $1334 \mathrm{MWh}_{\mathrm{t}}$ & $345 \mathrm{MWh}_{\mathrm{t}}$ & 0 Mllh $t$ & $1679 \mathrm{MWh}_{\mathrm{t}}$ & $253 \mathrm{MWh}_{\mathrm{e}}$ & $0 \mathrm{MWh}_{\mathrm{e}}$ \\
\hline Feb & 1087 & 315 & 0 & 1402 & 228 & 0 \\
\hline Mar & 671 & 345 & 0 & 1016 & 245 & 0 \\
\hline Apr & 403 & 335 & 0 & 738 & 239 & 0 \\
\hline May & 149 & 345. & 443 & 937 & 246 & 33 \\
\hline Jun & 0 & 335 & 1117 & 1452 & 236 & $85^{\circ}$ \\
\hline Jül & 0 & 345 & 1360 & 1705 & 246 & 103 \\
\hline Aug & 0 & 345 & 1267 & 1612 & 246 & 26 \\
\hline Sep & 0 & 335 & 639 & 974 & 235 & 48 \\
\hline Oct & 0 & 345 & 636 & 981 & 245 & 49 \\
\hline Nov & 517 & 335 & 0 & 852 & 238 & 0 \\
\hline Dec & 1090 & 345 & $\underline{0}$ & 1435 & 243 & 0 \\
\hline Total & 5251 & 4070 & 5462 & 14,783 & 2900 & 414 \\
\hline
\end{tabular}

*Electric A.C. consumption not displaced by absorption chiller thermal consumption.

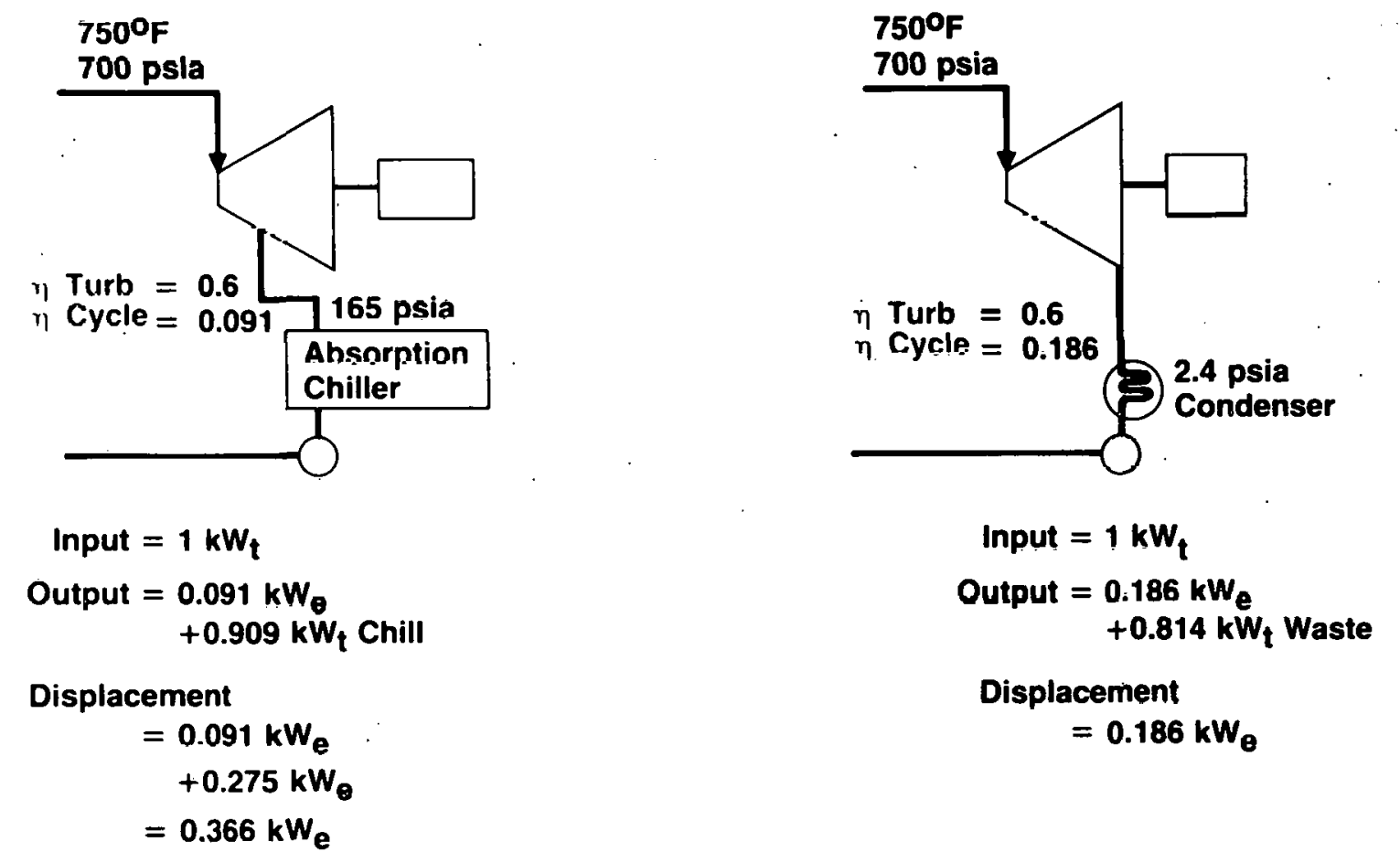

Figure 3.4.2-2. Absorption Chiller Versus Vapor Compression Chiller 
After selection of the absorption chiller, a number of configuration options still remained. One of the first selections addressed was the method of coupling the turbine exhaust energy to the steam distribution network. The two options considered consisted of (1) a direct coupling, sending the steam from the exhaust directly to the network, or (2) an indirect coupling, using a heat exchanger to physically isolate the turbine cycle steam from the distribution network steam.

Utility steam is currently provided by gas fired fire-tube boilers and the returned condensate is directly reused as boiler feedwater. Any contamination of the returned condensate has little effect on the boilers due primarily to two reasons. First, the operating pressure of the boilers, and hence the operating temperature, is low which tends to minimize any tendency for scale formation in the boiler. Second, since the boilers are of a fire-tube. design, any scale formed on the tubes has a tendency to flake off during thermal cycling and falls to the bottom of the tank where it does not interfere with the heat transfer process. As a result, the existing boilers are relatively insensitive to condensate contamination.

The turbine cycle will be using steam at approximately $700 \mathrm{psig}$ and the higher pressure will increase the sensitivity of the system to any contamination. Also, there is a turbine which must be protected from any possibility of solids carryover from the steam generator. This is usually accomplished by limiting the total solids content of the water in the vaporizer. If poor quality feedwater is used, blowdown must be increased to maintain the total solids at a satisfactory level. This decreases the total system efficiency.

In order to maintain good system efficiency, it is therefore necessary to reduce the impurities in the feedwater. This can be accomplished by polishing all returned condensate, or by preventing contamination by isolating the condensate system. The size and type of condensate polisher needed is dependent on the kind and amount of contaminant expected. Isolation of the condensate system requires the use of a heat converter or reboiler. Steam from the main system is used to vaporize the returned condensate and produce the utility steam. The steam from the main system must be at a higher temperature, and therefore a higher pressure, than the utility steam in order for the required 
heat transfer to occur. The economics of the comparison favor the heat converter by a factor of three. The estimated cost of the heat converter is $\$ 33,000$. The budget price from Graver for the condensate polisher is $\$ 100,000$.

The choice of which method to use depends mainly on the expected quality of the returned condensate. The heat converter was selected since the quality of this water at present or in the future is not known and since the heat converter costs less and affords more protection for the turbine and steam generator.

After selection of the absorption chillers and heat converter options, two basic configurations, as shown in Figure 3.4.2-3, were developed. The maximum power/idle case uses hot and cold tanks to store molten salt, pressurized water to store turbine exhaust energy, and two large tanks to store chilled water. The operation of such a system would consist of starting the turbine each morning, producing maximum power for as long as possible during the day, and then turning the turbine off until the next morning. Turbine exhaust energy not needed during the day is converted to pressurized water which can be reconverted to steam at night to supply heating and hot water loads. A typical day's operation is shown in Figure 3.4.2-4.

The second configuration considered as illustrated schematically in Figure 3.4.2-3 is a thermal load-following case. Turbine flow rates are controlled throughout the day so that exhaust energy matched the thermal demand. Pressurized
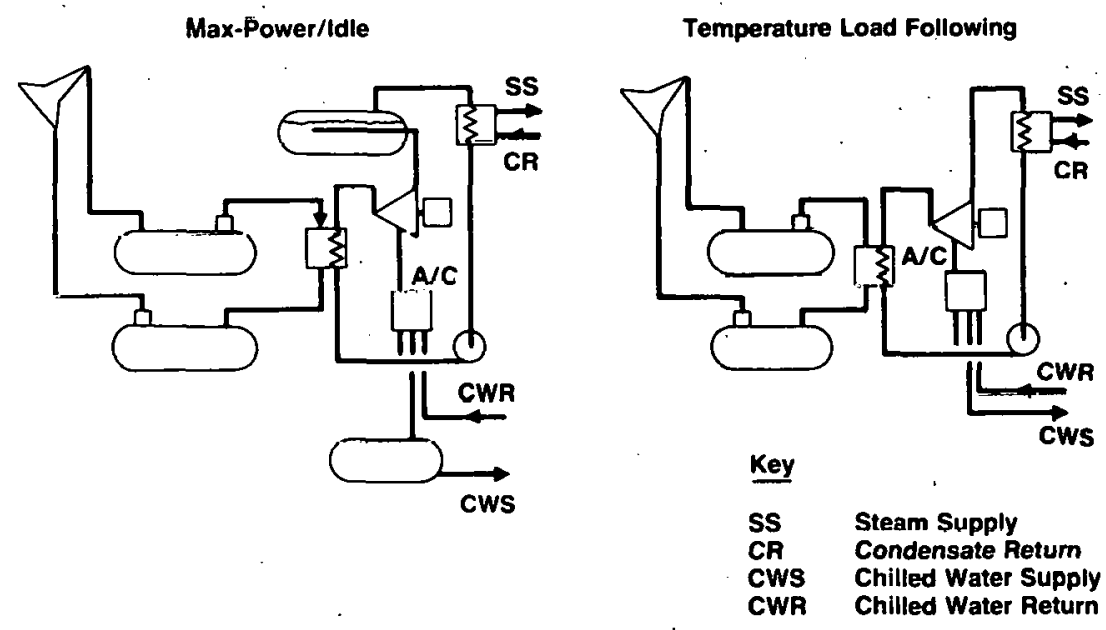

Figure 3.4.2-3. System Configurations 


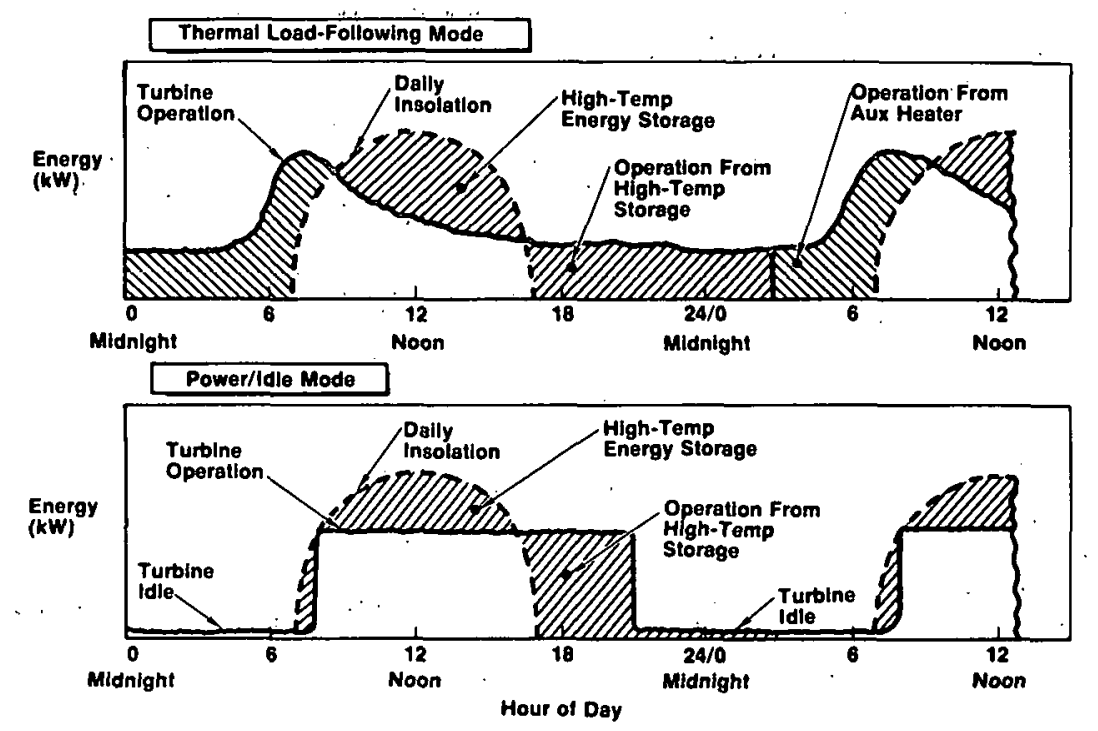

Figure 3.4.2-4. Daily Load Profiles

water and chilled water storage are not needed since the turbine cycle operates 24 hours a day. A major drawback to this system is the wide operating range over which the turbine must operate and the resulting poor conversion efficiency. The selection between these two concepts was accomplished by optimizing each of the configurations and then comparing the net present value of the two.

The optimization and comparison of the two configurations was accomplished using a computer simulation routine capable of modeling an entire year of operation. This program was developed to quickly conduct trade studies relating to the . optimization of collector size, determination of size and type of thermal storage units required, sensitivity of performance to turbine cycle efficiency, and. impact of various operating strategies. The program determines thermal demand loads at hourly intervals based on the complex requirements for heating, liul water, and chilling. Demand for these three components is input for an average day in each month.

The solar collector process is modeled using direct insolation data read from a SOLMET TMY tape for Fort Worth. Field collection efficiency. was obtained from the DELSOL program on an hourly basis for a typical day in each month. The hourly efficiency, direct normal insolation, and heliostat field area are then used to determine the solar energy collected for the hour interval. 
The collected energy is then deposited in high temperature storage. Energy is then extracted from high temperature storage at a controlled rate and used to generate steam for the turbine cycle. This rate is controlled to meet the demand for space heating, hot water and absorption chilling if the load-following configuration is being modeled. The turbine power is also constrained to stay within its operating band of maximum and minimum rating. During periods when high temperature storage is depleted, the gas-fired heater supplies the required energy to the turbine cycle, as illustrated on Figure 3.4.2-4.

The simulation of the maximum power/idle mode of operation is accomplished in a similar manner. Turbine control, however, is more complicated. In this mode it is usually desirable, during periods of solar collection, to run the turbine at its maximum rated power. This will tend to fill low temperature pressurized water storage faster than it can he utilized, When the pressurized water storage reaches full capacity, it will be necessary to "spill" the turbine exhaust energy through the cooling tower. When this condition occurs, it is desirable to reduce the turbine power to minimize spillage and begin to fill high temperature storage. When high temperature storage also reaches capacity, the turbine again goes into full rated power since it is more efficient to make electricity and then spill energy.

The optimization of each configuration was prepared by varying the heliostat area, high temperature storage, low temperature storage and chilled water storage, turbine rating and control strategy. After determining the optimal case for each configuration, the sensitivity of the cost/performance was determined for these parameters. The sensitivity of the net present value of the plant to heliostat field size is shown in Figure 3.4.2-5 for both the loadfollowing and maximum power/idle configuration. These curves illustrate the benefit of increasing field size up to $14,000 \mathrm{~m}^{2}$. Beyond that point, the increased spillage encountered during the spring and fall months redices the cost cffectiveness for the system. The final field layout uses 242 heliostats for $13,700 \mathrm{~m}^{2}$ of mirror area. This same layout was considered close to optimal for both configurations.

A $600 \mathrm{~kW}$ e turbine was selected for use with the load-following case since the turbine selected should be large enough to meet the maximum exhaust steam demand but no larger. The use of a small turbine permits the cycle to operate 


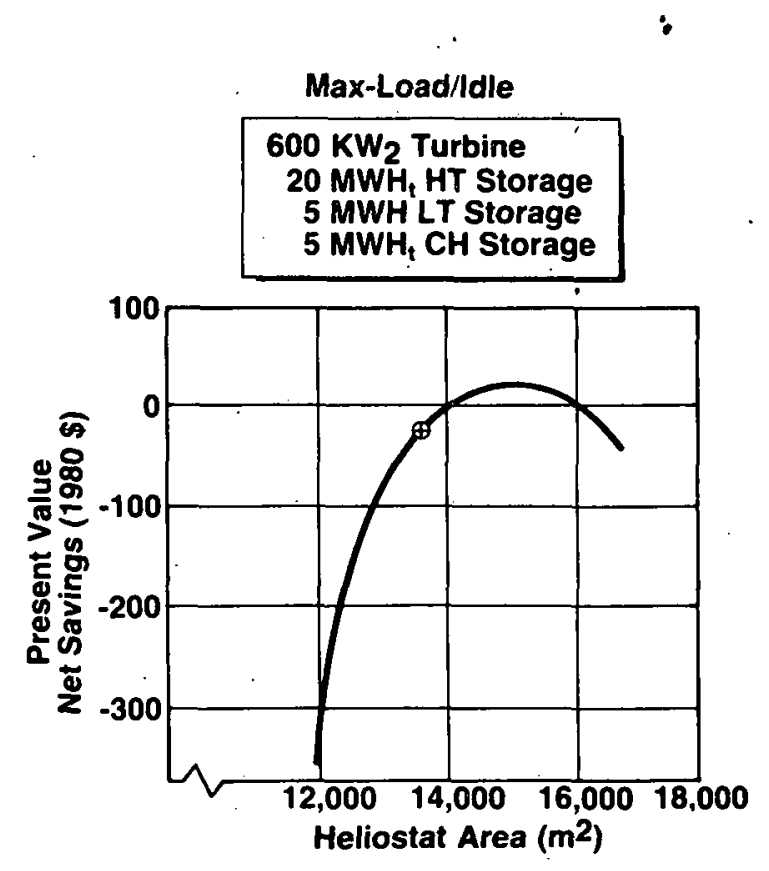

Thermal Load Following

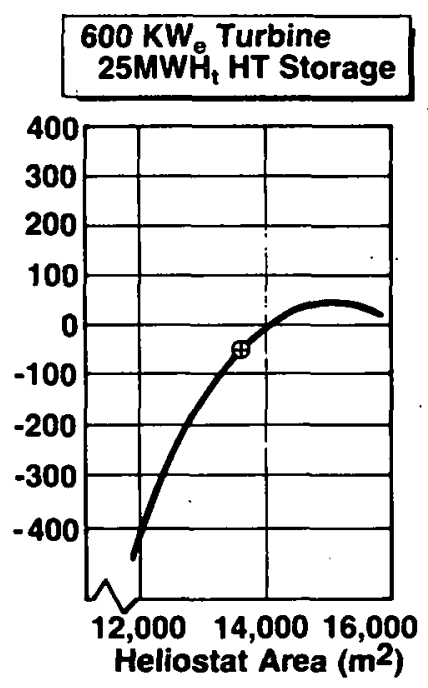

Figure 3.4.2.5. Field Sizing

closer to design conditions and more efficiently most of the time. The loss of performance at off-design turbine powers results insignificantly less electrical power production for the load-following case.

The selection of turbine size for the maximum power/idle case was based on $a^{\text {. }}$ different set of guidelines. The turbine size was not directly dependent on the thermal demands since it was decoupled from these demands by the low temperature and chilled water storage. Instead, a turbine that was capable of oeprating at rates that would minimize the cost of the storage components was desired. Larger turbines were favored for this application due to their higher efficiencies. Results of the computer simulation showed that $600 \mathrm{kWe}$ turbine rating was preferred for this configuration also. Larger turbines did not permit a flexible operation and resulted in large low-temperature storage requirements.

The optimization of storage capacities for the system is discussed in detail in Sections 3.5 .2 and 3.5.3. The results of the simulation study for various storage capacities is shown in Figure 3.4.2-6 for the maximum power/idle case, and Figure 3.4.2-7 for the thermal load-following case. As can be seen from Figure 3.4.2-6, the performance of the max-power/idle case is much more sensitive to high-temperature storage than low-temperature storage. The final design point selected was $20 \mathrm{MWh}_{\mathrm{t}}$ high-temperature capacity and $5 \mathrm{MWh}_{\mathrm{t}}$ low-temperature capacity, resulting in increased gas consumption offset by increased electrical 

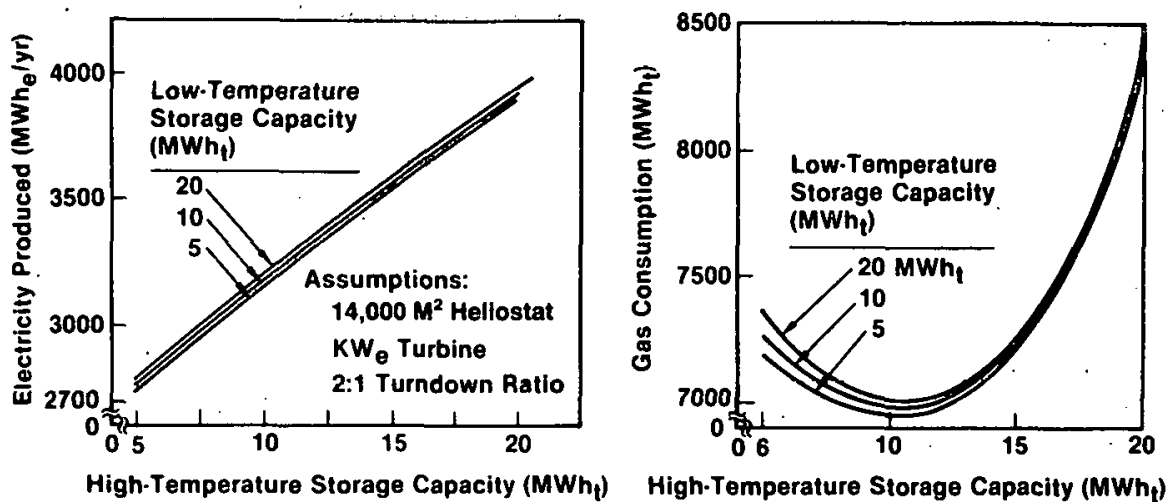

Figure 3.4.2-6. Performance Max-Power/ldle

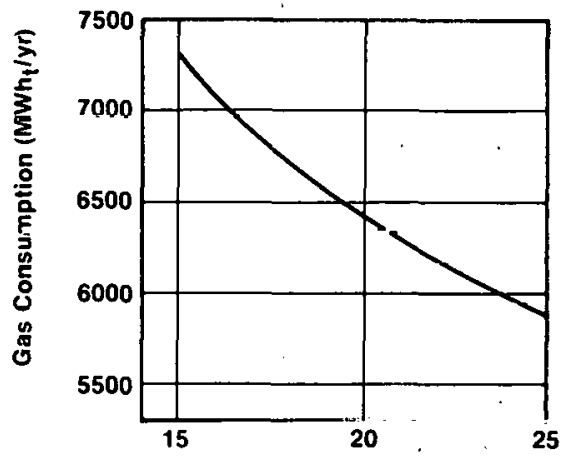

High-Temperature Storage Capacity $\left(M W h_{t}\right)$

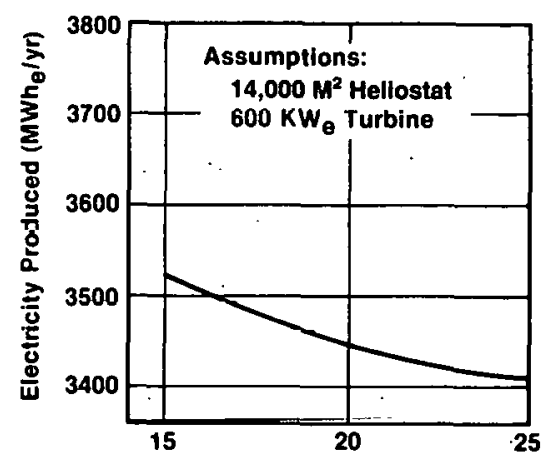

High-Temperature Storage Capacity (MWh $)$

Figure 3.4.2-7. Performance Thermal Load Following

production. The load-following case shows a marked benefit from increased high-temperature storage, resulting in reduced gas consumption with only small reductions in electricity production and, therefore, $25 \mathrm{MWh}_{t}$ capacity was used.

The final selection between the two configurations was based on the economics and potential for further improvements. The performance of the two optimized systems is compared in Table 3.4.2-2. This comparison shows the max-power/idle configuration to possess a significantly larger net present value and it was therefore selected as the preferred system.

This final design is shown schematically in Figure 3.2.4-8. A backpressure turbine supplies steam at 65 psia exhaust pressure to the load, absorption chiller and pressurized water storage unit. Two large tanks at atmospheric pressure are used to store the chilled water. All of the system components are described in the following sections. The final predicted monthly performance of the facility is shown in Figure 3.2.4-9 on a monthly basis. As can 
Table 3.4.2-2. Operating Mode Summary

\begin{tabular}{lcc}
\hline & Max-Power/Idle & Load-Following \\
\hline $\begin{array}{l}\text { Electricity Displaced } \\
(\text { Mwh }\end{array}$ ) & 4367 & 3001 \\
Gas Displayed $\left(\right.$ Mwh $\left._{k}\right)$ & 2395 & 4421 \\
Electricity Credit & $10.5 \mathrm{M}$ & $7.2 \mathrm{M}$ \\
(PV-1986 \$) & $2.3 \mathrm{M}$ & $4.1 \mathrm{M}$ \\
Gas Credit & & \\
$($ PV-1986 \$) & $12.8 \mathrm{M}$ & $11.3 \mathrm{M}$ \\
Total Credit & & \\
(PV-1986 \$) & $-0.1 \mathrm{M}$ & 0.0 \\
Incremental Storage & $12.7 \mathrm{M}$ & $11.3 \mathrm{M}$ \\
Cost (1986 $\$)$ & & \\
Net Present Value & & \\
\hline
\end{tabular}

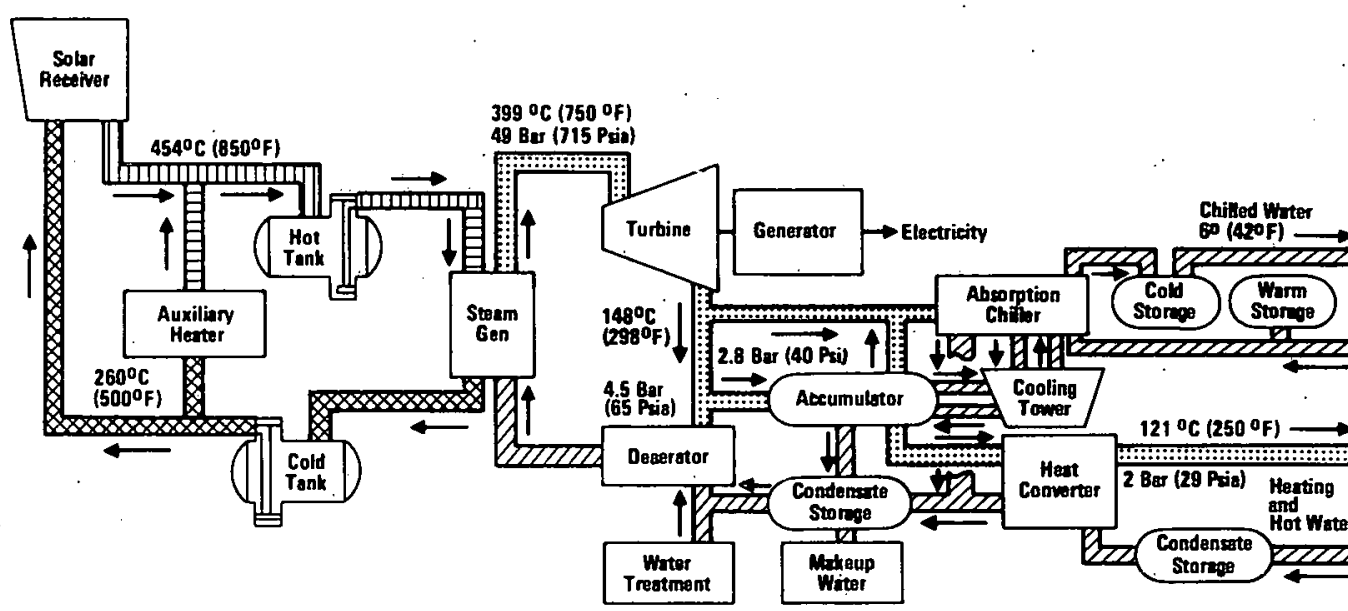

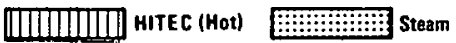

HITEC (Cool) QZTZZZW Water

Figure 3.2.4-8. System Flow Schematic

be seen, mostof the electrical demand is displaced during most of the months while an excess of thermal exhaust energy is present during the fall and winter months. Althorugh some of this spillage is unavoidable, a portion of it can be eliminted with consequent gas savings by future modifications to the operational strategy. Estimates of this potential savings range from $1000 \mathrm{mwh}_{k}$ to 1500 mwh $_{k}$ gas consumption per year resulting in an additional $1.0-1.5$ million dollar net present value. 


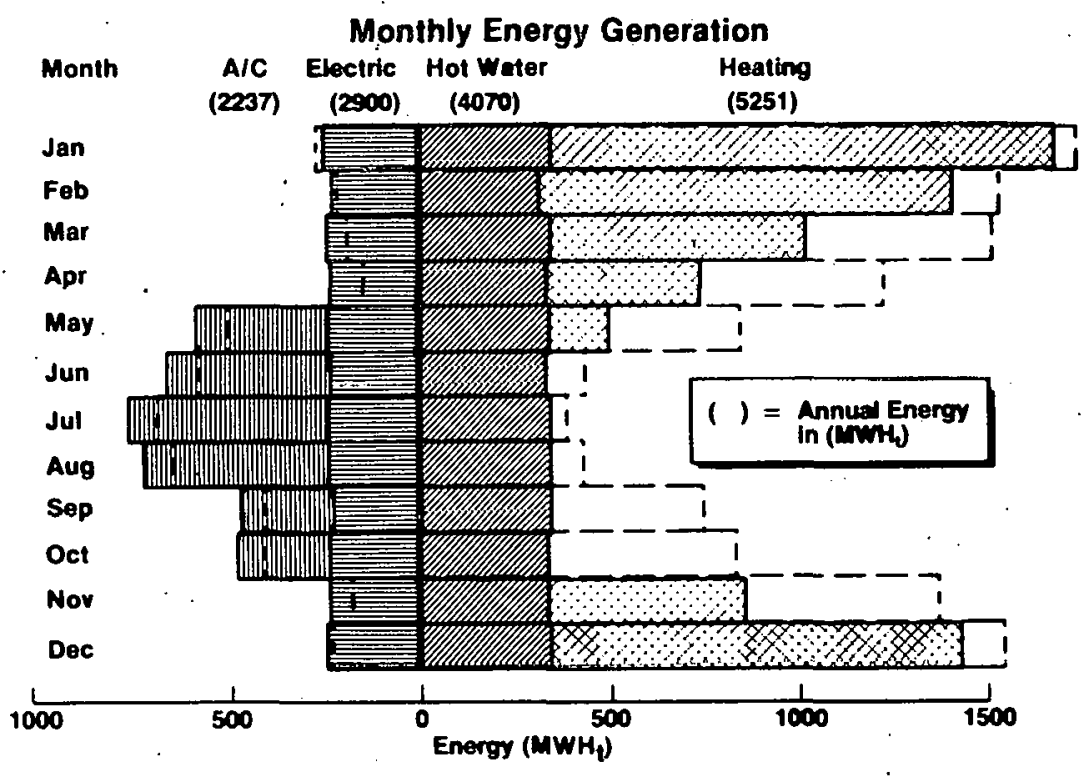

Figure 3.2.4-9. Monthly Energy Demands - Present

\subsection{Trade Studies}

In support of the evaluation of candidates system configuration, several trade studies were conducted on major subsystem components. These trade studies and key issues include the following:

- Turbine/generator equipment (type, rating, efficiency, availability, cost)

- High-temperature storage (therimal capacily, heat losses)

- Low-temperature storage (type, capacity, cost)

- Air conditioner (type, capacity, availability, cost.)

- Steam generator (typc, cupucity, avallability, cost)

- Fossil fueled heater (type, capacity, availability, cost)

- Plant control automation (magnitude, safety, costs, manloading)

- Solar equipment location (interfaces, performance, access, facility mods.)

Each of these trade studies is reviewed in the following subsections.

\subsubsection{Turbine/Generator Equipment}

The system level trade study indicated that a $600 \mathrm{~kW}$ size turbine/generator $(T / G)$ operating with inlet conditions of 49 bar $(715 \mathrm{psia}), 399^{\circ} \mathrm{C}\left(750^{\circ} \mathrm{F}\right)$ steam, and with a back pressure of 4.5 bar ( 65 psia) would be most suitable for the Fort Hood application. 
A set of preliminary specifications was written and made available to a number of T/G manufacturers. The preliminary specifications are shown in Table 3.5.1-1. Since the turbine back pressure is established by the requirements of the absorption cooler or the hot water generation system, the preliminary specifications required turbine operation for two different back pressure modes (150 psig and $50 \mathrm{psig}$ ). The turbine survey was conducted with suppliers of both radial and axial turbine designs. The resulting designs included singlestage and multistage equipment. The $T / G$ selection was limited to either standard off-the-shelf equipment or to standard designs that did not require further development.

Table 3.5.1-1. Turbine-Generator Requirements Fort Hood Solar Cogeneration Plant

Type

Rating, max.

Rating, min.

Turbine type

Steam inlet temperature

Steam inlet pressure

Steam back pressure

Mode 1

Mode 2

Speed

Generator rating

Electrical

Generator type

Generator speed

Control function required

1. Speed governor

2. Automatic unattended operation

3. Automatic start/stop, synchronize

4. Operation safety trips Desired efficiency - rated conditions
Rankine

$600 \mathrm{~kW}$

$100 \mathrm{kH}$

TBD

$750^{\circ} \mathrm{F}$

700 psig

150 psig

50 psig

TBD

$600 \mathrm{kH}, 750 \mathrm{KVA}$

$480 / 277 V, 3 \phi, 60 N$

TBD

TBD

TBD

TBD

TBD

TBD

$60 \%$ minimum 
The survey showed that no supplier had a standard design small enough to operate at the $600 \mathrm{~kW}$ level while operating with full admission porting. Thus, all designs were restricted to partial admission configurations. The turbine suppliers considered for this application included the following:

1. Trane Company, Murray Steam Turbine Div., Lacrosse, Wis.

2. Elliott Company, Jeannette, Pa.

3. McGraw-Edison Company, Turbodyne Corp., Wellsville, N. Y.

4. Terry Steam Turbine Company, Windsor, Conn.

5. Mechanical Technology, Inc., Latham, N. Y.

6. Rotoflow Corporation, Los Angeles, Ca.

7. Energy Technölogy, Inc., Cleveland, Ohio

In general, the performance levels of all machines were found to be similar and in good agreement with the theoretical curves published for axial and radial full admission and axial partial admission machines. The flow conditions for the turbines dictated turbine speeds on the order of $5000 \mathrm{rpm}$ or higher.

The standard generator for 480V, 3 phase, 60 cycle service is a four-pole machine which turns at $1800 \mathrm{rpm}$. Hence, all $\mathrm{T} / \mathrm{G}$ packages considered included a stepdown gear box between the turbine and the generator.

The preliminary specifications required two different levels of exhaust back pressure, depending on which absorption cooler was selected.. The final cooler selected eliminated the higher exhaust back pressure condition (150 psig) and permitted all turbine operation at the lower value (50 psig). The combination of a partial admission turbine running with a pressurized exhause resulted in a lowering of the delivered expansion efficiency from the levels obtainable with full admission turbines operating at subatmospheric back pressures; however, this lower efficiency is due to thermodynamic considerations and not to the mechanical design of the turbines.

The T/G selected for this conceptual design application is the Trane model TMG using a single stage Curtiss turbine and a standard Marathon (or Ideal) generator. A sketch and the estimated performance of this unit are shown in Figures 3.5.1-1 and 3.5.1-2, respectively. The performance predictions are based on a $30 \mathrm{HP}$ loss in the gear box and with a generator efficiency of $95 \%$. Hence, the turbine delivers 880 B.H.P. to the shaft when the net generator output is $600 \mathrm{~kW}_{\mathrm{e}}$. 


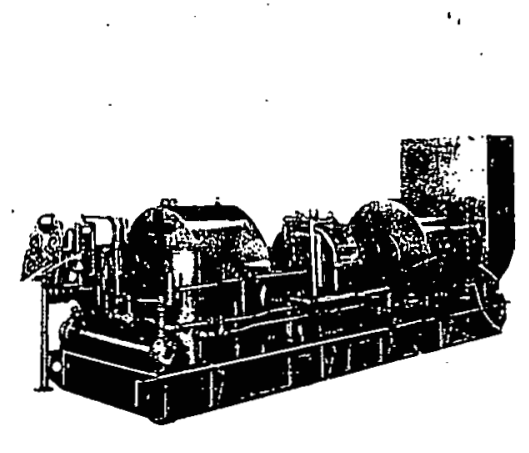

MAKE: TRANE

MODEL: TMD

RATING: $880 \mathrm{HP}$ a $6000 \mathrm{RPM}$

TYPE: PARTIAL ADAISSION, CURTISS, ONE HAND VALVE

GEMERATOR:: MARATHON

MODEL: - MAGNA ONE

RATING: $\quad 600 \mathrm{KW}$ a $1800 \mathrm{RPM}$

TYPE: $\quad 489 \mathrm{~V}, 3 \%, 60$ 2

CONTROL T/E WOODWARD GOVERNOR WITH:

- auto start

- SYHCHRCHIZER !!/VOLTAGE MATCHING

Figure 3.5.1-1. Turbine Generator Selection

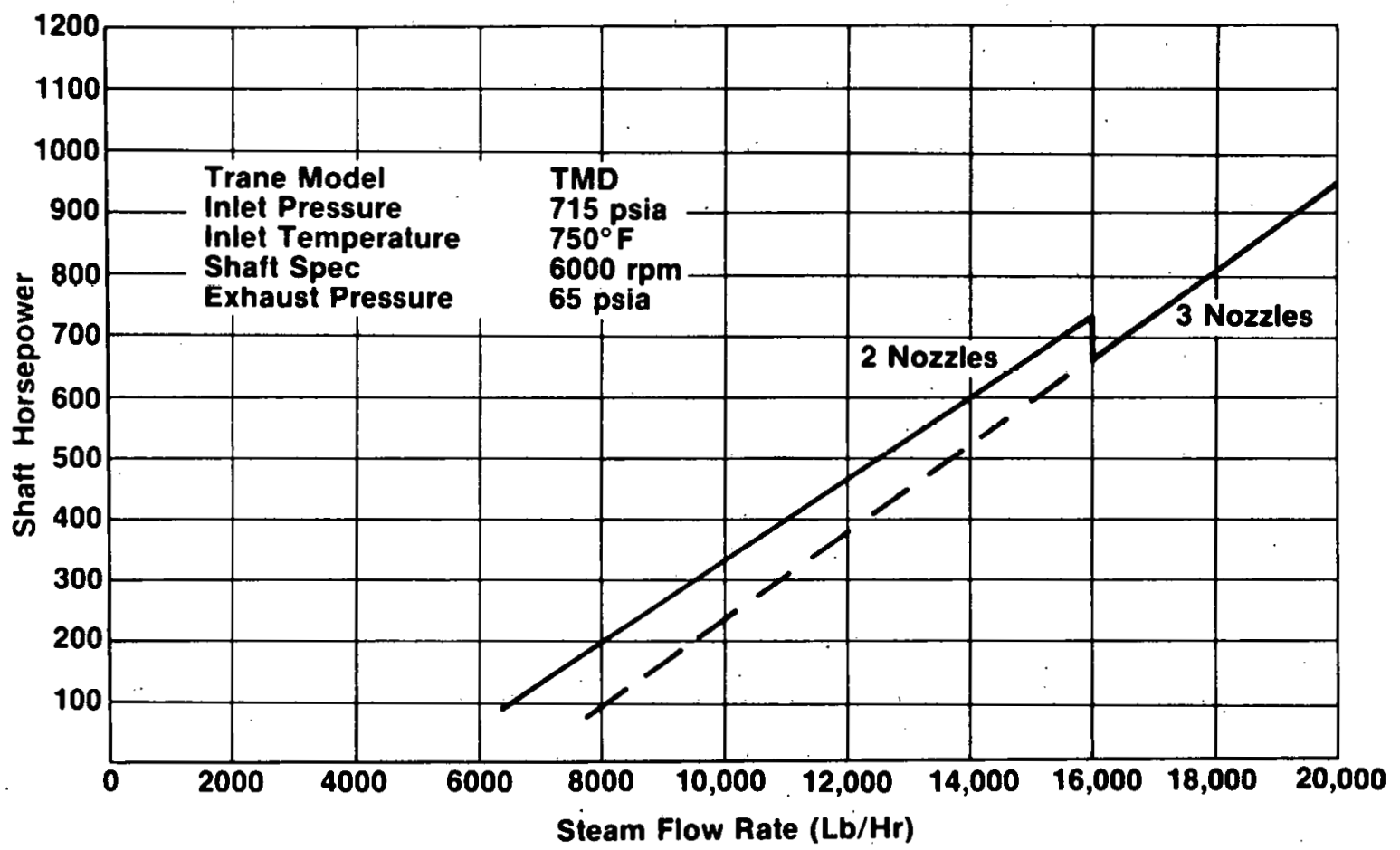

Figuro 3.6.1 2. Estimatod Turbino Porformanioo

The original specification required a turndown ratio of 10 to $1(600 \mathrm{kWe}$ $60 \mathrm{~kW}$ ) which resulted in very low performance efficiency (of all turbines) at the lower power setting. The final system operating characteristics revised the turndown ratio to 2 to $1(600 \mathrm{kWe}$ to $300 \mathrm{kWe})$. To improve the turbine performance at the lower load setting, one segment of the turbine nozzles can be closed at low load conditions. This reduction in turbine nozzle area is usually referred to as operation with one hand-valve closed. The preliminary design of the T/G for Fort Hood indicates that oniy 3 nozzles. (out of a maximum of 18) will be required to meet the present requirements. Therefore, the turbine will be configured such that it will run with 
all three nozzles open for full power $\left(600 \mathrm{~kW}_{e}\right)$ and with two nozzles for the reduced power setting $\left(300 \mathrm{~kW}_{\mathrm{e}}\right)$. The delivered expansion efficiency at the lower power will be degraded approximately $10 \%$.

The selected Trane T/G package is a standard, off-the-shelf unit which has been configured by Trane for cogeneration applications and is being used for this purpose on several non-solar cogeneration applications. The unit can be supplied with all of the accessories needed to operate in a cogeneration mode, with automatic start sequencing and automatic synchronizing capability. The approximated cost of the unit will be in the $\$ 110,000$ to $\$ 130,000$ range, depending on the final accessory selections. The single stage Curtiss turbine designs are becoming very popular for cogeneration applications. These units are inexpensive and since the heat of the turbine exhaust is recovered and used for other purposes, the absolute value of expansion efficiency has little effect on the overall system performance.

\subsubsection{High Temperature Storage}

Solar energy will be collected at varying rates which can exceed turbine requirements to meet the complex thermal demand. Thermal energy storage is provided to efficiently utilize as much collected energy as possible and to act as a buffer to eliminate the effects of solar transients on the turbine. Based on low cost and risk, the two-tank storage concept utilizing the sensible heat of molten salt (HITEC) was fixed as the baseline design. As shown in Figure 3.5.2-1, the subsystem basically requires one steel tank to contain the inventory of molten salt at $454^{\circ} \mathrm{C}\left(350^{\circ} \mathrm{F}\right)$ and another at $260^{\circ} \mathrm{C}$ $\left(5 \cap n^{\circ} \mathrm{F}\right)$.

The object of this trade study was to determine the optimum thermal capacity considering annual insolation and thermal demands at the complex for various turbine operating conditions and system configurations. As shown in Figure 3.5.2-2, two operating modes were examined. In the load following case, the turbine runs continuously to match the thermal demands of the complex. At night, energy is supplied from thermal storage and from the fossil heater when storage is depleted. In the second case, the turbine operates more efficiently at or near maximum power. Energy from the turbine exhaust in excess of the demand is delivered to low temperature storage for use follnwing 


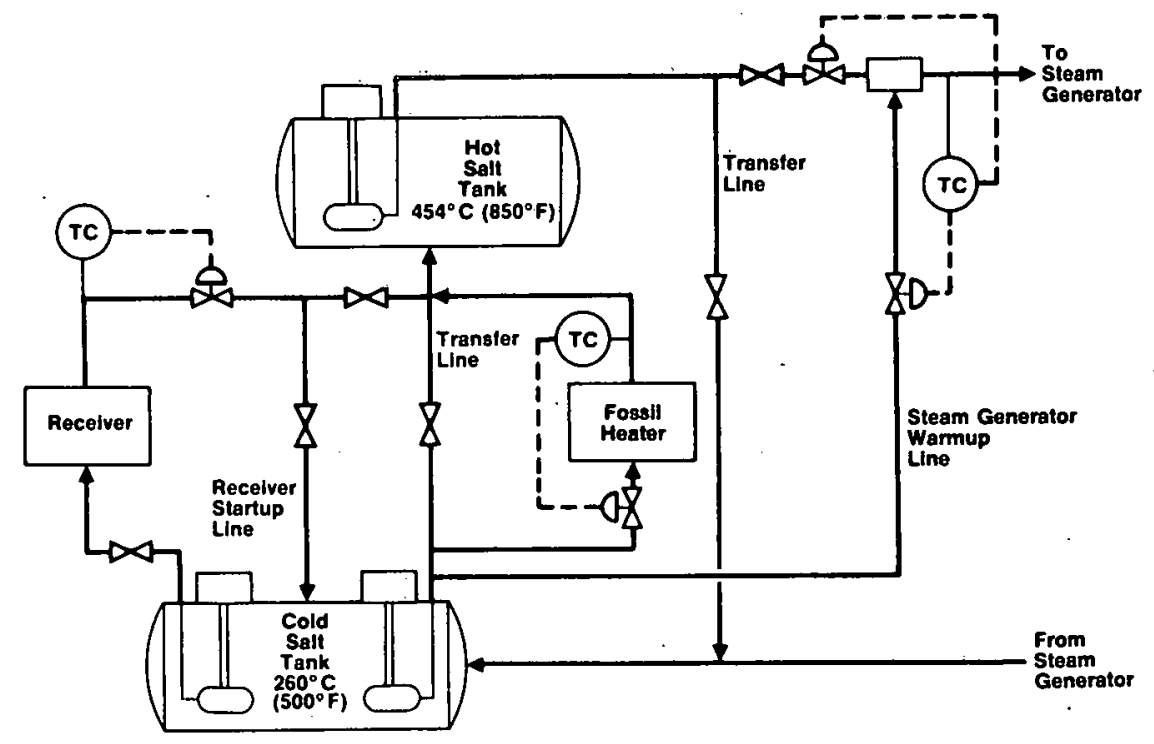

Figure 3.5.2-1. High-Temperature Storage Concept

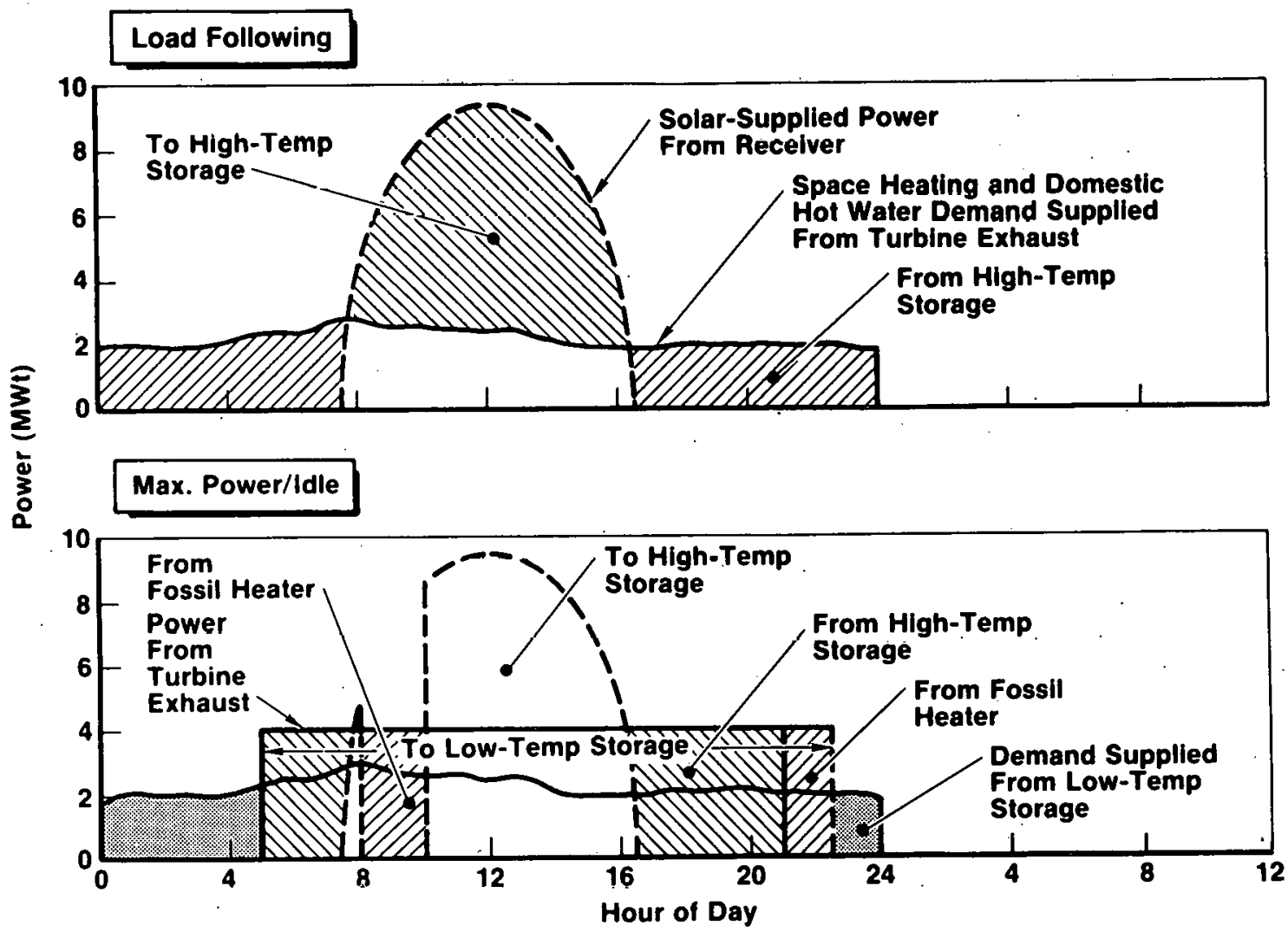

Flgure 3.5.2-2. Operating Modes 
turbine shutdown. The fossil heater is used to conitinue turbine operation if high temperature storage is depleted and low temperature storage is not adequately charged.

As thermal storage capacity is increased, less makeup energy is required from the fossil heater and less gas is consumed. An optimum storage capacity will then exist where the present value capital cost of increasing storage does not justify the present worth of additional gas saved or electricity produced over the system life. Capital equipment costs included installed tanks, insulation, and storage media, while the present worth of gas and electricity was determined to be $\$ 750 / \mathrm{MWH}_{t}$ and $\$ 2400 / \mathrm{MWH}_{t}$, respectively.

The present value savings resulting from increasing high temperature storage capacity are shown in Figure 3.5.2-3 for a load following $600 \mathrm{KW}_{\mathrm{e}}$ turbine. The optimum capacity increases from 20 to $29 \mathrm{MWH}$ for collector areas varying from 12,000 to $16,000 \mathrm{~m}^{2}$. For the same turbine operating at maximum power for limited periods each day, the optimum storage capacity is $20 \mathrm{MWH}_{t}$ with a $14,000 \mathrm{~m}^{2}$ collector field. The optimum capacity is not significantly affected by the size of low temperature storage capacity in the size range considered.

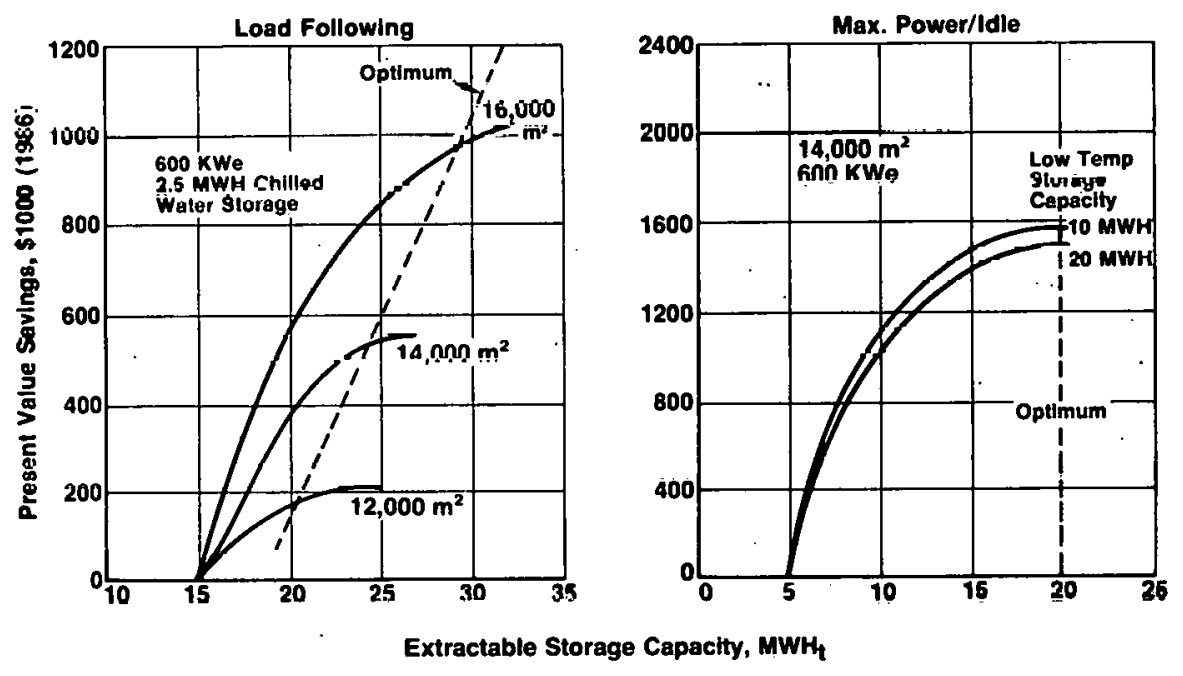

Figure 3.5.2-3. High Temperature Storage Optimization 


\subsubsection{Low Temperature Storage}

Space Heating and Domestic Hot Water

If the turbine does not follow the thermal demand from the complex, low temperature thermal energy storage is required to meet this demand when the turbine is not operating. As shown in Figure 3.5.3-1, this can be accomplished in two ways. In the first concept, excess steam from the turbine exhaust which is not required to meet the demand is diverted to a steam accumulator and stored as pressurized hot water at 65 psia. After the turbine is shut down, steam is extracted at 40 psia and supplied to a heat converter which provides steam to the existing distribution system at 30 psia. Condensate from the converter is stored in a separate tank until it can be pumped to the deaerator during turbine operation. In the second concept, all turbine exhaust steam flows through the heat converter. The low pressure steam generated and distributed to the various buildings exceeds that required for space heating and domestic hot water. The excess hot water produced in each building must, therefore, be stored in separate tanks. Because of the inefficient air handling equipment. at the complex, the difference between the supply water temperature and return temperature is less than $\left(6^{\circ} \mathrm{C}\right) 10 \mathrm{~F}^{\circ}$. This not only implies large storage volumes, but probably precludes the use of a single thermocline tank (at each location). Unless a separate heat exchanger is installed, the capacity of each DHW generator would have to be increased as well. For $5 \mathrm{MWh}_{t}$ of low temperature storage (assuming a thermocline tank could be used), this concept is more

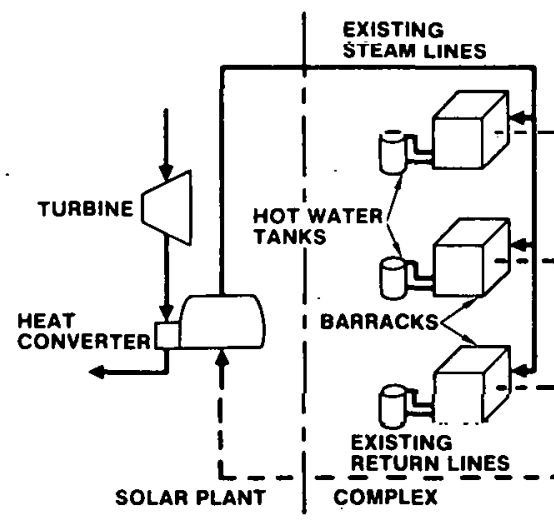

DISTRIBUTED HOT WATER STORAGE

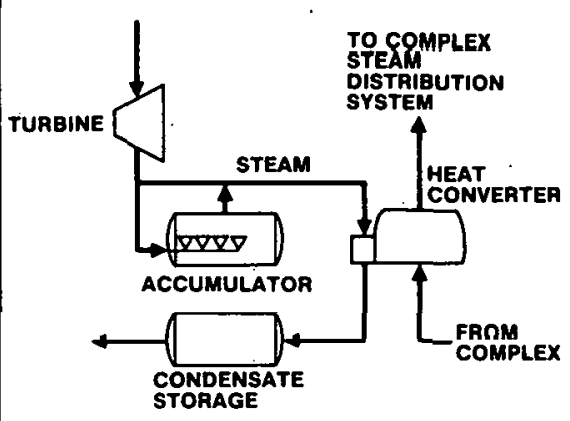

PRESSURIZED WATER STORAGE - SELECTED CONCEPT - NO FACILITY MODIFICATIONS - LOWER COST

Figure 3.5.3-1. Low Temperature Storage Concepts 
than twice as expensive as the first without considering the additional piping, controls, pumps, and installation costs. The steam accumulator was, therefore, chosen as the desired concept on the basis of lower cost and no facility modifications.

With increasing low temperature thermal storage capacity, the optimum size was determined by comparing increasing capital costs of the accumulator, condensate receiver, and insulation with the associated savings in gas consumption and electricity production. Based on demand profiles and turbine operating durations during winter months $5 \mathrm{MWh}$ of low temperature storage was estimated. to be the minimum capacity required. With $20 \mathrm{MWh}$ of high temperature storage, Figure 3.5.3-2 shows that increased capacities above this quantity are not economically justified. This conclusion is based on using a $600 \mathrm{~kW}_{\mathrm{e}}$ turbine with a $14,000 \mathrm{~m}^{2}$ collector field.

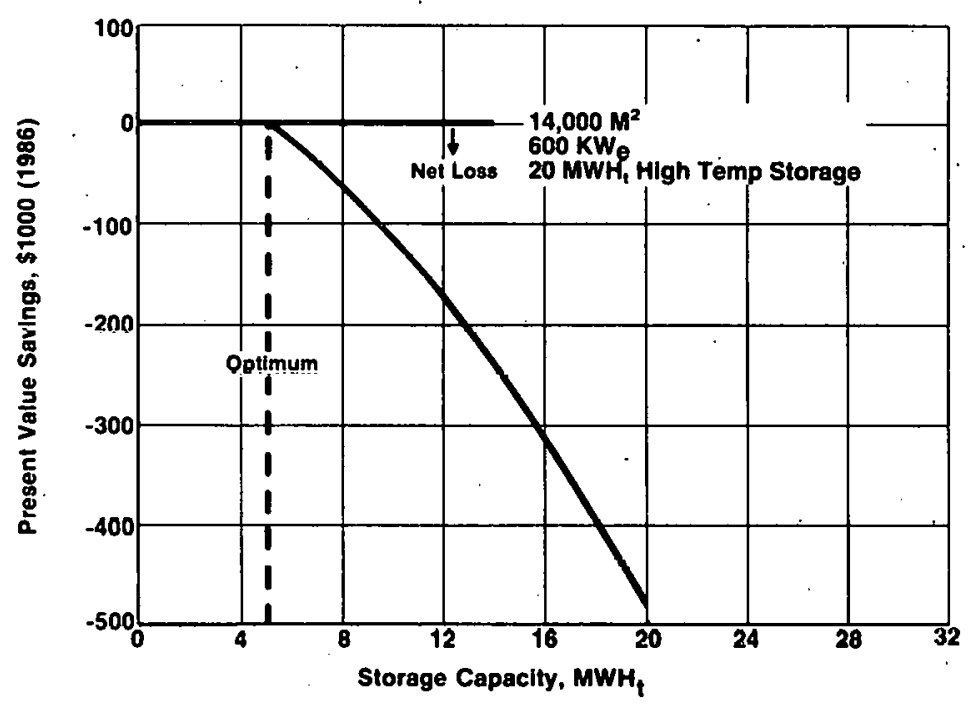

Figure 3.5.3-2. Low Temperature Storage Optimization

\section{Chilled Water Storage}

The absorption chiller will be operated with a constant output during the day. The excess chilled water produced will be stored in a tank at $\left(6^{\circ} \mathrm{C}\right) 42^{\circ} \mathrm{F}$ for use when the chiller is turned off. Return water from the complex is stored in a separate tank as shown in Figure 3.5.3-3. Present value savings associated with increasing storage capacity were examined for a load following. turbine and for the maximum power/idle turbine mode. The results are presented in Figure 3.5.3-4. For the on/off mode, which was selected as the base- 


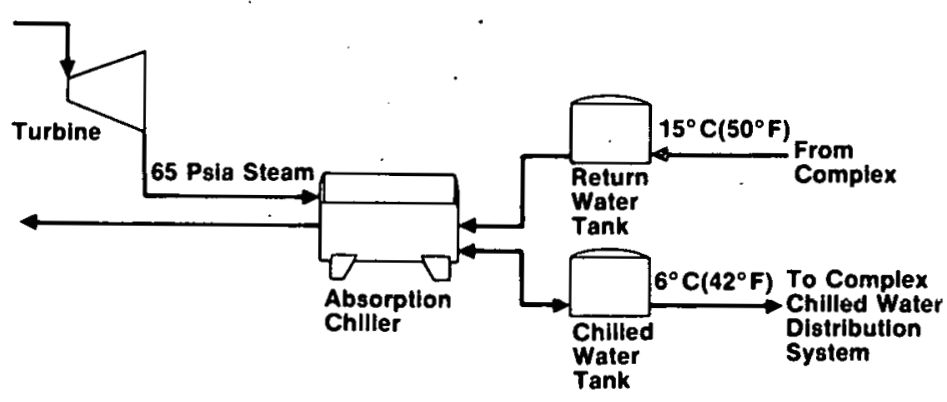

Figure 3.5.3-3. Chilled Water Storage Concept

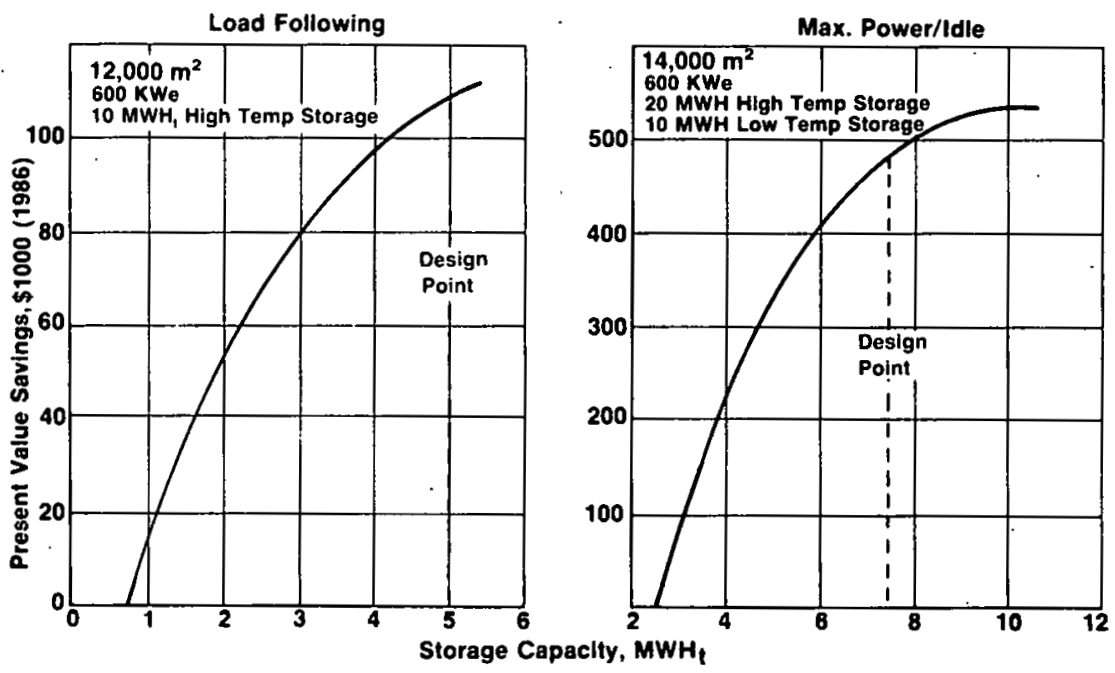

Figure 3.5.3-4. Chilled Water Storage Optimziation

line, a chilled water storage capacity of $7.5 \mathrm{MWt}_{h}$ was determined to be economically desirable. This is based on a $14,000 \mathrm{~m}^{2}$ field and $20 \mathrm{MWh}_{\mathrm{t}}$ of high temperature storage.

\subsubsection{Air Conditioning Unit.}

The air conditioning unit required for Complex 87000 will need an output of 600 tons and should operate with a steam pressure which is no higher than the steam pressure required for the hot water system. The original proposal covered the use of a 600 ton, two-stage absorption type air conditioner. Since only one company, the Trane Company, supplies units in this size range, no formal specification was prepared. Instead of a formal specification preparation, the design data for absorption coolers in the $600-1000$ ton range were requested from Trane. Since Trane makes both single and two-stage absorption coolers, data were obtained for both types of units. The two-stage 
units are available for operation with steam at 144 psig, at 123 psig, or with hot. water. The single stage units can be operated with low pressure steam (<15 psig) or with hot water. The design conditions for Fort Hood include a chilled water temperature of $42^{\circ} \mathrm{F}$, a coolant water temperature of $85^{\circ} \mathrm{F}$, and a coolant water supply adequate to maintain the coolant outlet temperature at $95^{\circ} \mathrm{F}$.

To meet the cooling requirements of Complex 87000 , five different Trane units were considered. These were as follows:

\section{Single stage:}

Model $A B S C=06 C$

665 tons

$A B S C-08 C$

852 tons

Two-stage:

Model ABTD-06A

600 tons

ABTD-08C

800 tons

ABTD-10C

1000 tons

The output level of all of these machines are controlled by the hot fluid mass flow. The mass flow is normally controlled by changes in supply pressure of the driving steam. The steam pressure requirements for the five units are shown on Figure 3.5.4-1. The three versions of two-stage machines are shown for the lower steam pressure configuration (123 psig), because the low pressure version was of more interest than the higher, pressure two-stage untts.

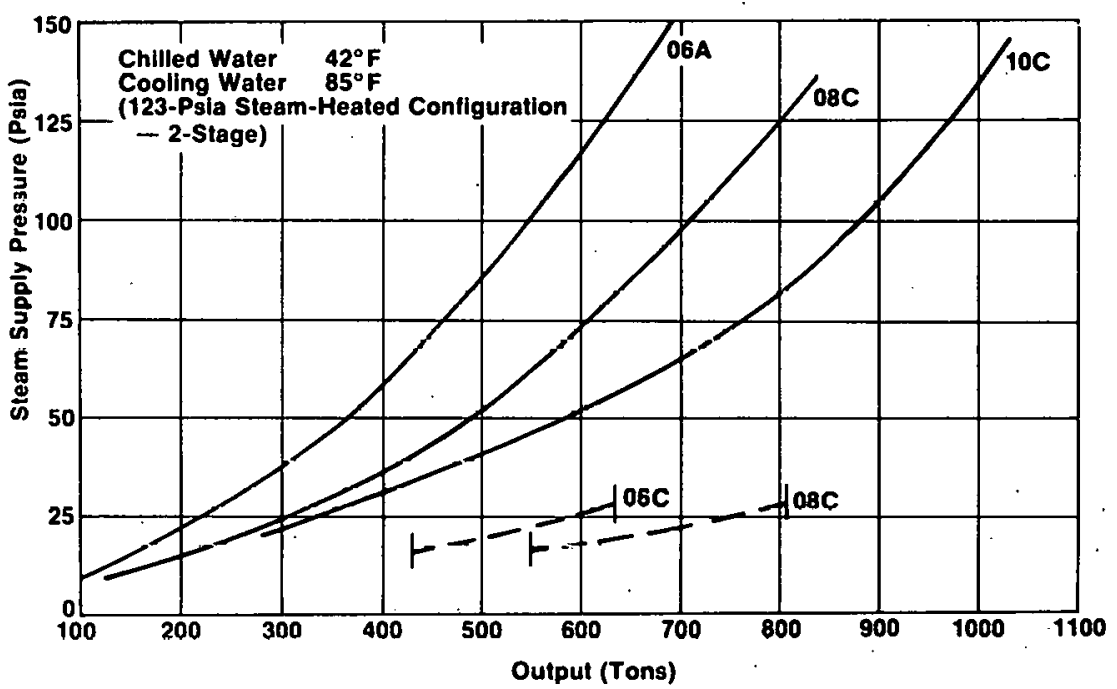

Figure 3.5.4-1. Candidate Absorption Cooler Trane Data 
As can be noted, the nominal rating of $600 \mathrm{~T}$ can be obtained with all five machines, but with different supply pressures for each. The required mass flow of drive steam for the various units is shown on Figure 3.5.4-2. The rates for the single stage and for the two-stage units vary with cooling capacity, but remain constant for the various models of a given type. Since the required capacity can be obtained with each of these machines, but at different supply pressures, and since the turbine performance varies with turbine back pressure (cooler supply pressure), a cost/performance trade was required to optimize the cooler selection. The performance and cost data for the coolers were input to the system level trade study, in which cooler requirements were definitized. The requirements generated with this method indicate that a $600 \mathrm{~T}$ rating was adequate and that the supply pressure should be 65 psig or less.

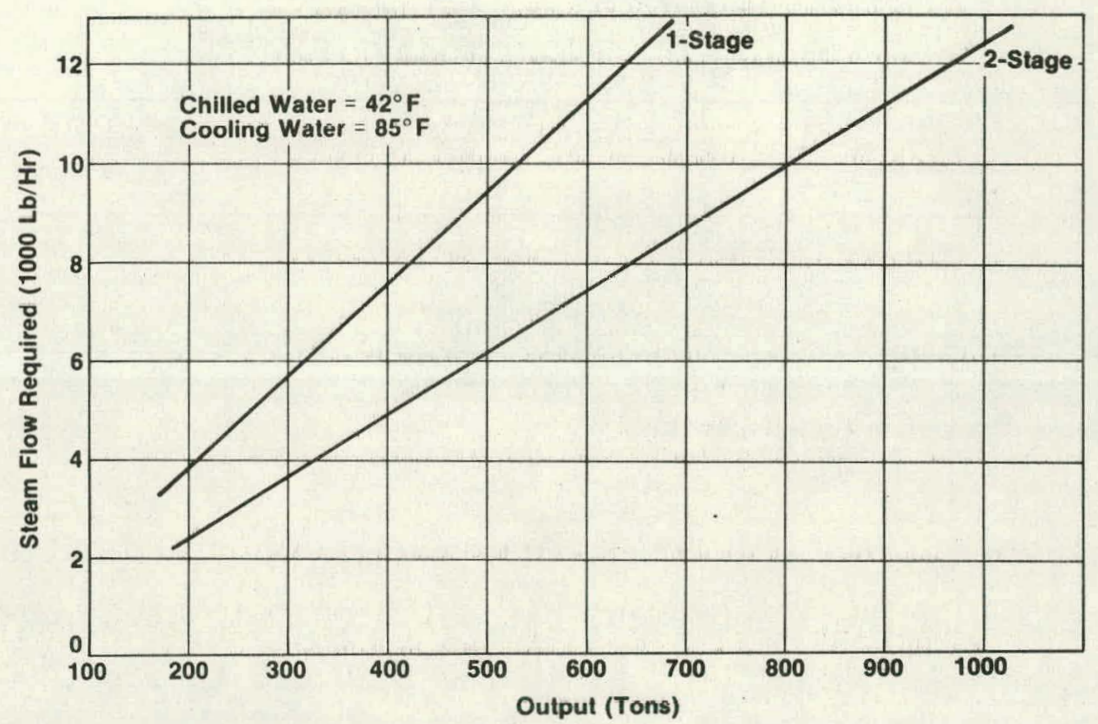

Figure 3.5.4-2. Two-Stage Absorption Cooler Trane Data

The overall system trade study has indicated that a derated two-stage absorption cooler will be the most satisfactory selection for this application. The tentative selection is, therefore, the Trane Model ABTD-08C. This unit can supply the 600 tons of cooling required at less than 75 psia $(60 \mathrm{psig})$. The turndown ratio on this model is excellent, as was shown on Figure 3.5.4-7. The selected model is shown on Figure 3.5.4-3 with dimensions indicated. A flow schematic of this unit is shown on Figure 3.5.4-4. 


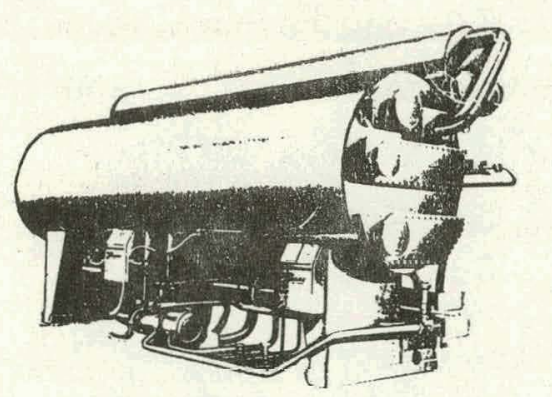

$$
\begin{array}{ll}
\text { MAKE: } & \text { TRANE } \\
\text { MODEL: } & \text { ABTD-08C } \\
\text { TYPE: } & \text { TWO STAGF } \\
\text { SIZE: } & \text { LENGTH } 23^{\prime} 1^{\prime \prime} \\
& \text { HEIGHT } 13^{\prime} 6^{\prime \prime} \\
& \text { WIDTH } 10^{\prime} 5^{\prime \prime} .
\end{array}
$$

Figure 3.5.4-3. Absorption Cooler Selection

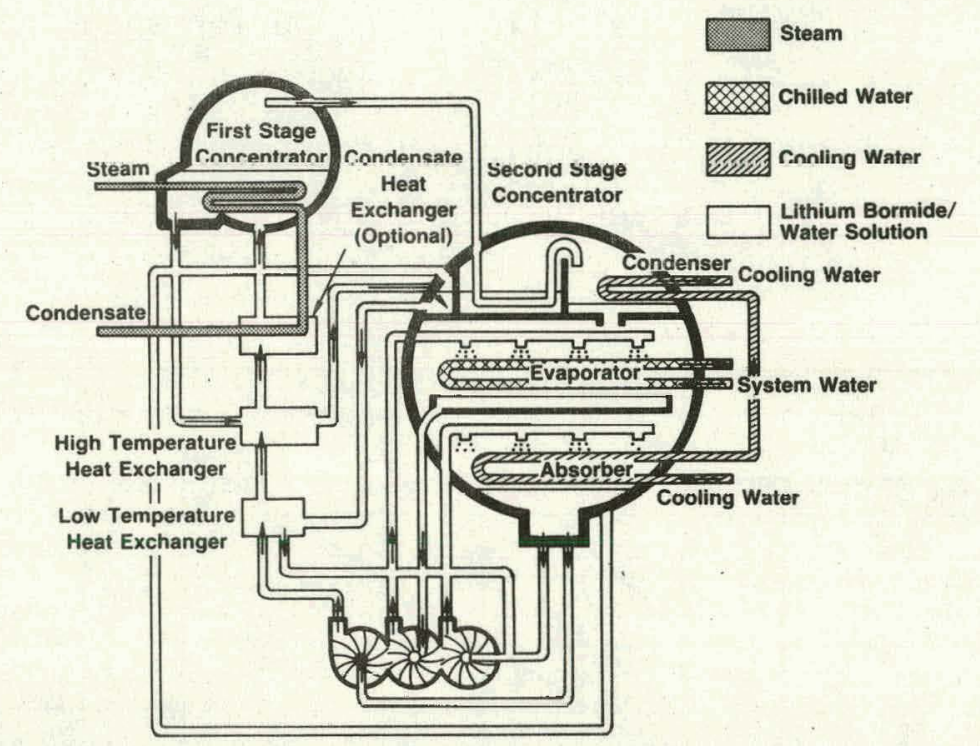

Figure 3.5.4-4. Two-Stage Absorption Cooler Layout

The selected unit is available in stock form and with certain optional equipment. The selection of the optional equipment has not been completed; however, the approximate cost of the overall unit is in the $\$ 220,000$ to $\$ 230,000$ range.

\subsubsection{Steam Generator}

Preliminary specifications for the steam generator subsystem were prepared and submitted to potential heat exchanger suppliers. The preliminary specifications are shown in Table 3.5.5-1. These preliminary specifications call for a steam delivery of $16,400 \mathrm{lb} / \mathrm{hr}$ at $715 \mathrm{psia}, 750^{\circ} \mathrm{F}$, which is equivalent to approximately $18 \times 10^{6} \mathrm{BTU} / \mathrm{hr}$. These initial specifications reflected a duty cycle which was at a slightly lower steam rate than was finally required. 
Table 3.5.5-1. Steam Generator Requirements Fort Hood Solar Cogeneration Plant

Type:

Rating:
Working Fluids:
Code Requirements:
Turndown Ratio:
Operational Characteristics
HITEC Side
Inlet temperature
Outlet temperature
Flowrate (approximate)
Inlet pressure
Allowable pressure drop
hater/Steam
Inlet temperature
Outlet temperature
Flowrate (approximate)
Outlet pressure

TBD

$18 \times 10^{6} \mathrm{BTU} / \mathrm{hr}:$ (non

HITEC, water, steam

ASME Section VIII, Di

TBD

While the latest duty cycle will require a somewhat larger heat exchanger (HX), the difference in size did not affect the selection of the final $H X$.

The specifications were sent to potential suppliers who make several types of steam generators: (1) shell and tube (once-through), and (2) reboiler types, as illustrated on Figures $3.5 .5-1,-2$, and -3 . Quotation were solicited from:

Struthers Wells Company, Warren, Pa.

Yuba Heat Transfer Corp., Tulsa, Ok.

Thermxchanger, Inc., Oakland, Ca. Graham Manufacturing Company, Batayia, N. Y.

Patterson-Kelley Company, East Stroudsburg, Pa.

Concurrent with the determination of available equipment, a separate trade study was completed related to the relative merits of the two basic types 
1

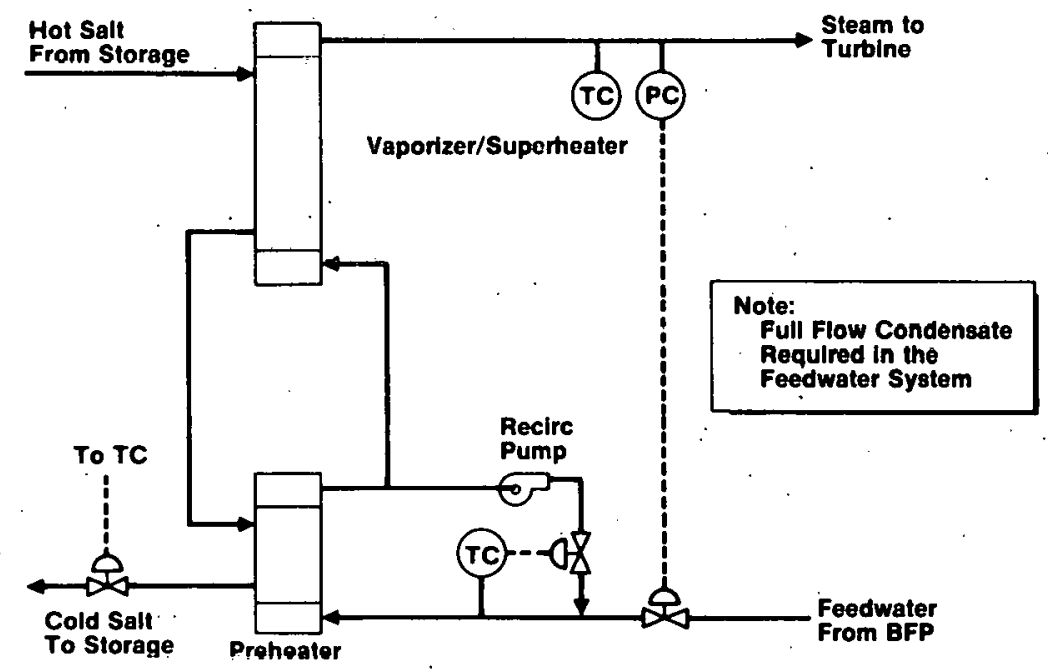

Figure 3.5.5-1. Steam Generator - Once Through

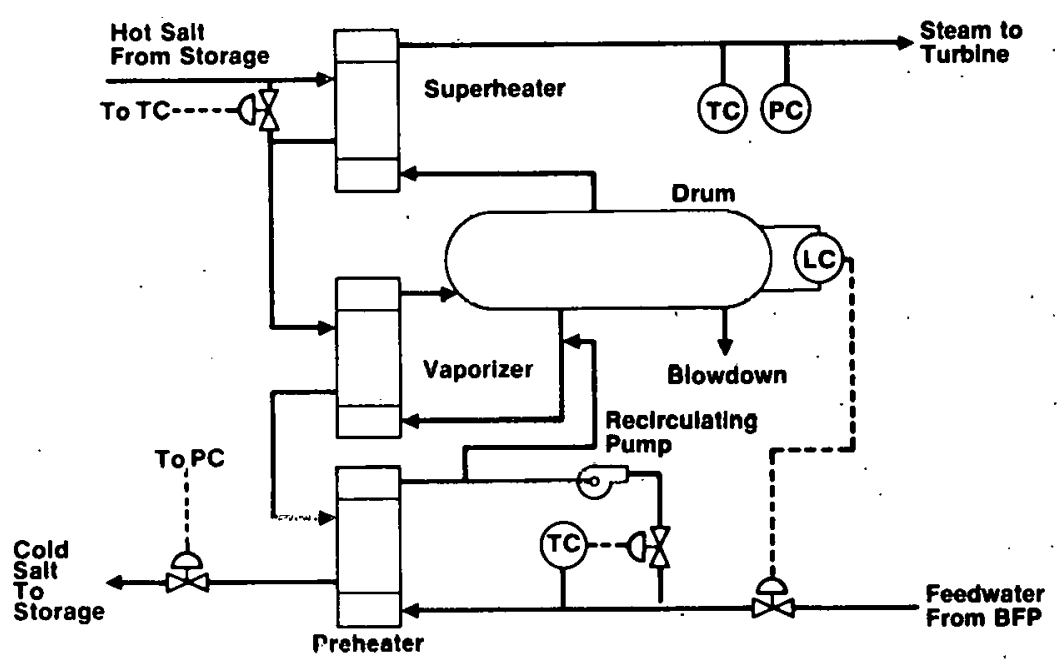

Figure 3.5.5-2. Steam Generator - Separate Drum

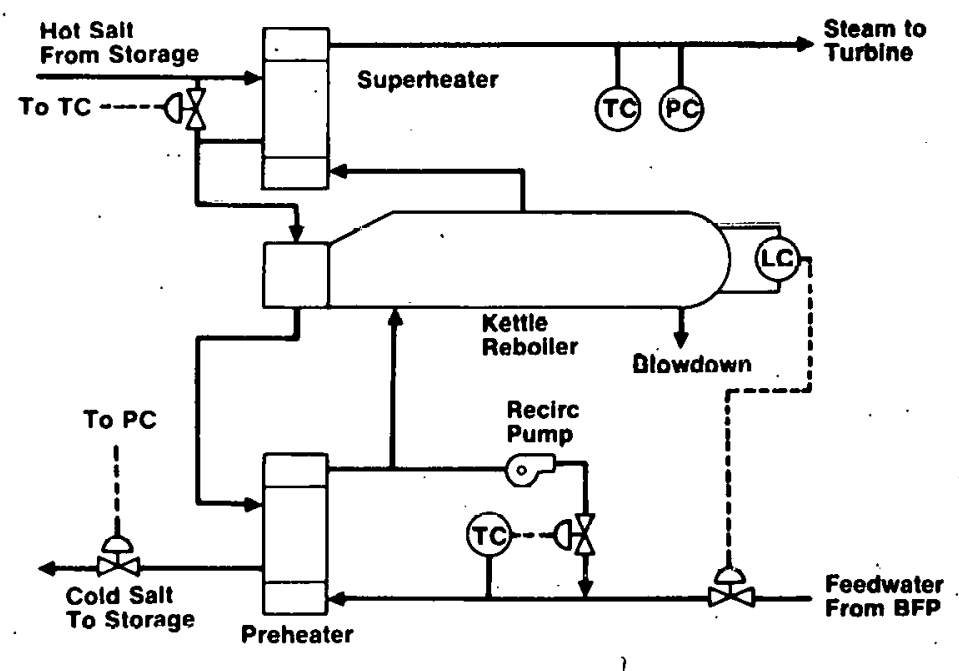

Figure 3.5.5-3. Steam Generator - Kettle Reboiler 
of heat exchangers. This trade study was completed by Stearns-Roger and the results evaluated by MDAC. The results of the $H X$ study indicate that the oncethrough system is less expensive than a reboiler system, but that the water purity requirements are considerably more stringent for the once-through system. While the Curtiss single stage turbine is very insensitive to water purity, the $H X$ is very sensitive and a greater degree of water treatment would be required to prevent fouling in the $\mathrm{HX}$. The fouling rates (versus water purity) for the set of steam conditioning required at Fort Hood have not been firmly established; however, with the amount of superheat specified for this application, it is generally believed that a special water purification would be required for satisfactory system 1 ife for the once-through system. Since no small water purification system is readily available, it would be necessary to develop a new system (for small sizes) or purchase an intermediate size unit. With the intermediate size unit, the cost advantage of the once-through, shell and tube design is more than offset by the cost of the water purification system. Hence, the reboiler type of unit appears to be more cost effective for this application. Many suppliers can supply units which will meet the requirements for this application.

The unit selected for this conceptual design study is a Struthers Wells, kettletype reboiler system. The Struthers design was the only design received that featured the kettle-type of reboiler. This design permits the removal of water impurities by blowing down the evaporator section at timely intervals and this eliminates the need for costly water purification systems. This unit will consist of three separate sections. These sections and their respective heat transfer areas are shown on Figure 3.5.5-4. The estimated cost for the complete unit, less controlier, is $\$ 68,000 \pm 20 \%$.

\subsubsection{Fossil Fueled Heater}

A fossil fueled heater will be required to supply the thermal needs of Complex 87000 when the solar field is unable to collect sufficient energy. The fossil heater will be fired with natural gas. The system can be designed with a large heater, which can maintain full-rated power, or with a small unit which can buffer the solar operation. With the buffer system, the heater supplies enough energy to complete the transition from solar to conventional operation, but this buffer system cannot produce rated turbine power. Since 


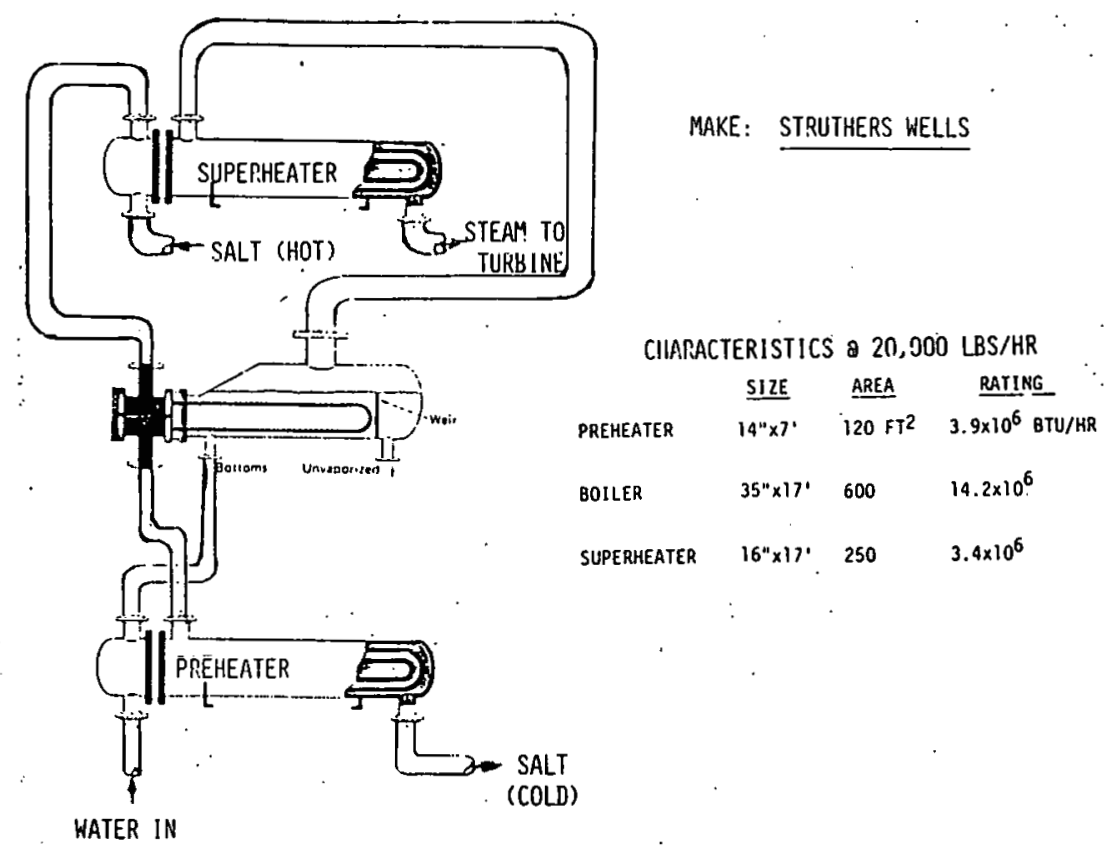

Figure 3.3.5-4. Steam Generator Selection

both systems have been considered for the Fort Hood application, two different sizes of heaters were evaluated. The two sizes studied were a $5 \times 10^{6} \mathrm{BTU} / \mathrm{hr}$ unit for buffer operation and a $15 \times 10^{6}$ BTU/hr unit for rated power output. Preliminary specifications were completed for both sizes of units. These specifications are shown in Table 3.5.6-1.

The fossil fueled heaters are standard designs which are used in a wide variely of applications. They are available from various companies including:

Struthers Wells, Warren, Pa,

Patterson-Kelley Company, East Stroudsburg, Pa.

$A B C 0$ Industries, Abilene, Tx.

BS\&B Uniflux, Inic., Houston, Tx.

Eclipse Lookout Company, Chattanooga, Tenn.

In generd, these machines are made in vertical or horizontal models and all machines are very similar. The Struthers unit has been selected for this application; however, a number of other machines could be used with equal ease. The St.ruthers unit was favored over the other units on the basis of the background experience in HITEC/hot molten draw salts accumulated by Struthers. 
Table 3.5.6-1. Fossil Heater Specification

Design

- Type heater

- Heat exchanger orientation

- Fluid

- Line materials:

- Cold lines

- Hot lines

- Heat transfer rate

Flow Conditions

- Temperature (Nominal)

- Inlet

- Outlet.

- Flow rate

- Maximum

- Minimum

- Pressure

$\quad$ Primary
Gas fired
Vertical (for drainage)
HITEC
Carbon steel
Stainless steel
4.2 MWt (14 x $10^{6}$ BTU/hr)

$260^{\circ} \mathrm{C}\left(500^{\circ} \mathrm{F}\right)$

$454^{\circ} \mathrm{C}\left(850^{\circ} \mathrm{F}\right)$

$50,700 \mathrm{~kg} / \mathrm{hr}(111,800 \mathrm{lb} / \mathrm{hr})$ $6,000 \mathrm{~kg} / \mathrm{hr}(13,200 \mathrm{lb} / \mathrm{hr})$

6.6 Bar (100 psi)
Secondary

Gas fired

Vertical (for drai

HIT̈EC

Carbon steel

Stainless steel

$1.45 \mathrm{MW}_{\mathrm{t}}\left(5 \times 10^{6}\right.$

$260^{\circ} \mathrm{C}\left(500^{\circ} \mathrm{F}\right)$

$454^{\circ} \mathrm{C}\left(850^{\circ} \mathrm{F}\right)$

$17,600 \mathrm{~kg} / \mathrm{hr}(38$, $3,000 \mathrm{~kg} / \mathrm{hr} \cdot(6,6$ 6.6 Bar (100 psi)

The selected operating scenario (full turbine power/idle) indicated the need for the larger, full power, fossil heater and, consequently, a separate buffer heater was not required. The unit selected is the Struthers Fired RadiantConvective heater, size 9CHV24-4. A sketch of this unit is shown in Figure 3.5.6-1. The $14 \times 10^{6} \mathrm{BTU} / \mathrm{hr}$ unit will be approximately $33 \mathrm{ft}$. high without stack and $50 \mathrm{ft}$. to the top of the stack. The heater will be approximately $11 \mathrm{ft} .6 \mathrm{in}$. in diameter and will be mounted on a special concrete foundation. These fossil healers are basically scalcable and they are available in a variety of sizes. The thermal efficiency of these heaters is approximately $85 \%$. The selected heater can heat $14 \mathrm{~kg} / \mathrm{sec}$ of $\mathrm{HITEC}$ from $260^{\circ} \mathrm{C}\left(500^{\circ} \mathrm{F}\right)$ to $454^{\circ} \mathrm{C}\left(850^{\circ} \mathrm{F}\right)$. The Struthers line of heaters covers the $300,000 \mathrm{BTU} / \mathrm{hr}$ to $100,000,000 \mathrm{BTU} / \mathrm{hr}$ range. 


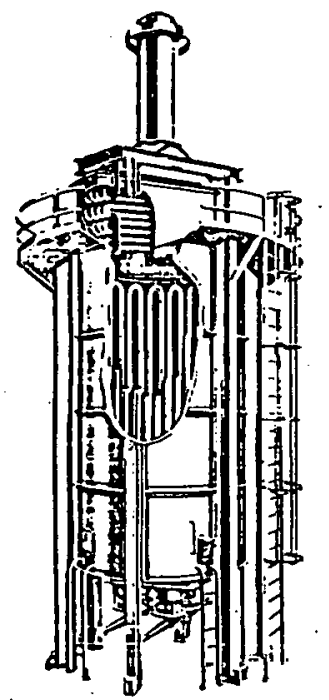

MAKE: STRUTHERS

MODEL: 6CHV16-2-1/2; 9CHV24-4

FLUID: HITEC

OUTLET TEMP, $\quad 454^{\circ} \mathrm{C} \cdot\left(850^{\circ} \mathrm{F}\right)$.

INLET TEMP. $\quad 260^{\circ} \mathrm{C}\left(500^{\circ} \mathrm{F}\right)$

PRESSURE: $\quad 6.6$ BAR (100 PSI)

RATING

MAX. FLOW

$1.45 \mathrm{MW}_{\mathrm{T}}$ (5 NBTU)

$38,850 \mathrm{LB} / \mathrm{HR}$

$4.2 \mathrm{NH}_{\mathrm{T}}$ (14 MBTU)

MIN. FLOH

$6,600 \mathrm{LB} / \mathrm{HR}$

$111,800 \mathrm{LB} / \mathrm{HR}$

HEIGHT (BASIC)

HEIGHT W/STACK

$25^{\prime}$

$13 ; 200 \mathrm{LB} / \mathrm{HR}$

WIDTH

$50^{\circ}$

$33^{\prime}$

$50^{\prime}$

$8^{\prime}-6^{\prime \prime}$

$11^{\prime}-6^{a}$

Figure 3.5.6-1. Auxiliary Heater Selection

The unit sclected was sizcd to an carly set of operating assumptions. The final heater size will be increased to permit a continuous $600 \mathrm{~kW}_{\mathrm{e}}$ turbine/ generator output. This requires a unit that is sized for a HITEC flow rate of $17.4 \mathrm{~kg} / \mathrm{sec}(138,000 \mathrm{lb} / \mathrm{hr})$. This larger rating would represent a therma rating of approximately $6.3 \mathrm{MW}_{t}\left(21 \times 10^{6} \mathrm{BTU} / \mathrm{hr}\right)$, which is well within the range of the standard Struthers units. The cost would be somewhat higher than the value quoted for the $14 \times 10^{6} \mathrm{BTU} / \mathrm{hr}$. As can be seen in Figure 3.5.6-1, the selected design has a primary heat transfer zone which incorporates the vertical radiant walls and a secondary convection zone. This convection zone is located in the top of the hot gas zone and works much like a conventional economizer. This combination provides the correct heat transfer characteristics for the high thermal efficiency quoted.

These units are supplied with a standard control panel and safety system. Optional extras which can be selected for Fort Hood include:
a. Low firc start
b. Iligh and low gas pressure switches
c. Low flow cutoff
d. Automatic relight for on-off control

The basic price of the $14 \times 10^{6} \mathrm{BTU} / \mathrm{hr}$ unit, without accessories, is approximately $\$ 155,000$. 


\subsubsection{Control Automation}

The cost of a full-time operator for a small solar powered plant can be prohibitive. The objective of this trade stidy was to identify the issues associated with automating the plant operations and recommend a design approach for the plant control subsystem. Included were issues that address feasibility, safety, reliability, and economics. The scope of this study was primarily qualitative due to the conceptual design nature of the study. Study emphasis was placed on the more unique elements of the system; i.e., the heliostat field and the molten salt receiver. The other elements of the plant are generally standard and were treated in less detail. Various sources of data were utilized in the study, including the results of previous solar thermal design studies, discussions with Solar 1 and Central Receiver Test Facility personnel, and discussions with equipment suppliers.

The general approach to control automation in this trade study was to minimize plant operating manhours per day without accepting the requirement for total automation until actually operating and maintenance data are available. Facility operators consistently pointed out that each plant must be operated "hands on" for a period of time to discover which system and sequences are subject to nuisance trips, which support systems need to be automated but were forgotten, which remote sensors tended to fail and require extra redundancy, and what the real combinations of environmental conditions and system loads are that must be dealt with. This approach mandates that a plant operator be present for morning startup to perform those tasks which are awkward to automate, to provide fault tolerant reinitialization as required, and to monitor the system operation for maintenance needs. The plant would operate automatically otherwise, including providing protection for the various plant elements, controlling the plant transitions between modes, and controlling the plant operation during input flux transients and output demand transients.

The functions of an automated plant can be grouped into three categories: (1) protection functions, (2) regulation of transients, and (3) optimization of operations. These functions are listed in their correct priorities with protection of personnel and of the plant equipment most important. This function requires redundancy The approach to redundancy was to define as a goal that no single fault will bring down the system, and then identify those 
single fault resources that should surely be redundant. To meet these requirements, each major element of the system must have its own hard wired protection together with plant computer controlled protection. For example, the receiver shall be capable of safing itself through closing the protective doors if the salt pump fails, and the system will safe the receiver through defocusing the heliostat field. The turbine/generator will have the electromotive force of the electrical grid to maintain its speed, but in the event of an electrical trip, it can revert to its own electronically based speed control or to a mechanical governor. After safing, the system will then require selection of alternative sources of power to meet the electrical and thermal load demands. The approach here will be to "fail over" to the electrical grid as a backup for the electrical power, and to activate on the fossil heater as a backup for thermal power. In the event the failure disables the fossil heater/steam generator combination, automatic alarming will alert the base operator who can take appropriate action to minimize the time the system is unavailable.

Regulation of transients, which is the second category of automation functions, is best illustrated by the operation during intermittent insolation periods. The salt receiver control system must sense the time varying insolation and modulate the salt flow to maintain constant outlet salt temperature.

Plant operation optimization, which is the third category of automation functions, requires actual data to support optimization strategies. It is felt that these data will be most efficiently gathered through an actual operating and maintenance experience period. This requires that the plant process computer, which contains the optimization algorithms, must be easily modified (reprogrammed) from the control console.

The recommended approach to plant control features a distributed control system, as shown in Figure 3.5.7-1. The system is shown portioned into six major operating elements which are semi-automatic in operation. This permits the control system to be checked out and tested semi-independently of the other elements, and also provides a framework around which to analyze redundancy requirements. In addition, since the receiver control system has perhaps the 


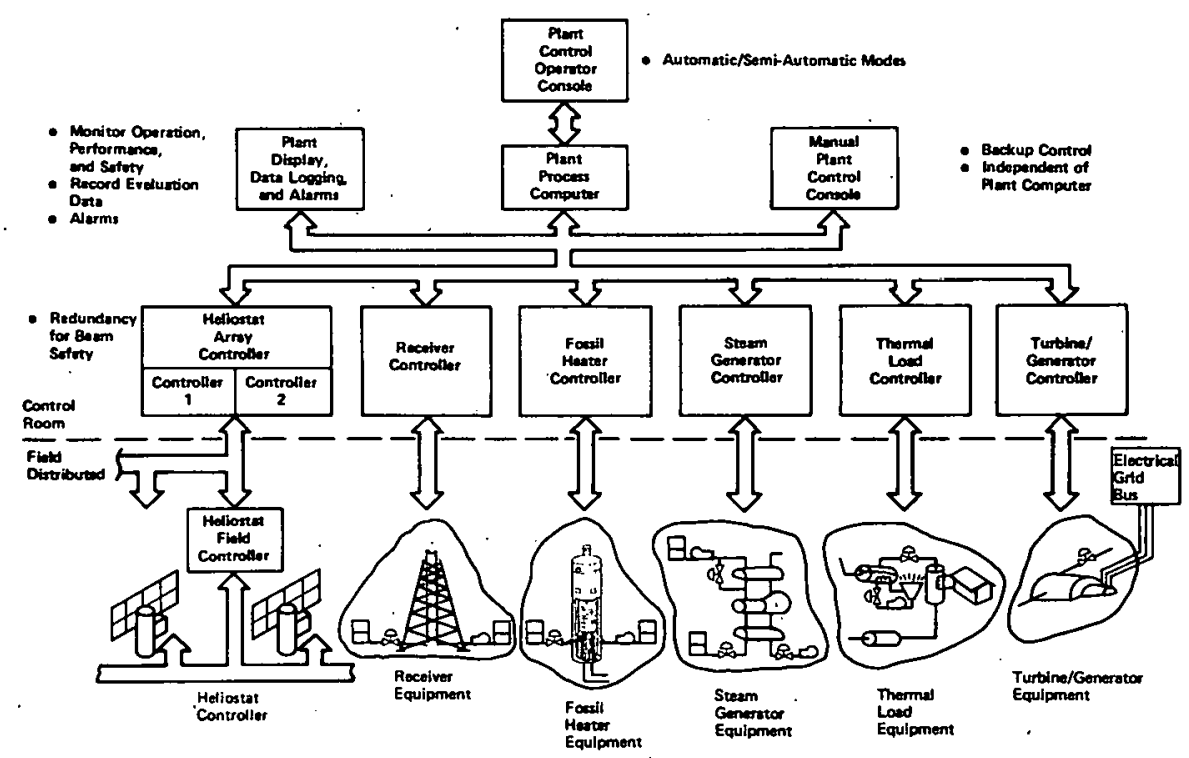

Figure 3.5.7-1. The Plant Control System Features Distributed Controls With Required Redundancy

broadest bandwidth control requirements, a fast sample rate loop closure requirement here will not necessarily mean the other slower elements must also be sampled and commanded at the high rate. The six elements are coordinated through a plant process computer which can be replaced (or bypassed) by a manual operator station for redundancy. The functions of display, data logging, and alarms are also independent of the process computer and the operator console.

To date, the only requirement for redundancy in the computer hardware is related to heliostat beam safety. The heliostat array controller must be redundant because of the personnel safety issue connected with control of the beam. Other redundancy requirements are not clear. In general, the computer and power supply should be redundant due to single point failure sensitivity. other elements need to be analyzed at a detailed level. Prior studies have indicated that rotating equipment (e.g., pumps, turbines, generator, computer disk driver) is much more susceptible to failure and, therefore, the surrounding computer hardware should not be overly redundant since it is not the equipment most likely to fail. Again, this issue must be examined at a detailed level. 
A summary of selected feasibility issues and conclusions considered during this trade study is shown on Table 3.5.7-1 through Table 3.5.7-4, which address the heliostat field, receiver, fossil heater, and turbine/generator, respectively. These results have been incorporated into the design of the plant control subsystem for the Fort Hood solar cogeneration facility.

Table 3.5.7-1. Selected Heliostat Field Automation Issues

ISSUE SUMMARY OF CONCLUSIONS

RESPONSE TO SEVERE WEATHER CONDITIONS (WIND, RAIN, SHOW, HIGH/LOW AMBIENT TEMPERATURES)
NEED WIND SENSOR WITH APPROPRIATE FILTERS TO ESTIMATE AVERAGE WIND SPEED AND RATE OF CHANGE. WINDS > 35 MPH FOR EXTENDED PERIODS OF TIME NEED TO BE SENSED AND F.IELD BROUGHT OUT OF TRACK TO STANDBY; WIND \35 MPH 〈90 MPH REQUIRES FIELD TU BE HORIZONTALLY STOWED. THE HELIOSTAT DESIGN PERMITS ALL OTHER ENVIRONMENTAL CONDITIONS TO BE TOLERATED WITHOUT DROPPING OUT OF THE TRACK OR STANDBY MODES.

RECEIVER DESIGN PERMITS METAL TEMPERATURE RISE RATES CORRESPONDING TO MAX FLUX RISE RATES DURING CLOUD PASSAGE. ESTIMATION OF THE RECEIVER INCIDENT FLUX AS PART OF THE RECEIVER SALT FLOW RATE CONTROL SYSTEM PROVIDES NECESSARY HEAT REMOVAL COMPENSATION. NO MODIFICATION OF HELIOSTAT FIELD CONTROL REQUIRED.

PROVIDE AUTOMATIC HELIOSTAT FIELD PERTURBATION AIM STRATEGY TO REDISTRIBUTE A SMALL AMOUNT $(E, G, ; 10 \%)$ OF HELIOSTAT FLUX BASED ON RECEIVER DISTRIBUTED FLUX MEASUREMENTS; NEED RECEIVER DISTRIBUTED FLUX MEASUREMENTS (E.G., DISTRIBUTED THERMOCOUPLES).
RESPONSE TO RECEIVER

"HOT SPOTS" OR

"COLD SFOIS"
PROVIDE AUTOMATIC HELIOSTAT FIELD FLUX PROPORTIONAL CONTROL STRATEGY WHICH INCREASES/DECREASES HELIOSTATS IN TRACK IN INCREMENTS (E, G, $10 \%$ INCREMENTS).
RECEIVER SAFETY IN THE EVENT OF A SALT PIIMP FAILURE OR LINE BLOCKAGE
SCRAM COMMAND TO FIELD MUST RESULT IN. FLUX REMOVAL RATE SUCH THAT THE RESULTANT INTEGRATED FLUX OVER THE RECEIVER IS LESS THAN 100\% FLUX $X 10$ SECONDS BASED ON RECEIVER THERMAL DAMAGE CRITERIA.
CONTROL OF BEAM DURING POWER OUTAGE
NORMAL POWER SUPPLIED FROM TURBINE/GENERATOR, BACKUP POWER FROM GRID PROVIDES REDUNDANCY 
Table 3.5.7-2. Selected Receiver Automation Issues

ISSUE SUMMARY OF CONCLUSIONS

CONTROL OF SALT TEMPERATURE DURING START-UP ANI THERINE LOW INSCLATID?: CONDITIONS
OPEN RECEIVER DOORS WHEN AVERAGE INSOLATION PREDICTED WILL HEAT HINIMUM SALT FLOW RATE (E.G., 10\% OF RATED FLOW) TO HOT STORAGE TANK TEMPERATURE; NEED INSOLATION METER (E,G,; LANGLEY METER) WITH APPROPRIATE FILTER TO ESTIMATE AVERAGE INSOLATION.

DIVERT MINIMUM SALT FLOW TO COLD STORAGE TANK WHEN SALT OUTLET TEMPERATURE < HOT STORAGE TANK TEMPERATURE.

DEFOCUS HELIOSTAT FIELD AND CLOSE DOORS WHEN SALT TEMPERATURE AT: RECEIVER OUTLET <INLET

NEED SOLAR FLUX SENSOR TO PROVIDE THERMAL TRANSIENT ANTICIPATION AND SALT FLOW RATE COMMAND CONTROL
CONTROL OF SALT

TEMPERATURE DURING

CLOUD PASSAGE ACROSS

HELIOSTAT FIELD
AUTOMATED CONTROL OF DRAIN AND PURGE
AUTOMATED DRAIN AND PURGE NOT REQUIRED BECAUSE OF IDLE MODE... IDLE MODE KEEPS SALT CIRCULATING

Table 3.6.7-3. Auxiliary Heater Automation Issues

ISSUE

PROVIDE SIMPLE AND EFFICIENT CONTROL STRATEGY
SUMMARY OF CONCLUSIONS

- RATED FLOW/ZERO FLOW CONTROL STRATEGY

- FUEL FLOW EITHER FULL-RATEd OR OFF

- -salt flow valve controls OUTLET temperature

- TURN "ON" WHEN hOT SALT STORAGE REACHES A MINIMUM VOLUME

- TURN "OFF" WHEN HOT SALT STORAGE IS RETURNED TO THE CLEAR DAY TRAJECTORY

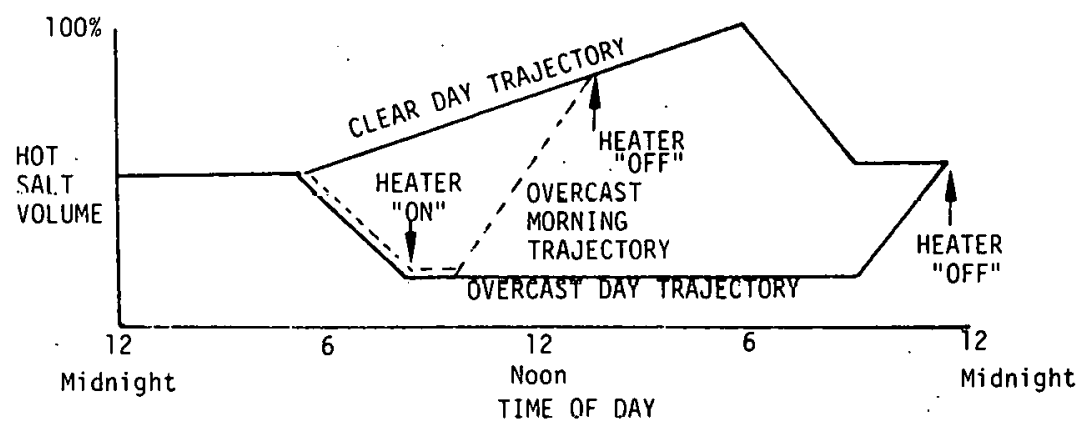


Table 3.5.7-4. Turbine/Generator Automation Issues

ISSUE

SUMMARY OF CONCLUSIONS

CONTROL OF STARTUP

TURBINE WARMUP NOT REQUIRED BECAUSE OF IDLE MODE; NEED TURBINE/ AFTER IDLE THROUGH GENERATOR SPEED CONTROLLER WITH AUTOMATIC SEQUENCING CAPABILITY.

- RAMP SPEED SLOWLY UP TO SYNCHRONOUS SPEED

- SYNCHRONIZE TURBINE/GENERATOR WITH GRID AND CONNECT GENERATOR UNDER NO LOAD CONDITIONS

- SWITCH TO TURBINE/GENERATOR LOAD CONTROL (E.G., TURBINE BACK PRESSURE CONTROL)

- REVERSE SEQUENCE ON COMMAND

CONTROL OF TURBINE/

GENERATOR AFTER

ELECTRICAL LOAD TRIP
INDEPENDENT GOVERNOR TO PROVIDE EMERGENCY BACKUP TO TURBINE CONTROLLER.

RESPONSE TO LOW LUBE

OIL PRESSURE

SPEED CONTROLLER STOPS TURBINE AND ISSUES ALARM

WATER CHEMISTRY

VARIATION

BASELINE DESIGN MINIMIZES CHEMISTRY VARIATIONS

- STEAM GENERATOR/TURBINE WATER CIRCUIT IS ISOLATED

- WATER IS TREATED (SOFT WATER).

- IDLE MODE AVOIDS FULL ON/OFF. TEMPERATURE CYCLING

\subsubsection{Solar Equipment Location}

Because of the collector field azimuth limit imposed by the receiver orientation, heliostats are not located in the southwest corner of the available plot of land. The resulting field layout, therefore, allows sufficient space in this area for locating all the solar plant equipment. This simplifies the situation in that only low pressure steam lines and chilled water lines need to be run from the solar plant to the existing central energy facility in the complex. The high temperature salt piping and receiver feed pump head requirements are minimized by locating the molten salt storage tanks adjacent to the tower and the steam generator (located in the solar power plant). Also located in the power plant building, as indicated in Figure 3.5.8-1, are the turbine generator, absorption chiller, deaerator, air compressor and various pumps. Room is provided for switch gear, water treatment equipment, and the uninterrupted power supply. Chilled water tanks are conveniently located between the chiller and the cooling tower. The pressurized 


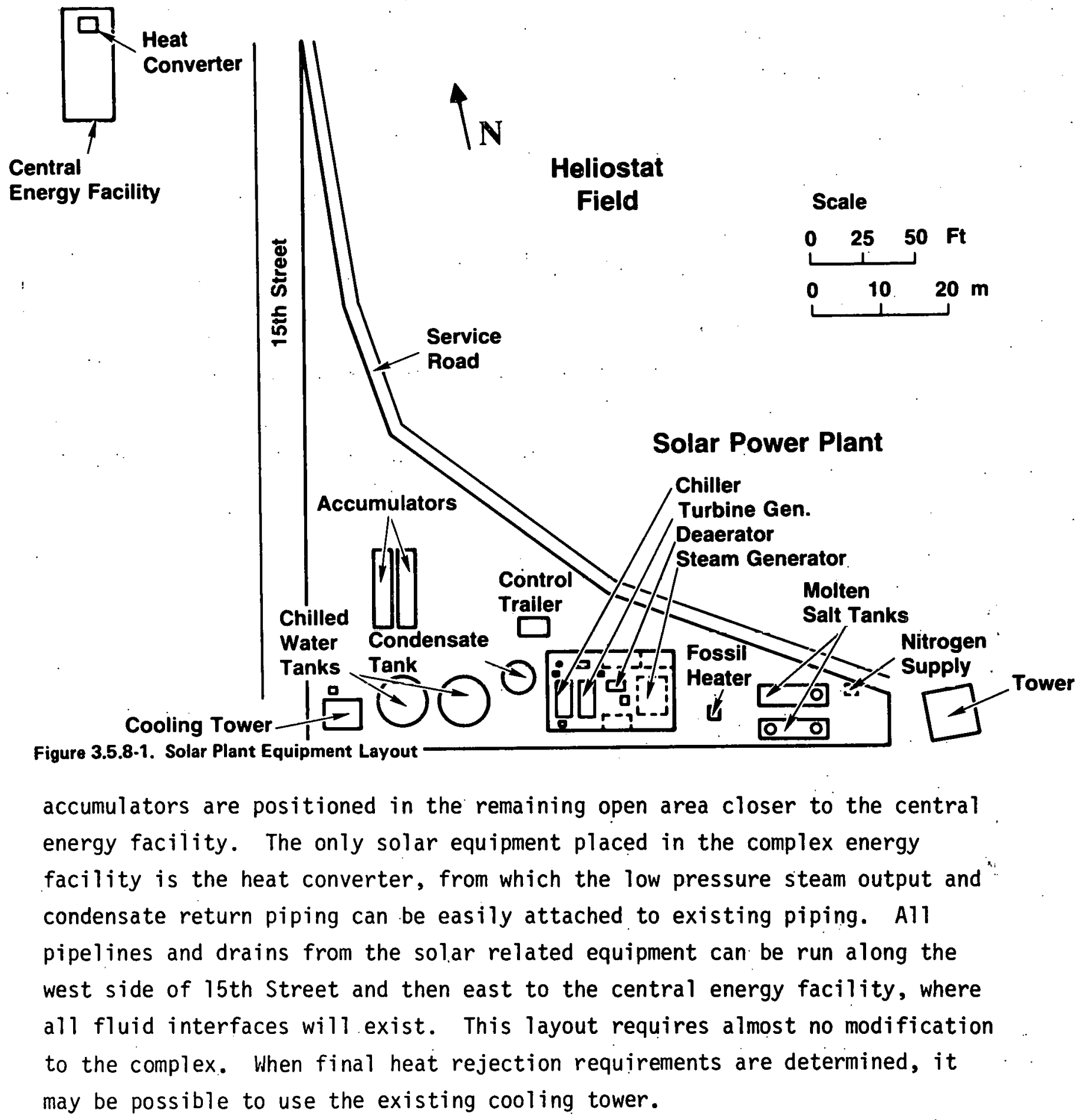




\section{THIS PAGE \\ WAS INTENTIONALLY \\ LEFT BLANK}


Section 4.0

CONCEPTUAL DESIGN

This section presents a system level conceptual design description of the Fort Hood Solar Cogeneration Facility. Subsystem level descriptions are contained in Section 5. These two sections include the results of Tasks 4 (Conceptual Design) and Task 5 (Facility Performance Estimates): Additional supporting data are contained in the appendices.

Conceptual design descriptions of the overall system are currently underway. Facility conceptual descriptions completed to date under Task 3 are contained in Section 3 of this Topical Report. Complete system descriptions will be reported in the final report in accordance with the following subsections.
4.1 System Description
4.2 Functional Requirements
4.3 Design and Operating Characteristics
4.4 Site Requirements
4.5 System Performance
4.6 Energy Load Profile
4.7 Capital Cost Summary for Project
4.8 Operating and Maintenance Costs and Considerations
4.9 Supporting System Analyses 


\section{THIS PAGE \\ WAS INTENTIONALLY \\ LEFT BLANK}


Section 5.0

\section{SUBSYSTEM CHARACTERISTICS}

This section presents conceptual design descriptions of the major subsystems for the Fort Hood Solar Cogeneration Facility. System level descriptions are contained in Section 4.0. These two sections include the results of Task 4 (Conceptual Design). Additional supporting data are contained in the appendices.

Conceptual design descriptions of the subsystems are currently underway, and will be reported in the final report in accordance with the following subsections.

\subsection{Site}

5.2 Site Facilities

5.3 Collector Subsystem.

5.4 Receiver Subsystem

5.5 Tower Subsystem

5.6 Energy Transport and Storage Subsystem

5.7 Fossil Energy Subsystem

5.8 Electrical Power Generating Subsystem

5.9 Plant Control Subsystem

5.10 Space Conditioning Subsystem

5.11 Domestic Hot Water Subsystem

5.12 Specialized Equipment 
THIS PAGE

WAS INTENTIONALLY

LEFT BLANK 
Section 6.0

ECONOMIC ANALYSES

This section presents the results of the facility cost estimates and economic analyses (Task 5). Additional cost and economic data are contained in Section 5 of the System Specification (Appendix A).

Economic analyses efforts for the selected system configuration have just been initiated. Results will be reported in the Final Report in accordance with the following subsections.

\subsection{Method}

6.2 Assumptions with Rationale

6.3 Plant and System Simulation Models

6.4 Results and Conclusions

6.5 Economic Scenario 
THIS PAGE WAS INTENTIONALLY LEFT BLANK 
Section 7.0

DEVELOPMENT PLAN

This section presents the results of the development planning that includes all major activities required during the detailed design, construction and operational phases (Task 6 ). Supporting data are contained in the appendices.

This effort has not yet been initiated. Results will be presented in the final report in accordance with the following subsections.

\subsection{Design Phase}

7.2 Construction Phase

7.3 System Checkout and Startup Phase

7.4 System Performance Validation Phase

7.5 Joint User/DOE Operations Phase

7.6 Schedule and Milestone Chart

7.7 Roles of Site Owner, Government, and Industry 
THIS PAGE

\section{WAS INTENTIONALLY LEFT BLANK}


Section 8.0

USER'S ASSESSMENT

This section presents an assessment by the U. S. Army of the proposed Fort Hood Solar Cogeneration Facility. The information in this section substantiates and augments the summary assessment by the user reported in Section 1.8 of the Executive Summary.

This assessment will be made by U. S. Army personnel or their representatives at the conclusion of the study effort. This assessment will be presented in accordance with the following subsections.

8.1 Endorsement of Project Results

8.2 Endorsement of Project Worth

8.3. Operation, Safety and Environmental Impact

8.4 Product Development Plan and Schedule

8.5 Energy Problems and Planning Strategies

8.6 Alternative Systems

8.7 Institutional and Regulatory Considerations

8.8 Acceptability Assessment 
THIS PAGE

\section{WAS INTENTIONALLY \\ LEFT BLANK}


APPENDIX A

SYSTEM SPECIFICATION 
THIS PAGE

WAS INTENTIONALLY

LEFT BLANK 


\author{
Appendix A \\ System Specification \\ for \\ Fort Hood Solar Cogeneration Facility
}

This appendix contains an updated draft of a System Specification for A Solar Cogeneration Facility at the Fort Hood Army Base in Killeen, Texas. This specification has been prepared by the McDonne11 Douglas Astronautics Company (MDAC) for review and approval by the Department of Energy (DOE) under Contract DE-AC03-81SF11495. This specification has been prepared in general accordance with the reporting instructions as specified in Enclosure III, Exhibit I, Attachment I of DE-RP03-80SF10768.

Since this specification draft exceeds 180 pages, it has been separately bound and submitted with this mid-term Topical Report. This draft will be further updated at the conclusion of the study period and submitted with the Final Technical Report. 
THIS PAGE

WAS INTENTIONALLY :

LEFT BLANK 
APPENDIX B

FINAL REPORT OUTLINE 
THIS PAGE

WAS INTENTIONALLY

LEFT BLANK 


\section{Appendix B}

Final Report Outline

An expanded outline of the final report (Report B.4) for the Fort Hood Solar Cogeneration Facility Study is contained in this appendix. The outline conforms with DOE instructions for all solar cogeneration projects (SNLL letter from J. Anderson, Feb. 5, 1981).

The expanded outline includes page limitations. Volume I, which is limited by DOE to 300 pages, contains an Executive Summary (Section 1) and the main body of the report. (Sections 2 through 8 ). Volume II contains appendices which include the System Specification-and supporting data. Volume II and additional volumes (if required) are limited to 350 pages each. Section 5 of the System Specification is to contain summary technical and detailed economic data. Therefore, appropriate sections of Volume I will include only cost summaries. 


\section{THIS PAGE}

WAS INTENTIONALLY

LEFT BLANK 
Fort Hood Solar Cogeneration Facility Study

Final Report Outline (300 pages)
- Cover
- Title Page
- Distribution
- Abstract (200 words or 1ess)
- Preface
- Acknowledgements
- Table of Contents
- Definitions and Abbreviations

Section 1.0 EXECUTIVE SUMMARY (23 pages)

1.1 General Introduction

1.2 Facility Description

1.3 Project Summary

1.4 Conceptual Design Description

1.5 System Performarice

1.6 Economic Findings

1.7 Development Plan

1.8 Site Owner's Assessment

Section 2.0 INTRODUCTION (24 pages)

2.1 Study Objective

2.2 Technical Approach and Site Selection

2.3 Site Location

2.4 Site Geography

2.5 Climate

2.6 Existing Plant Description

2.7 Existing Plant Performance

2.8 Project Organization

2.9 Final Report Organization

Section 3.0 SELECTION OF PREFERRED SYSTEM (52 pages)
3.1 Introduction
3.2 System Configuration
3.3 Technology
3.4 System Size
3.5 Trade Studies

Section 4.0 CONCEPTUAL DESIGN (66 pages)

4.1 System Description

4.2 Functional Requirements

4.3 Design and Operating Characteristics

4.4 Site Requirements

4.5 System Performance

4.6 Energy Load Profile

4.7 Capital Cost Summary for Project

4.8 Operating and Maintenance Costs and Considerations

4.9 Supporting System Analyses 
Section 5.0 SUBSYSTEM CHARACTERISTICS (103 pages)
5.1 Site
5.2 Site Facilities
5.3 Collector Subsystem
5.4 Receiver Subsystem
5.5 Tower Subsystem
5.6 Energy Transport and Storage Subsystem
5.7 Fossit Energy Subsystem
5.8 Electrical Power Generating Subsystem
5.9 Plant Control Subsystem
5.10 Space Conditioning Subsystem
5.11 Domestic Hot Water Subsystem
5.12 Specialized Equipment

Section 6.0 ECONOMIC ANALYSES (15 pages)
6.1 Method
6.2 Assumptions with Rationale
6.3 Plant and System Simulation Models
6.4 Results and Conclusions
6.5 Economic Scenario

Section 7.0 DEVELOPMENT PLAN (10 pages)

7.1 Design Phase

7.2 Construction Phase

7.3 System Checkout and Startup Phase

7.4 System Performance Validation Phase

7.5 Joint User/DOE Operations Phase

7.6 Schedule and Milestone Chart.

7.7 Roles of Site Owner, Government, and Industry

Section 8.0 USER'S ASSESSMENT (7 pages)

8.1 Endorsement of Project Results

8.2 Endorsement of Project Worth

8.3 Operation, Safety and Environmental Impact

8.4 Product Development Plan and Schedule

8.5 Energy Problems and Planning Strategies

8.6 Alternative Systems

8.7 Institutional and Regulatory Considerations

8.8 Acceptability Assessment

Appendix A SYSTEM SPECIFICATION (Volume II)

Appendix $B$ SUPPORTING DATA (Volume III)

B. 1 Insolation Characteristics

B.2 Collector Field Optimization

B.3 Energy Demand Requirements

B.4 System Sizing Analyses

B.5 Facility Design Interfaces and Modifications

B.X (Others as required) 
Fort Hood Solar Cogeneration Facility Study

Final Report Expanded Outline ( 300 pages)

Pages

- Cover . . . . . . . . . . . . . . . . . .

- Title Page.

- Distribution

- Abstract (200 words or less).

- Study objectives and scope

- Study team and approach

- Facility concept

- Study products

- Major conclusions \& recommendations

- Preface . . . . . . . . . . . . . . . . . . . .

- Acknowledgements. . . . . . . . . . . . . . . . .

- Table of Contents . . . . . . . . . . . . . . . . .

- Definitions and Abbreviations

1.0 EXECUTIVE SUMMARY . . . . . . . . . . . . (23)

1.1 General Introduction. . . . . . . . . . . . . . . 3

- Background information (DOE, DOD, MDAC, Other)

- Study objectives and scope

- Technical approach, study tasks and products

- Study. team and organization

- Facility photo/artist concept

1.2 Facility Description ............... 2

- Site (location, geographic, climate)

- Facilities (buildings, land, central plant)

- Energy services (power, heat, air conditioning)

1.3 Project Summary ............... . . 3

- Programmatic conclusions

- Technical conclusions

- Economic conclustons

1.4 Conceptual Design Description.......... 4

- Overview description

- Facility arrangement

- Conceptual design summary (DOE table)

1.5 System Performance. . . . . . . ...... 4

- Energy requirements

- Irisolation available

- Facility cycle efficiencies

- Energy capabilities versus requirements

- Energy savings 
1.6 Economic Findings... . . . . . . . . . . . . 3

- Economic assumptions

- Capital and O\&M cost summary

- Present value results

- Economic conclusions

1.7 Development Plan. . . . . . . . . . . . . . 2

- Development phases

- Development schedule

- Development plan conclusions

1.8 Site Owner's Assessment . . . . . . . . . . . . . 2

- Endursement of project results

- Assessment of project worth

- Operation, safety and environmental impact/benefits

- Project development plan and schedule

- Energy problems and planning strategies

- Alternatives to solar cogeneration systems

- Institutional and regulatory considerations

- Acceptability assessment

- (Cross reference to Section 8.0) 
Page

2.0 INTRODUCTION . . . . . . . . . . . . . . . . . .

- Title of study

- Contract number

- Contract cast

- Period of performance

- Prime contractor principal investigator

- Prime contractor mailing address

2.1 Study Objective . . . . . . . . . . . . . . 0.5

- Prime study objectives

- Program goals

2.2 Technical Approach and Site Selection

2.2.1 Approach . . . . . . . . . . . . . . . .

- Study tasks and scope

- Task flow

- Task schedule and major milestones

- Task outputs/products

- Subcontractor support

2.2.2 Site Selection...............

- Selection of Ft. Hood Army Base

- Selection of Complex 87000

2.3 Site Location . . . . . . . . . . . . . . . . . 2

- Location of Killeen, Texas

- Fort Hood layout

- Complex 87000 location

- Complex 87000 layout

2.4 Site Geography

2.4.1 Site Topography . . . . . . . . . . . . . . 1

- Latitude and longitude

- Elevation

- Terrain features

- Soil conditions

- Drainage

- Earthquake zones

2.4.2 Plant Location

- Solar facility arrangement

- Collector field constraints

- Solar equipment 'locations

- Helicopter field interfaces 
2.5 Climate

2.5.1 Solar Insolation. ............. 3

- Data sources, analyses and comparisons

- Average monthly and yearly insolation

- Standard deviations and extremes

- Clear day insolation (solstice, equinox)

- Cloudy day characteristics

- Values for design and performance analyses

- (Detailed information in Appendix B.1)

2.5.2 Meteorological Data .............

- Data sources

- Normal, means and extremes of temperature, rain, snow, wind, gusts, humidity, clouds, hail, etc.

- Storms (dust, tornadoes, lightning)

- Design values

- (Detailed data in Appendix B.1 and System Spec.)

2.6 Existing Plant Description

2.6.1 Central Energy Plant. . . . . . . . . . . . .

- General description \& history

- Power grid interface with base

- Gas line interface with base

- General controls and operational aspects

2.6.2 Electrical Power Distribution System. . . . . .

- General description

- Power distribution network

- Meters and controls

2.6.3 Air Conditioning System ............ 2

- General description

- Electrical interfaces

- Vapor compressors

- Chilled water lines

- Building distribution system

- Room conditioners

- Water return lines and equipment

- Cooling tower

- Meters and controls

2.6.4 Room Heating \& Domestic Hot Water Systems . . . . 2

- General description

- Gas line interfaces

- Boilers

- Steam lines

- Heat exchanger system

- Hot water distribution system

- Room heaters

- Hot water circulation system

- Condensate return lines \& equipment

- Meters and controls 
Pàge

2.7 Existing Plant Performance

2.7.1 Energy Demands. . . . . . . . . . . . . 2 '

- Daily, monthly, annual average demands

- Baseline electrical power

- Air conditioning power

- Room heating

- Domestic hot water

- Variations from average

- (Detailed information in Section 4.6 and Appendix B.3)

2.7.2 Availability/Outages. . . . . . . . . . . . 1

- Annual operational times/availability

- Number and duration of scheduled outages

- Unscheduled outages and major causes

2.7 .3 O\&M Requirements. . . . . . . . . . . 0.5

- Type of O\&M support (1abor, materials)

- Annual 0\&M requirements

- Levelized 0\&M costs over plant life

2.8 Project Organization . . . . . . . . . . . . . . 1

- Team members

- Roles and responsibilities

- Study organization

2.9 Final Report Organization. . . . . . . . . . . . 0.5

- Section identification

- Appendix information 
3.0 SELECTION OF PREFERRED SYSTEM . . . . . . . . . . . .

- Organization and content of section

- Cross reference to other sections and appendices

3.1 Introduction . . . . . . . . . . . . . . . . .

- Selection process description

- Selection criteria and rationale

- Site specific considerations

3.2 System Configuration . . . . . . . . . . . . .

3.2.1 Configuration Options . . . . . . . . . . 2

- Candidate system configurations

- Candidate components

3.2.2 Preferred System Concept. . . . . . ... . . .

- Identification of selected concept

- Selection rationale (including economic and non-economic influences)

\subsection{Technology}

\subsubsection{System Development Risk Assessment}

- General technology status

- Development risks

- Critical test requirements

3.3.2 Receiver Fluid Risk Assessment. . . . . . . . . .

- Fluid candidates and characteristics

- System needs

- Site owner's preference

- HITEC selection

- Techiology status and risks

3.3.3 Receiver Configurations Risk Assessment . . . . 2

- Design history of candidate receiver concepts

- System needs

- Configuration selection

- Readiness of technology for demonstration projects

3.4 System Size. . . . . . . . . . . . . . . .

\subsubsection{Collector Field Sizing}

- General requirements and limitations

- Optimization process description

- Heliostat design (type, quantity, arrangement, constraints, performance efficiencies)

- Tower design (free standing or guyed, location, height, impact on field layout and receiver pump, interface with military base/airfield)

- Receiver design (aperture size, field angle, flowrates, outlet temperature, efficiencies)

- Cost impact

- Total energy collection capabilities and efficiencies

- (Refer to Appendix B.2 for detailed data) 
3.4.2 Solar System Sizing. . . . . . . . . . 7

- General system requirements

- Candidate system configurations \& operating modes

- System capabilities versus demands

- Subsystem performance requirements (collector field power, auxiliary heating, high temp. storage, low temp. storage, capacities, temperatures, pressures, flowrates, usage profiles, etc.)

- Modifications to existing equipment \& facilities

- Economic evaluations

- Selection of preferred system approach and size

- (Refer to Appendix B.4 for detailed data)

3.5 Trade Studies . . . . . . . . . . . . .

- List of trade studies, objectives and issues

- Reference to appendices, as appropriate

3.5.1 Turbine/Generator Equipment. . . . . . . . . . . 4

- General requirements

- Candidate equipment (type, size, modif.)

- Performance (power rating, extraction and backpressure capabilities, efficiencies)

- Operational characteristics (usage profiles, startup and shutdown features)

- Equipment availability and cost data

- Selection of preferred equipment

3.5.2 High Temperature Storage . . . . . . . . . . . . 3

- General requirements

- Candidate storage concepts (type, size, temp.)

- Performance (capacity; relationships to field size, turbine rating and low temp. storage; heat losses)

- Operational characteristics (usage profiles)

- Cost data (tank, insulation, HITEC, equipment)

- Selertion of preferred approach

3.5.3 Low Temperature Storage ............ . 3

- General requirements (hot water, chilled water)

- Candidate approaches (central tanks, remote tanks, no storage tanks)

- Performance (temp., capacity, tank sizing)

- Operational characteristics (usage profiles)

- Availability and cost data

- Selection of preferred equipment 
3.5.4 Air Conditioner Unit.............. . 3

- General requirements

- Candidate equipment (type, size, modif.)

- Performance capabilities (capacity, efficiencies)

- Operational characteristics (usage profiles)

- Availability and cost data

- Selection of preferred equipment

3.5.5 Steam Generator. . . . . . . . . . . . .

- General requi rements

- Candidate equipment (type, size, modif.)

- Performance capabilities (capacity, range of flowrates, efficiencies)

- Operational characteristics (usage profiles)

- Availability and cost data

- Selection of preferred equipment

3.5.6 Fossil Fueled Heater . . . . . . . . . . . 3

- General requirements

- Candidate equipment (type, size, modif.)

- Performance (capacity, efficiencies)

- Operational characteristics (usage profiles)

- Availability and cost data

- Selection of preferred equipment

3.5.7 Plant Control Automation .............

- General requirements

- Candidate approaches (type, modif.)

- Operational characteristics (extent of manned operations of heliostats, steam boiler, turbine, water purity, electrical power generation and general operations)

- O\&M cost impact

- Equipment availability and cost

- Selection of preferred approach

3.5.8 Solar Equipment Location .............. . 3

- General requirements and limitations

- Candidate locations (turbine/generator, thermal storage tanks, fossil fueled heater, air conditioning unit, controls, heat rejection)

- Performance impact (thermal losses, collector field losses from cooling tower, pumping losses)

- Operational impact (integration with existing plant, 0\&M activities)

- Design and cost impact (pumping, lines, drainage, insulation, trace heating) 


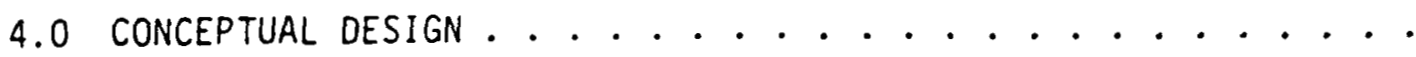

- Organization and content of section

- Cross reference to other sections and appendices

4.1 System Description

4.1.1 Solar System Description . . . . . . . . . .

- Artist rendition (photo overlay)

- Facility equipment arrangement

- System schematic/flow diagram

- (Detailed engineering drawings in Appendix B.5)

4.1.2 Base Facility Interfaces . . . . . . . . . .

- General arrangement at Complex 87000

- Summary of major interfaces with base facilities (refer to Section 4.4.3)

4.2 Functional Requirements . . . . . . . . . . . .

4.2.1 System Performance Requirements . . . . . . . .

- Electrical power

- Thermal energy

- Storage

- Conversion efficiencies

4.2.2 System Design Life Requirements . . . . . . . . .

- Design life/availability goals

- DOD service life limitations

4.2.3 Design Points . . . . . . . . . . . . 0.5

- Design conditions (max./min. insolation, flux)

- Rationale for component design

4.2.4 Instrumentation and Control Requirements . . . . .

- Central control station philosophy

- Manned/automated control philosophy

- Safety requirements

4.3 Design and Operating Characteristics...........

Multi-page tabular summary of key design/operating

characteristics for the selected system (receiver

type, receiver size, tower height, tower type, number of heliostats, heliostat size, storage type, turbine type, fossil boiler type, materials, temperatures, pressures, powers, flow rates, neak fluxes, peak temperatures, heat rates, etc.)

4.3.1 Operating Modes ..................

- Energy collection (solar-only, fossil heater only, hybrid)

- Energy utilization (electric power-only, electric/ thermal power, thermal power-only)

- Transitional (startup, intermittent, normal shutdown, emergency stop)

- Standby/inactive (overnight, maintenance, extended shutdown) 


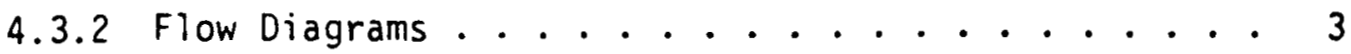

- Piping and instrumentation diagram (P\&ID)

- Operating conditions (pressures, temp., flowrates)

4.3.3 Thermal Energy Balance.............. 2

- State point conditions

- Annual. energy balance

4.3.4 Instrumentation and Controls. . . . . . . . . . 2

- Network

- Redundancy and safety features

4.4 Site Requirements. . . . . . . . . . . (15)

- Reference to detailed drawings in Appendix B.5

4.4.1 Site Preparation. . . . . . . . . . . . . . 4

- Site properties (location, geographic characteristics, site restrictions/limitations)

- Site preparations (grading, surfacing, drainage, piping, cableways, foundations, roads, parking lots, walkways, fencing, general utilities, area lighting)

4.4.2 Site Facilities . . . . . . . . . . ... . . 4

- Plant control trailer and provisionings

- Solar equipment housing

- Storage and maintenance

- Facility services (fire, lightning, utilities)

4.4.3 Soiar/Existing Plant Interfaces. . . . . . . . . 5

- Structural interfaces/modifications

- Mechanical interfaces/modifications

- Electrica? interfaces/modifications

4.4.4 Site Plot Plan. . . . . . . . . . . . . . . 2

- Site plot plan identifying major solar system

elements, plant interfaces, and site constraints

4.5 System Performance . . . . . . . . . . . . (5)

- Reference to supporting analyses in Appendix B.4

4.5.1 System Efficiency . . . . . . . . . . . . . 3

- Energy collection efficiency

- Energy conversion efficiency

- Efficiency diagrams (for design points and annual average) 
4.5.2 Fuel Displacement . . . . . . . . . . 2

- Current fuel usage (type, quantity)

- Fuel displaced by solar facility (daily, monthly, antually)

- Equivalent energy savings (methodology and values)

4.6 Energy Load Profiles . . . . . . . . . . . . . (7)

4.6.1 Energy Demand Profiles. . . . . . . . . . . . 3

- Average energy demand diagrams for electricity, room conditioning and domestic hot water (daily, monthly, annually)

- Variations from average demands (also summarized in Section 2.7.1)

4.6.2 Energy Usage Profiles . . . . . . . . . . 4

- Energy dispatch strategy

- Solar energy utilization (collection, hightemperature storage, low-temperature storage, spillage)

- Auxiliary heating requirements from gas-fired boiler

- Electrical power utilization (requirements from grid; surplus to grid)

4.7 Capital Cost Summary . . . . . . . . . . . .

- Reference to System Specification (Section 5.3) for basis of cost estimating and backup cost sheets

4.7.1 Facility Costs. . . . . . . . . . . .

- Summary of cost assumptions

- Cost-code boundary zones by subsystem shown on functional system schematic and geographic plot plan

- Summary costs per DOE cost elements (includes costs of equipment, engineering, construction, indirects, contingencies, fee, etc.)

4.7.2 Owher's Costs . . . . . . . . . . . . . .

- Summary costs per DOE cost elements (includes costs of land, environmental studies, public interface support, taxes, insurance, consumables, cost of money, etc.)

4.8 Operating and Maintenance Costs and Considerations . . . . . (2)

4.8.1 Normal O\&M Costs ................ . I

- Labor costs (operations, maintenance)

- Supplies, materials, spare parts

4.8.2 Special Considerations. . . . . . . . . . . . .

- Special staffing costs

- Training costs

- Speciar equipment costs 
4.9 Supporting System Analyses . . . . . . . . . . (12)

- Reference to supporting data in Appendix $B$

4.9.1 Reliability/Availability. . . . . . . . . . . 1

- Failure modes and effects

- Annual reliability/availability analyses (downtime and time to repair)

- Impact on design and maintenance approach

4.9.2 Maintainability . . . . . . . . . . ..... . 1

- Scheduled maintenance plan

- Unscheduled maintenance impact

- Maintenance support requirements

4.9.3 Producibility . . . . . . . . . . . . . . 1

- Long lead time components

- Production requirements

- Equipment and facility needs

- Delivery assessment

4.9.4 Installation. . . . . . . . . . . . . . 2

- Installation requirements

- Checkout testing requirements

- Special equipment and personnel needs

4.9.5 Logistics Support . . . . . . . . . . . . . 2

- Transportation and handling

- Maintenance and spares provisioning

- Personnel and training

4.9 .6 Safety. . . . . . . . . . . . . . . . 2

- Equipment design (requirements, codes, design safety factors)

- Plant operations (safety procedures, warning devices)

- Local operations (aircraft, glare; noise, fire, explosions, etc.)

4.9.7 Environmental Impact. . . . . . . . . . . . . 1

- Natural environments (geological, water, air quality, climate, plants, animals)

- Human environments (general land usage, traffic, employment, economic, archaeological)

4.9.8 Institutional, Regulatory, and Other Considerations . . 2

- Electric company considerations (power demands, tie-in, phasing, switching, surplus sell-back, agreements)

- Gas company consideration (gas demands, tie-in, agreements)

- Army base considerations (building codes, permits, safety standards)

- Community considerations (building codes, permits, safety standards) 
5.0 SUBSYSTEM CHARACTERISTICS . . . . . . . . . . . .

- Identification of major subsystems

- Cross reference to Appendices for detailed data

5.1. Collector Subsystem (CS) . . . . . . . . . . .

- Subsystem function

- Identification of major elements

- Physical location

5.1.1 CS Functional Requirements. . . . . . . . .

- Total energy incident to receiver

- Incident flux and spillage requirements

- Overall efficiency

5.1.2 CS Design and Performance Characteristics.....

5.1.2.1 Collector Field (3)

- Arrangement

- Performance (energy delivered, flux, spillage efficiency)

5.1.2.2 Heliostats (4)

- Element descriptions (mirror modules, reflector assembly, drive units, pedestal, foundation, $H C, H A C$, power and control cabling)

- Performance (reflectivity, beam quality, pointing error, surface deflections, overall efficiency)

5.1.3 CS Operating Characteristics. . . . . . . . .

- Energy collection mode

- Transitional modes (startup, intermittent, normal shutdown, emergency shutdown, standby, inactive)

5.1.4 CS Trade Studies. . . . . . . . . . . . .

- (Other than Section 3.0)

5.1.5 CS Cost Summary ..............

- Capital costs

- O\&M costs 
5.2 Receiver Subsystem (RS). . . . . . . . . .

- Subsystem function

- Identification of major elements

- Physical location

5.2.1 RS Functional Requirements. . . . . . . . . 0.5

- Receiver fluid

- Energy absorbed and delivered

- Overall efficiency

5.2.2 RS Design and Performance Characteristics . . . . 8

\subsubsection{RS Absorber Assembly (6)}

- Element, descriptions (coils, piping, manifolds, vent valves, insulation, heaters)

- Performance (inlet and outlet conditions, pressure drop, absorbed energy, thermal losses, efficiency)

\subsubsection{RS Supporting Assemblies (2)}

- Housing assembly (supports, doors)

- Riser and downcomer piping

- Controls (cabling, instrumentation)

5.2.3 RS Operating Characteristics. ........... 3

- Energy collection mode

- Transitional modes (startup, intermittent, normal shutdown, emergency shutdown, standby, inactive)

5.2 .4 RS Trade Studies. . . . . . . . . . . 0.5

- (Other than Section 3.0)

5.2 .5 RS cost Summary ............. . . 0.5

- Capital costs

- O\&M costs 
5.3 Tower Subsystem (TS). . . . . . . . . . .

- Subsystem function

- Identification of major elements

\section{)}

0.5

- Physical location

5.3.1 TS Functional Requirements .......... 0.5

- Height

- Receiver support weight

- Deflection/sway limits

5.3.2 TS Design and Performance Characteristics. . . . . 4

5.3.2.1 Tower Assembiy (2)

- Structure

- Foundation

- Guy wires (if used)

5.3.2.2 Tower Accessories

- Ladders and service elevator

- Working platforms and supports

- Lightning protection

- Lights and utilities (power, water)

- Heliostat alignment target

5.3.3 TS Operating Characteristics (Not Applicable) ... 0

5.3.4 TS Trade Studies............. . 0.5

- (Other than Section 3.0)

5.3.5 TS Cost Summary. . . . . . . . . . 0.5

- Capital costs

- O\&M costs 
5.4 Energy Transport and Storage Subsystem (ETSS). . . . . . .

- Subsystem function

- Identification of major elements

- Physical location

5.4.1 ETSS Functional Requirements.

0.5

- Operating conditions (pressure, temp. flowrates)

- Storage energy capacity (high-temp: storage)

- Efficiencies

5.4.2 ETSS Design and Performance Characteristics . . . . 12

5.4.2.1 Energy Transport Assembly (4)

- Element descriptions (piping, valves, actuators, pumps, insolation, trace heaters, instrumentation)

- Performance (temp., pressures, flowrates, pressure heads, pressure losses, thermal losses, puin speeds, puwer requirements, efficiencies)

\subsubsection{Storage Tanks (4)}

- Element descriptions (tanks, insulation, heaters, vent/relief valves, storage media, nitrogen purge, instrumentation)

- Performance (storage temp., pressure, fluid/gas volumes, charge/discharge rates, thermal losses, power requirements, efficiencies)

\subsubsection{Steam Generator (4)}

- Element descriptions (generator unit; piping, valves, insulation, trace heaters, instrumentation)

- Performance (temp., pressures, flowrates, pressure losses, thermal charge/discharge rates, thermal losses, power requirements, efficiencies)

5.4.3 ETSS Operating Characteristics. . . . ....... 3

- Energy collection mode

- Energy utilization mode

- Transitional modes (startup, intermittenl, nürnal shutdown, emergency shutdown, standby, inactive)

5.4.4 ETSS Trade Studies. . . . . . . . . . . . 0.5

- (Other than Section 3.0)

5.4.5 ETSS Cost Summary ............... 0.5

- Capital costs

- O\&M costs 
5.5 Fossil Energy Subsystem (FES) . . . . . . . .

- Subsystem function.

- Identification of major elements

- Physical location

5.5.1 FES Functional Requirements. . . . . . . . .

- Thermal energy capacity

- Operating conditions (pressure, temp., flowrates)

- Efficiency

5.5.2 FES Design and Performance Characteristics .....

5.5.2.1 Heater Assembly (2)

- Element description (reactor, heat exchanger, exhaust stack, control valves, instrumentation)

- Performance (inlet and outlet conditions, heat transfer rite, thermal leakage, power requirements, efriciencies)

5.5.2.2 Heater Accessories (1)

- Structural support

- Fuel supply and piping

- Insulation and trace heaters

5.5.3 FES Operating Characteristics. .........

- Energy collection mode

- Energy utilization mode

- Transitional modes (startup, intermittent, normal shutdown, emergency shutdown, standby, inactive)

5.5.4 FES Trade Studies. . . . . . . . . . . . .

- (Other than Section 3.0)

5.5.5 FES Cost Summary ..............

- Capital costs

- O\&M costs 
5.6 Electrical Power Generating Subsystem (EPGS). . . . . . . .

- Subsystem function

- Identification of major elements

- Physical location

5.6.1 EPGS Functional Requirements ...........

- Electrical power rating

- Thermal energy delivery capabilities

- Efficiencies

5.6.2 EPGS Design and Performance Characteristics. . . .

\subsubsection{Power Generation Assembly (3)}

- Element descriptions (turbine, gearbox, generator accessories, instrumentation, controls)

- Performance (inlet/outlet conditions, extraction conditions, RPM, power output and requirements, thermal losses, efficiencies)

\subsubsection{Steam/Feedwater Equipment (4)}

- Element descriptions (condensor, water tower, feedwater heaters, deaerators, water treatment, piping, insulation, trace heaters, pumps control valves, instrumentation.)

- Performance (operating conditions, heat rates, capacities, thermal and pressure losses, power requirements, efficiencies)

\subsubsection{Electrical Power Distrihution Network. (3)}

- Element description (power lines, switches, breakers, transformers, auxiliary power supply, instrumentation)

- Performance (power output, voltage, amperage, power losses, efficiencies)

5.6.3 EPGS Operating Characteristics . . . . . . . .

- Energy collection mode (not applicable)

- Energy utilization mode (electric power-oniy, electric/thermal power mode, thermal poweronly mode)

- Transitional modes (startup, intermittent, normal shutdown, emergency shutdown, standby, inactive)

5.6.4 EPGS Trade Studies ............. 0.5

- (Other than Section 3.0)

5.6.5 EPGS Cost Summary. . . . . . . . . . . 0.5

- Capital costs

- O\&M costs 
5.7 Plant Control Subsystem (PCS) . . . . . . . .

- Subsystem function

- Identification of major elements

- Physical location

5.7.7 PCS Functional Requirements. . . . . . . . . . 0.5

- Control functions

- Monitoring, detection and alarm functions

- Display, printing and recording

5.7.2 PCS Design and Performance Characteristics . . . . 12

5.7.2.1 Control Equipment (9)

- Element description (plant process controller, central control unit, interlock logic system, heliostat field controller, heliostat controllers, unit controllers, instrumentation, control consoles, displays, keyboards, printers, platters, storage devices)

- Performance (control type, capacity, redundancy, power requirements, storage memory, voltages)

5.7.2.2 Control Software (3)

- Heliostat control

- Plant process control

- Priority sequencing logic

- Emergency operations

- Manual override logic

- Diagnostic checkout

5.7.3 PCS Operational Characteristics. . . . . . . . 3

- Automatic operation

- Semi-automatic

- Manual

5.7.4 PCS Trade Studies. . . . . . . . . . . . 0.5

- (Other than in Section 3.0)

5.7.5 PCS Cost Sumary . . . . . . . . . . . . . 0.5

- Capital costs

- O\&M costs 
5.8 Space Conditioning Subsystem $(\mathrm{SCS}) \ldots \ldots \ldots$

- Subsystem function

- Identification of major elements

- Physical location

5.8.1 SCS Functional Requirements........... 0.5

- Room heating and cooling thermal energy capacity

- Demand duty cycle

- Thermal storage capacity

- Backup thermal energy provisions

5.8.2 SCS Design and Performance Characteristics. . . . . 6

5.8.2.1 Room Heating Equipment (3)

- Element description (steam lines, condensate lines, heat exchangers, hot water lines, storage tanks, insulation, pumps, room conditioners, instrumentation, iontrols)

- Perfornance (operating conditions, therima 1 capacities and storage, thermal losses, power requirements, efficiencies)

\subsubsection{Room Cooling Equipment (3)}

- Element description (chilled water lines, return ines, heat exchangers, storage tanks, insulation, pumps, room conditioners, instrumentation, controls)

- Performance (operating conditions, thermal capacities and storage; thermal losses, power requirement, efficiencies)

5.8.3 SCS Operational Characteristics ... . . . . . . 1

- Normal operating modes (energy utilization)

- Backup operating mode

5.8.4 SCS Trade Studies . . . . . . . . . . . . 0.5

- (Other than Section 3.0)

5.8 .5 scs cost Summary. . . . . . . . . . . . . 0.5

- Capital costs (modification costs)

- O\&M costs 
5.9 Domestic Hot Water Subsystem (DHWS) . . . . . . . . (6)

- Subsystem function

- Identification of major elements

- Physical location

5.9.1 OHWS Functional Requirements .......... 0.5

- Hot water thermal capacity

- Demand duty cycles

- Thermal storage capacity

- Backup thermal energy provisions

5.9.2 DHWS Design and Performance Characteristics. . . . . 3

- Element description (heat exchanger, hot water lines, storage tanks, insulation, pumps, room conditioners, instrumentation, controls)

- Performance (operating conditions, thermal capacities and storage, thermal losses, power requirements, efficiencies)

5.9.3 DHWS Operating Characteristics ........... 1

- Normal operating mode

- Backup operating mode

5.9.4 DHWS Trade Studies . . . . . . . . . . . . 0.5

- (Other than Section 3.0)

5.9.5 DHWS cost Summary. . . . . . . . . . 0.5

- Capital costs (notification costs)

- O\&M costs 
5.10 Specialized Equipment. . . . . . . . .

- Identification of major items

- Physicz? location

5.10.1 Equipment Functional Requirements. . . . 0.5.

- Availability

- Functional capabilities

5.10.2 Equipment Design and Performance Characteristics. . . . . . . . . . 1

5.10.2.1 Vehicles

- Mobile crane

- Service truck

- Heliostat washer

5.10.2.2 Maintenance Equipment

- Tools

- Checkout/calibration gear

- Handling fixtures, work platforms, \& ladders

5.10.3 Equipment Operating Characteristics. .... 0

(Not applicable)

5.10.4 Equipment Trade Studies. . . . . . . . 0 (Olher than Section 3.0)

5.10 .5 Equipment Cost Summary ... . . . . . 0.5 


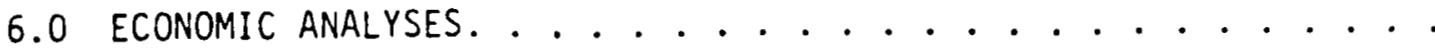

- Scope of economic analyses

- Cross reference to cost data in Specification

- Section topics

6.1 Method ....................

- Approach (DOE methods, DOD methods)

- Parameters incorporated

- Degree of accuracy and uncertainty

6.2 Assumptions and Rationale............

- Capital costs (construction costs and owner's costs by total and fiscal year; cross reference to backup data in System Specification, Section 5.3)

- O\&M costs (labor and material/spares costs by total and fiscal year)

- Fuel costs (current and escalated costs of electrical power, gas and oil)

- Solar facility performance efficiencies

- Other economic assumptions (year dollars, inflation rates, discount rates, capital recovery factors, investment tax credits, income tax rates, energy credits, amortization periods, years of capital investment, operational years, energy conversion factors)

6.3 Plant and System Simulation Model ..........

\subsubsection{Facility Performance Model (1)}

- Key parameter values

- (Cross reference to model description in System Specification, Section 5.5)

\subsubsection{Economic Model (1)}

- Key parameter values

- (Cross reference to model description in System Specification, Section 5.5)

6.4 Results and Conclusions ..............

6.4.1 Annual Fuel Savings (1)

- Power.

- Gas

- Equivalent barrels of oil

\subsubsection{DOE Economic Evaluation (3)}

- Levelized costs

- Rate of return

- Cost payback periods

- Projected worth

- Cost/benefit ratios

- Busbar energy costs

- Fiscal cash flow 
6.4.3 DOD Economic Evaluation (3)

- Amortization periods

- Energy-to-cost ratios per yearly investment costs

- Benefit/cost ratios

6.4.4 Comparative Costs with Alternate Energy Options

- Comparative costs of current systems

- Comparative costs with competitive systems

6.5 Economic Scenario . . . . . . . . . . . .

- Results of other studies that would make the proposed cogeneration system economically attractive to the user.

- Target goals for solar component costs (e.g., heliostats)

- Realistic economic projections considering market forces, fuel cost escalations, inflation rates, etc.

- Solar system capabilities and user preferences relative to the economic benefits of changing the electric to thermal ratio.

- Factors that can significantly increase the viability of solar commercialization. 
7.0 DEVELOPMENT PLAN . . . . . . . . . . . . . . . . .

- Objectives and scope

- Major program guidelines and limitations

- General approach

- Section topics.

7.1 Design Phase. ....

- Phase objectives

- Scope of activities (preliminary design, detailed design, development testing)

- Major milestones

- Key documentation (subsystem procurement specifications, construction packages, environmental impact reports, other)

- Development tests (test plan, test item procurement/ fabrication, test facility preparation, instrumentation, test support, evaluation and reporting)

- Identification of long lead items for next phase

- Roles and responsibilities (prime contractor, subcontractors, DOE, DOD, other)

\subsection{Construction Phase.}

- Phase objectives

- Scope of activities (engineering integration, site development, subsystem fabrication, assembly and installation)

- Permits/approvals for site preparation, facility modification and plant construction

- Major milestones

- Long lead procurements

- Critical path analyses

- Roles and responsibilities

7.3 System Checkout and Startup Phase. . . . . . . . . . . .

- Phase objectives

- Scope of activities (subsystem checkout, system checkout, startup plans)

- Key checkout efforts or procedures

- Major milestones

- Roles and responsibilities

7.4 System Performance Validation Phase. . . . . . . . . 0.5

- Phase objectives

- Scope of activities

- Key validation tests or procedures

- Major milestones

- Documentation

- Roles and responsibilities 
7.5 Joint User and DOE Operations Phase . . . . . . . . . . . 1

- Phase objectives

- Scope of activities (operations, maintenance, repair, training, engineering/economic assessments)

- Operating period and major review milestones

- Roles and responsibilities

7.6 Schedule and Milestone Chart. . . . . . . . . . . . 2

- Phasing schedule of all phases

- Major milestones

- Schedule critical path and backup plans

7.7 .Roles of Site Owner, Government and Industry. . . . . . . . 1

- objectives and limitations

- Major participants

- Division of responsibility, authority and risk sharing

- Cost flow considerations

- Cost. sharing arrangement.s

- Guarantees 


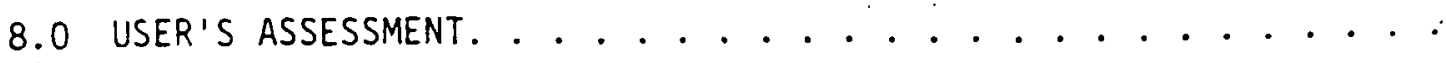

- (Expansion of comments in Section 1.8)

Q.1 Endorsement of Project Results

- Energy supply and demand data

- Cogeneration system feasibility

- Operating and maintenance approach

- Economics

8.2 Endorsement of Project Worth

- DOD evaluation criteria (energy/cost ratio, benefit/cost ratio, amortization, payback period)

- Expansion potential at Complex 87000

- Additional opportunities at Ft. Hood base

- Opportunities at other military bases

8.3 Operation, Safety and Environmental Impacts

- Operation and maintenance capabilities versus requirements

- Helocopter safety interfaces

- Environmental impact

8.4 Product Development Plan and Schedule

- Realism of plan and schedule

- Compatibility with long range plans at Fort Hood

8.5 Energy Problems and Planning Strategies

- Problems facing site owner/user

- Planning compatibility of proposed system

8.6 Alternative Systems

- Alternatives to solar cogeneration system

- Acceptability of central receiver solar technology

8.7 Institutional and Regulatory Considerations

- Federal/military regulations

- Fort Hood Army base regulations

- Other institutional considerations

8.8 Acceptability Assessment

- DOD/Fort Hood acceptance

- Local community acceptance

- Risk assessment

- Guarantees

8.9 (Other comments or criticisms) 


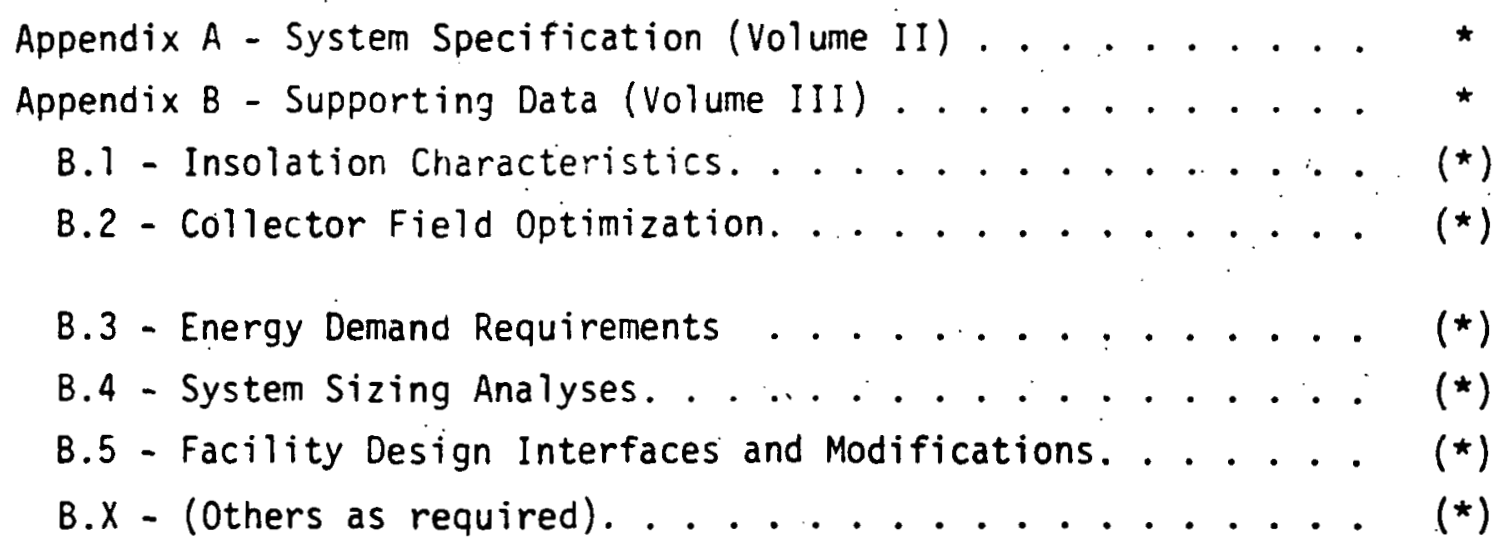

* Page allocation as required; additional volumes limited to 350 pages each. 


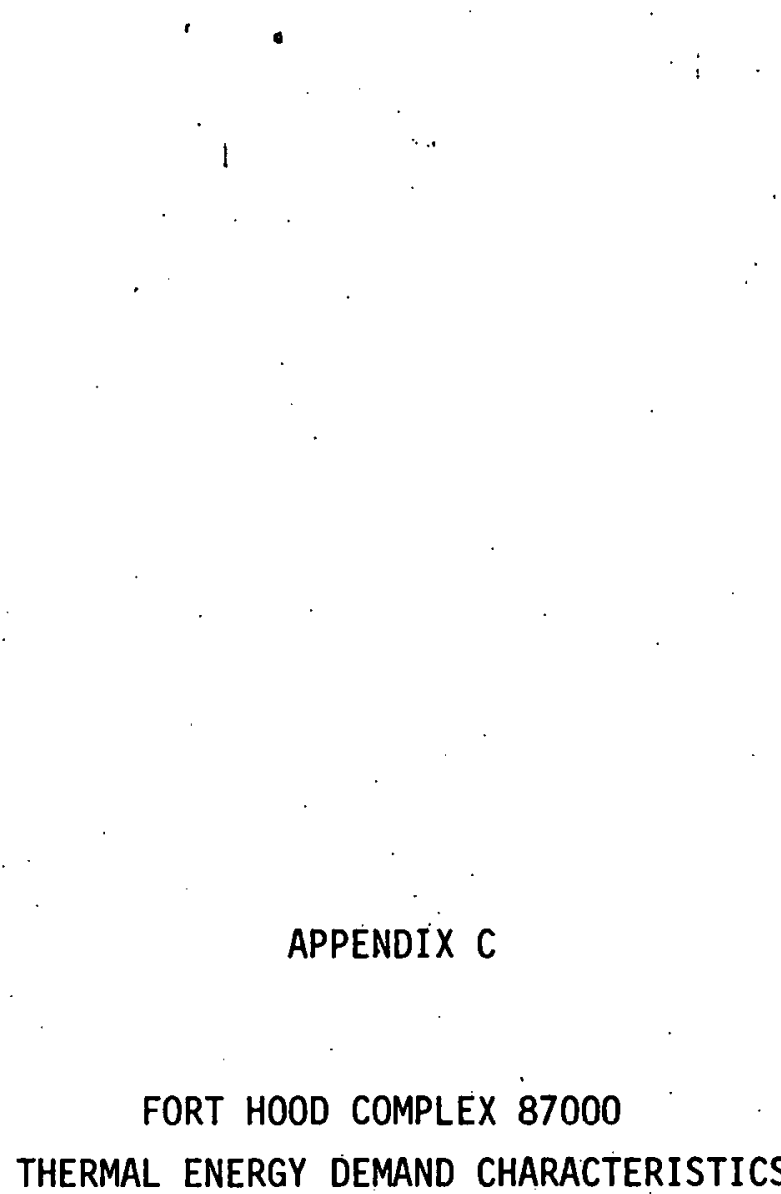

THERMAL ENERGY DEMAND CHARACTERISTICS 


\section{THIS PAGE \\ WAS INTENTIONALLY \\ LEFT BLANK}

152 


\section{Appendix $\dot{C}$ \\ Fort Hood Complex 87000 Thermal Energy Demand Characteristics}

This appendix contains hourly estimates of thermal energy demands at Complex 87000 for a typical day in each month of the year. The days were developed from information presented in "Electricity and Natural Gas Consumption at Fort Hood," American Technological University, Phase I Report, Vol. I, March 31, 1975, and updated to reflect related information contained in "Fort Hood Solar Total Energy Project," American Technological University Preliminary Design, Vol. II, January 1979. Additional data were supplied by the Construction Engineering Research Laboratory (CERL), which performed an hourly survey of electric and gas usage at Complex 87000 from November 1976 to September 1978 under contract to the Army. These data have been further adjusted to reflect the latest operating procedures by DOD personnel at Fort Hood relative to room conditioning periods. 
Figure $\mathrm{C}-1$. Typical January Day Demands

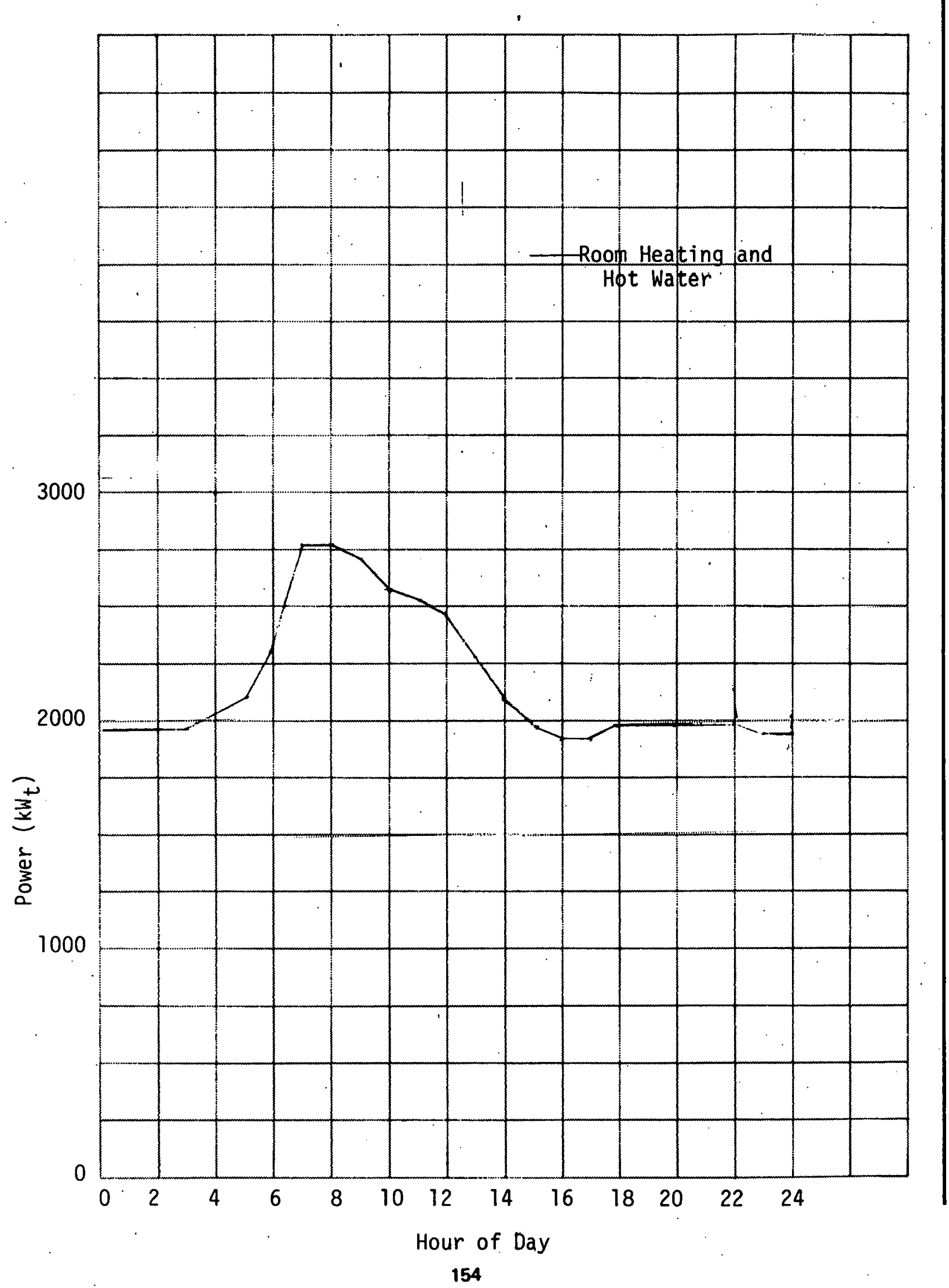


Figure C-2. Typical February Day Demands

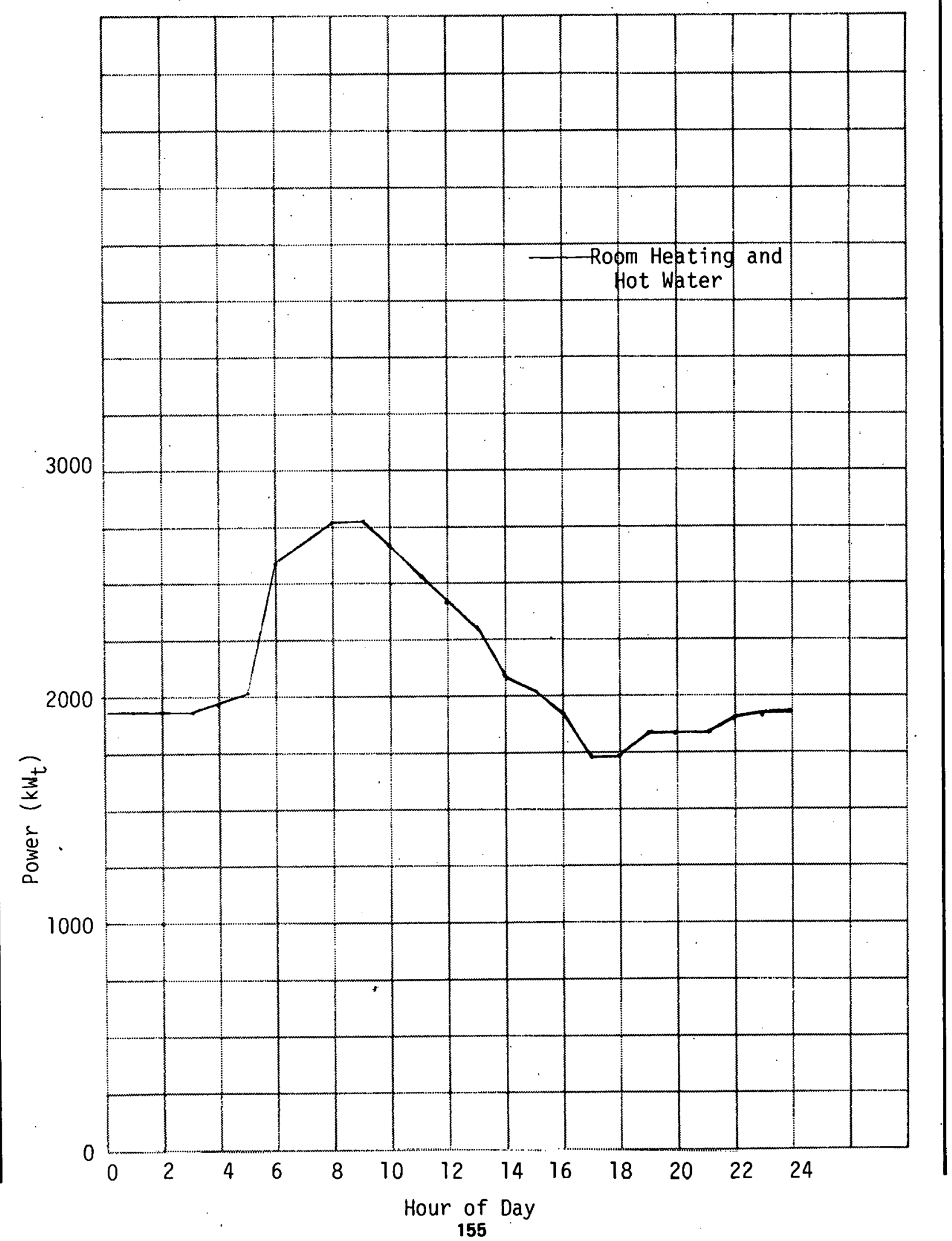


Figure C-3. Typical March Day Demands

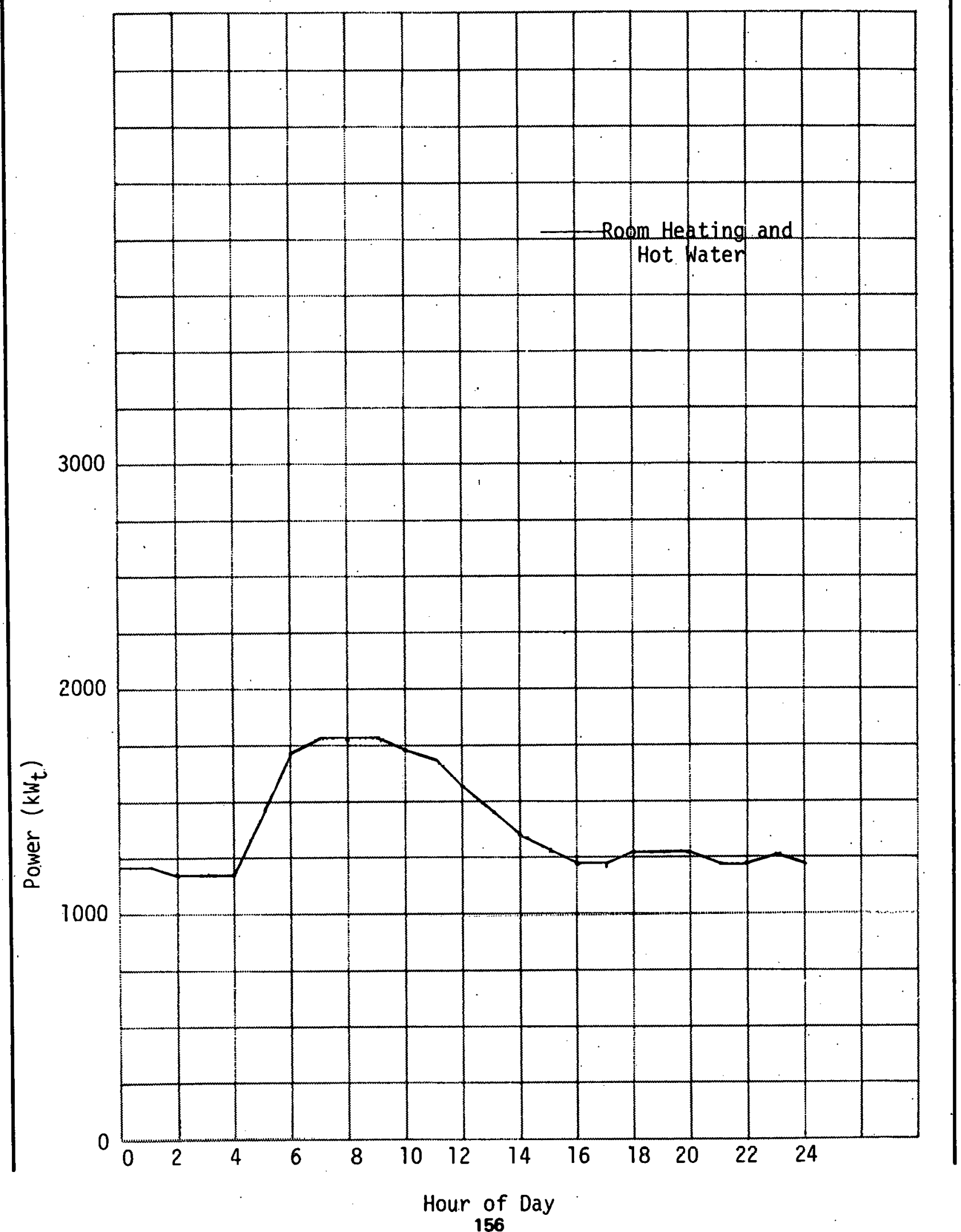


Figure C-4. Typical April Day Demands

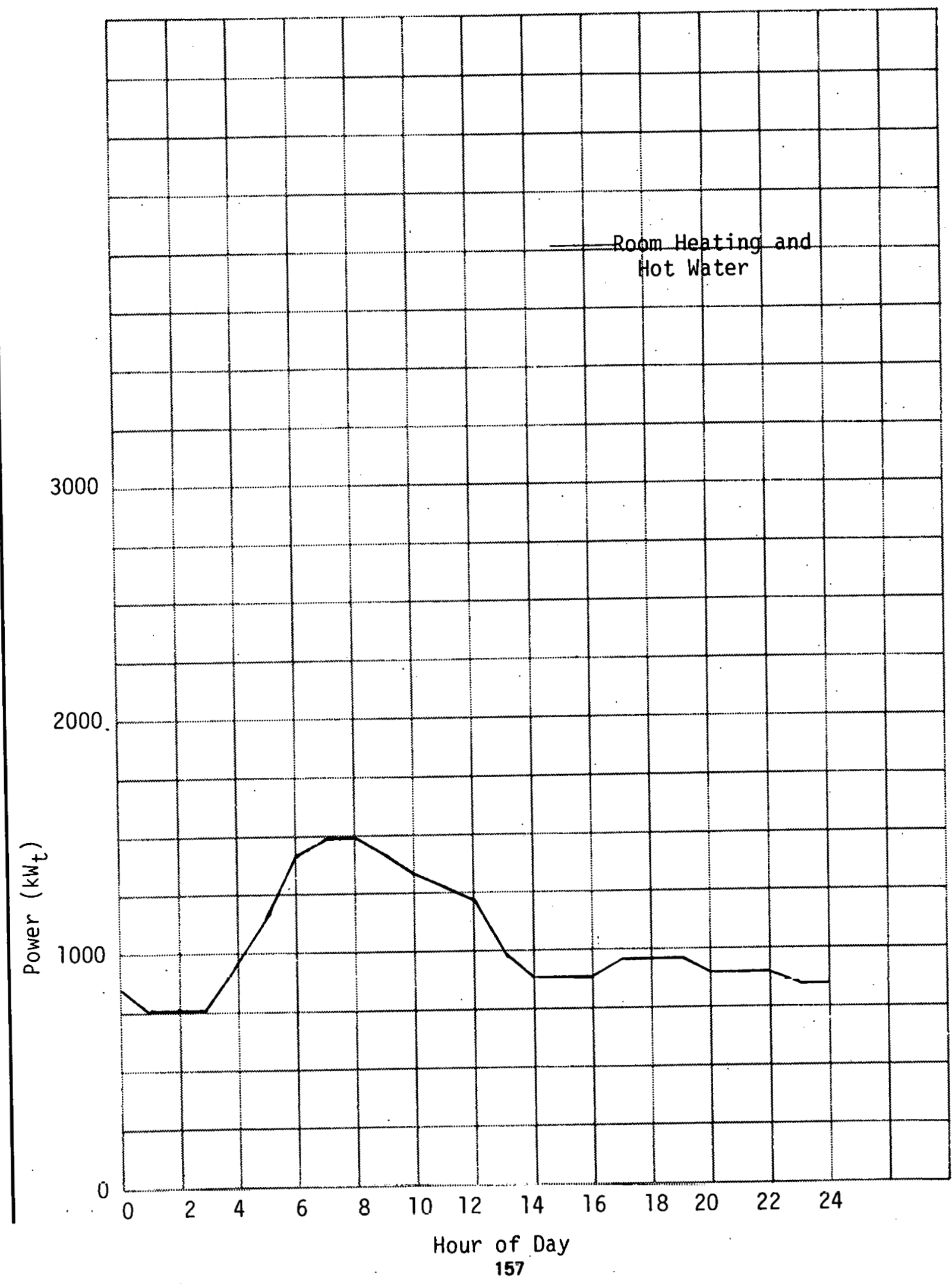


Figure C-5. Typical May Day Demands

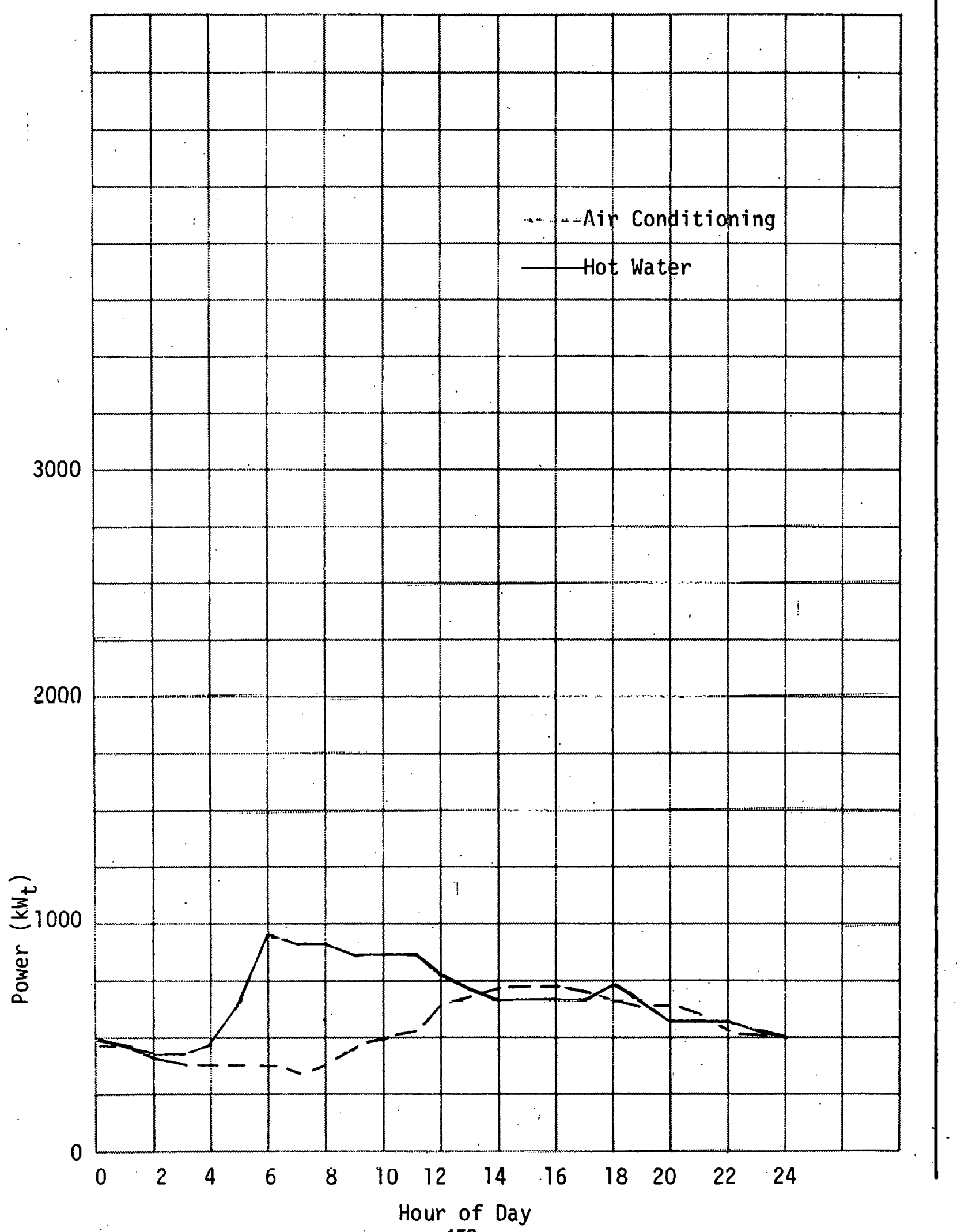


Figure C-6. Typical June Day Demands

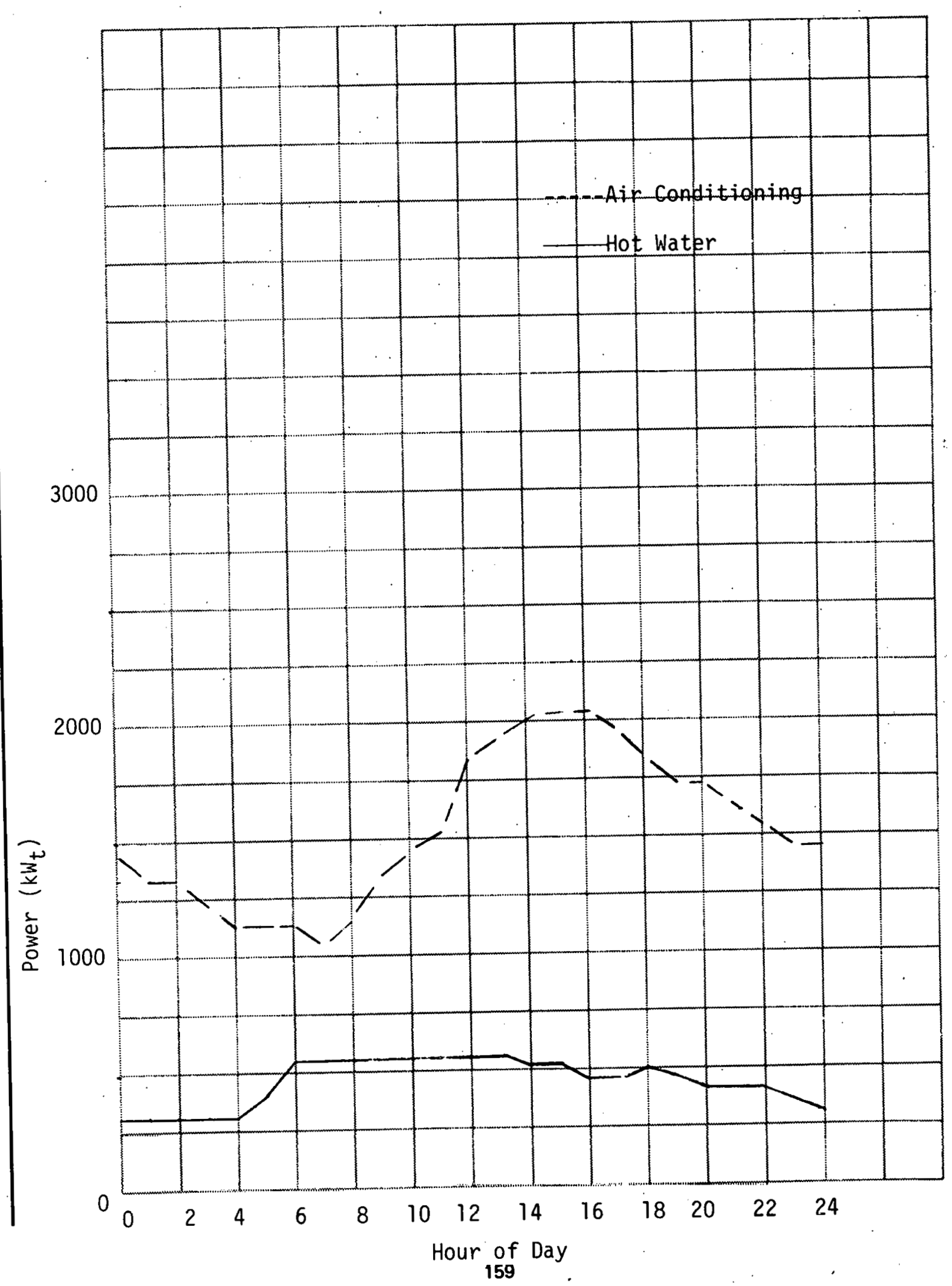


Figure C-7. Typical July Day Demands

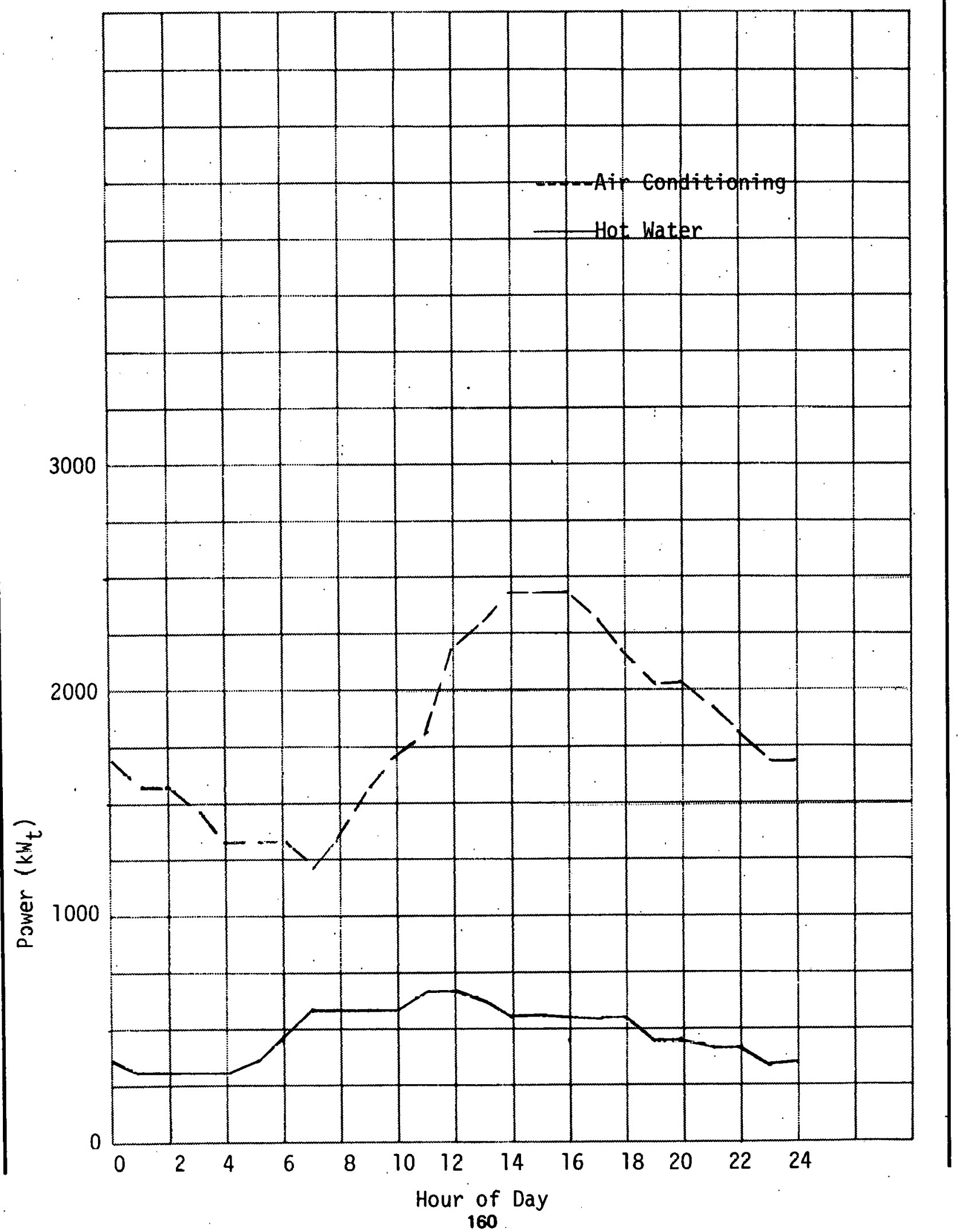


Figure C-8. Typical August Day Demands

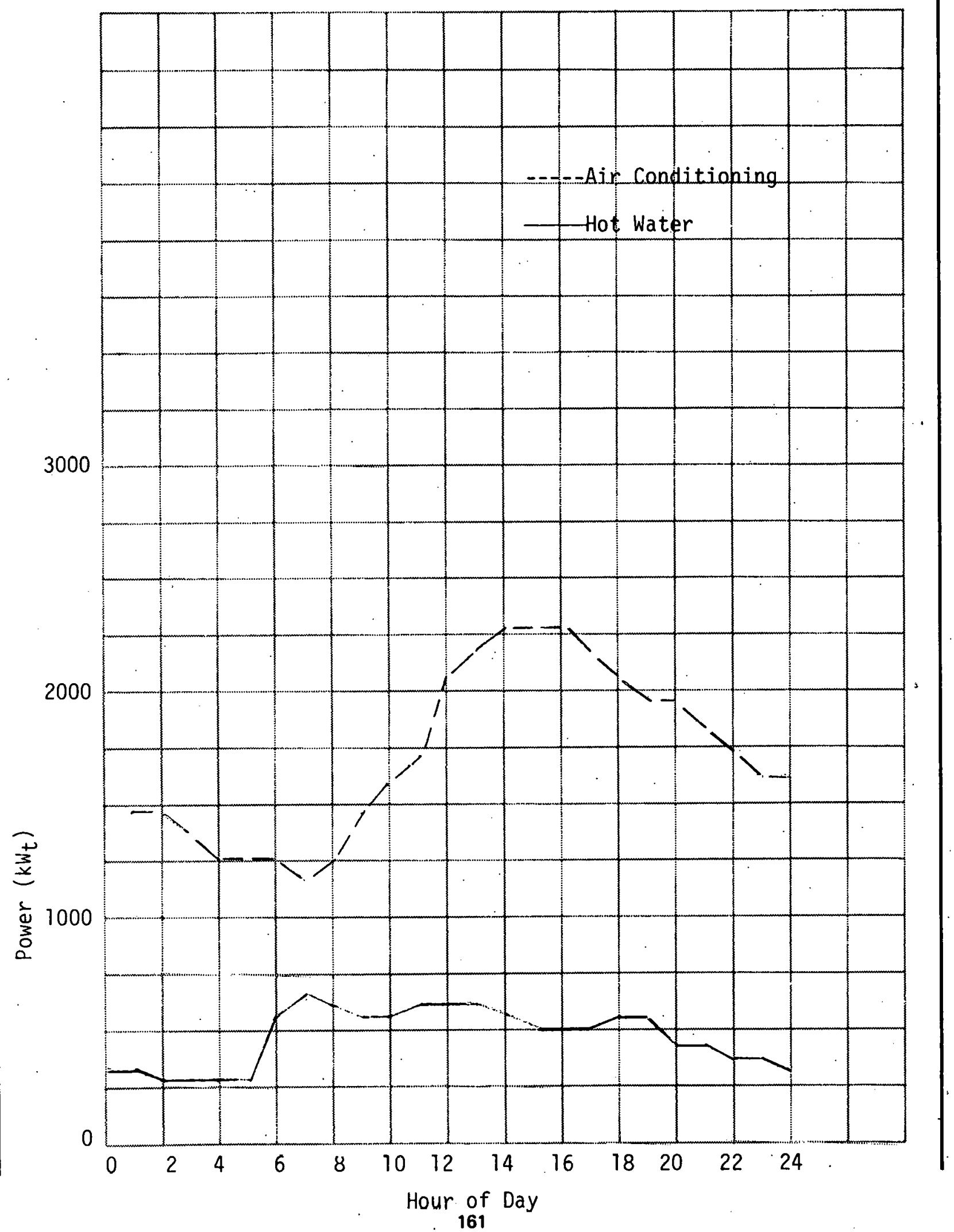


Figure C-9. Typical September Day Demands

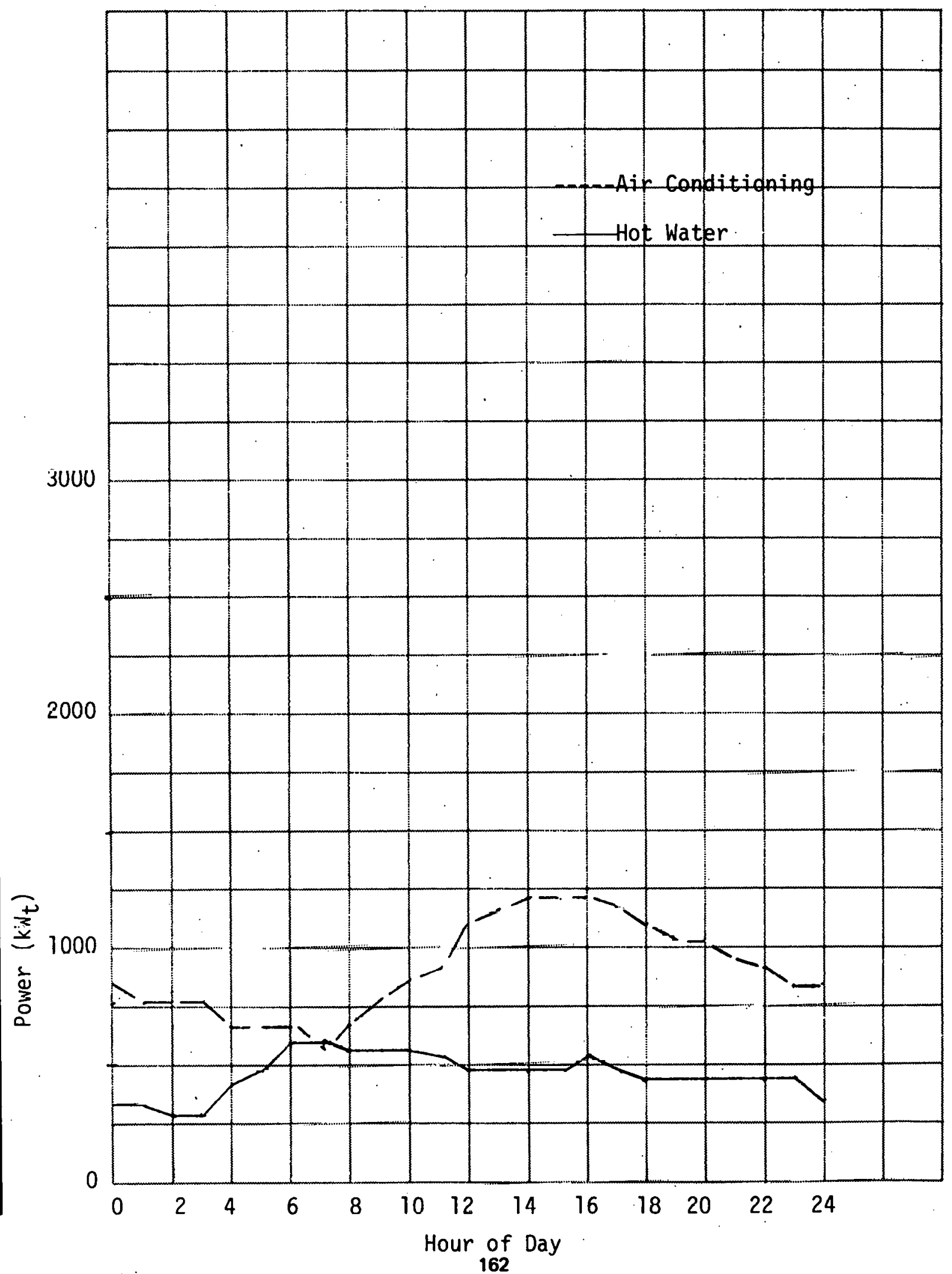


Figure C-10. Typical October Day Demands

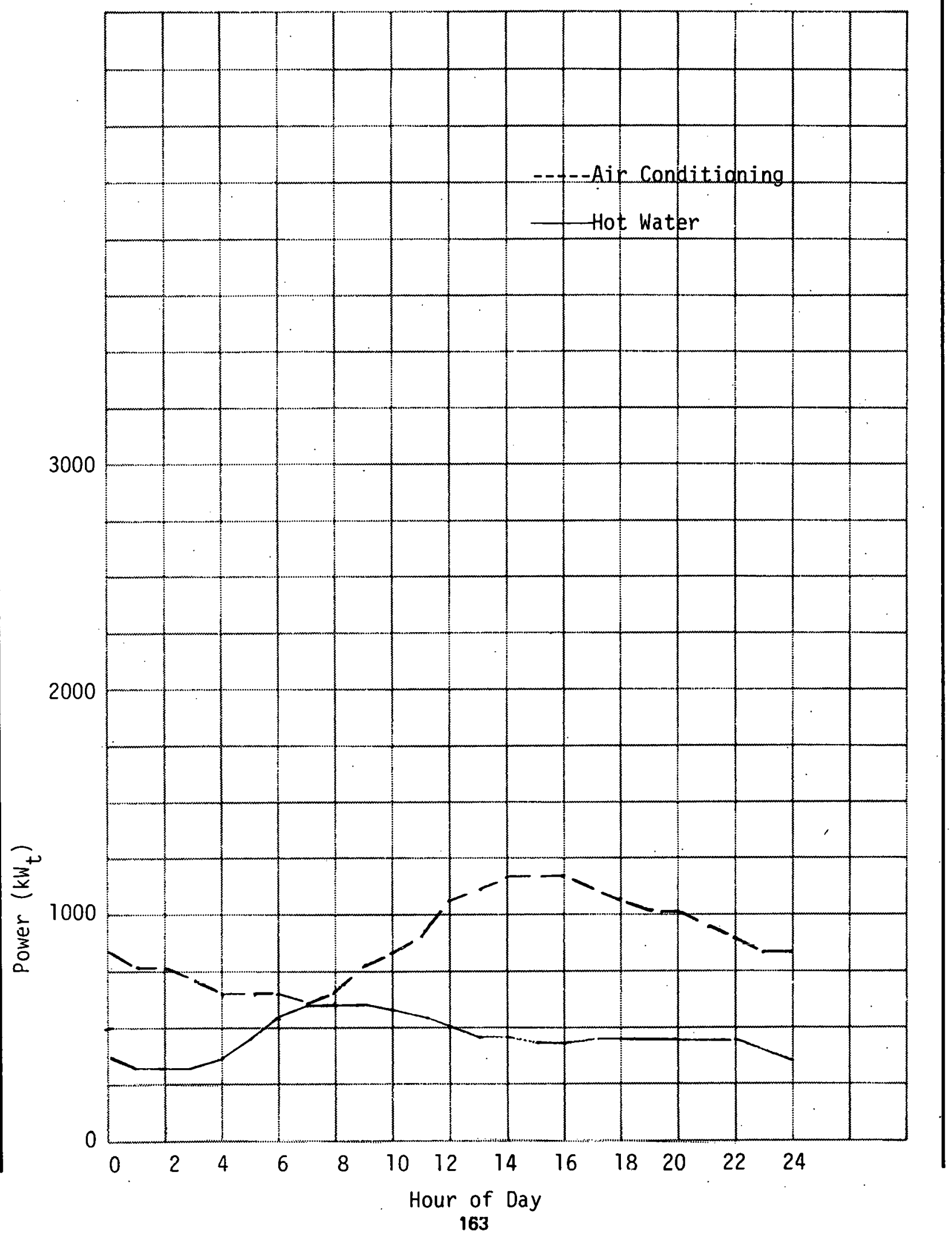


Figure C-11. Typical November Day Demands

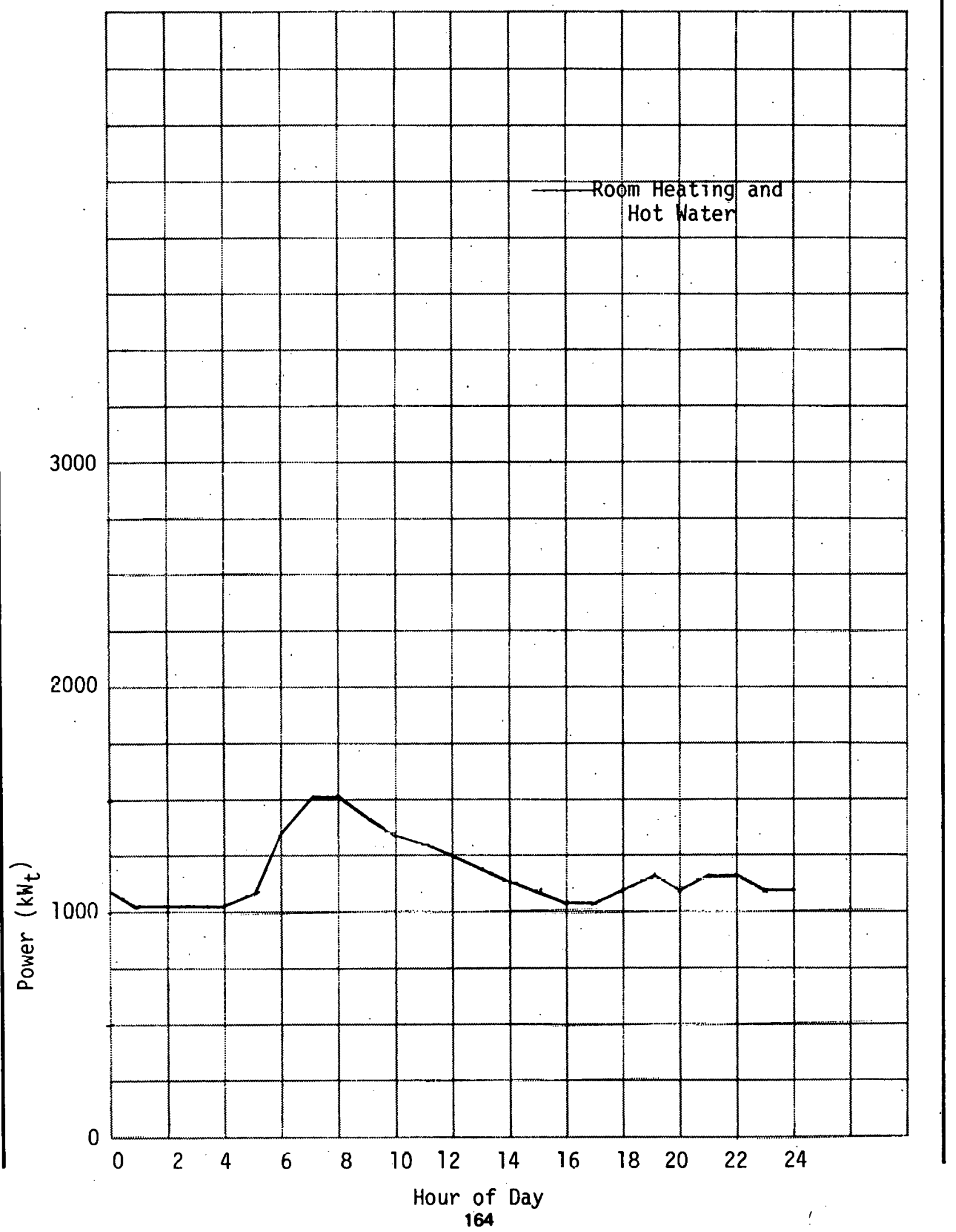


Figure C-12. Typical December Day Demands

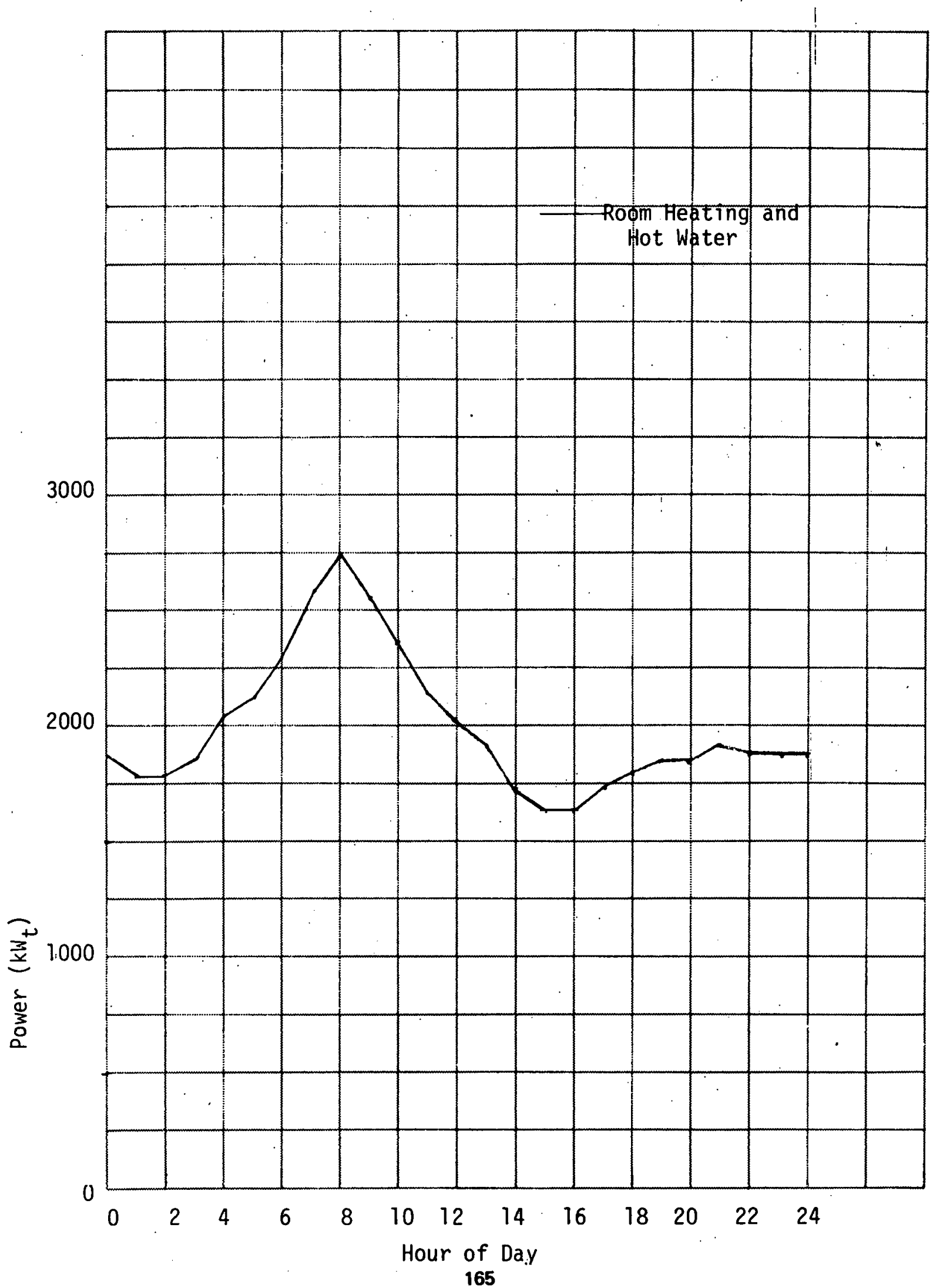


MCDONNELL DOUGLAS ASTRONAUTICS COMPANY-MUNTINGTON BEACM 5301 Bolsa Avenue, Huntington Beach, California 92647 (714) 896-3311 